


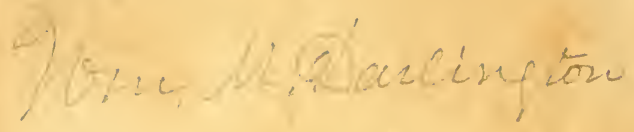









\title{
JOURNAL OF RESEARCHES
}

\author{
INTO THE
}

\section{NA'TURAL HISTORY AND GEOLOGY}

OF THE

COUNTRIES VISITED DURING THE VOYAGE OF H. M. S. BEAGLE

R 0 U N D T H E W 0 R L D,

UNDER THE COMMAND OF CAPT. FITZ ROY, R.N.

BY CHARLES DARWIN, M.A., F.R.S.

I N T W O V O L U M E S.

V O L. I I.

N E W - Y O R K :

HARPER \& BROTHERS, PUBLISHERS, 82 CLIFF STEET.

1846 . 


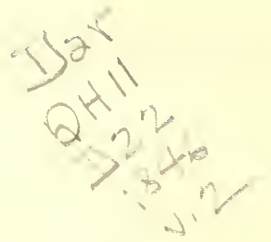




\section{0 N'T E N T' S}

\section{OF THE SECOND VOLUME}

\section{CHAPTER I.}

Chiloe-General Aspect-Boat Excursion-Native IndiansCastro-Tame Fox-Ascend San Pedro-Chonos Archipelago -Peninsula of Tres Montes-Granitic Range-Boat-wrecked Sailors - Low's Harbour-Wild Potato-Formation of Peat - Myopotamus, Otter, and Mice - Cheucau and Barkingbird - Opetiorhynchus-Singular character of OrnithologyPetrels . . . . . . . . . . Page 7

\section{CHAPTER II.}

San Carlos, Chiloe-Osorno in Eruption, contemporaneously with Aconcagua and Coseguina-Ride to Cucao-Impenetrable Forests - Valdivia - Indians - Earthquake - Concepcion-Great Earthquake-Rocks fissured-Appearance of the former Towns -The Sea black and boiling-Direction of the VibrationsStones twisted round-Great Wave-Permanent Elevation of the Land -Area of Volcanic Phenomena - The Connection between the Elevatory and Eruptive Forces-Causes of Earthquakes-Slow Elevation of Mountain-chains . . . 31

\section{CHAPTER III.}

Valparaiso-Portillo Pass-Sagacity of Mules-Mountain Torrents-Mines, how discovered-Proofs of the gradual Elevation of the Cordillera-Effect of Snow on Rocks-Geological Structure of the two main Ranges, their distinct Origin and Upheaval-Great Subsidence-Red Snow - Winds - Pinnacles of Snow-Dry and clear Atmosphere-Electricity-Pampas-Zoology of the opposite Sides of the Andes-Locusts-Great Bugs -Mendoza-Uspallata Pass - Silicified Trees buried as they grew-Incas' Bridge - Badness of the Passes exaggerated-Cumbre-Casuchas-Valparaiso

\section{CHAPTER IV.}

Coast-road to Coquimbo-Great Loads carried by the MinersCoquimbo-Earthquake-Step-formed Terraces-Absence of recent Deposits-Contemporaneousness of the Tertiary Forma- 
tions-Excursion up the Valley-Road to Guasco-DesertsValley of Copiapo-Rain and Earthquakes - HydrophobiaThe Despoblado-Indian Ruins-Probable Change of Climate - River-bed arched by an Earthquake-Cold Gales of WindNoises trom a Hill-Iquique-Salt Alluvium-Nitrate of Soda - Lima-Unhealthy Country-Ruins of Callao, overthrown by an Earthquake-Recent Subsidence-Elevated Shells on San Lorenzo, their Decomposition-Plain with embedded Shells and Fragments of Pottery-Antiquity of the Indian Race

\section{CHAPTER V.}

Page 91

The whole Group volcanic-Number of Craters-Leafless Bushes-Colony at Charles Island-James Island-Salt-lake in Crater - Natural History of the Group - Ornithology, curious Finches-Reptiles-Great Tortoises, Habits of-Marine Lizard, feeds on Sea-weed-Terrestrial Lizard, burrowing Habits, Herbivorous-Importance of Reptiles in the Archipelago-Fish, Shells, Insects-Botany-American Type of Organization-Differences in the Species or Faces on different Islands-Tameness of the Birds-Fear of Man, an acquired Instinct . 138

\section{CHAPTER VI.}

Pass through the Low Archipelago-Tahiti-Aspect-Vegetation on the Mountains-View of Eimeo-Excursion into the Interior-Profound Ravines-Succession of Waterfalls-Number of wild useful Plants-Temperance of the Inhabitants--'Their Moral State-Parliament Convened-New Zealand-Bay of Islands-Hippahs-Excursion to Waimate-Missionary Establishment-English Weeds now run wild-Waiomio-Funeral of a New Zealand Woman-Sail for Australia. . . 176

\section{CHAPTER VII.}

Sydney-Excursion to Bathurst-A spect of the Woods-Party of Natives-Gradual Extinction of the Aborigines-Infection generated by associated Men in Health-Blue Mountains-View of the grand gulf-like Valleys-Their Origin and FormationBathurst, general Civility of the lower Orders-State of Society-Van Diemen's Land-Hobart Town-Aborigines all banished-Mount Wellington-King George's Sound-Cheerless Aspect of the Country-Bald Head, calcareous Casts of Branches of Trees-Party of Natives-Leave Australia . . 214

\section{CHAPTER VIII.}

Keeling Island-Singular Appearance-Scanty Flora-Transport of Seeds-Birds and Insects-Ebbing and Flowing SpringsFields of dead Coral-Stones transported in the Roots of Trees 
-Great Crab-Stinging Corals-Coral-eating Fish-Coral Formations-Lagoon Islands or Atolls-Depth at which reef-building Corals call live-Vast Areas interspersed with low Coral Islands-Subsidence of their Foundations-Barrier ReefsFringing Reefs-Conversion of Fringing Reefs into Barrier Reets and into Atolls-Evidence of Changes in Level-Breaches in Barrier Reefs-Maldiva Atolls ; their peculiar Structure- Dead and submerged Reefs-Areas of Subsidence and Elevation-Distribution of Volcanoes-Subsidence Slow, and vast in Amount

Page 242

\section{CHAPTER IX.}

Mauritius, beautiful Appearance of-Great crateriform Ring of Mountains-Hindoos-St. Helena-History of the Changes in the Vegetation-Cause of the Extinction of Land-shells-Ascension-Variation in the imported Rats-Volcanic BombsBeds of Infusoria-Bahia-Brazil-Splendour of tropical Scenery-Pernambuco-Singular Reef-Slavery-Return to England-Retrospect on our Voyage. $. \quad . \quad . \quad 281$

INDEX . . . . . . . . . . . . . 313 



\section{J O U R N A L.}

\section{CHAPTER I.}

Chiloe-General Aspect-Boat Fxcursion - Native IndiansCastro-Tame Fox-Ascend San Pedro-Chonos Archipelago -Peninsula of Tres Montes-Granitic Range-Boat-wrecked Sailors - Low's Harbour-Wild Potato-Formation of Peat - Myopotamus, Otter, and Mice-Cheucau and Barking. bird - Opetiorhynchus-Singular character of OrnithologyPetrels.

\section{CHILOE AND CHONOS ISLANDS.}

November 10th.-The Beagle sailed from Valparaiso to the south, for the purpose of surveying the southern part of Chile, the island of Chiloe, and the broken land called the Chonos Archipelago, as far south as the peninsula of Tres Montes. On the 21st we anchored in the bay of S. Carlos, the capital of Chiloe.

This island is about ninety miles long, with a breadth of rather less than thirty. The land is hilly, but not mountainous, and is covered by one great forest, except where a few green patches have been cleared round the thatched cottages. From a distance the view somewhat resembles that of Tierra del Fuego; but the woods, when seen nearer, are incomparably more beautiful. Many kinds of fine evergreen trees, and plants with a tropical character, here take the place of the gloomy beech of the southern shores. In winter the climate is detestable, and in summer it is only a little better. I should think there are few parts of the world, within the temperate regions, where so much rain falls. The winds are very 
boisterous, and the sky almost always clouded : to have a week of fine weather is something wonderful. It is even difficult to get a single glimpse of the Cordillera : during our first visit, once only the volcano of Osorno stood out in bold relief, and that was before sunrise; it was curious to watch, as the sun rose, the outline gradually fading away in the glare of the eastern sky.

The inhabitants, from their complexion and low stature, appear to have three fourths of Indian blood in their veins. They are an humble, quiet, industrious set of men. Although the fertile soil, resulting from the decomposition of the volcanic rocks, supports a rank vegetation, yet the climate is not favourable to any production which requires much sunshine to ripen it. There is very little pasture for the larger quadrupeds; and in consequence, the staple articles of food are pigs, potatoes, and fish. The people all dress in strong woollen garments, which each family makes for itself, and dyes with indigo of a dark blue colour. The arts, however, are in the rudest state, as may be seen in their strange fashion of ploughing, their method of spinning, grinding corn, and in the construction of their boats. The forests are so impenetrable, that the land is nowhere cultivated except near the coast and on the adjoining islets. Even where paths exist, they are scarcely passable from the soft and swampy state of the soil. The inhabitants, like those of Tierra del Fuego, move about chiefly on the beach or in boats. Although with plenty to eat, the people are very poor; there is no demand for labour, and consequently the lower orders cannot scrape together money sufficient to purchase even the smallest luxuries. There is also a great deficiency of a circulating medium. I have seen a man bringing on his back 
a bag of charcoal with which to buy some trifle, and another carrying a plank to exchange for a bottle of wine. Hence every tradesman must also be a merchant, and again sell the goods which he takes in exchange.

November 24th.-The yawl and whale-boat were sent under the command of $\mathrm{Mr}$. (now Captain) Sulivan, to survey the eastern or inland coast of Chiloe, and with orders to meet the Beagle at the southern extremity of the island, to which point she would proceed by the outside, so as thus to circumnavigate the whole. I accompanied this expedition; but, instead of going in the boats the first day, I hired horses to take me to Chacao, at the northern extremity of the island. The road followed the coast, every now and then crossing promontories covered by fine forests. In these shaded paths it is absolutely necessary that the whole road should be made of logs of wood, which are squared and placed by the side of each other. From the rays of the sun never penetrating the evergreen foliage, the ground is so damp and soft, that, except by this means, neither man nor horse would be able to pass along. I arrived at the village of Chacao shortly after the tents belonging to the boats were pitched for the night.

The land in this neighbourhood has been extensively cleared, and there were many quiet and most picturesque nooks in the forest. Chacao was formerly the principal port in the island; but many vessels having been lost, owing to the dangerous currents and rocks in the straits, the Spanish government burned the church, and thus arbitrarily compelled the greater number of inhabitants to migrate to S. Carlos. We had not long bivouacked before the barefooted son of the governor came down to reconnoitre us. Seeing the English flag 
hoisted at the yawl's mast-head, he asked, with the utmost indifference, whether it was always to fly at Chacao. In several places, the inhabitants were much astonished at the appearance of men-of-war's boats, and hoped and believed it was the forerunner of a Spanish fleet, coming to recover the island from the patriot government of Chile. All the men in power, however, had been informed of our intended visit, and were exceedingly civil. While we were eating our supper, the governor paid us a visit. Hẻ had been a lieutenant-colonel in the Spanish service, but now was miserably poor. He gave us two sheep, and accepted in return two cotton handkerchiefs, some brass trinkets, and a little tobacco.

25th.-Torrents of rain: we managed, however, to run down the coast as far as Huapi-lenou. The whole of this eastern side of Chiloe has one aspect: it is a plain, broken by valleys and divided into little islands, and the whole thickly covered with one impervious blackish-green forest. On the margins there are some cleared spaces, surrounding the high-roofed cottages.

$26 t h$.-The day rose splendidly clear. The volcano of Osorno was spouting out volumes of smoke. This most beautiful mountain, formed like a perfect cone, and white with snow, stands out in front of the Cordillera. Another great volcano, with a saddle-shaped summit, also emitted from its imniense crater little jets of steam. Subsequently we saw the lofty-peaked Corcovado-well deserving the name of " el famoso Corcovado." Thus we beheld, from one point of view, three great active volcanoes, each about seven thousand feet high. In addition to this, far to the south, there were other lofty cones covered with snow, which, although not known to be active, must be in their 
origin volcanic. The line of the Andes is not, in this neighbourhood, nearly so elevated as in Chile; neither does it appear to form so perfect a barrier between the regions of the earth. This great range, although running in a straight north and south line, owing to an optical deception, always appeared more or less curved; for the lines drawn from each peak to the beholder's eye necessarily converged like the radii of a semicircle, and as it was not possible (owing to the clearness of the atmosphere and the absence of all intermediate objects) to judge how far distant the farthest peaks were off, they appeared to stand in a flattish semicircle. Landing at midday, we saw a family of pure Indian extraction. The father was singularly like York Minster ; and some of the younger boys, with their ruddy complexions, might have been mistaken for Pampas Indians. Everything I have seen convinces me of the close connexion of the different American tribes, who nevertheless speak distinct languages. This party could muster but little Spanish, and talked to each other in their own tongue. It is a pleasant thing to see the aborigines advanced to the same degree of civilization, however low that may be, which their white conquerors have attained. More to the south we saw many pure Indians: indeed, all the inhabitants of some of the islets retain their Indian surnames. In the census of 1832, there were in Chiloe and its dependencies forty-two thousand souls : the greater number of these appear to be of mixed blood. Eleven thousand retain their Indian surnames, but it is probable that not nearly all of these are of a pure breed. Their manner of life is the same with that of the other poor inhabitants, and they are all Christians; but it is said that they yet retain some strange superstitious ceremonies, and 
that they pretend to hold communication with the devil in certain caves. Formerly, every one convicted of this offence was sent to the Inquisition at Lima. Many of the inhabitants who are not included in the eleven thousand with Indian surnames cannot be distinguished by their appearance from Indians. Gomez, the governor of Lemuy, is descended from noblemen of Spain on both sides; but by constant intermarriages with the natives the present man is an Indian. On the other hand, the governor of Quinchao boasts much of his purelykept Spanish blood.

We reached at night a beautiful little cove north of the island of Caucahue. The people here complained of want of land. This is partly owing to their own negligence in not clearing the woods, and partly to restrictions by the government, which makes it necessary, before buying ever so small a piece, to pay two shillings to the surveyor for measuring each quadra ( 150 yards square), together with whatever price he fixes for the value of the land. After his valuation, the land must be put up three times to auction, and if no one bids more, the purchaser can have it at that rate. All these exactions must be a serious check to clearing the ground, where the inhabitants are so extremely poor. In most countries, forests are removed without much difficulty by the aid of fire; but in Chiloe, from the damp nature of the climate and the sort of trees, it is necessary first to cut them down. This is a heavy drawback to the prosperity of Chiloe. In the time of the Spaniards the Indians could not hold land; and a family, after having cleared a piece of ground, might be driven away, and the property seized by the government. The Chilian authorities are now performing an act of justice by making retribution to these poor Indians, 
giving to each man, according to his grade of life, a certain portion of land. The value of uncleared ground is very little. The government gave $\mathrm{Mr}$. Douglas (the present surveyor, who informed me of these circumstances) eight and a half square miles of forest near San Carlos in lieu of a debt; and this he sold for 350 dollars, or about $£ 70$ sterling.

The two succeeding days were fine, and at night we reached the island of Quinchao. This neighbourhood is the most cultivated part of the Archipelago ; for a broad strip of land on the coast of the main island, as well as on many of the smaller adjoining ones, is almost completely cleared. Some of the farm-houses seemed very comfortable. I was curious to ascertain how rich any of these people might be, but Mr. Douglas says that no one can be considered as possessing a regular income. One of the richest landowners might possibly accumulate, in a long industrious life, as much as $£ 1000$ sterling; but should this happen, it would all be stowed away in some secret corner, for it is the custom of almost every family to have a jar or treasure-chest buried in the ground.

November 30th.-Early on Sunday morning we reached Castro, the ancient capital of Chiloe, but now a most forlorn and deserted place. The usual quadrangular arrangement of Spanish towns could be traced, but the streets and plaza were coated with fine green turf, on which sheep were browsing. The church, which stands in the middle, is entirely built of plank, and has a picturesque and venerable appearance. The poverty of the place may be conceived from the fact, that although containing some hundreds of inhabitants, one of our party was unable anywhere to purchase either a pound of sugar or an ordinary knife. No individual posII.-B 
sessed either a watch or a clock; and an old man, who was supposed to have a good idea of time, was employed to strike the church bell by guess. The arrival of our boats was a rare event in this quiet, retired corner of the world, and nearly all the inhabitants came down to the beach to see us pitch our tents. They were very civil, and offered us a house; and one man even sent us a cask of cider as a present. In the afternoon we paid our respects to the governor-a quiet old man, who, in his appearance and manner of life, was scarcely superior to an English cottager. At night heavy rain set in, which was hardly sufficient to drive away from our tents the large circle of lookers on. An Indian family, who had come to trade in a canoe from Caylen, bivouacked near us. They had no shelter during the rain. In the morning I asked a young Indian, who was wet to the skin, how he had passed the night. He seemed perfectly content, and answered, "Muy bien, señor."

December 1st.-We steered for the island of Lemuy. I was anxious to examine a reported coal-mine, which turned out to be lignite of little value, in the sandstone (probably of an ancient tertiary epoch) of which these islands are composed. When we reached Lemuy we had much difficulty in finding any place to pitch our tents, for it was spring-tide, and the land was wooded down to the water's edge. In a short time we were surrounded by a large group of the nearly pure Indian inhabitants. They were much surprised at our arrival, and said, one to the other, "This is the reason we have seen so many parrots lately; the cheucau (an odd, red-breasted little bird, which inhabits the thick forest, and utters very peculiar noises) has not cried 'beware' for nothing." 'They were soon anxious for barter. Money was scarcely 
worth anything, but their eagerness for tobacco was something quite extraordinary. After tobacco, indigo came next in value; then capsicum, old clothes, and gunpowder. The latter article was required for a very innocent purpose : each parish has a public musket, and the gunpowder was wanted for making a noise on their saint or feast days.

The people here live chiefly on shell-fish and potatoes. At certain seasons they catch also, in "corrales," or hedges under water, many fish which are left on the mud-banks as the tide falls. They occasionally possess fowls, sheep, goats, pigs, horses, and cattle ; the order in which they are here mentioned expressing their respective numbers. I never saw anything more obliging and humble than the manners of these people. They generally began with stating that they were poor natives of the place, and not Spaniards, and that they were in sad want of tobacco and other comforts. At Caylen, the most southern island, the sailors bought with a stick of tobacco, of the value of three halfpence, two fowls, one of which, the Indian stated, had skin between its toes, and turned out to be a fine duck; and with some cotton handkerchiefs, worth three shillings, three sheep and a large bunch of onions were procured. The yawl at this place was anchored some way from the shore, and we had fears for her safety from robbers during the night. Our pilot, Mr. Douglas, accordingly told the constable of the district that we always placed sentinels with loaded arms; and not understanding Spanish, if we saw any person in the dark, we should assuredly shoot him. The constable, with much humility, agreed to the perfect propriety of this arrangement, and promised us that no one should stir out of his house during that night. 
During the four succeeding days we continued sailing southward. The general features of the country remained the same, but it was much less thickly inhabited. On the large island of Tanqui there was scarcely one cleared spot, the trees on every side extending their branches over the seabeach. I one day noticed, growing on the sandstone cliffs, some very fine plants of the panke (Gunnera scabra), which somewhat resembles the rhubarb on a gigantic scale. The inhabitants eat the stalks, which are subacid, and tan leather with the roots, and prepare a black dye from them. The leaf is nearly circular, but deeply indented on its margin. I measured one which was nearly eight feet in diameter, and therefore no less than twenty-four in circumference! The stalk is rather more than a yard high, and each plant sends out four or five of these enormous leaves, presenting together a very noble appearance.

December 6th.-We reached Caylen, called "el fin del Cristiandad." In the morning we stopped for a few minutes at a house on the northern end of Laylec, which was the extreme point of South American Christendom, and a miserable hovel it was. The latitude is $43^{\circ} 10^{\prime}$, which is two degrees farther south than the Rio Negro on the Atlantic coast. These extreme Christians were very poor, and, under the plea of their situation, begged for some tobacco. As a proof of the poverty of these Indians, I may mention, that shortly before this we had met a man who had travelled three days and a half on foot, and had as many to return, for the sake of recovering the value of a small axe and a few fish. How very difficult it must be to buy the smallest article, when such trouble is taken to recover so small a debt!

In the evening we reached the island of San 
Pedro, where we found the Beagle at anchor. In doubling the point, two of the officers landed to take a round of angles with the theodolite. A fox (Canis fulvipes), of a kind said to be peculiar to the island, and very rare in it, and which is a new species, was sitting on the rocks. He was so intently'absorbed in watching the work of the offcers, that I was able, by quietly walking up behind, to knock him on the head with my geological hammer. This fox, more curious or more scientific, but less wise, than the generality of his brethren, is now mounted in the museum of the Zoological Society.

We stayed three days in this harbour, on one of which Captain Fitz Roy, with a party, attempted to ascend to the summit of San Pedro. The woods here had rather a different appearance from those on the northern part of the island. The rock, also, being micaceous slate, there was no beach, but the steep sides dipped directly beneath the water. The general aspect in consequence was more like that of Tierra del Fuego than of Chiloe. In vain we tried to gain the summit: the forest was so impenetrable, that no one who has not beheld it can imagine so entangled a mass of dying and dead trunks. I am sure that often, for more than ten minutes together, our feet never tou ched the ground, and we were frequently ten or fifteen feet above it, so that the seamen, as a joke, called out the soundings. At other times we crept one after another on our hands and knees under the rotten trunks. In the lower part of the mountain, noble trees of the Winter's Bark, and a laurel like the sassafras, with fragrant leaves, and others, the names of which I do not know, were matted together by a trailing bamboo or cane. Here we were more like fishes struggling in a net than any other aniII. 
mal. On the higher parts, brushwood takes the place of larger trees, with here and there a red cedar or an alerce pine. I was also pleased to see, at an elevation of a little less than 1000 feet, our old friend the southern beech. They were, however, poor stunted trees; and I should think that this must be nearly their northern limit. We ultimately gave up the attempt in despair.

December 10th.-The yawl and whale-boat, with Mr. Sulivan, proceeded on their survey, but I remained on board the Beagle, which the next day left San Pedro for the southward. On the 13th we ran into an opening in the southern part of Guayatecas, or the Chonos Archipelago; and it was fortunate we did so, for on the following day a storm, worthy of Tierra del Fuego, raged with great fury. White massive clouds were piled up against a dark-blue sky, and across them black ragged sheets of vapour were rapidly driven. The successive mountain ranges appeared like dim shadows, and the setting sun cast on the woodland a yellow gleam, much like that produced by the flame of spirits of wine. The water was white with the flying spray, and the wind lulled and roared again through the rigging: it was an ominous, sublime scene. During a few minutes there was a bright rainbow, and it was curious to observe the effect of the spray, which, being carried along the surface of the water, changed the ordinary semicircle into a circle, a band of prismatic colours being continued, from both feet of the common arch across the bay, close to the vessel's side, thus forming a distorted but very nearly entire ring.

We stayed here three days. The weather continued bad, but this did not much signify, for the surface of the land in all these islands is all but impassable. The coast is so very rugged, that to at- 
tempt to walk in that direction requires continued scrambling up and down over the sharp rocks of mica-slate; and as for the woods, our faces, hands, and shin-bones all bore witness to the maltreatment we received in merely attempting to penetrate their forbidden recesses.

December $18 t h .-W e$ stood out to sea. On the 20 th we bade farewell to the south, and, with a fair wind, turned the ship's head northward. From Cape Tres Montes we sailed pleasantly along the lofty weather-beaten coast, which is remarkable for the bold outline of its hills, and the thick covering of forest even on the almost precipitous flanks. The next day a harbour was discovered, which, on this dangerous coast, might be of great service to a distressed vessel. It can easily be recognised by a hill, 1600 feet high, which is even more perfectly conical than the famous sugar-loaf at Rio de Janeiro. The next day, after anchoring, I succeeded in reaching the summit of this hill. It was a laborious undertaking, for the sides were so steep that in some parts it was necessary to use the trees as ladders. There were also several extensive brakes of the Fuchsia, covered with its beautiful drooping flowers, but very difficult to crawl through. In these wild countries it gives much delight to gain the summit of any mountain. There is an indefinite expectation of seeing something very strange, which, however often it may be balked, never failed with me to recur on each successive attempt. Every one must know the feeling of triumph and pride which a grand view from a height communicates to the mind. In these little-frequented countries, there is also joined to it some vanity, that you, perhaps, are the first man who ever stood on this pinnacle or admired this view.

A strong desire is always felt to ascertain wheth- 
er any human being has previously visited an unfrequented spot. A bit of wood, with a nail in it, is picked up and studied as if it were covered with hieroglyphics. Possessed with this feeling, I was much interested by finding, on a wild part of the coast, a bed, made of grass, beneath a ledge of rock. Close by it there had been a fire, and the man had used an axe. The fire, bed, and situation showed the dexterity of an Indian, but he could scarcely have been an Indian, for the race is in this part extinct, owing to the Catholic desire of making at one blow Christians and slaves. I had at the time some misgivings that the solitary man who had made his bed on this wild spot must have been some poor shipwrecked sailor, who, in trying to travel up the coast, had here laid himself down for his dreary night.

December 2sth.-The weather continued very bad, but it at last permitted us to proceed with the survey. The time hung heavy on our hands, as it always did when we were delayed from day to day by successive gales of wind. In the evening another harbour was discovered, where we anchored. Directly afterwards a man was seen waving his shirt, and a boat was sent which brought back two seamen. A party of six had run away from an American whaling vessel, and had landed a little to the southward in a boat, which was shortly afterwards knocked to pieces by the surf. They had now been wandering up and down the coast for fifteen months, without knowing which way to go, or where they were. What a singular piece of good fortune it was that this harbour was now discovered! Had it not been for this one chance, they might have wandered till they had grown old men, and at last have perished on this wild coast. Their sufferings had been very great, and one of 
their party had lost his life by falling from the cliffs. They were sometimes obliged to separate in search of food, and this explained the bed of the solitary man. Considering what they had undergone, I think they had kept a very good reckoning of time, for they had lost only four days.

December 30th.-We anchored in a snug little cove at the foot of some high hills, near the northern extremity of Tres Montes. After breakfast the next morning, a party ascended one of these mountains, which was 2400 feet high. The scenery was remarkable. The chief part of the range was composed of grand, solid, abrupt masses of granite, which appeared as if they had been coeval with the beginning of the world. The granite was capped with mica-slate, and this, in the lapse of ages, had been worm into strange finger-shaped points. These two formations, thus differing in their outlines, agree in being almost destitute of vegetation. This barrenness had to our eyes a strange appearance, from having been so long accustomed to the sight of an almost universal forest of dark-green trees. I took much delight in examining the structure of these mountains. The complicated and lofty ranges bore a noble aspect of durability-equally profitless, however, to man and to all other animals. Granite, to the geologist, is classic ground: from its wide-spread limits, and its beautiful and compact texture, few rocks have been more anciently recognised. Granite has given rise, perhaps, to more discussion concerning its origin than any other formation. We generally see it constituting the fundamental rock, ard, however formed, we know it is the deepest layer, in the crust of this globe, to which man has penetrated. The limit of man's knowledge, in any subject, possesses a high interest, which is perhaps increased by its close neighbourhood to the realms of imagination. 
January 1st, 1835.-The new year is ushered in with the ceremonies proper to it in these regions. She lays out no false hopes: a heavy northwestern gale, with steady rain, bespeaks the rising year. Thank God! we are not destined here to see the end of it, but hope then to be in the Pacific Ocean, where a blue sky tells one there is a heaven-a something beyond the clouds above our heads.

The northwest winds prevailing for the next four days, we only managed to cross a great bay, and then anchored in another secure harbour. I accompanied the Captain in a boat to the head of a deep creek. On the way, the number of seals which we saw was quite astonishing: every bit of flat rock, and parts of the beach, were covered with them. They appeared to be of a loving disposition, and lay huddled together, fast asleep, like so many pigs; but even pigs would have been ashamed of their dirt, and of the foul smell which came from them. Each herd was watched by the patient but inauspicious eyes of the turkey-buzzard. This disgusting bird, with its bald, scarlet head, formed to wallow in putridity, is very common on the west coast, and their attendance on the seals shows on what they rely for their food. We found the water (probably only that of the surface) nearly fresh: this was caused by the number of torrents which, in the form of cascades, came tumbling over the bold granite mountains into the sea. The fresh water attracts the fish, and these bring many terns, gulls, and two kinds of cormorant. We saw also a pair of the beautiful black-necked swans, and several small sea-otters, the fur of which is held in such high estimation. In returning, we were again amused by the impetuous manner in which the heap of seals, old and young, tumbled into the water as the boat passed. They did not remain long under water, 
but, rising, followed us with outstretched necks, expressing great wonder and curiosity.

7th.- Having run up the coast, we anchored near the northern end of the Chonos Archipelago, in Low's Harbour, where we remained a week. The islands were here, as in Chiloe, composed of a stratified, soft, litteral deposit, and the vogetation, in consequence, was beautifully luxuriant. The woods came down to the sea-beach just in the manner of an evergreen shrubbery over a gravel walk. We also enjoyed from the anchorage a splendid view of four great snowy cones of the Cordillera, including " el famoso Corcovado:" the range itself had in this latitude so little height, that few parts of it appeared above the tops of the neighbouring islets. We found here a party of five men from Caylen, "el fin del Cristiandad," who had most adventurously crossed, in their miserable boat-canoe, for the purpose of fishing, the open space of sea which separates Chonos from Chiloe. These islands will, in all probability, in a short time become peopled like those adjoining the coast of Chiloe.

The wild potato grows on these islands in great abundance, on the sandy, shelly soil near the seabeach. The tallest plant was four feet in height. The tubers were generally small, but I found one, of an oval shape, two inches in diameter: they resembled in every respect, and had the same smell as English potatoes; but when boiled they shrunk much, and were watery and insipid, without any bitter taste. They are undoubtedly here indigenous: they grow as far south, according to Mr. Low, as lat. $50^{\circ}$, and are called Aquinas by the wild Indians of that part: the Chilotan Indians have a different name for them. Professor Henslow, who has examined the dried specimens which 
I brought home, says that they are the same with those described by Mr. Sabine* from Valparaiso, but that they form a variety which by some botanists has been considered as specifically distinct. It is remarkable that the same plant should be found on the sterile mountains of central Chile, where a drop of rain does not fall for more than six months, and within the damp forests of these southern islands.

In the central parts of the Chonos Archipelago (lat. $45^{\circ}$ ) the forest has very much the same character with that along the whole west coast for 600 miles southward to Cape Horn. The arborescent grass of Chiloe is not found here, while the beech of Tierra del Fuego grows to a good size, and forms a considerable proportion of the wood not, however, in the same exclusive manner as it does farther southward. Cryptogamic plants here find a most congenial climate. In the Strait of Magellan, as I have before remarked, the country appears too cold and wet to allow of their arriving at perfection; but in these islands, within the forest, the number of species, and great abundance of mosses, lichens, and small ferns, is quite extraordinary. $\dagger$ In Tierra del Fuego trees grow only on the hill-sides, every level piece of land being invariably covered by a thick bed of peat; but in Chiloe flat land supports the most luxuriant forests.

* Horticultural Transact., vol. v., p. 249. Mr. Caldcleugh sent home two tubers, which, being well manured, even the first season produced numerous potatoes and an abundance of leaves. See Humboldt's interesting discussion on this plant, which it appears was unknown in Mexico, in Polit. Essay on New Spain, book iv., chap. ix.

+ By sweeping with my insect-net, I procured from these situations a considerable number of minute insects, of the family of Staphylinidæ, and others allied to Pselaphus, and minute $\mathrm{Hy}$ menoptera. But the most characteristic family in number, both of individuals and species, throughout the more open parts of Chiloe and Chonos, is that of the Telephoridæ. 
Here, within the Chonos Archipelago, the nature of the climate more closely approaches that of $\mathrm{Ti}$ erra del Fuego than that of northern Chiloe; for every patch of level ground is covered by two species of plants (Astelia pumila and Donatia magellanica), which by their joint decay compose a thick bed of elastic peat.

In Tierra del Fuego, above the region of woodland, the former of these eminently sociable plants is the chief agent in the production of peat. Fresh leaves are always succeeding one to the other round the central tap-root; the lower ones soon decay, and in tracing a root downwards in the peat, the leaves, yet holding their place, can be observed passing through every stage of decomposition, till the whole becomes blended in one confused mass. The Astelia is assisted by a few other plants-here and there a small creeping Myrtus (M. nummularia), with a woody stem like our cranberry, and with a sweet berry-an Empetrum (E. rubrum), like our heath-a rush (Juncus grandiflorus), are nearly the only ones that grow on the swampy surface. These plants, though possessing a very close general resemblance to the English species of the same genera, are different. In the more level parts of the country, the surface of the peat is broken up into little pools of water, which stand at different heights, and appear as if artificially excavated. Small streams of water, flowing under ground, complete the disorganization of the vegetable matter, and consolidate the whole.

The climate of the southern part of America appears particularly favourable to the production of peat. In the Falkland Islands almost every kind of plant, even the coarse grass which covers the whole surface of the land, becomes converted inte, this substance: scarcely any situation checks its II.-C 
growth; some of the beds are as much as twelve feet thick, and the lower part becomes so solid, when dry, that it will hardly burn. Although every plant lends its aid, yet in most parts the Astelia is the most efficient. It is rather a singular circumstance, as being so very different from what occurs in Europe, that I nowhere saw moss forming by its decay any portion of the peat in South America. With respect to the northern limit at which the climate allows of that peculiar kind of slow decomposition which is necessary for its production, I believe that in Chiloe (lat. $41^{\circ}$ to $42^{\circ}$ ), although there is much swampy ground, no wellcharacterized peat occurs; but in the Chonos Islands, three degrees farther southward, we have seen that it is abundant. On the eastern coast, in La Plata (lat. $35^{\circ}$ ), I was told by a Spanish resident, who had visited Ireland, that he had often sought for this substance, but had never been able to find any. He showed me, as the nearest approach to it which he had discovered, a black, peaty soil so penetrated with roots as to allow of an extremely slow and imperfect combustion.

The zoology of these broken islets of the Chonos Archipelago is, as might have been expected, very poor. Of quadrupeds two aquatic kinds are common. The Myopotamus Coypus (like a beaver, but with a round tail) is well known from its fine fur, which is an object of trade throughout the tributaries of La Plata. It here, however, exclusively frequents salt water; which same eircumstance has been mentioned as sometimes occurring with the great rodent, the Capybara. A small seaotter is very numerous : this animal does not feed exclusively on fish, but, like the seals, draws a large supply from a small red crab, which swims in shoals 
near the surface of the water. Mr. Bynoe saw one in Tierra del Fuego eating a cuttle-fish; and at Low's Harbour, another was killed in the act of carrying to its hole a large volute shell. At one place I caught in a trap a singular little mouse (M. brachiotis): it appeared common on several of the islets, but the Chilotans at Low's Harbour said that it was not found in all. What a succession of chances,* or what changes of level must have been brought into play, thus to spread these small animals throughout this broken archipelago!

In all parts of Chiloe and Chonos, two very strange birds occur, which are allied to, and replace, the Turco and Tapacolo of central Chile. One is called by the inhabitants "Cheucau" (Pteroptochos rubecula): it frequents the most gloomy and retired spots within the damp forests. Sometimes, although its cry may be heard close at hand, let a person watch ever so attentively, he will not see the cheucau; at other times, let him stand mo tionless, and the red-breasted little bird will approach within a few feet in the most familiar manner. It then busily hops about the entangled mass of rotting canes and branches, with its little tail cocked upwards. The cheucau is held in superstitious fear by the Chilotans, on account of its strange and varied cries. There are three very distinct cries: one is called "chiduco," and is an omen of good; another, "huitreu," which is extremely unfavourable; and a third, which I have forgotten. These words are given in imitation of the noises; and the natives are in some things absolutely governed by them. The Chilotans assu-

* It is said that some rapacious birds bring their prey alive to their nests. If so, in the course of centuries, every now and then, one might escape from the young birds. Some such agency is necessary to account for the distribution of the smaller gnawing animals on islands not very near each other. 
redly have chosen a most comical little creature for their prophet. An allied species, but rather larger, is called by the natives "Guid-guid" (Pteroptochos Tarnii), and by the English the barkingbird. This latter name is well given, for I defy any one at first to feel certain that a small dog is not yelping somewhere in the forest. Just as with the cheucau, a person will sometimes hear the bark close by, but in vain may endeavour by watching, and with still less chance by beating the bushes, to see the bird; yet at other times the guid-guid fearlessly comes near. Its manner of feeding and its general habits are very similar to those of the cheucau.

On the coast,* a small, dusky-coloured bird (Opetiorhynchus Patagonicus) is very common. It is remarkable from its quiet habits : it lives entirely on the sea-beach, like a sandpiper. Besides these birds only few others inhabit this broken land. In my rough notes I describe the strange noises, which. although frequently heard within these gloomy forests, yet scarcely disturb the general silence. The yelping of the guid-guid and the sudden whewwhew of the cheucau sometimes come from afar off, and sometimes from close at hand; the little black wren of Tierra del Fuego occasionally adds its cry ; the creeper (Oxyurus) follows the intruder screaming and twittering; the humming-bird may be seen every now and then darting from side to side, and emitting, like an insect, its shrill chirp; lastly, from the top of some lofty tree, the indistinct but plaintive note of the white-tufted tyrant fly-

* I may mention, as a proof of how great a difference there is between the seasons of the wooded and the open parts of this coast, that on September 20 th, in lat. $34^{\circ}$, these birds had young ones in the nest, while among the Chonos Islands, three months later in the summer, they were only laying; the difference in latitude between these two places being about 700 miles. 
catcher (Myiobius) may be noticed. From the great preponderance in most countries of certain common genera of birds, such as the finches, one feels at first surprised at meeting with the peculiar forms above enumerated, as the commonest birds in any district. In central Chile, two of them, namely, the Oxyurus and Scytalopus, occur, although most rarely. When finding, as in this case, animals which seem to play so insignificant a part in the great scheme of nature, one is apt to wonder why they were created. But it should always be recollected, that in some other country, perhaps, they are essential members of society, or at some former period may have been so. If America, south of 370 , were sunk beneath the waters of the ocean, these two birds might continue to exist in central Chile for a long period, but it is very improbable that their numbers would increase. We should then see a case which must inevitably have happened with very many animals.

These southern seas are frequented by several species of Petrels: the largest kind, Procellaria gigantea, or nelly (quebrantahuesos, or break-bones of the Spaniards), is a common bird, both in the inland channels and on the open sea. In its habits and manner of flight there is a very close resemblance with the albatross; and as with the albatross, a person may watch it for hours together without seeing on what it feeds. The "breakbones" is, however, a rapacious bird, for it was observed by some of the officers at Port St. Antonio chasing a diver, which tried to escape by diving and flying, but was continually struck down, and at last killed by a blow on its head. At Port St. Julian these great petrels were seen killing and devouring young gulls. A second species (Puffinus cinereus), which is common to Europe, Cape Horn, 
and the coast of Peru, is of a much smaller size than the P. gigantea, but, like it, of a dirty black colour. It generally frequents the inland sounds in very large flocks: I do not think I ever saw so many birds of any other sort together as I once saw of these behind the island of Chiloe. Hundreds of thousands flew in an irregular line for several hours in one direction. When part of the flock settled on the water the surface was blackened, and a noise proceeded from them as of human beings talking in the distance.

There are several other species of petrels, but I will only mention one other kind, the Pelacanoides Berardi, which offers an example of those extraordinary cases, of a bird evidently belonging to one well-marked family, yet, both in its habits and structure, allied to a very distinct tribe. This bird never leaves the quiet inland sounds. When disturbed it dives to a distance, and on coming to the surface, with the same movement takes flight. After flying by the rapid movement of its short wings for a space in a straight line, it drops, as if struck dead, and dives again. The form of its beak and nostrils, length of foot, and even the colouring of its plumage, show that this bird is a petrel : on the other hand, its short wings and consequent little power of flight, its form of body and shape of tail, the absence of a hind toe to its foot, its habit of diving, and its choice of situation, make it at first doubtful whether its relationship is not equally close with the auks. It would undoubtedly be mistaken for an auk when seen from a distance, either on the wing, or when diving and quietly swimming about the retired channels of Tierra del Fuego. 


\section{CHAPTER II.}

San Carlos, Chiloe-Osorno in Eruption, contemporaneously with Aconcagua and Coseguina-Ride to Cucao-Impenetrable Forests - Valdivia - Indians - Earthquake - Concepcion-Great Earthquake-Rocks fissured-Appearance of the former Towns -The Sea black and boiling-Direction of the VibrationsStones twisted round-Great Wave-Permanent Elevation of the Land -Area of Volcanic Phenomena - The Connection between the Elevatory and Eruptive Forces-Causes of Earthquakes-Slow Elevation of Mountain-chains.

CHILOE AND CONCEPCION: GREAT EARTHQUAKE.

ON January the 15th we sailed from Low's Harbour, and three days afterwards anchored a second time in the bay of S. Carlos in Chiloe. On the night of the 19th the volcano of Osorno was in action. At midnight the sentry observed something like a large star, which gradually increased in size till about three o'clock, when it presented a very magnificent spectacle. By the aid of a glass, dark objects, in constant succession, were seen, in the midst of a great glare of red light, to be thrown up and to fall down. The light was sufficient to cast on the water a long, bright reflection. Large masses of molten matter seem very commonly to be cast out of the craters in this part of the Cordillera. I was assured that when the Corcovado is in eruption, great masses are projected upwards and are seen to burst in the air, assuming many fantastical forms, such as trees: their size must be immense, for they can be distinguished from the high land behind $\mathrm{S}$. Carlos, which is no less than ninety-three miles from the Corcovado. In the morning the volcano became tranquil.

I was surprised at hearing afterwards that Aconcagua in Chile 480 miles northwards, was in action 
on this same night; and still more surprised to hear that the great eruption of Coseguina (2700 miles north of Aconcagua), accompanied by an earthquake felt over 1000 miles, also occurred within six hours of this same time. This coincidence is the more remarkable, as Coseguina had been dormant for twenty-six years: and Aconcagua most rarely shows any signs of action. It is difficult even to conjecture whether this coincidence was accidental, or shows some subterranean connection. If Vesuvius, Etna, and Hecla in Iceland (all three relatively nearer each other than the corresponding points in South America) suddenly burst forth in eruption on the same night, the coincidence would be thought remarkable; but it is far more remarkable in this case, where the three vents fall on the same great mountain-chain, and where the vast plains along the entire eastern coast, and the upraised recent shells along more than 2000 miles on the western coast, shown in how equable and connected a manner the elevatory forces have acted.

Captain Fitz Roy being anxious that some bearings should be taken on the outer coast of Chiloe, it was planned that Mr. King and myself should ride to Castro, and thence across the island to the Capella de Cucao, situated on the west coast. Having hired horses and a guide, we set out on the morning of the 22d. We had not proceeded far before we were joined by a woman and two boys, who were bent on the same journey. Every one on this road acts on a "hail fellow well met fashion;" and one may here enjoy the privilege, so rare in South America, of travelling without firearms. At first, the country consisted of a succession of hills and valleys: nearer to Castro it became very level. The road itself is a curious affair: 
it consists in its whole length, with the exception of very few parts, of great logs of wood, which are either broad and laid longitudinally, or narrow and placed transversely. In summer the road is not very bad; but in winter, when the wood is rendered slippery from rain, travelling is exceedingly difficult. At that time of the year the ground on each side becomes a morass, and is often overflowed: hence it is necessary that the longitudinal logs should be fastened down by transverse poles, which are pegged on each side into the earth. These pegs render a fall from a horse dangerous, as the chance of alighting on one of them is not small. It is remarkable, however, how active custom has made the Chilotan horses. In crossing bad parts, where the logs had been displaced, they skipped from one to the other almost with the quickness and certainty of a dog. On both hands the road is bordered by the lofty forest-trees, with their bases matted together by canes. When occasionally a long reach of this avenue could be beheld, it presented a curious scene of uniformity : the white line of logs, narrowing in perspective, became hidden by the gloomy forest, or terminated in a zigzag which ascended some steep hill.

Although the distance from S. Carlos to Castro is only twelve leagues in a straight line, the formation of the road must have been a great labour. I was told that several people had formerly lost their lives in attempting to cross the forest. The first who succeeded was an Indian, who cut his way through the canes in eight days, and reached S. Carlos: he was rewarded by the Spanish government with a grant of land. During the summer, many of the Indians wander about the forests (but chiefly in the higher parts, where the woods are not quite so thick), in search of the half-wild cattle, II 
which live on the leaves of the cane and certain trees. It was one of these huntsmen who, by chance, discovered, a few years since, an English vessel, which had been wrecked on the outer coast. The crew were beginning to fail in provisions, and it is not probable that, without the aid of this man, they would ever have extricated themselves from these scarcely penetrable woods. As it was, one seaman died on the march from fatigue. The Indians, in these excursions, steer by the sun; so that, if there is a continuance of cloudy weather, they cannot travel.

The day was beautiful, and the number of trees which were in full flower perfumed the air; yet even this could hardly dissipate the effect of the gloomy dampness of the forest. Moreover, the many dead trunks, that stand like skeletons, never fail to give to these primeval woods a character of solemnity, absent in those of countries long civilized. Shortly after sunset we bivouacked for the night. Our female companion, who was rather good looking, belonged to one of the most respectable families in Castro: she rode, however, astride, and without shoes or stockings. I was surprised at the total want of pride shown by her and her brother. They brought food with them, but at all our meals sat watching Mr. King and myself whilst eating, till we were fairly shamed into feeding the whole party. The night was cloudless, and, while lying in our beds, we enjoyed the sight (and it is a high enjoyment) of the multitude of stars which illumined the darkness of the forest.

January 23d. - We rose early in the morning, and reached the pretty, quiet town of Castro by two o'clock. 'The old governor had died since our last visit, and a Chileno was acting in his place. We had a letter of introduction to Don Pedro, 
whom we found exceedingly hospitable and kind, and more disinterested than is usual on this side of the continent. The next day Don Pedro procured us fresh horses, and offered to accompany us himself. We proceeded to the south, generally following the coast, and passing through several hamlets, each with its large, barn-like chapel built of wood. At Vilipilli, Don Pedro asked the commandant to give us a guide to Cucao. The old gentleman offered to come himself; but for a long time nothing would persuade him that two Englishmen really wished to go to such an out-of-the-way place as Cucao. We were thus accompanied by the two greatest aristocrats in the country, as was plainly to be seen in the manner of all the poorer Indians towards them. At Chonchi we struck across the island, following intricate winding paths, sometimes passing through magnificent forests, and sometimes through pretty cleared spots, abounding with corn and potato crops. This undulating woody country, partially cultivated, reminded me of the wilder parts of England, and therefore had to my eye a most fascinating aspect. At Vilinco, which is situated on the borders of the lake of Cucao, only a few fields were cleared; and all the inhabitants appeared to be Indians. This lake is twelve miles long, and runs in an east and west direction. From local circumstances, the sea-breeze blows very regularly during the day, and during the night it falls calm : this has given rise to strange exaggerations, for the phenomenon, as described to us at San Carlos, was quite a prodigy.

The road to Cucao was so very bad that we determined to embark in a periagua. The commandant, in the most authoritative manner, ordered six Indians to get ready to pull us over, without deigning to tell them whether they would be paid. The 
periagua is a strange, rough boat, but the crew were still stranger: I doubt if six uglier little men ever got into a boat together. They pulled, however, very well and cheerfully. The stroke-oarsman gabbled Indian, and uttered strange cries, much after the fashion of a pig-driver driving his pigs. We started with a light breeze against us, but yet reached the Capella de Cucao before it was late. The country on each side of the lake was one unbroken forest. In the same periagua with us a cow was embarked. To get so large an animal into a small boat appears at first a difficulty, but the Indians managed it in a minute. They brought the cow alongside the boat, which was heeled towards her; then placing two oars under her belly, with their ends resting on the gunwale, by the aid of these levers they fairly tumbled the poor beast, heels over head, into the bottom of the boat, and then lashed her down with ropes. At Cucao we found an unimhabited hovel (which is the residence of the padre when he pays this $\mathrm{Ca}$ pella a visit), where, lighting a fire, we cooked our supper, and were very comfortable.

The district of Cucao is the only inhabited part on the whole west coast of Chiloe. It contains about thirty or forty Indian families, who are scattered along four or five miles of the shore. They are very much secluded fiom the rest of Chiloe, and have scarcely any sort of commerce, except sometimes in a little oil, which they get from sealblubber. They are tolerably dressed in clothes of their own manufacture, and they have plenty to eat. They seemed, however, discontented, yet humble to a degree which it was quite painful to witness. These feelings are, I think, chiefly to be attributed to the harsh and authoritative manner in which they are treated by their rulers. Our com- 
panions, although so very civil to us, behaved to the poor Indians as if they had been slaves rather than free men. They ordered provisions and the use of their horses without ever condescending to say how much, or indeed whether the owners should be paid at all. In the morning, being left alone with these poor people, we soon ingratiated ourselves by presents of cigars and maté. A lump of white sugar was divided between all present, and tasted with the greatest curiosity. The Indians ended all their complaints by saying, "And it is only because we are poor Indians, and know nothing ; but it was not so when we had a king."

The next day, after breakfast, we rode a few miles northward to Punta Huantamó. The road lay along a very broad beach, on which, even after so many fine days, a terrible surf was breaking. I was assured that, after a heavy gale, the roar can be heard at night even at Castro, a distance of no less than twenty-one sea-miles, across a hilly and wooded country. We had some difficulty in reaching the point, owing to the intolerably bad paths; for everywhere in the shade the ground soon becomes a perfect quagmire. The point itself is a bold rocky hill. It is covered by a plant allied, I believe, to Bromelia, and called by the inhabitants Chepones. In scrambling through the beds, our hands were very much scratched. I was amused by observing the precaution our Indian guide took, in turning up his trousers, thinking that they were more delicate than his own hard skin. This plant bears a fruit, in shape like an artichoke, in which a number of seed-vessels are packed: these contain a pleasant, sweet pulp, here much esteemed. I saw, at Low's Harbour, the Chilotans making chichi, or cider, with this fruit: so true is it, as Humboldt remarks, that almost everywhere man II.-D 
finds means of preparing some kind of beverage from the vegetable kingdom. The savages, however, of Tierra del Fuego, and I believe of Australia, have not advanced thus far in the arts.

The coast to the north of Punta Huantamó is exceedingly rugged and broken, and is fronted by many breakers, on which the sea is eternally roaring. Mr. King and myself were anxious to return, if it had been possible, on foot along this coast; but even the Indians said it was quite impracticable. We were told that men have crossed by striking directly through the woods from Cucao to S. Carlos, but never by the coast. On these expeditions, the Indians carry with them only roasted corn, and of this they eat sparingly twice a day.

$26 t h$. - Re-embarking in the periagua, we returned across the lake, and then mounted our horses. The whole of Chiloe took advantage of this week of unusually fine weather to clear the ground by burning. In every direction volumes of smoke were curling upwards. Although the inbabitants were so assiduous in setting fire to every part of the wood, yet I did not see a single fire which they had succeeded in making extensive. We dined with our friend the commandant, and did not reach Castro till after dark. The next morning we started very early. After having ridden for some time, we obtained from the brow of a steep hill an extensive view (and it is a rare thing on this road) of the great forest. Over the horizon of trees, the volcano of Corcovado, and the great flat-topped one to the north, stood out in proud pre-eminence: scarcely another peak in the long range showed its snowy summit. I hope it will be long before I forget this farewell view of the magnificent Cordillera fronting Chiloe. At night we bivouacked under a clondless sky, and the next morning reach- 
ed S. Carlos. We arrived on the right day, for before evening heavy rain commenced.

February 4th.-Sailed from Chiloe. During the last week I made several short excursions. One was to examine a great bed of now-existing shells. elevated 350 feet above the level of the sea: from among these shells large forest-trees were growing. Another ride was to $P$. Huechucucuy. I had with me a guide who knew the country far too well; for he would pertinaciously tell me endless Indian names for every little point, rivulet, and creek. In the same manner as in Tierra del Fuego, the Indian language appears singularly well adapted for attaching names to the most trivial features of the land. I believe every one was glad to say farewell to Chiloe; yet if we could forget the gloom and ceaseless rain of winter, Chiloe might pass for a charming island. There is also something very attractive in the simplicity and humble politeness of the poor inhabitants.

We steered northward along shore, but, owing to thick weather, did not reach Valdivia till the night of the Sth. The next morning the boat proceeded to the town, which is distant about ten miles. We followed the course of the river, occasionally passing a ferw hovels, and patches of ground cleared ont of the otherwise unbroken forest ; and sometimes meeting a canoe with an Indian family. The town is situated on the low banks of the stream, and is so completely buried in a wood of apple-trees that the streets are merely paths in an orchard. I have never seen any country where apple-trees appeared to thrive so well as in this damp part of South America : on the borders of the roads there were many young trees evidently selfsown. In Chiloe the inhabitants possess a marvellously short method of making an orchard. At the 
lower part of almost every branch, small, conical, brown, wrinkled points project: these are always ready to change into roots, as may sometimes be seen, where any mud has been accidentally splashed against the tree. A branch as thick as a man's thigh is chosen in the early spring, and is cut off just beneath a group of these points ; all the smaller branches are lopped off, and it is then placed about two feet deep in the ground. During the ensuing summer the stump throws out long shoots, and sometimes even bears fruit: I was shown one which had produced as many as twenty-three apples, but this was thought very unusual. In the third season the stump is changed (as I have myself seen) into a well-wooded tree, loaded with fruit. An old man near Valdivia illustrated his motto, "Necesidad es la madre del invencion," by giving an account of the several useful things he manufactured from his apples. After making cider, and likewise wine, he extracted from the refuse a white and finely-flavoured spirit; by another process he procured a sweet treacle, or, as he called it, honey. His children and pigs seemed almost to live, during this season of the year, in his orchard.

February 11th.-I set out with a guide on a short ride, in which, however, I managed to see singularly little, either of the geology of the country or of its inhabitants. There is not much cleared land near $V$ aldivia : after crossing a river at the distance of a few miles, we entered the forest, and then passed only one miserable hovel before reaching our sleeping-place for the night. The short difference in latitude, of 150 miles, has given a new aspect to the forest, compared with that of Chiloe. This is owing to a slightly different proportion in the kinds of trees. The evergreens do not appear 
to be quite so numerous ; and the forest, in consequence, has a brighter tint. As in Chiloe, the lower parts are matted together by canes: here, also, another kind (resembling the bamboo of Brazil, and about twenty feet in height) grows in clusters, and ornaments the banks of some of the streams in a very pretty manner. It is with this plant that the Indians make their chuzos, or long tapering spears. Our resting-place was so dirty that I preferred sleeping outside: on these journeys the first night is generally very uncomfortable, because one is not accustomed to the tickling and biting of the fleas. I am sure, in the morning, there was not a space on my legs of the size of a shilling which had not its little red mark where the fiea had feasted.

12th.- We continued to ride through the uncleared forest, only occasionally meeting an Indian on horseback, or a troop of fine mules bringing alerce-planks and corn from the southern plains. In the afternoon one of the horses knocked up : we were then on the brow of a hill which commanded a fine view of the Llanos. The view of these open plains was very refreshing, after being hemmed in and buried in the wilderness of trees. The uniformity of a forest soon becomes very wearisome. This west coast makes me remember with pleasure the free, unbounded plains of Patagonia; yet, with the true spirit of contradiction, I cannot forget how sublime is the silence of the forest. The Llanos are the most fertile and thickly-peopled parts of the country, as they possess the immense advantage of being nearly free from trees. Before learing the forest we crossed some flat little lawns, around which single trees stood, as in an English park: I have often noticed with surprise, in wooded, undulatory districts, that the quite level parts have been destitute of trees. On account of the 
tired horse, I determined to stop at the Mission of Cudico, to the friar of which I had a letter of introduction. Cudico is an intermediate district between the forest and the Llanos. There are a good many cottages, with patches of corn and potatoes, nearly all belonging to Indians. The tribes dependent on Valdivia are "reducidos y Cristianos." The Indians farther northward, about Arauco and Imperial, are still very wild, and not converted; but they have all much intercourse with the Spaniards. The padre said that the Christian Indians did not much like coming to mass, but that otherwise they showed respect for religion. The greatest difficulty is in making them observe the ceremonies of marriage. The wild Indians take as many wives as they can support, and a cacique will sometimes have more than ten : on entering his house, the number may be told by that of the separate fires. Each wife lives a week in turn with the cacique; but all are employed in weaving ponchos, \&c., for his profit. To be the wife of a cacique is an honour much sought after by the Indian women.

The men of all these tribes wear a coarse woollen poncho: those south of Valdivia wear short trousers, and those north of it a petticoat, like the chilipa of the Gauchos. All have their long hair bound by a scarlet fillet, but with no other covering on their heads. These Indians are good-sized men; their cheek-bones are prominent, and in general appearance they resemble the great American family to which they belong; but their physiognomy seemed to me to be slightly different from that of any other tribe which I had before seen. Their expression is generally grave, and even austere, and possesses much character: this may pass either for honest bluntness or fierce determination. The 
long black hair, the grave and much-lined features, and the dark complexion, called to my mind old portraits of James I. On the road we met with none of that humble politeness so universal in Chiloe. Some gave their "mari-mari" (good morning) with promptness, but the greater number did not seem inclined to offer any salute. This independence of manners is probably a consequence of their long wars, and the repeated victories which they alone, of all the tribes in America, have gained over the Spaniards.

I spent the evening very pleasantly, talking with the padre. He was exceedingly kind and hospitable, and, coming from Santiago, had contrived to surround himself with some few comforts. Being a man of some little education, he bitterly complained of the total want of society. With no par ticular zeal for religion, no business or pursuit, how completely must this man's life be wasted! The next day, on our return, we met seven very wildlooking Indians, of whom some were caciques, that had just received from the Chilian government their yearly small stipend for having long remained faithful. They were fine-looking men, and they rode one after the other with most gloomy faces. An old cacique, who headed them, had been, I suppose, more excessively drunk than the rest, for he seemed both extremely grave and very crabbed. Shortly before this two Indians joined 11s, who were travelling from a distant mission to Valdivia concerning some lawsuit. One was a good-humoured old man, but, from his wrinkled, beardless face, looked more like an old woman than a man. I frequently presented both of them with cigars, and, though ready to receive them, and I dare say grateful, they would hardly condescend to thank me. A Chilotan Indian would have taken 
off his hat, and given his "Dios le page!" The travelling was very tedious, both from the badness of the roads, and from the number of great fallen trees, which it was necessary either to leap over, or to avoid by making long circuits. We slept on the road, and next morning reached Valdivia, whence I proceeded on board.

A few days afterwards I crossed the bay with a party of officers, and landed near the fort called Niebla. The buildings were in a most ruinous state, and the gun-carriages quite rotten. Mr. Wickham remarked to the commanding officer that with one discharge they would certainly all fall to pieces. The poor man, trying to put a good face upon it, gravely replied, "No, I am sure, sir, they would stand two!" The Spaniards must have intended to have made this place impregnable. There is now lying in the middle of the courtyard a little mountain of mortar, which rivals in hardness the rock on which it is placed. It was brought from Chile, and cost 7000 dollars. The revolution having broken out, prevented its being applied to any purpose, and now it remains a monument of the fallen greatness of Spain.

I wanted to go to a house about a mile and a half distant, but my guide said it was quite impossible to penetrate the wood in a straight line. He offered, however, to lead me, by following obscure cattle-tracks, the shortest way : the walk, nevertheless, took no less than three hours! This man is employed in hunting strayed cattle; yet, well as he must know the woods, he was, not long since, lost for two whole days, and had nothing to eat. These facts convey a good idea of the impracticability of the forests of these countries. A question often occurred to me, How long does any vestige of a fallen tree remain? This man showed me 
one which a party of fugitive royalists had cut down fourteen years ago; and, taking this as a criterion, I should think a boll a foot and a half in diameter would in thirty years be changed into a heap of monld.

February 20th.-This day has been memorable in the annals of Valdivia for the most severe earthquake experienced by the oldest inhabitant. I happened to be on shore, and was lying down in the wood to rest myself. It came on suddenly, and lasted two minutes, but the time appeared much longer. The rocking of the ground was very sensible. The undulations appeared to my companion and myself to come from due east, whilst others thought they proceeded from southwest: this shows how difficult it sometimes is to perceive the direction of the vibrations. There was no difficulty in standing upright, but the motion made me almost giddy : it was something like the movement of a vessel in a little cross-ripple, or still more like that felt by a person skating over thin ice, which bends under the weight of his body.

A bad earthquake at once destroys our oldest associations : the earth, the very emblem of solidity, has moved beneath our feet like a thin crust over a fluid; one second of time has created in the mind a strange idea of insecurity, which hours of reffection would not have produced. In the forest, as a breeze moved the trees, I felt only the earth tremble, but saw no other effect. Captain Fitz Roy and some officers were at the town during the shock, and there the scene was more striking; for although the houses, from being built of wood, did not fall, they were violently shaken, and the boards creaked and rattled together. The people rushed out of doors in the greatest alarm. It is these accompaniments that create that perfect hor- 
ror of earthquakes, experienced by all who have thus seen as well as felt their effects. Within the forest it was a deeply interesting, but by no meaus an awe-exciting phenomenon. The tides were very curiously affected. The great shock took place at the time of low water; and an old woman who was on the beach told me that the water flowed very quickly, but not in great waves, to highwater mark, and then as quickly returned to its proper level; this was also evident by the line of wet sand. This same kind of quick but quiet movement in the tide happened a few years since at Chiloe, during a slight earthquake, and created much causeless alarm. In the course of the evening there were many weaker shocks, which seemed to produce in the harbour the most complicated currents, and some of great strength.

March 4th.-We entered the harbour of Concepcion. While the ship was beating up to the anchorage I landed on the island of Quiriquina. The mayor-domo of the estate quickly rode down to tell me the terrible news of the great earthquake of the 20th: "That not a house in Concepcion or Talcahuano (the port) was standing; that seventy villages were destroyed; and that a great wave had almost washed away the ruins of Talcahuano."

- Of this latter statement I soon saw abundant proofs, the whole coast being strewed over with timber and furniture as if a thousand ships had been wrecked. Besides chairs, tables, book-shelves, \&c., in great numbers, there were several roofs of cottages, which had been transported almost whole. The storehouses at Talcahuano had been burst open, and great bags of cotton, yerba, and other valuable merchandise were scattered on the shore. During my walk round the island, I ob- 
served that numerous fragments of rock, which, from the marine productions adhering to them, must recently have been lying in deep water, had been cast up high on the beach; one of these was six feet long, three broad, and two thick.

The island itself as plainly showed the overwhelming power of the earthquake as the beach did that of the consequent great wave. The ground, in many parts, was fissured in north and south lines, perhaps caused by the yielding of the parallel and steep sides of this narrow island. Some of the fissures near the cliffs were a yard wide. Many enormous masses had already fallen on the beach, and the inhabitants thought that when the rains commenced far greater slips would happen. The effect of the vibration on the hard, primary slate which composes the foundation of the island was still more curious: the superficial parts of some narrow ridges were as completely shivered as if they had been blasted by gunpowder. This effect, which was rendered conspicuous by the fresh fiactures and displaced soil, must be confined to near the surface, for otherwise there would not exist a block of solid rock throughout Chile; nor is this improbable, as it is known that the surface of a vibrating body is affected differently from the central part. It is, perhaps, owing to this same reason that earthquakes do not cause quite such terrific havoc within deep mines as would be expected. I believe this convulsion has been more effectual in lessening the size of the island of Quiriquina than the ordinary wear-andtear of the sea and weather during the course of a whole century.

The next day I landed at Talcahuano, and afterwards rode to Concepcion. Both towns presented the most awful yet interesting spectacle I ever be- 
held. To a person who had formerly known them, it possibly might have been still more impressive; for the ruins were so mingled together, and the whole scene possessed so little the air of a habitable place, that it was scarcely possible to imagine its former condition. The earthquake commenced at half past eleven o'clock in the forenoon. If it had happened in the middle of the night, the greater number of the inhabitants (which in this one province amount to many thousands) must have perished, instead of less than a hundred : as it was, the invariable practice of running out of doors at the first trembling of the ground alone saved them. In Concepcion, each house, or row of houses, stood by itself, a heap or line of ruins; but in Talcahuano, owing to the great wave, little more than one layer of bricks, tiles, and timber, with here and there part of a wall left standing, could be distinguished. From this circumstance, Concepcion, although not so completely desolated, was a more terrible, and, if I may so call it, picturesque sight. The first shock was very sudden. The mayor-domo at Quiriquina told me, that the first notice he received of it was finding both the horse he rode and himself rolling together on the ground. Rising up, he was again thrown down. He also told me that some cows which were standing on the steep side of the island were rolled into the sea. The great wave caused the destruction of many cattle; on one low island, near the head of the bay, seventy animals were washed off and drowned. It is generally thought that this has been the worst earthquake ever recorded in Chile; knt as the very severe ones occur only after long intervals, this cannot easily be known; nor, indeed, would a much worse slock have made any great difference, for the ruin was now complete. Innu- 
merable small tremblings followed the great earthquake, and within the first twelve days no less than three hundred were counted.

After viewing Concepcion, I cannot understand how the greater number of inhabitants escaped unhurt. The houses in many parts fell outwards, thus forming in the middle of the streets little hillocks of brickwork and rubbish. Mr. Rouse, the English consul, told us that he was at breakfast when the first movement warned him to run out. He had scarcely reached the middle of the courtyard, when one side of his house came thundering down. He retained presence of mind to remember, that if he once got on the top of that part which had already fallen, he would be safe. Not being able, from the motion of the ground, to stand, he crawled up on his hands and knees; and no sooner had he ascended this little eminence, than the other side of the house fell in, the great beams sweeping close in front of his head. With his eyes blinded, and his mouth choked with the cloud of dust which darkened the sky, at last he gained the street. As shock succeeded shock at the interval of a few minutes, no one dared approach the shattered ruins; and no one knew whether his dearest friends and relations were not perishing from the want of help. Those who had saved any property were obliged to keep a constant watch, for thieves prowled about, and at each little trembling of the ground, with one hand they beat their breasts and cried " misericordia!" and then with the other filched what they could from the ruins. The thatched roofs fell over the fires, and flames burst forth in all parts. Hundreds know themselves ruined, and few had the means of providing food for the day.

Earthquakes alome are sufficient to destroy the II. 
prosperity of any country. If beneath England the now inert subterranean forces should exert those powers, which most assuredly in former geological ages they have exerted, how completely would the entire condition of the country be changed! What would become of the lofty houses, thickly packed cities, great manufactories, the beautiful public and private edifices? If the new period of disturbance were first to commence by some great earthquake in the dead of the night, how terrific would be the carnage! England would at once be bankrupt; all papers, records, and accounts would from that moment be lost. Government being unable to collect the taxes, and failing to maintain its authority, the hand of violence and rapine would remain uncontrolled. In every large town famine would go forth, pestilence and death following in its train.

Shortly after the shock, a great wave was seen from the distance of three or four miles, approaching in the middle of the bay with a smooth outline; but along the shore it tore up cottages and trees, as it swept onwards with irresistible force. At the head of the bay it broke in a fearful line of white breakers, which rushed up to a height of 23 vertical feet above the highest spring-tides. Their force must have been prodigious; for at the fort a cannon with its carriage, estimated at four tons in weight, was moved 15 feet inwards. A schooner was left in the midst of the ruins, 200 yards from the beach. The first wave was followed by two others, which in their retreat carried away a vast wreck of floating objects. In one part of the bay a ship was pitched high and dry on shore, was carried off, again driven on shore, and again carried off. In another part, two large vessels anchored near together were whirled about, and their cables were thrice wound round each other: though an- 
chored at a depth of 36 feet, they were for some minutes aground. The great wave must have travelled slowly, for the inhabitants of Talcahuano had time to run up the hills behind the town; and some sailors pulled out seaward, trusting successfully to their boat riding securely over the swell, if they could reach it before it broke. One old woman with a little boy, four or five years old, ran into a boat, but there was nobody to row it out: the boat was consequently dashed against an anchor and cut in twain; the old woman was drowned, but the child was picked up some hours afterwards clinging to the wreck. Pools of salt water were still standing amidst the ruins of the houses, and children, making boats with old tables and chairs, appeared as happy as their parents were miserable. It was, however, exceedingly interesting to observe how much more active and cheerful all appeared than could have been expected. It was remarked with much truth, that from the destruction being universal, no one individual was humbled more than another, or could suspect his friends of coldness-that most grievous result of the loss of wealth. Mr. Rouse, and a large party which he kindly took under his protection, lived for the first week in a garden beneath some appletrees. At first they were as merry as if it had been a picnic; but soon afterwards heavy rain caused much discomfort, for they were absolutely without shelter.

In Captain Fitz Roy's excellent account of the earthquake, it is said that two explosions, one like a column of smoke and another like the blowing of a great whale, were seen in the bay. The water also appeared everywhere to be boiling; and it "became black, and exhaled a most disagreeable sulphureous smell." These latter circumstances 
were observed in the Bay of Valparaiso during the earthquake of 1822 ; they may, I think, be accounted for by the disturbance of the mud at the bottom of the sea containing organic matter in decay. In the Bay of Callao, during a calm day, I noticed, that as the ship dragged her cable over the bottom, its course was marked by a line of bubbles. The lower orders in Talcahuano thought that the earthquake was caused by some old Indian women, who, two years ago, being offended, stopped the volcano of Antuco. This silly belief is curious, because it shows that experience has taught them to observe that there exists a relation between the suppressed action of the volcanoes and the trembling of the ground. It was necessary to apply the witchcraft to the point where their perception of cause and effect failed, and this was the closing of the volcanic vent. This belief is the more singular in this particular instance, because, according to Captain Fitz Roy, there is reason to believe that Antuco was noways affected.

The town of Concepcion was built in the usual Spanish fashion, with all the streets running at right angles to each other; one set ranging S.W. by $\mathrm{W}$., and the other set N.W. by N. The walls in the former direction certainly stood better than those in the latter: the greater number of the masses of brickwork were thrown down towards the N.E. Both these circumstances perfectly agree with the general idea of the undulations having come from the S.W., in which quarter subterranean noises were also heard; for it is evident that the walls running S.W. and N.E., which presented their ends to the point whence the undulations came, would be much less likely to fall than those walls which, running N.W. and S.E., must in their whole lengths have been at the same instant thrown out of the 
perpendicular; for the undulations, coming from the S.W., must have extended in N.W. and S.E. waves, as they passed under the foundations. This may be illustrated by placing books edgeways on a carpet, and then, after the manner suggested by Michell, imitating the undulations of an earthquake: it will be found that they fall with more or less readiness, according as their direction more or less nearly conincides with the line of the waves. The fissures in the ground generally, though not uniformly, extended in a S.E. and N.W. direction, and therefore corresponded to the lines of undulation, or of principal flexure. Bearing in mind all these circumstances, which so clearly point to the S.W. as the chief focus of disturbance, it is a very interesting fact that the island of S. Maria, situated in that quarter, was, during the general uplifting of the land, raised to nearly three times the height of any other part of the coast.

The different resistance offered by the walls, according to their direction, was well exemplified in the case of the Cathedral. The side which fronted the N.E. presented a grand pile of ruins, in the midst of which door-cases and masses of timber stood up, as if floating in a stream. Some of the angular blocks of brickwork were of great dimensions, and they were rolled to a distance on the level plaza, like fragments of rock at the base of some high mountain. The side walls (running S.W. and N.E.), though exceedingly fractured, yet remained standing; but the vast buttresses (at right angles to them, and therefore parallel to the walls that fell) were in many cases cut clean off, as if by a chisel, and hurled to the ground. Some square ornaments, on the coping of these same walls, were moved by the earthquake into a diagonal position. A similar circumstance was observed after an earthE 2 
quake at Valparaiso, Calabria, and other places, including some of the ancient Greek temples.* This twisting displacement at first appears to indicate a vorticose movement beneath each point thus affected; but this is highly improbable. May it not be caused by a tendency in each stone to arrange itself in some particular position, with respect to the lines of vibration, in a manner somewhat similar to pins on a sheet of paper when shaken? Generally speaking, arched doorways or windows stood much better than any other part of the buildings. Nevertheless, a poor lame old man, who had been in the habit, during trifling shocks, of crawling to a certain doorway, was this time crushed to pieces.

I have not attempted to give any detailed description of the appearance of Concepcion, for I feel that it is quite impossible to convey the mingled feelings which I experienced. Several of the officers visited it before me, but their strongest language failed to give a just idea of the scene of desolation. It is a bitter and humiliating thing to see works which have cost man so much time and labour overthrown in one minute; yet compassion for the inhabitants was almost instantly banished by the surprise in seeing a state of things produced in a moment of time which one was accustomed to attribute to a succession of ages. In my opinion, we have scarcely beheld, since leaving England, any sight so deeply interesting.

In almost every severe earthquake, the neighbouring waters of the sea are said to have been greatly agitated. The disturbance seems generally, as in the case of Concepcion, to have been of two

* M. Arago in L'Institut, 1839, p. 337. See also Miers's Chile, vol. i., p. 392 ; also Lyell's Principles of Geology, chap. xv., book ii. 
kinds : first, at the instant of the shock, the water swells high up on the beach with a gentle motion, and then as quietly retreats; secondly, some time afterwards, the whole body of the sea retires from the coast, and then returus in waves of overwhelming force. The first movement seems to be an immediate consequence of the earthquake affecting differently a fluid and a solid, so that their respective levels are slightly deranged: but the second case is a far more important phenomenon. During most earthquakes, and especially during those on the west coast of America, it is certain that the first great movement of the waters has been a retirement. Some authors have attempted to explain this by supposing that the water retains its level, whilst the land oscillates upwards; but surely the water close to the land, even on a rather steep coast, would partake of the motion of the bottom: moreover, as urged by Mr. Lyell, similar movements of the sea have occurred at islands far distant from the chief line of disturbance, as was the case with Juan Fernandez during this earthquake, and with Madeira during the famous Lisbon shock. I suspect (but the subject is a very obscure one) that a wave, however produced, first draws the water from the shore on which it is advancing to break: I have observed that this happens with the little wares from the paddles of a steamboat. It is remarkable, that whilst Talcahuano and Callao (near Lima), both situated at the head of large, shallow bays, have suffered during every severe earthquake from great waves, Valparaiso, seated close to the edge of profoundly deep water, has never been overwhelmed, though so often shaken by the severest shocks. From the great wave not immediately following the earthquake, but sometimes after the interval of even half an hour, and from distant isl- 
ands being affected similarly with the coasts near the focus of the disturbance, it appears that the wave first rises in the offing; and as this is of general occurrence, the cause must be general : I suspect we must look to the line where the less disturbed waters of the deep ocean join the water nearer the coast, which has partaken of the movements of the land, as the place where the great ware is first generated; it would also appear that the wave is larger or smaller according to the extent of shoal water which has been agitated, together with the bottom on which it rested.

The most remarkable effect of this earthquake was the permanent elevation of the land; it would probably be far more correct to speak of it as the cause. There can be no doubt that the land round the Bay of Concepcion was upraised two or three feet; but it deserves notice, that owing to the wave having obliterated the old lines of tidal action on the sloping sandy shores, I could discover no evidence of this fact, except in the united testimony of the inhabitants, that one little rocky shoal, now exposed, was formerly covered with water. At the island of $\mathrm{S}$. Maria (about thirty miles distant) the elevation was greater; on one part, Captain Fitz Roy found beds of putrid muscle-shells still adhering to the rocks, ten feet above high-water mark : the inhabitants had formerly dived at lowwater spring-tides for these shells. The elevation of this province is particularly interesting, from its having been the theatre of several other violent earthquakes, and from the vast numbers of seashells scattered over the land, up to a height of certainly 600, and, I believe, of 1000 feet. At Valparaiso, as I have remarked, similar shells are found at the height of 1300 feet : it is bardly possible to 
doubt that this great elevation has been effected by successive small uprisings, such as that which accompanied or caused the earthquake of this year, and likewise by an insensibly slow rise, which is certainly in progress on some parts of this coast.

The island of Juan Fernandez, 360 miles to the N.E., was, at the time of the great shock of the 20 th, violently shaken, so that the trees beat against each other, and a volcano burst forth under water close to the shore: these facts are remarkable, because this island, during the earthquake of 1751 , was then also affected more violently than other places at an equal distance from Concepcion, and this seems to show some subterranean connection between these two points. Chiloe, about 340 miles southward of Concepcion, appears to have been shaken more strongly than the intermediate district of Valdivia, where the volcano of Villarica was noways affected, whilst in the Cordillera in front of Chiloe, two of the volcanoes burst forth at the same instant in violent action. These two volcanoes, and some neighbouring ones, continued for a long time in eruption, and ten months afterwards were again influenced by an earthquake at Concepcion. Some men, cutting wood near the base of one of these volcanoes, did not perceive the shock of the 20th, although the whole surrounding province was then trembling; here we have an eruption relieving and taking the place of an earthquake, as would have happened at Concepcion, according to the belief of the lower orders, if the volcano of Antuco had not been closed by witchcraft. Two years and three quarters afterwards, Valdivia and Chiloe were again shaken, more violently than on the 20th, and an island in the Chonos Archipelago was permanently elevated more than eight feet. It will give a better idea of the scale 
of these phenomena, if (as in the case of the glaciers) we suppose them to have taken place at corresponding distances in Europe: then would the land from the North Sea to the Mediterranean have been violently shaken, and at the same instant of time a large tract of the eastern coast of England would have been permanently elevated, together with some outlying islands; a train of volcanoes on the coast of Holland would have burst forth in action, and an eruption taken place at the bottom of the sea, near the northern extremity of Ireland; and, lastly, the ancient vents of Auvergne, Cantal, and Mont d'Or would each have sent up to the sky a dark column of smoke, and have long remained in fierce action. Two years and three quarters afterwards, France, from its centre to the English Channel, would have been again desolated by an earthquake, and an island permanently upraised in the Mediterranean.

The space from under which volcanic matter on the 20 th was actually erupted, is 720 miles in one line, and 400 miles in another line at right angles to the first: hence, in all probability, a subterranean lake of lava is here stretched out, of nearly double the area of the Black Sea. From the intimate and complicated manner in which the elevatory and eruptive forces were shown to be connected during this train of phenomena, we may confidently come to the conclusion that the forces which slowly and by little starts uplift continents, and those which at successive periods pour forth volcanic matter from open orifices, are identical. From many reasons, I believe that the frequent quakings of the earth on this line of coast are caused by the rending of the strata necessarily consequent on the tension of the land when upraised and their injection by fluidified rock. This 
rending and injection would, if repeated often enough (and we know that earthquakes repeatedly affect the same areas in the same manner), form a chain of hills; and the linear island of St. Mary, which was upraised thrice the height of the neighbouring country, seems to be undergoing this process. I believe that the solid axis of a mountain differs in its manner of formation from a volcanic hill only in the molten stone having been repeatedly injected instead of having been repeatedly ejected. Moreover, I believe that it is impossible to explain the structure of great mountain-chains, such as that of the Cordillera, where the strata, capping the injected axis of Plutonic rock, have been thrown on their edges along several parallel and neighbouring lines of elevation, except on this view of the rock of the axis having been repeatedly injected, after intervals sufficiently long to allow the upper parts or wedges to cool and become solid; for if the strata had been thrown into their present highly-inclined, vertical, and even inverted positions by a single blow, the very bowels of the earth would have gushed out; and instead of beholding abrupt mountain-axes of rock solidified under great pressure, deluges of lava would have flowed out at innumerable points on every line of elevation.*

* For a full account of the volcanic phenomena which accompanied the earthquake of the 20th, and for the conclusions deducible from them, I must refer to volume v, of the Geological Transactions. 


\section{CHAPTER III.}

Valparaiso-Portillo Pass-Sagacity of Mules-Mountain Torrents-Mines, how discovered-Proofs of the gradual Elevation of the Cordillera-Effect of Snow on Rocks-Geological Structure of the two main Ranges, their distinct Origin and Upheaval-Great Subsidence-Red Snow - Winds - Pinnacles of Snow-Dry and clear Atmosphere-Electricity-Pampas-Zoology of the opposite Sides of the Andes-Locusts-Great Bugs - Mendoza-Uspallata Pass - Silicified Trees buried as they grew-Incas' Bridge - Badness of the Passes exaggeratedCumbre-Casuchas-Valparaiso.

PASSAGE OF THE CORDILLERA.

March $7 t h, 1835 .-\mathrm{WE}$ stayed three days at Concepcion, and then sailed for Valparaiso. The wind being northerly, we only reached the mouth of the harbour of Concepcion before it was dark. Being very near the land, and a fog coming on, the anchor was dropped. Presently a large American whaler appeared close alongside of us, and we heard the Yankee swearing at his men to keep quiet whilst he listened for the breakers. Captain Fitz Roy hailed him, in a loud, clear voice, to anchor where he then was. The poor man must have thought the voice came from the shore: such a Babel of cries issued at once from the ship, every one hallooing out, "Let go the anchor! veer cable! shorten sail!" It was the most laughable thing I ever heard. If the ship's crew had been all cap tains and no men, there could not have been a greater uproar of orders. We afterwards found that the mate stuttered: I suppose all hands were assisting him in giving his orders.

On the 11th we anchored at Valparaiso, and two days afterwards I set out to cross the Cordillera. I proceeded to Santiago, where Mr. Caldcleugh nost kindly assisted me in every possible way in 
making the little preparations which were necessary. In this part of Chile there are two passes across the Andes to Mendoza : the one most commonly used-namely, that of Aconcagua or Uspatlata-is situated some way to the north; the other, called the Portillo, is to the south, and nearer, but more lofty and dangerous.

March 18th.-We set out for the Portillo pass. Leaving Santiago, we crossed the wide burnt-up plain on which that city stands, and in the afternoon arrived at the Maypu, one of the principal rivers in Chile. The valley, at the point where it enters the first Cordillera, is bounded on each side by lofty barren mountains; and although not broad, it is very fertile. Numerons cottages were surrounded by vines, and by orchards of apple, nectarine, and peach trees-their boughs breaking with the weight of the beautiful ripe fruit. In the evening we passed the custom-house, where our luggage was examined. The frontier of Chile is better guarded by the Cordillera than by the waters of the sea. There are very few valleys which lead to the central ranges, and the mountains are quite impassable in other parts by beasts of burden. The custom-house officers were very civil, which was, perhaps, partly owing to the passport which the President of the Republic had given me; but I must express my admiration at the natural politeness of almost every Chileno. In this instance, the contrast with the same class of men in most other countries was strongly marked. I may mention an anecdote, with which I was, at the time, much pleased: We met near Mendoza a little and very fat negress, riding astride on a mule. She had a goître so enormous that it was scarcely possible to avoid gazing at her for a moment; but my two companions almost instantly, by way of apology, II. $-\mathrm{F}$ 
made the common salute of the country by taking off their hats. Where would one of the lower or higher classes in Europe have shown such feeling politeness to a poor and miserable object of a degraded race?

At night we slept at a cottage. Our manner of travelling was delightfully independent. In the inhabited parts we bought a little firewood, hired pasture for the animals, and bivouacked in the corner of the same field with them. Carrying an iron pot, we cooked and ate our supper under a cloudless sky, and knew no trouble. My companions were Mariano Gonzales, who had formerly accompanied me in Chile, and an "arriero," with his ten mules and a "madrina." The madrina (or godmother) is a most important personage: she is an old steady mare, with a little bell round her neck; and wherever she goes, the mules, like good children, follow her. The affection of these animals for their madrinas saves infinite trouble. If several large troops are turned into one field to graze, in the morning the muleteers have only to lead the madrinas a little apart, and tinkle their bells; and although there may be two or three hundred together, each mule immediately knows the bell of its own madrina, and comes to her. It is nearly impossible to lose an old mule; for if detained for several hours by force, she will, by the power of smell, like a dog, track out her companions, or rather the madrina, for, according to the muleteer, she is the chief object of affection. The feeling, however, is not of an individual nature, for I believe I am right in saying that any animal with a bell will serve as a madrina. In a troop, each animal carries, on a level road, a cargo weighing 416 pounds (more than 29 stone), but in a mountainous country 100 pounds less; yet with what delicate 
slim limbs, without any proportional bulk of muscle, these animals support so great a burden! The mule always appears to me a most surprising animal. That a hybrid should possess more reason, memory, obstinacy, social affection, powers of muscular endurance, and length of life, than either of its parents, seems to indicate that art has here outdone nature. Of our ten animals, six were intended for riding, and four for carrying cargoes, each taking turn about. We carried a good deal of food, in case we should be snowed up, as the season was rather late for passing the Portillo.

March 19th.-We rode during this day to the last, and, therefore, most elevated house in the valley. The number of inhabitants became scanty; but wherever water could be brought on the land, it was very fertile. All the main valleys in the Cordillera are characterized by having, on both sides, a fringe or terrace of shingle and sand, rudely stratified, and generally of considerable thickness. These fringes evidently once extended across the valleys, and were united; and the bottoms of the valleys in northern Chile, where there are no streams, are thus smoothly filled up. On these fringes the roads are generally carried, for their surfaces are even, and they rise with a very gentle slope up the valleys: hence, also, they are easily cultivated by irrigation. They may be traced up to a height of between 7000 and 9000 feet, where they become hidden by the irregular piles of debris. At the lower end or mouths of the valleys, they are continuously united to those land-locked plains (also formed of shingle) at the font of the main Cordillera, which I have described in a former chapter as characteristic of the scenery of Chile, and which were undoubtedly deposited when the sea penetrated Chile, as it now does the 
more southern coasts. No one fact in the geology of South America interested me more than these terraces of rudely-stratified shingle. They precisely resemble in composition the matter which the torrents in each valley would deposit if they were checked in their course by any cause, such as enteriug a lake or arm of the sea; but the torrents, instead of depositing matter, are now steadily at work wearing away both the solid rock and these alluvial deposits along the whole line of every main valley and side valley. It is impossible here to give the reasons, but I am convinced that the shingle terraces were accumulated, during the gradual elevation of the Cordillera, by the torrents delivering, at successive levels, their detritus on the beach-heads of long, narrow arms of the sea, first high up the valleys, then lower and lower down, as the land slowly rose. If this be so, and I cannot doubt it, the grand and broken chain of the Cordillera, instead of having been suddenly thrown up, as was till lately the universal, and still is the common opinion of geologists, has been slowly upheaved in mass, in the same gradual manner as the coasts of the Atlantic and Pacific have risen within the recent period. A multitude of facts in the structure of the Cordillera, on this view receive a simple explanation.

The rivers which flow in these valleys ought rather to be called mountain-torrents. 'Their inclination is very great, and their water the colour of mud. The roar which the Maypu made, as it rushed over the great rounded fragments, was like that of the sea. Amidst the din of rushing waters, the noise from the stones, as they rattled one over another, was most distinctly audible even from a distance. This rattling noise, night and day, may be heard along the whole course of the torrent. 
The sound spoke eloquently to the geologist; the thousands and thousands of stones, which, striking against each other, made the one dull, uniform sound, were all hurrying in one direction. It was like thinking on time, where the minute that now glides past is irrecoverable. So was it with these stones; the ocean is their eternity, and each note of that wild music told of one more step towards their destiny.

It is not possible for the mind to comprehend, except by a slow process, any effect which is produced by a cause repeated so often, that the multiplier itself conveys an idea not more definite than the savage implies when he points to the hairs of his head. As often as I have seen beds of mud, sand, and shingle accumulated to the thickness of many thousand feet, I have felt inclined to exclaim that causes, such as the present rivers and the present beaches, could never have ground down and produced such masses. But, on the other hand, when listening to the rattling noise of these torrents, and calling to mind that whole races of animals have passed away from the face of the earth, and that during this whole period, night and day, these stones have gone rattling onwards in their course, I have thought to myself, can any mountains, any continent, withstand such waste?

In this part of the valley the mountains on each side were from 3000 to 6000 or 8000 feet high, with rounded outlines and steep bare flanks. The general colour of the rock was dullish purple, and the stratification very distinct. If the scenery was not beautiful, it was remarkable and grand. We met during the day several herds of cattle, which men were driving down from the higher valleys in the Cordillera. This sign of the approaching winII. 
ter hurried our steps more than was convenient for geologizing. 'The house where we slept was situated at the foot of a mountain, on the summit of which are the mines of S. Pedro de Nolasko. Sir F. Head marvels how mines have been discovered in such extraordinary situations as the bleak summit of the mountain of S. Pedro de Nolasko. In the first place, metallic veins in this country are generally harder than the surrounding strata: hence, during the gradual wear of the hills, they project above the surface of the ground. Secondly, almost every labourer, especially in the northern parts of Chile, understands something about the appearance of ores. In the great mining provinces of Coquimbo and Copiapó, firewood is very scarce, and men search for it over every hill and dale; and by this means nearly all the richest mines have there been discovered. Chanuncillo, from which silver to the value of many hundred thousand pounds has been raised in the course of a few years, was discovered by a man who threw a stone at his loaded donkey, and thinking that it was very heavy, he picked it up, and found it full of pure silver: the vein occurred at no great distance, standing up like a wedge of metal. The miners, also, taking a crowbar with them, often wander on Sundays over the mountains. In this south part of Chile, the men who drive cattle into the Cordillera, and who frequent every ravine where there is a little pasture, are the usual discoverers.

$20 t h$. As we ascended the valley, the vegetation, with the exception of a few pretty alpine flowers, became exceedingly scanty; and of quadrupeds, birds, or insects, scarcely one could be seen. The lofty mountains, their summits marked with a few patches of snow, stood well separated 
from each other, the valleys being filled up with an immense thickness of stratified alluvium. The features in the scenery of the Andes which struck me most, as contrasted with the other mountain chains with which I am acquainted, were, the flat fringes sometimes expanding into narrow plains on each side of the valleys; the bright colours, chiefiy red and purple, of the utterly bare and precipitous hills of porphyry; the grand and continuous wall-like dikes; the plainly-divided strata, which, where nearly vertical, formed the picturesque and wild central pinnacles, but where less inclined, composed the great massive mountains on the outskirts of the range; and, lastly, the smooth conical piles of fine and brightly-coloured detritus, which sloped up at a high angle from the base of the mountains, sometimes to a height of more than 2000 feet.

I frequently observed, both in Tierra del Fuego and within the Andes, that where the rock was covered during the greater part of the year with snow, it was. shivered in a very extraordinary manner into small angular fragments. Scoresby* has observed the same fact in Spitzbergen. The case appears to me rather obscure ; for that part of the mountain which is protected by a mantle of snow must be less subject to repeated and great changes of temperature than any other part. I have sometimes thought that the earth and fragments of stone on the surface were perhaps less effectually removed by slowly percolating snow-watert than

* Scoresby's Arctic Regions, vol. i., p. 122.

+ I have heard it remarked in Shropshire, that the water, when the Severn is flooded from long-continued rain, is much more turbid than when it proceeds from the snow melting on the Welsh mountains. D'Orbigny (tom. i., p. 184), in explaining the cause of the various colours of the rivers in South America, remarks that those with blue or clear water have their source in the Cordillera, where the snow melts. 
by rain, and therefore that the appearance of a quicker disintegration of the solid rock under the snow was deceptive. Whatever the cause may be, the quantity of crumbling stone on the Cordillera is very great. Occasionally in the spring great masses of this detritus slide down the mountains, and cover the snow-drifts in the valleys, thus forming natural ice-houses. We rode over one, the height of which was far below the limit of perpetual snow.

As the evening drew to a close, we reached a singular basin-like plain, called the Valle del Yeso. It was covered by a little dry pasture, and we had the pleasant sight of a herd of cattle amidst the surrounding rocky deserts. The valley takes its name of Yeso from a great bed, I should think at least 2000 feet thick, of white, and, in some parts, quite pure gypsum. We slept with a party of men who were employed in loading mules with this substance, which is used in the manufacture of wine. We set out early in the morning (21st), and continued to follow the course of the river, which had become very small, till we arrived at the foot of the ridge that separates the waters flowing into the Pacific and Atlantic Oceans. The road, which as yet had been good, with a steady but very gradual ascent, now changed into a steep zigzag track up the great range, dividing the republics of Chile and Mendoza.

I will here give a very brief sketch of the geology of the several parallel lines forming the Cordillera. Of these lines there are two considerably higher than the others, namely, on the Chilian side, the Peuquenes ridge, which, where the road crosses it, is 13,210 feet above the sea; and the Portillo ridge, on the Mendoza side, which is 14,305 feet. The lower beds of the Peuquenes ridge, and 
of the several great lines to the westward of it, are composed of a vast pile, many thousand feet in thickness, of porphyries which have flowed as submarine lavas, alternating with angular and rounded fragments of the same rocks, thrown out of the submarine craters. These alternating masses are covered in the central parts by a great thickness of red sandstone, conglomerate, and calcareous clay-slate, associated with, and passing into, prodigious beds of gypsum. In these upper beds shells are tolerably frequent, and they belong to about the period of the lower chalk of Europe. It is an old story, but not the less wonderful, to hear of shells which were once crawling on the bottom of the sea now standing nearly 14,000 feet above its level. The lower beds in this great pile of strata have been dislocated, baked, crystallized, and almost blended together, through the agency of mountain masses of a peculiar white soda-granitic rock.

The other main line, namely, that of the Portillo, is of a totally different formation: it consists chiefly of grand, bare pinnacles of red potash-granite, which low down on the western flank are covered by a sandstone, converted by the former heat into a quartz rock. On the quartz there rest beds of a conglomerate several thousand feet in thickness, which have been upheaved by the red granite, and dip at an angle of $45^{\circ}$ towards the Peuquenes line. I was astonished to find that this conglomerate was partly composed of pebbles, derived from the rocks, with their fossil shells, of the Peuquenes range, and partly of red potash-granite, like that of the Portillo. Hence we must conclude that both the Peuquenes and Portillo ranges were partially upheaved and exposed to wear and tear when the conglomerate was forming; but as the beds of the conglomerate have been thrown 
off at an angle of $45^{\circ}$ by the red Portillo granite (with the underlying sandstone baked by it), we may feel sure that the greater part of the injection and upheaval of the already partially-formed Portillo line took place after the accumulation of the conglomerate, and long after the elevation of the Peuquenes ridge; so that the Portillo, the loftiest line in this part of the Cordillera, is not so old as the less lofty line of the Peuquenes. Evidence derived from an inclined stream of lava at the eastern base of the Portillo might be adduced to show that it owes part of its great height to elevations of a still later date. Looking to its earliest origin, the red granite seems to have been injected on an ancient pre-existing line of white granite and micaslate. In most parts, perhaps in all parts of the Cordillera, it may be concluded that each line has been formed by repeated upheavals and injections, and that the several parallel lines are of different ages. Only thus can we gain time at all sufficient to explain the truly astonishing amount of denudation which these great, though, comparatively with most other ranges, recent mountains have suffered.

Finally, the shells in the Peuquenes or oldest ridge prove, as before remarked, that it has been upraised 14,000 feet since a Secondary period, which in Europe we are accustomed to consider as far from ancient; but since these shells lived in a moderately deep sea, it can be shown that the area now occupied by the Cordillera must have subsided several thousand feet-in northern Chile as much as 6000 feet-so as to have allowed that amount of submarine strata to have been heaped on the bed on which the shells lived. The proof is the same with that by which it was shown, that at a much later period since the tertiary shells of 
Patagonia lived, there must have been there a subsidence of several hundred feet, as well as an ensuing elevation. Daily it is forced home on the mind of the geologist, that nothing, not even the wind that blows, is so unstable as the level of the crust of this earth.

I will make only one other geological remark: although the Portillo chain is here higher than the Peuquenes, the waters, draining the intermediate valleys, have burst through it. The same fact, on a grander scale, has been remarked in the eastern and loftiest line of the Bolivian Cordillera, through which the rivers pass: analogous facts have also been observed in other quarters of the world. On the supposition of the subsequent and gradual elevation of the Portillo line, this can be understood; for a chain of islets would at first appear, and, as these were lifted up, the tides would be always wearing deeper and broader channels between them. At the present day, even in the most retired sounds on the coast of Tierra del Fuego, the currents in the transverse breaks which connect the longitudinal channels are very strong, so that in one transverse channel even a small vessel under sail was whirled round and round.

About noon we began the tedious ascent of the Peuquenes ridge, and then for the first time experienced some little difficulty in our respiration. The mules would halt every fifty yards, and after resting for a few seconds the poor willing animals started of their own accord again. The short breathing from the rarefied atmosphere is called by the Chilenos "puna;" and they have most ridiculous notions concerning its origin. Some say, "all the waters here have puna ;" others, that " where there is snow there is puna;" and this, no doubt, is true. 
The only sensation I experienced was a slight tightness across the head and chest, like that felt on leaving a warm room and running quickly in frosty weather. There was some imagination even in this; for upon finding fossil shells on the highest ridge, I entirely forgot the puna in my delight. Certainly the exertion of walking was extremely great, and the respiration became deep and laborious: I am told that in Potosi (about 13,000 feet above the sea) strangers do not become thoroughly accustomed to the atmosphere for an entire year. The inhabitants all recommend onions for the puna; as this vegetable has sometimes been given in $\mathrm{Eu}-$ rope for pectoral complaints, it may possibly be of real service: for my part, I found nothing so good as the fossil shells!

When about half way up we met a large party with seventy loaded mules. It was interesting to hear the wild cries of the muleteers, and to watch the long descending string of the animals; they appeared so diminutive, there being nothing but the bleak mountains with which they could be compared. When near the summit, the wind, as generally happens, was impetuous and extremely cold. On each side of the ridge we had to pass over broad bands of perpetual snow, which were now soon to be covered by a fresh layer. When we reached the crest and looked backwards, a glorious view was presented. The atmosphere resplendently clear ; the sky an intense blue; the profound valleys; the wild, broken forms; the heaps of ruins, piled up during the lapse of ages; the bright-coloured rocks, contrasted with the quiet mountains of snow-all these together produced a scene no one could have imagined. Neither plant nor bird, excepting a few condors wheeling around the higher pinnacles, distracted my attention from the in. 
animate mass. I felt glad that I was alone: it was like watching a thunder-storm, or hearing in fill orchestra a chorus of the Messiah.

On several patches of the snow I found the Protococcus nivalis, or red snow, so well known from the accounts of Arctic navigators. My attention was called to it by observing the footsteps of the mules stained a pale red, as if their hoofs had been slightly bloody. I at first thought that it was owing to dust blown from the surrounding mountains of red porphyry; for, from the magnifying power of the crystals of snow, the groups of these microscopical plants appeared like coarse particles. The snow was coloured only where it had thawed very rapidly, or had been accidentally crushed. A little rubbed on paper gave it a faint rose tinge mingled with a little brick-red. I afterwards scraped some off the paper, and found that it consisted of groups of little spheres in colourless cases, each the thousandth part of an inch in diameter.

The wind on the crest of the Peuquenes, as just remarked, is generally impetuous and very cold: it is said* to blow steadily from the wêstward or Pacific side. As the observations have been chiefly made in summer, this wind must be an upper and return current. The Peak of Teneriffe, with a less elevation, and situated in lat. $28^{\circ}$, in like manner falls within an upper return stream. At first it appears rather surprising that the tradewind along the northern parts of Chile and on the coast of Peru should blow in so very southerly a direction as it does; but when we reflect that the Cordillera, running in a north and south line, intercepts, like a great wall, the entire depth of the lower atmospheric current, we can easily see that

* Dr. Gillies, in Journ. of Nat. and Geograph. Science, Aug., 1830. This author gives the heights of the Passes.

II.-G 
the trade-wind must be drawn northward, following the line of mountains, towards the equatorial regions, and thus lose part of that easterly movement which it otherwise would have gained from the earth's rotation. At Mendoza, on the eastern foot of the Andes, the climate is said to be subject to long calms, and to frequent though false appearances of gathering rain-storms: we may imagine that the wind, which, coming from the eastward, is thus banked up by the line of mountains, would become stagnant and irregular in its movements.

Having crossed the Peuquenes, we descended into a mountainous country, intermediate between the two main ranges, and then took up our quarters for the night. We were now in the republic of Mendoza. The elevation was probably not under 11,000 feet, and the vegetation, in consequence, exceedingly scanty. The root of a small scrubby plant served as fuel, but it made a miserable fire, and the wind was piercingly cold. Being quite tired with my day's work, I made up my bed as quickly as I could, and went to sleep. About midnight I observed the sky became suddenly clouded: I awakened the arriero to know if there was any danger of bad weather; but he said that without thunder and lightning there was no risk of a heavy snow-storm. The peril is imminent, and the difficulty of subsequent escape great, to any one overtaken by bad weather between the two ranges. A certain cave offers the only place of refuge: Mr. Caldcleugh, who crossed on this same day of the month, was detained there for some time by a heavy fall of snow. Casuchas, or houses of refuge, have not been built in this pass as in that of Uspallata, and therefore, during the autumn, the Portillo is little frequented. I may here remark, that within the main Cordillera rain never falls, for during the 
summer the sky is cloudless, and in winter snowstorms alone occur.

At the place where we slept water necessarily boiled, from the diminished pressure of the atmosphere, at a lower temperature than it does in a less lofty country; the case being the converse of that of a Papin's digester. Hence the potatoes, after remaining for some hours in the boiling water, were nearly as hard as ever. The pot was left on the fire all night, and next morning it was boiled again, but yet the potatoes were not cooked. I found out this by overhearing my two companions discussing the cause: they had come to the simple conclusion "that the cursed pot (which was a new one) did not choose to boil potatoes."

March 22d.-After eating our potato-less breakfast, we travelled across the intermediate tract to the foot of the Portillo range. In the middle of summer cattle are brought up here to graze; but they had now all been removed: even the greater number of the guanacos had decamped, knowing well that if overtaken here by a snow-storm they would be caught in a trap. We had a fine view of a mass of mountains called Tupungato, the whole clothed with unbroken snow, in the midst of which there was a blue patch, no doubt a glacier-a circumstance of rare occurrence in these mountains. Now commenced a heavy and long climb, similar to that up the Peuquenes. Bold, conical hills of red granite rose on each hand; in the valleys there were several broad fields of perpetual snow. These frozen masses, during the process of thawing, had in some parts been converted into pinnacles or columns, " which, as they were high and close together, * This structure in frozen snow was long since observed by Scoresby in the icebergs near Spitzbergen, and lately, with more care, by Colonel Jackson (Journ. of Geograph. Soc., vol. v., p. 12) on the Neva. Mr. Lyell (Principles, vol. iv., p. 360) has com 
made it difficult for the cargo mules to pass. On one of these columns of ice a frozen horse was sticking as on a pedestal, but with its hind legs straight up in the air. The animal, I suppose, must have fallen with its head downward into a hole when the snow was continuous, and afterwards the surrounding parts must have been removed by the thaw.

When nearly on the crest of the Portillo, we were enveloped in a falling cloud of minute frozen spicula. This was very unfortunate, as it continued the whole day, and quite intercepted our view. The pass takes its name of Portillo from a narrow cleft or doorway on the highest ridge, through which the road passes. From this point, on a clear day, those vast plains, which uninterruptedly extend to the Atlantic Ocean, can be seen. We descended to the upper limit of vegetation, and found good quarters for the night under the shelter of some large fragments of rock. We met here some passengers, who made anxious inquiries about the state of the road. Shortly after it was dark the clouds suddenly cleared away, and the effect was quite magical. The great mountains, bright with the full moon, seemed impending over us on all sides, as over a deep crevice : one morning, very early, I witnessed the same striking effect. As soon as the clouds were dispersed it froze severely; but as there was no wind, we slept very comfortably.

The increased brilliancy of the moon and stars at this elevation, owing to the perfect transparency pared the fissures, by which the columnar structures seems to be determined, to the joints that traverse nearly all rocks, but which are best seen in the non-stratified masses. I may observe, that in the case of the frozen snow the columnar structure must be owing to a "metamorphic" action, and not to a process during deposition. 
of the atmosphere, was very remarkable. Travellers having observed the difficulty of judging heights and distances amidst lofty mountains, have generally attributed it to the absence of objects of comparison. It appears to me that it is fully as much owing to the transparency of the air confounding objects at different distances, and likewise partly to the novelty of an unusual degree of fatigue arising from a little exertion, habit being thus opposed to the eridence of the senses. I am sure that this extreme clearness of the air gires a peculiar character to the landscape, all objects appearing to be brought nearly into one plane, as in a drawing or panorama. The transparency is, I presume, owing to the equable and high state of atmospheric dryness. This dryness was shown by the manner in which woodwork shrank (as I soon found by the trouble my geological hammer gave me); by articles of food, such as bread and sugar, becoming extremely hard; and by the preservation of the skin and parts of the flesh of the beasts which had perished on the road. To the same cause we must attribute the singular facility with which electricity is excited. My fiannel waistcoat, when rubbed in the dark, appeared as if it had been washed with phosphorus; every hair on a dog's back crackled; even the linen sheets, and leathern straps of the saddle, when handled, emitted sparks.

March $23 d$.-The descent on the eastern side of the Cordillera is much shorter or steeper than on the Pacific side; in other words, the mountains rise more abruptly from the plains than from the alpine country of Chile. A level and brilliantly white sea of clouds was stretched out beneath our feet, shutting out the view of the equally level Pampas. We soon entered the band of clouds, and did 
not again emerge from it that day. About noon, finding pasture for the animals and bushes for firewood at Los Arenales, we stopped for the night. This was near the uppermost limit of bushes, and the elevation, I suppose, was between seven and eight thousand feet.

I was much struck with the marked difference between the vegetation of these eastern valleys and those on the Chilian side; yet the climate, as well as the kind of soil, is nearly the same, and the difference of longitude very trifling. The same remark holds good with the quadrupeds, and, in a lesser degree, with the birds and insects. I may instance the mice, of which I obtained thirteen species on the shores of the Atlantic, and five on the Pacific, and not one of them is identical. We must except all those species which habitually or occasionally frequent elevated mountains, and certain bircls which range as far south as the Strait of Magellan. This fact is in perfect accordance with the geological history of the Andes; for these mountains have existed as a great barrier since the present races of animals have appeared, and therefore, unless we suppose the same species to have been created in two different places, we ought not to expect any closer similarity between the organic beings on the opposite sides of the Andes than on the opposite shores of the ocean. In both cases, we must leave out of the question those kinds which have been able to cross the barrier, whether of solid rock or salt water.*

A great number of the plants and animals were

* This is merely an illustration of the admirable laws, first laid down by My. Lyell, on the geographical distribution of animals, as influenced by geological changes. The whole reasoning, of course, is founded on the assumption of the immutability of species; otherwise the difference in the species in the two regions might be considered as superinduced during a length of time. 
absolutely the same as, or most closely allied to, those of Patagonia. We here have the agouti, bizcacha, three species of armadillo, the ostrich, certain kinds of partridges, and other birds, none of which are ever seen in Chile, but are the characteristic animals of the desert plains of Patagonia. We have likewise many of the same (to the eyes of a person who is not a botanist) thorny, stunted bushes, withered grass, and dwarf plants. Even the black, slowly-crawling beetles are closely similar, and some, I believe, on rigorous examination, absolutely identical. It had always been to me a subject of regret that we were unavoidably compelled to give up the ascent of the Santa Cruz river before reaching the mountains: I always had a latent hope of meeting with some great change in the features of the country, but I now feel sure that it would only have been following the plains of Patagonia up a mountainous ascent.

March 24th.-Early in the morning I climbed up a mountain on one side of the valley, and enjoyed a far extended view over the Pampas. This was a spectacle to which I had always looked forward with interest, but I was disappointed : at the first glance it much resembled a distant view of the ocean, but in the northern parts many irregularities were soon distinguishable. The most striking feature consisted in the rivers, which, facing the rising sun, glittered like silver threads till lost in the immensity of the distance. At midday we descended the valley and reached a hovel, where an officer and three soldiers were posted to examine passports. One of these men was a thorough-bred Pampas Indian: he was kept much for the same purpose as a bloodhound, to track out any person who might pass by secretly, either on foot or horseback. Some years ago a passenger endeavoured 
to escape detection by making a long circuit over a neighbouring mountain; but this Indian, having by chance crossed his track, followed it for the whole day, over dry and very stony hills, till at last he came on his prey hidden in a gully. We here heard that the silvery clouds which we had admired from the bright region above had poured down torrents of rain. The valley from this point gradually opened, and the hills became mere waterworn hillocks compared to the giants behind: it then expanded into a gently-sloping plain of shingle, covered with low trees and bushes. This talus, although appearing narrow, must be nearly ten miles wide before it blends into the apparently dead-level Pampas. We passed the only house in this neighbourhood, the Estancia of Chaquaio, and at sunset pulled up in the first snug corner, and there bivouacked.

March 25th.-I was reminded of the Pampas of Buenos Ayres by seeing the disk of the rising sun intersected by a horizon level as that of the ocean. During the night a heavy dew fell, a circumstance which we did not experience within the Cordillera. The road proceeded for some distance due east across a low swamp; then meeting the dry plain, it turned to the north towards Mendoza. The distance is two very long days' journey. Our first day's journey was called fourteen leagues to Estacado, and the second seventeen to Luxan, near Mendoza. The whole distance is over a level desert plain, with not more than two or three houses. The sun was exceedingly powerful, and the ride devoid of all interest. There is very little water in this "traversia," and in our second day's journey we found only one little pool. Little water flows from the mountains, and it soon becomes absorbed by the dry and porous soil; so that, although we travelled at 
the distance of only ten or fifteen miles from the outer range of the Cordillera, we did not cross a single stream. In many parts the ground was incrusted with a saline efflorescence; hence we had the same salt-loving plants which are common near Bahia Blanca. The landscape has a uniform character from the Strait of Magellan along the whole eastern coast of Patagonia to the Rio Colorado; and it appears that the same kind of country extends inland from this river in a sweeping line as far as San Luis, and perhaps even further north. To the eastward of this curved line lies the basin of the comparatively damp and green plains of Buenos Ayres. The sterile plains of Mendoza and Patagonia consist of a bed of shingle, worn smooth and accumulated by the waves of the sea, while the Pampas, covered by thistles, clover, and grass, have been formed hy the ancient estuary mud of the Plata.

After our two day's tedious journey, it was refreshing to see in the distance rows of poplars and willows growing round the village and river of Luxan. Shortly before arriving at this place we observed to the south a ragged cloud of a dark, reddishbrown colour. At first we thought that it was smoke from some great fire on the plains; but we soon found that it was a swarm of locusts. They were flying northward; and, with the aid of a light breeze, they overtook us at the rate of ten or fifteen miles an hour. The main body filled the air from a height of twenty feet, to that, as it appeared, of two or three thousand above the ground; " and the sound of their wings was as the sound of chariots of many horses running to battle :" or rather, I should say, like a strong breeze passing through the rigging of a ship. The sky, seen through the advanced guard, appeared like a mezzotinto engraving, but II. 
the main body was impervious to sight; they were not, however, so thick together but that they could escape a stick waved backwards and forwards. When they alighted, they were more numerous than the leaves in the field, and the surface became reddish instead of being green : the swarm having once alighted, the individuals flew from side to side in all directions. Locusts are not an uncommon pest in this country : already, during this season, several smaller swarms had come up from the south, where, as apparently in all other parts of the world, they are bred in the deserts. The poor cottagers in vain attempted, by lighting fires, by shouts, and by waving branches, to avert the attack. This species of locust closely resembles, and perhaps is identical with, the famous Gryllus migratorius of the East.

We crossed the Luxan, which is a river of considerable size, though its course towards the seacoast is very imperfectly known: it is even doubtful whether, in passing over the plains, it is not evaporated and lost. We slept in the village of Luxan, which is a small place surrounded by gardens, and forms the most southern cultivated district in the Province of Mendoza : it is five leagues south of the capital. At night I experienced an attack (for it deserves no less a name) of the Benchuca, a species of Reduvius, the great black bug of the Pampas. It is most disgusting to feel soft, wingless insects, about an inch long, crawling over one's body. Before sucking, they are quite thin, but afterwards they become round and bloated with blood, and in this state are easily crushed. One which I caught at Iquique (for they are found in Chile and Peru) was very empty. When placed on a table, and though surrounded by people, if a finger was presented, the bold insect would imme- 
diately protrude its sucker, make a charge, and, if allowed, draw blood. No pain was caused by the wound. It was curious to watch its body during the act of sucking, as in less than ten minutes it changed from being as flat as a wafer to a globular form. This one feast, for which the benchuca was indebted to one of the officers, kept it fat during four whole months ; but, after the first fortnight, it was quite ready to have another suck.

March 27th.- WVe rode on to Mendoza. The country was beautifully cultivated, and resembled Chile. This neighbourhood is celebrated for its fruit; and certainly, nothing could appear more flourishing than the vineyards and the orchards of figs, peaches, and olives. WVe bought water-melons nearly twice as large as a man's head, most deliciously cool and well-flaroured, for a halfpenny apiece; and for the value of three pence half a wheelbarrowful of peaches. The cultivated and enclosed part of this province is very small; there is little more than that which we passed through between Luxan and the capital. The land, as in Chile, owes its fertility entirely to artificial irrigation; and it is really wonderful to observe how ex traordinarily productive a barren traversia is thus rendered.

We stayed the ensuing day in Mendoza. The prosperity of the place has much declined of late years. The inhabitants say, "it is good to live in, but very bad to grow rich in." The lower orders have the lounging, reckless manners of the Gauchos of the Pampas; and their dress, riding-gear, and habits of life are nearly the same. To my mind, the town had a stupid, forlorn aspect. Neither the boasted alameda, nor the scenery, is at all comparable with that of Santiago ; but to those who, coming from Buenos Ayres, have just crossed the unvaried 
Pampas, the gardens and orchards must appear delightful. Sir F. Head, speaking of the inhabitants, says, "They eat their dimmers, and it is so very hot, they go to sleep-and could they do better?" I quite agree with Sir F. Head: the happy doom of the Mendozinos is to eat, sleep, and be idle.

March 29th.-We set out on our return to Chile by the Uspallata pass, situated north of Mendoza. We had to cross a long and most sterile traversia of fifteen leagues. The soil in parts was absolutely bare, in others covered by numberless dwarf cacti, armed with formidable spines, and called by the inhabitants "little lions." There were also a few low bushes. Although the plain is nearly three thousand feet above the sea, the sun was very powerful; and the heat, as well as the clouds of impalpable dust, rendered the travelling extremely irksome. Our course during the day lay nearly parallel to the Cordillera, but gradually approaching them. Before sunset we entered one of the wide valleys, or rather bays, which open on the plain: this soon narrowed into a ravine, where, a little higher up, the house of Villa Vicencio is situated. As we had ridden all day without a drop of water, both our mules and selves were very thirsty, and we looked out anxiously for the stream which flows down this valley. It was curious to observe how gradually the water made its appearance: on the plain the course was quite dry; by degrees it became a little damper; then puddles of water appeared; these soon became connected; and at Villa Vicencio there was a nice little rivulet.

30th.-The solitary hovel which bears the imposing name of Villa Vicencio has been mentioned by every traveller who has crossed the Andes. I stayed here and at some neighbouring mines during 
the two succeeding days. The geology of the surrounding country is very curious. The Uspallata range is separated from the main Cordillera by a long, narrow plain or basin, like those so often mentioned in Chile, but higher, being six thousand feet above the sea. This range has nearly the same geographical position with respect to the Cordillera which the gigantic Portillo line has, but it is of a totally different origin : it consists of various kinds of submarine lava, alternating with volcanic sandstones and other remarkable sedimentary deposits, the whole having a very close resemblance to some of the tertiary beds on the shores of the Pacific. From this resemblance, I expected to find silicified wood, which is generally characteristic of those formations. I was gratified in a very extraordinary manner. In the central part of the range, at an elevation of about seven thousand feet, I observed on a bare slope some snow-white projecting columns. These were petrified trees, eleven being silicified, and from thirty to forty converted into coarsely-crystallized white calcareous spar. They were abruptly broken off, the upright stumps projecting a few feet above the ground. The trunks measured from three to five feet each in circumference. They stood a little way apart from each other, but the whole formed one group. Mr. Robert Brown has been kind enough to examine the wood: he says it belongs to the fir tribe, partaking of the character of the Araucarian family, but with some curious points of affinity with the yew. The volcanic sandstone in which the trees were embedded, and from the lower part of which they must have sprung, had accumulated in successive thin layers around their trunks; and the stone yet retained the impression of the bark.

It required little geological practice to interpret II.-H 
the marvellous story which this scene at once unfolded ; though, I confess, I was at first so much astonished that I could scarcely believe the plainest. evidence. I saw the spot where a cluster of fine trees once waved their branches on the shores of the Atlantic, when that ocean (now driven back 700 miles) came to the foot of the Audes. I saw that they had sprung from a rolcanic soil which had been raised above the level of the sea, and that subsequently this dry land, with its upright trees, had been let down into the depths of the ocean. In these depths the formerly dry land was covered by sedimentary beds, and these again by enormous streams of submarine lava-one such mass attaining the thickness of a thousand feet; and these deluges of molten stone and aqueous deposits five times altemately had been spread out. The ocean which received such thick masses must have been profoundly deep; but again the subterranean forces exerted themselves, and I now beheld the bed of that ocean forming a chain of mountains more than seven thousand feet in height. Nor had those antagonist forces been dormant which are always at work wearing down the surface of the land: the great piles of strata had been intersected by many wide valleys, and the trees, now changed into silex, were exposed projecting from the volcanic soil, now changed into rock, whence formerly, in a green and budding state, they had raised their lofty heads. Now all is utterly irreclaimable and desert; even the lichen cannot adhere to the stony casts of former trees. Vast and scarcely comprehensible as such changes must ever appear, yet they have all occurred within a period recent when compared with the history of the Cordillera; and the Cordillera itself is absolutely modern as compared with many of the fossiliferous strata of Europe and America. 
April 1st.-We crossed the Uspallata range, and at night slept at the custom-house, the only inhabited spot on the plain. Shortly before leaving the mountains, there was a very extraordinary view : red, purple, green, and quite white sedimentary rocks, alternating with black lavas, were broken up and thrown into all kinds of disorder by masses of porphyry of every shade of colour, from dark brown to the brightest lilac. It was the first view I ever saw which really resembled those pretty sections which geologists make of the inside of the earth.

The next day we crossed the plain, and followed the course of the same great mountain stream which flows by Luxan. Here it was a furious torrent, quite impassable, and appeared larger than in the low country, as was the case with the rivulet of Villa Vicencio. On the evening of the succeeding day we reached the Rio de las Vacas, which is considered the worst stream in the Cordillera to cross. As all these rivers have a rapid and short course, and are formed by the melting of the snow, the hour of the day makes a considerable difference in their volume. In the evening the stream is muddy and full, but about daybreak it becomes clearer and much less impetuous. This we found to be the case with the Rio Vacas, and in the morning we crossed it with little difficulty.

The scenery thus far was very uninteresting compared with that of the Portillo pass. Little can be seen beyond the bare walls of the one grand, flat-bottomed valley, which the road follows up to the highest crest. The valley and the huge rocky mountains are extremely barren: during the two previous nights the poor mules had absolutely no. thing to eat; for, excepting a few low, resinous bushes, scarcely a plant can be seen. In the course of this day we crossed some of the worst passes in 
the Cordillera, but their danger has been much exaggerated. I was told that if I attempted to pass on foot my head would turn giddy, and that there was no room to dismount; but I did not see a place where any one might not have walked over backwards, or got off his mule on either side. One of the bad passes, called las Animas (the Souls), I had crossed, and did not find out till a day afterwards that it was one of the awful dangers. No doubt there are many parts in which, if the mule should stumble, the rider would be hurled down a great precipice; but of this there is little chance. 1 dare say, in the spring, the "laderas," or roads, which each year are formed anew across the piles of fallen detritus, are very bad; but from what I saw, I suspect the real danger is nothing. With cargo-mules the case is rather different, for the loads project so far that the animals, occasionally running against each other, or against a point of rock, lose their balance, and are thrown down the precipices. In crossing the rivers I can well believe that the difficulty may be very great: at this season there was little trouble, but in the summer they must be very hazardous. I can quite imagine, as Sir F. Head describes, the different expressions of those who have passed the gulf, and those who are passing. I never heard of any man being drowned, but with loaded mules it frequently happens. The arriero tells you to show your mule the best line, and then allow her to cross as she likes: the cargomule takes a bad line, and is often lost.

April 4th.-From the Rio de las Vacas to the Puente del Incas, half a day's journey. As there was pasture for the mules, and geology for me, we bivonacked here for the night. When one hears of a natural bridge, one pictures to one's self some deep and narrow ravine, across which a bold mass 
of rock has fallen, or a great arch hollowed out like the vault of a cavern. Instead of this, the Incas' Bridge consists of a crust of stratified shingle, cemented together by the deposits of the neighbouring hot springs. It appears as if the stream had scooped out a channel on one side, leaving an overhanging ledge, which was met by earth and stones falling down from the opposite cliff. Certainly an oblique junction, as would happen in such a case, was very distinct on one side. The Bridge of the Incas is by no means worthy of the great monarchs whose name it bears.

5th.-We had a long day's ride across the central ridge, from the Incas' Bridge to the Ojos del Agua, which are situated near the lowest casucha on the Chilian side. These casuchas are round little towers, with steps outside to reach the floor, which is raised some feet above the ground on account of the snow-drifts. They are eight in number, and, under the Spanish government, were kept during the winter well stored with food and charcoal, and each courier had a master-key. Now they only answer the purpose of caves, or, rather, dungeons. Seated on some little eminence, they are not, however, ill suited to the surrounding scene of desolation. The zigzag ascent of the Cumbre, or the partition of the waters, was very steep and tedious; its height, according to Mr. Pentland, is 12,454 feet. The road did not pass over any perpetual snow, although there were patches of it on both hands. The wind on the summit was exceedingly cold, but it was impossible not to stop for a few minutes to admire, again and again, the colour of the heavens and the brilliant transparency of the atmosphere. The scenery was grand: to the westward there was a fine chaos of mountains, divided by profound ravines. Some snow generally falls $\mathrm{H} 2$ 
hefore this period of the season, and it has even happened that the Cordillera have been finally closed by this time. But we were most fortunate. The sky, by night and by day, was cloudless, excepting a few round little masses of vapour that floated over the highest pinnacles. I have often seen these islets in the sky, marking the position of the Cordillera, when the far-distant mountains have been hidden beneath the horizon.

April 6th.-In the morning we found some thief had stolen one of our mules and the bell of the madrina. We therefore rode only two or three miles down the valley, and stayed there the ensuing day in hopes of recovering the mule, which the arriero thought had been hidden in some ravine. The scenery in this part had assumed a Chilian character: the lower sides of the mountains, dotted over with the pale, ever-green Quillay-tree, and with the great chandelier-like cactus, are certainly more to be admired than the bare eastern valleys; but I cannot quite agree with the admiration expressed by some travellers. The extreme pleasure, I suspect, is chiefly owing to the prospect of a good fire and of a good supper, after escaping from the cold regions above; and I am sure I most heartily participated in these feelings.

Sth.-We left the valley of the Aconcagua, by which we had descended, and reached in the evening a cottage near the Villa de St. Rosa. The fertility of the plain was delightful: the autumn being advanced, the leaves of many of the fruittrees were falling; and of the labourers, some were busy in drying figs and peaches on the roofs of their cottages, while others were gathering the grapes from the vineyards. It was a pretty scene; but I missed that pensive stillness which makes the autumn in England indeed the evening of the year. 
On the 10th we reached Santiago, where I received a very kind and hospitable reception from $\mathrm{Mr}$. Caldcleugh. My excursion only cost me twentyfour days, and never did I more deeply enjoy an equal space of time. A few days afterwards I returned to Mr. Corfield's house at Valparaiso.

\section{CHAPTER IV.}

Coast-road to Coquimbo-Great Loads carried by the MinersCoquimbo-Earthquake-Step-formed Terraces-Absence of recent Deposits-Contemporaneousness of the Tertiary Formations-Excursion up the Valley-Road to Guasco-DesertsValley of Copiapó-Rain and Earthquakes - HydrophobiaThe Despoblado-Indian Ruins-Probable Change of Climate -River-bed arched by an Earthquake-Cold Gales of WindNoises from a Hill-Iquique-Salt Alluvium-Nitrate of Soda - Lima-Unhealthy Country-Ruins of Callao, overthrown by an Earthquake-Recent Subsidence-Elevated Shells on San Lorenzo, their Decomposition-Plain with embedded Shells and Fragments of Pottery-Antiquity of the Indian Race.

NORTHERN CHILE AND PERU.

April 27th.-I SET out on a journey to Coquimbo, and thence through Guasco to Copiapó, where Captain Fitz Roy kindly offered to pick me up in the Beagle. The distance in a straight line along the shore northward is only 420 miles; but my mode of travelling made it a very long journey. I bought four horses and two mules, the latter carrying the luggage on alternate days. The six animals together only cost the value of twenty-five pounds sterling, and at Copiapó I sold them again for twenty-three. We travelled in the same independent manner as before, cooking our own meals, and sleeping in the open air. As we rode towards the Viño del Mar, I took a farewell view of Valparaiso, and admired its picturesque appearance. For geological purposes I made a detour from the 
high road to the foot of the Bell of Quillota. We passed through an alluvial district rich in gold, to the neighbourhood of Limache, where we slept. Washing for gold supports the inhabitants of numerous hovels, scattered along the side of each little rivulet; but, like all those whose gains are uncertain, they are unthrifty in their habits, and consequently poor.

$28 t h$.- In the afternoon we arrived at a cottage at the foot of the Bell Nountain. The inhabitants were freeholders, which is not very usual in Chile. They supported themselves on the produce of a garden and a little field, but were very poor. Capital is here so deficient, that the people are obliged to sell their green corn while standing in the field, in order to buy necessaries for the ensuing year. Wheat, in consequence, was dearer in the very district of its production than at Valparaiso, where the contractors live. The next day we joined the main road to Coquimbo. At night there was a very light shower of rain: this was the first drop that had fallen since the heavy rain of September 11th and 12th, which detained me a prisoner at the Baths of Cauquenes. The interval was seven and a half months; but the rain this year in Chile was rather later than usual. The distant Andes were now covered by a thick mass of snow, and were a glorious sight.

May 2d. - The road continued to follow the coast, at no great distance from the sea. The few trees and bushes which are common in central Chile decreased rapidly in numbers, and were replaced by a tall plant, something like a yucca in appearance. The surface of the country, on a small scale, was singularly broken and irregular, abrupt little peaks of rock rising out of small plains or basins. The indented coast and the bottom of 
the neighbouring sea, studded with breakers, would, if converted into dry land, present similar forms; and such a conversion, without doubt, has taken place in the part over which we rode.

$3 d$.-Quilimari to Conchalee. The country became more and more barren. In the valleys there was scarcely sufficient water for any irrigation; and the intermediate land was quite bare, not supporting even goats. In the spring, after the winter showers, a thin pasture rapidly springs up, and cattle are then driven down from the Cordillera to graze for a short time. It is curious to observe how the seeds of the grass and other plants seem to accommodate themselves, as if by an acquired habit, to the quantity of rain which falls on different parts of this coast. One shower far northward at Copiapó produces as great an effect on the vegetation as two at Guasco, and as three or four in this district. At Valparaiso, a winter so dry as greatly to injure the pasture, would at Guasco produce the most unusual abundance. Proceeding northward, the quantity of rain does not appear to decrease in strict proportion to the latitude. At Conchalee, which is only 67 miles north of Valparaiso, rain is not expected till the end of May, whereas at Valparaiso some generally falls early in April: the annual quantity is likewise small in proportion to the lateness of the season at which it cornmences.

$4 t h$. - Finding the coast-road devoid of interest of any kind, we turned inland towards the mining district and valley of Illapel. This valley, like every other in Chile, is level, broad, and very fertile: it is bordered on each side either by cliffs of stratified shingle or by bare rocky mountains. Above the straight line of the uppermost irrigating ditch all is brown as on a high road, while all below is 
of as bright a green as verdigris, from the beds of alfarfa, a kind of clover. $\mathrm{IV}^{\top} \mathrm{e}$ proceeded to Los Hornos, another mining district, where the principal hill was drilled with holes, like a great ants'nest. The Chilian miners are a peculiar race of men in their habits. Living for weeks together in the most desolate spots, when they descend to the villages on feast-days there is no excess or extravagance into which they do not run. They sometimes gain a considerable sum, and then, like sailors with prize-money, they try how soon they can contrive to squander it. They drink excessively, buy quantities of clothes, and in a few days return penniless to their miserable abodes, there to work harder than beasts of burden. This thoughtlessness, as with sailors, is evidently the result of a similar manner of life. Their daily food is found them, and they acquire no habits of carefulness; moreover, temptation and the means of yielding to it are placed in their power at the same time. On the other hand, in Cornwall, and some other parts of England, where the system of selling part of the vein is followed, the miners, from being obliged to act and think for themselves, are a singularly intelligent and well-conducted set of men.

The dress of the Chilian miner is peculiar and rather picturesque. He wears a very long shirt of some dark-coloured baize, with a leathern apron, the whole being fastened round his waist by a bright-coloured sash. His trousers are very broad, and his small cap of scarlet cloth is made to fit the head closely. The met a party of these miners in full costume, carrying the body of me of their companions to be buried. They marched at a very quick trot, four men supporting the corpse. One set, having run as hard as they could for about two hundred yards, were relieved by four others, who 
had previously dashed on ahead on horseback. Thus they proceeded, encouraging each other by wild cries : altogether, the scene formed a most strange funeral.

We continued travelling northward, in a zigzag line, sometimes stopping a day to geologize. The cuuntry was so thinly inhabited, and the track so obscure, that we often had difficulty in finding our way. On the 12th I stayed at some mines. The ore in this case was not considered particularly good, but, from being abundant, it was supposed the mine would sell for about thirty or forty thousand dollars (that is, 6000 or $\$ 000$ pounds sterling); yet it had been bought by one of the English associations for an ounce of gold ( $£ 3 \mathrm{Ss}$.). The ore is yellow pyrites, which, as I have already remarked, before the arrival of the English was not supposed to contain a particle of copper. On a scale of profits nearly as great as in the above instance, piles of cinders, abounding with minute globules of metallic copper, were purchased; yet with these advantages, the mining associations, as is well known, contrived to lose immense sums of money. The folly of the greater number of the commissioners and shareholders amounted to infatuation: a thousand pounds per annum given in some cases to entertain the Chilian authorities; libraries of well-bound geological books; miners brought out for particular metals, as tin, which are not found in Chile; contracts to supply the miners with milk, in parts where there are no cows; machinery where it could not possibly be used; and a hundred similar arrangements, bore witness to our absurdity, and to this day afford amusement to the natives. Yet there can be no doubt that the same capital, well employed in these mines, would have yielded an immense return: a confidential man of business, 
a practical miner and assayer, would have been all that was required.

Captain Head has described the wonderful load which the "Apires," truly beasts of burden, carry up from the deepest mines. I confess I thought the account exaggerated; so that I was glad to take an opportunity of weighing one of the loads, which I picked out by hazard. - It required considerable exertion on my part, when standing directly over it, to lift it from the ground. The load was considered under weight when found to be 197 pounds. The apire had carried this up eighty perpendicular yards-part of the way by a steep passage, but the greater part up notched poles, placed in a zigzag line up the shaft. According to the general regulation, the apire is not allowed to halt for breath except the mine is six hundred feet deep. The average load is considered as rather more than 200 pounds; and I have been assured that one of 300 pounds (twenty-two stone and a half), by way of a trial, has been brought up from the deepest mine! At this time the apires were bringing up the usual load twelve times in the day, that is, 2400 pounds from eighty yards deep; and they were employed in the intervals in breaking and picking ore.

These men, excepting from accidents, are healthy, and appear cheerful. Their bodies are not very muscular. They rarely eat meat once a week, and never oftener, and then only the hard, dry charqui. Although with a knowledge that the labour was voluntary, it was nevertheless quite revolting to see the state in which they reached the mouth of the mine: their bodies bent forward, leaning with their arms on the steps, their legs bowed, their muscles quivering, the perspiration streaming from their faces over their breasts, their 
nostrils distended, the corners of their mouth forcibly drawn back, and the expulsion of their breath most laborious. Each time they draw their breath they utter an articulate cry of "ay-ay," which ends in a sound rising from deep in the chest, but shrill like the note of a fife. After staggering to the pile of ore, they emptied the " carpacho;" in two or three seconds, recovering their breath, they wiped the sweat from their brows, and, apparently quite fresh, descended the mine again at a quick pace. This appears to me a wonderful instance of the amount of labour which habit, for it can be nothing else, will enable a man to endure.

In the evening, talking with the mayor-domo of these mines about the number of foreigners now scattered over the whole country, he told me that, though quite a young man, he remembers when he was a boy at school at Coquimbo, a holyday being given to see the captain of an English ship, who was brought to the city to speak to the governor. He believes that nothing would have induced any boy in the school, himself included, to have gone close to the Englishman, so deeply had they been impressed with an idea of the heresy, contamination, and evil to be derived from contact with such a person. To this day they relate the atrocious actions of the bucaniers; and especially of one man, who took away the figure of the Virgin Mary, and returned the year after for that of St. Joseph, saying it was a pity the lady should not have a husband. I heard also of an old lady who, at a dinner in Coquimbo, remarked how wonderfully strange it was that she should have lived to dine in the same room with an Englishman; for she remembered as a girl, that twice, at the mere cry of "Los Ingleses," every soul, carrying what valuables they could, had taken to the mountains.

II. 
14th.-We reached Coquimbo, where we stayed a few days. The town is remarkable for nothing but its extreme quietness. It is said to contain from 6000 to 8000 inhabitants. On the morning of the 17th it rained lightly, the first time this year, for about five hours. The farmers, who plant corn near the sea-coast, where the atmosphere is more humid, taking advantage of this shower, would break up the ground; after a second they would put the seed in; and if a third shower should fall, they would reap a good harvest in the spring. It was interesting to watch the effect of this trifling amount of moisture. Twelve hours afterwards the ground appeared as dry as ever; yet, after an interval of ten days, all the hills were faintly tinged with green patches, the grass being sparingly scattered in hair-like fibres a full inch in length. Before this shower every part of the surface was bare as on a high road.

In the evening, Captain Fitz Roy and myself were dining with Mr. Edwards, an English resident, well known for his hospitality by all who have visited Coquimbo, when a sharp earthquake happened. I heard the forecoming rumble; but, from the screams of the ladies, the running of the servants, and the rush of several of the gentlemen to the doorway, I could not distinguish the motion. Some of the women afterwards were crying with terror, and one gentleman said he should not be able to sleep all night, or if be did, it would only be to dream of falling houses. The father of this person had lately lost all his property at Talcahuano, and he himself had only just escaped a falling roof at Valparaiso in 1822. He mentioned a curious coincidence which then happened: he was playing at cards, when a German, one of the party, got up, and said he would never sit in a room in 
these countries with the door shut, as, owing to his having done so, he had nearly lost his life at Copiapó. Accordingly, he opened the door; and no sooner had he done this, than he cried out, "Here it comes again!" and the famous shock commenced. The whole party escaped. The danger in an earthquake is not from the time lost in opening a door, but from the chance of its becoming jammed by the movement of the walls.

It is impossible to be much surprised at the fear which natives and old residents, though some of them known to be men of great command of mind, so generally experience during earthquakes. I think, however, this excess of panic may be partly attributed to a want of habit in governing their fear, as it is not a feeling they are ashamed of. Indeed, the natives do not like to see a person indifferent. I heard of two Englishmen who, sleeping in the open air during a smart shock, knowing that there was no danger, did not rise. The natives cried out indignantly, "Look at those heretics, they will not even get out of their beds!"

I spent some days in examining the step-formed terraces of shingle, first noticed by Captain B. Hall, and believed by Mr. Lyell to have been formed by the sea during the gradual rising of the land. This certainly is the true explanation, for I found numerous shells of existing species on these terraces. Five narrow, gently sloping, fringe-like terraces rise one behind the other, and where best developed are formed of shingle: they front the bay, and sweep up both sides of the valley. At Guasco, north of Coquimbo, the phenomenon is displayed on a much grander scale, so as to strike with surprise even some of the inhabitants. The terraces are there much broader, and may be called 
plains; in some parts there are six of them, but generally only five; they run up the valley for thirty-seven miles from the coast. These step-formed terraces or frínges closely resemble those in the valley of S. Cruz, and, except in being on a smaller scale, those great ones along the whole coastline of Patagonia. They have undoubtedly been formed by the denuding power of the sea during long periods of rest in the gradnal elevation of the continent.

Shells of many existing species not only lie on the surface of the terraces at Coquimbo (to a height of 250 feet), but are embedded in a friable calcareous rock, which in some places is as much as between twenty and thirty feet in thickness, but is of little extent. These modern beds rest on an ancient tertiary formation containing shells, apparently all extinct. Although I examined so many hundred miles of coast on the Pacific, as well as Atlantic side of the continent, I found no regular strata containing sea-shells of recent species, excepting at this place, and at a few points northward on the road to Guasco. This fact appears to me highly remarkable; for the explanation generally given by geologists, of the absence in any district of stratified fossiliferous deposits of a given period, namely, that the surface then existed as dry land, is not here applicable; for we know from the shells strewed on the surface, and embedded in loose sand or mould, that the land for thousands of miles along both coasts has lately been submerged. The explanation, no doubt, must be sought in the fact, that the whole southern part of the continent has been for a long time slowly rising, and therefore, that all matter deposited along shore in shallow water must have been soon brought up, and slowly exposed to the wearing action of the sea-beach; and 
it is only in comparatively shallow water that the greater number of marine organic beings can flourish, and in such water it is obviously impossible that strata of any great thickness can accumulate. To show the vast power of the wearing action of sea-beaches, we need only appeal to the great cliffs along the present coast of Patagonia, and to the escarpments or ancient sea-cliffs at different levels, one above another, on that same line of coast.

The old underlying tertiary formation at Coquimbo appears to be of about the same age with several deposits on the coast of Chile (of which that of Navedad is the principal one), and with the great formation of Patagonia. Both at Navedad and in Patagonia there is evidence that, since the shells (a list of which has been seen by Professor E. Forbes) there intombed were living, there has been a subsidence of several hundred feet, as well as an ensuing elevation. It may naturally be asked how it comes that, although no extensive fossiliferous deposits of the recent period, nor of any period intermediate between it and the ancient tertiary epoch, have been preserved on either side of the continent, yet that at this ancient tertiary epoch sedimentary matter containing fossil remains should have been deposited and preserved at different points in north and south lines, over a space of 1100 miles on the shores of the Pacific, and of at least 1350 miles on the shores of the Atlantic, and in an east and west line of 700 miles across the widest part of the continent. I believe the explanation is not difficult, and that it is, perhaps, applicable to nearly analogous facts observed in other quarters of the world. Considering the enormous power of denudation which the sea possesses, as shown by numberless facts, it is not probable that a sedimentary deposit, when being upraised, could pass 
through the ordeal of the beach, so as to be preserved in sufficient masses to last to a distant period, without it were originally of wide extent, and of considerable thickness : now it is impossible, on a moderately shallow bottom, which alone is favourable to most living creatures, that a thick and widely extended covering of sediment could be spread out, without the bottom sank down to receive the successive layers. This seems to have actually taken place at about the same period in southern Patagonia and Chile, though these places are a thousand miles apart. Hence, if prolonged movements of approximately contemporaneous subsidence are generally widely extensive, as I am strongly inclined to believe from my examination of the Coral Reefs of the great oceans-or if, confining our view to South America, the subsiding movements have been coextensive with those of elevation, by which, within the same period of existing shells, the shores of Peru, Chile, Tierra del Fuego, Patagonia, and La Plata have been upraised-then we can see that at the same time, at far distant points, circumstances would have been favourable to the formation of fossiliferous deposits, of wide extent and of considerable thickness; and such deposits, consequently, would have a good chance of resisting the wear and tear of successive beachlines, and of lasting to a future epoch.

May 21st.-I set out in company with Don Jose Edwards to the silver-mine of Arqueros, and thence up the valley of Coquimbo. Passing through a mountainous country, we reached by nightfall the mines belonging to Mr. Edwards. I enjoyed my night's rest here from a reason which will not be fully appreciated in England, namely, the absence of fleas! The rooms in Coquimbo swarm with 
them; but they will not live here at the height of only three or four thousand feet: it can scarcely be the trifling diminution of temperature, but some other cause, which destroys these troublesome insects at this place. The mines are now in a bad state, though they formerly yielded about 2000 pounds in weight of silver a year. It has been said that "a person with a copper-mine will gain; with silver, he may gain; but with gold, he is sure to lose." This is not true : all the large Chilian fortunes have been made by mines of the more precious metals. A short time since, an English physician returned to England from Copiapó, taking with him the profits of one share in a silver-mine, which amounted to about 24,000 pounds sterling. No doubt a copper-mine, with care, is a sure game, whereas the other is gambling, or, rather, taking a ticket in a lottery. The owners lose great quantities of rich ores, for no precautions can prevent robberies. I heard of a gentleman laying a bet with another that one of his men should rob him before his face. The ore, when brought out of the mine, is broken into pieces, and the useless stone thrown on one side. A couple of the miners who were thus employed pitched, as if by accident, two fragments away at the same moment, and then cried out, for a joke, "Let us see which rolls furthest." The owner, who was standing by, bet a cigar with his friend on the race. The miner, by this means, watched the very point amongst the rubbish where the stone lay. In the evening he picked it up and carried it to his master, showing him a rich mass of silver ore, and saying, "This was the stone on which you won a cigar by its rolling so far."

May 23d.-We descended into the fertile valley of Coquimbo, and followed it till we reached a Hacienda belonging to a relation of Don Jose, 
where we stayed the next day. I then rode one day's journey further, to see what were declared to be some petrified shells and beans, which latter turned out to be small quartz pebbles. We passed through several small villages; and the valley was beautifully cultivated, and the whole scenery very grand. We were here near the main Cordillera, and the surrounding hills were lofty. In all parts of northern Chile, fruit-trees produce much more abundantly at a considerable height near the Andes than in the lower country. The figs and grapes of this district are famous for their excellence, and are cultivated to a great extent. This valley is, perhaps, the most productive one north of Quillota: I believe it contains, including Coquimbo, 25,000 inhabitants. The next day I returned to the Hacienda, and thence, together with Don Jose, to Coquimbo.

June 2d.- We set out for the valley of Guasco, following the coast-road, which was considered rather less desert than the other. Our first day's ride was to a solitary house, called Yerba Buena, where there was pasture for our horses. The shower mentioned as having fallen a fortnight ago only reached about half way to Guasco; we had, therefore, in the first part of our journey a most faint tinge of green, which soon faded quite away. Even where brightest, it was scarcely sufficient to remind one of the fresh turf and budding flowers of the spring of other countries. While travelling through these deserts one feels like a prisoner shut up in a gloomy court, who longs to see something green and to smell a moist atmosphere.

June $3 d$.-Yerba Buena to Carizal. During the first part of the day we crossed a mountainous, rocky desert, and afterwards a long, deep, sandy plain, strewed with broken sea-shells: There was 
very little water, and that little saline: the whole country, from the coast to the Cordillera, is an uninhabited desert. I saw traces only of one living animal in abundance, namely, the shells of a Bulimus, which were collected together in extraordinary numbers on the driest spots. In the spring one humble little plant sends out a few leaves, and on these the snails feed. As they are seen only very early in the morning, when the ground is slightly damp with dew, the Guasos believe that they are bred from it. I have observed in other places that extremely dry and sterile districts, where the soil is calcareous, are extraordinarily favourable to land-shells. At Carizal there were a few cottages, some brackish water, and a trace of cultivation; but it was with difficulty that we purchased a little corn and straw for our horses.

4th.-Carizal to Sauce. We continued to ride over desert plains tenanted by large herds of guanaco. We crossed also the valley of Chañeral; which, although the most fertile one between Guasco and Coquimbo, is very narrow, and produces so little pasture, that we could not purchase any for our horses. At Sauce we found a very civil old gentleman, superintending a copper smeltingfurnace. As an especial favour, he allowed me to purchase at a high price an armful of dirty straw, which was all the poor horses had for supper after their long day's journey. Few smelting-furnaces are now at work in any part of Chile; it is found more profitable, on account of the extreme scarcity of firewood, and from the Chilian method of reduction being so unskilful, to ship the ore for Swansea. The next day we crossed some mountains to Freyrina, in the valley of Guasco. During each day's ride further northward the vegetation became more and more scanty; even the great 
chandelier-like cactus was here replaced by a different and much smaller species. During the winter months, both in northern Chile and in Peru, a uniform bank of clouds hangs, at no great height, over the Pacific. From the mountains we had a very striking view of this white and brilliant aërial field, which sent arms up the valleys, leaving islands and promontories in the same manner as the sea does in the Chonos Archipelago and in Tierra del Fuego.

We stayed two days at Freyrina. In the valley of Guasco there are four small towns. At the mouth there is the port, a spot entirely desert, and without any water in the immediate neighbourhood. Five leagues higher up stands Freyrina, a long, straggling village, with decent, whitewashed houses. Again, ten leagnes further up, Ballenar is situated; and above this, Guasco Alto, a horticultural village, famous for its dried fruit. On a clear day the view up the valley is very fine; the straight opening terminates in the far-distant snowy Cordillera; on each side an infinity of crossing lines are blended together in a beautiful haze. The foreground is singular, from the number of parallel and step-formed terraces; and the included strip of green valley, with its willow bushes, is contrasted on both hands with the naked hills. That the surrounding country was most barren will be readily believed, when it is known that a shower of rain had not fallen during the last thirteen months. The inhabitants heard with the greatest envy of the rain at Coquimbo; from the appearance of the sky they had hopes of equally good fortune, which, a fortnight afterwards, were realized. I was at Copiapó at the time; and there the people, with equal envy, talked of the abundant rain at Guasco. After two or three very dry 
years, perhaps with not more than one shower during the whole time, a rainy year generally follows, and this does more harm than even the drought. The rivers swell, and cover with gravel and sand the narrow strips of ground which alone are fit for cultivation. The floods also injure the irrigating ditches. Great devastation had thus been caused three years ago.

June 8 th.-We rode on to Ballenar, which takes its name from Ballenagh in Ireland, the birthplace of the family of O'Higgins, who, under the Spanish government, were presidents and generals in Chile. As the rocky mountains on each hand were concealed by clouds, the terrace-like plains gave to the valley an appearance like that of Santa Cruz in Patagonia. After spending one day at Ballenar, I set out, on the 10th, for the upper part of the valley of Copiapó. We rode all day over an uninteresting country. I am tired of repeating the epithets barren and sterile. These words, however, as commonly used, are comparative; I have always applied them to the plains of Patagonia, which can boast of spiny bushes and some tufts of grass; and this is absolute fertility as compared with northern Chile. Here, again, there are not many spaces of two hundred yards square where some little bush, cactus, or lichen may not be discovered by careful examination; and in the soil seeds lie dormant, ready to spring up during the first rainy "winter. In Peru, real deserts occur over wide tracts of country. In the evening we arrived at a valley, in which the bed of the streamlet was damp : following it up, we came to tolerably good water. During the night, the stream, from not being evaporated and absorbed so quickly, flows a league lower down than during the day. Sticks were plentiful for firewood, so that it was a 
god place of bivouac for us, but for the poor animals there was not a mouthful to eat.

June $11 t h .-$ We rode without stopping for twelve hours, till we reached an old smelting-furnace, where there was water and firewood; but our horses again had nothing to eat, being shut up in an old courtyard. The line of road was hilly, and the distant views interesting from the varied colours of the bare mountains. It was almost a pity to see the sun shining constantly over so useless a country; such splendid weather ought to have brightened fields and pretty gardens. The next day we reached the valley of Copiapó. I was heartily glad of it, for the whole journey was a continued source of anxiety; it was most disagreeable to hear, whilst eating our own suppers, our horses gnawing the posts to which they were tied, and to have no means of relieving their hunger. To all appearance, however, the animals were quite fresh, and no one could have told that they had eaten nothing for the last fifty-five hours.

I had a letter of introduction to Mr. Bingley, who received me very kindly at the Hacienda of Potrero Seco. This estate is between twenty and thirty miles long, but very narrow, being generally only two fields wide, one on each side the river. In some parts the estate is of no width, that is to say, the land cannot be irrigated, and therefore is valueless, like the surrounding rocky desert. The small quantity of cultivated land in the whole line of valley does not so much depend on inequalities of level, and consequent unfitness for irrigation, as on the small supply of water. The river this year was remarkably full: here, high up the valley, it reached to the horse's belly, and was about fifteen yards wide, and rapid; lower down it becomes smaller and smaller, and is generally quite lost, 
as happened during one period of thirty years, so that not a drop entered the sea. The inhabitants watch a storm over the Cordillera with great interest, as one good fall of snow provides them with water for the ensuing year. This is of infinitely more consequence than rain in the lower country. Rain, as often as it falls, which is about once in every two or three years, is a great advantage, because the cattle and mules can for some time afterwards find a little pasture on the mountains. But without snow on the Andes, desolation extends throughout the valley. It is on record that three times nearly all the inhabitants have been obliged to emigrate to the south. This year there was plenty of water, and every man irrigated his ground as much as he chose; but it has frequently been necessary to post soldiers at the sluices, to see that each estate took only its proper allowance during so many hours in the week. The valley is said to contain 12,000 souls, but its produce is sufficient only for three months in the year, the rest of the supply being drawn from Valparaiso and the south. Before the discovery of the famous silver-mines of Chanuncillo, Copiapó was in a rapid state of decay; but now it is in a very thriving condition, and the town, which was completely overthrown by an earthquake, has been rebuilt.

The valley of Copiapó, forming a mere riband of green in a desert, runs in a very southerly direction, so that it is of considerable length to its source in the Cordillera. The valleys of Guasco and Copiapó may both be considered as long, narrow islands, separated from the rest of Chile by deserts of rock instead of by salt water. Northward of these there is one other very miserable valley, called Paposo, which contains about two hundred souls; and then there extends the real desert of II. $-\mathrm{K}$ 
Atacama, a barrier far worse than the most turbulent ocean. After staying a few days at Potrero Seco, I proceeded up the valley to the house of Don Benito Cruz, to whom I had a letter of introduction. I found him most hospitable; indeed, it is impossible to bear too strong testimony to the kindness with which travellers are received in almost every part of South America. The next day I hired some mules to take me by the ravine of Jolquera into the central Cordillera. On the second night the weather seemed to foretel a storm of snow or rain, and whilst lying in our beds we felt a trifling shock of an earthquake.

The connection between earthquakes and the weather has been often disputed: it appears to me to be a point of great interest, which is little understood. Humboldt has remarked, in one part of the Personal Narrative,* that it would be difficult for any person who had long resided in New Andalusia, or in Lower Peru, to deny that there exists some connection between these phenomena : in another part, however, he seems to think the connection fanciful. At Guayaquil, it is said that a heavy shower in the dry season is invariably followed by an earthquake. In Northern Chile, from the extreme infrequency of rain, or even of weather foreboding rain, the probability of accidental coincidences becomes very small; yet the inhabitants are here most firmly convinced of some connection between the state of the atmosphere and of the trembling of the ground. I was much struck by

* Vol. iv., p. 11, and vol. ii., p. 217. For the remarks on Guayaquil, see Silliman's Journ., vol. xxiv., p. 384. For those on Tacna, by Mr. Hamilton, see Trans. of British Association, 1840. For those on Coseguina, see Mr. Caldcleugh, in Phil. Trans., 1835. In the former edition, I collected several references on the coincidences between sudden falls in the barometer and earthquakes, and between earthquakes and meteors. 
this when mentioning to some people at Copiapó that there had been a sharp shock at Coquimbo: they immediately cried out, "How fortunate! there will be plenty of pasture there this year." To their minds an earthquake foretold rain as surely as rain foretold abundant pasture. Certainly it did so happen, that on the very day of the earthquake, that shower of rain fell which I have described as in ten days' time producing a thin sprinkling of grass. At other times rain has followed earthquakes at a period of the year when it is a far greater prodigy than the earthquake itself: this happened after the shock of November, 1822, and again in 1829, at Valparaiso; also after that of September, 1833, at Tacna. A person must be somewhat habituated to the climate of these countries to perceive the extreme improbability of rain falling at such seasons, except as a consequence of some law quite unconnected with the ordinary course of the weather. In the cases of great volcanic eruptions, as that of Coseguina, where torrents of rain fell at a time of the year most unusual for it, and " almost unprecedented in Central America," it is not difficult to understand that the volumes of vapour and clouds of ashes might have disturbed the atmospheric equilibrium. Humboldt extends this view to the case of earthquakes unaccompanied by eruptions; but I can hardly conceive it possible that the small quantity of aëriform fluids which then escape from the fissured ground can produce such remarkable effects. There appears much probability in the view first proposed by Mr. P. Scrope, that when the barometer is low, and when rain might naturally be expected to fall, the diminished pressure of the atmosphere over a wide extent of country might well determine the precise day on which the earth, already stretched to the utmost by 
the subterranean forces, should yield, crack, and consequently tremble. It is, however, doubtful how far this idea will explain the circumstance of torrents of rain falling in the dry season during several days after an earthquake unaccompanied by an eruption; such cases seem to bespeak some more intimate connection between the atmospheric and subterranean regions.

Finding little of interest in this part of the ravine, we retraced our steps to the house of Don Benito, where I stayed two days collecting fossil shells and wood. Great prostrate silicified trunks of trees, embedded in a conglomerate, were extraordinarily numerous. I measured one which was fifteen feet in circumference: how surprising it is that every atom of the woody matter in this great cylinder should have been removed and replaced by silex so perfectly that each vessel and pore is preserved! These trees flourished at about the period of our lower chalk; they all belonged to the fir tribe. It was amusing to hear the inhabitants discussing the nature of the fossil shells which I collected, almost in the same terms as were used a century ago in Europe, namely, whether or not they had been thus " born by nature." My geological examination of the country generally created a good deal of surprise amongst the Chilenos : it was long before they could be convinced that I was not hunting for mines. This was sometimes troublesome. I found the most ready way of explaining my employment was to ask them how it was that they themselves were not curious concerning earthquakes and volcanoes? why some springs were hot and others cold? why there were mountains in Chile, and not a hill in La Plata? These bare questions at once satisfied and silenced the greater number; some, however (like a few in England, who are a century behind- 
hand), thought that all such inquiries were useless and impious, and that it was quite sufficient that God had thus made the mountains.

An order had recently been issued that all stray dogs should be killed, and we saw many lying dead on the road. A great number had lately gone mad, and several men had been bitten and had died in consequence. On several occasions hydrophobia has prevailed in this valley. It is remarkable thus to find so strange and dreadful a disease appearing time after time in the same isolated spot. It has been remarked that certain villages in England are in like manner much more subject to this visitation than others. Dr. Unanue states that hydrophobia was first known in South America in 1803 : this statement is corroborated by Azara and Ulloa having never heard of it in their time. Dr. Unanùe says that it broke out in Central America, and slowly travelled southward. It reached Arequipa in 1807; and it is said that some men there, who had not been bitten, were affected, as were some negroes, who had eaten a bullock which had died of hydrophobia. At Ica forty-two people thus miserably perished. The disease came on between twelve and ninety days after the bite; and in those cases where it did come on, death ensued invariably within five days. After 1808, a long interval ensued without any cases. On inquiry, I did not hear of hydrophobia in Van Diemen's land, or in Australia; and Burchell says, that during the five years he was at the Cape of Good Hope, he never heard of an instance of it. Webster asserts that at the Azores hydrophobia has never occurred, and the same assertion has been made with respect to Mauritius and St. Helena.* In so strange a dis-

* Observa. sobre el clima de lima, p. 67. Azara's Travels, vol. i., p. 381. Ulloa's Voyage, vol. ii., p. 28. Burchell's Travels, vol,

II. 
ease, some information might possibly be gained by considering the circumstances under which it. originates in distant climates; for it is improbable that a dog already bitten should have been brought to these distant countries.

At night a stranger arrived at the house of Don Benito, and asked permission to sleep there. $\mathrm{He}$ said he had been wandering about the mountains for seventeen days, having lost his way. He started from Guasco, and, being accustomed to travelling in the Cordillera, did not expect any difficulty in following the track to Copiapó ; but he soon became involved in a labyrinth of mountains, whence he could not escape. Some of his mules had fallen over precipices, and he had been in great distress. His chief difficulty arose from not knowing where to find water in the lower country, so that he was obliged to keep bordering the central ranges.

We returned down the valley, and on the $22 \mathrm{~d}$ reached the town of Copiapó. The lower part of the valley is broad, forming a fine plain like that of Quillota. The town covers a considerable space of ground, each house possessing a garden : but it is an uncomfortable place, and the dwellings are poorly furnished. Every one seems bent on the one object of making money, and then migrating as quickly as possible. All the inhabitants are more or less directly concerned with mines; and mines and ores are the sole subjects of conversation. Necessaries of all sorts are extremely dear, as the distance from the town to the port is eighteen leagues, and the land carriage very expensive, A fowl costs five or six shillings; meat is nearly as dear as in England; firewood, or rather sticks, are

ii., p. 524. Webster's Description of the Azores, p. 124. Voyage à l'Isle de France, par un Officier du Roi, tome i., p. 248. Descrintion of St. Helena, p. 123. 
brought on donkeys from a distance of two or three days' journey within the Cordillera ; and pasturage for animals is a shilling a day: all this, for South America, is wonderfully exorbitant.

June 26th.-I hired a guide and eight mules to take me into the Cordillera by a different line from my last excursion. As the country was utterly desert, we took a cargo and a half of barley mixed with chopped straw. About two leagues above the town, a broad valley, called the "Despoblado," or uninhabited, branches off from that one by which we had arrived. Although a valley of the grandest dimensions, and leading to a pass across the Cordillera, yet it is completely dry, excepting, perhaps, for a few days during some very rainy winter. The sides of the crumbling mountains were furrowed by scarcely any ravines, and the bottom of the main valley, filled with shingle, was smooth and nearly level. No considerable torrent could ever have flowed down this bed of shingle; for if it had, a great cliff-bounded channel, as in all the southern valleys, would assuredly have been formed. 1 feel little doubt that this valley, as well as those mentioned by travellers in Peru, were left in the state we now see them by the waves of the sea, as the land slowly rose. I observed in one place, where the Despoblado was joined by a ravine (which in almost any other chain would have been called a grand valley), that its bed, though composed merely of sand and gravel, was higher than that of its tributary. A mere rivulet of water, in the course of an hour, would have cut a channel for itself; but it was evident that ages had passed away, and no such rivulet had drained this great tributary. It was curious to behold the machinery, if such a term may be used, for the drainage, all, with the last 
trifling exception, perfect, yet without any signs of action. Every one must have remarked how mudbanks, left by the retiring tide, imitate in miniature a country with hill and dale; and here we have the original model in rock, formed as the continent rose during the secular retirement of the ocean, instead of during the ebbing and flowing of the tides. If a shower of rain falls on the mudbank, when left dry, it deepens the already-formed shallow lines of excaration; and so is it with the rain of successive centuries on the bank of rock and soil which we call a continent.

We rode on after it was dark till we reached a side ravine with a small well, called "Agua amarga." The water deserved its name, for, besides being saline, it was most offensively putrid and bitter, so that we could not force ourselves to drink either tea or maté. I suppose the distance from the river of Copiapo to this spot was at least twenty-five or thirty English miles; in the whole space there was not a single drop of water, the country deserving the name of desert in the strictest sense. Yet about half way we passed some old Indian ruins near Punta Gorda: I noticed also in front of some of the valleys, which branch off from the Despoblado, two piles of stones placed a little way apart, and directed so as to point up the mouths of these small valleys. My companions knew nothing about them, and only answered my queries by their imperturbable "quien sabe?"

I observed Indian ruins in several parts of the Cordillera: the most perfect which I saw were the Ruinas de Tambillos, in the Uspallata Pass. Small square rooms were there huddled together in separate groups: some of the doorways were yet standing; they were formed by a cross slab of stone only about three feet high. Ulloa has remark- 
ed on the lowness of the doors in the ancient Peruvian dwellings. These houses, when perfect, must have been capable of containing a considerable number of persons. Tradition says that they were used as halting-places for the Incas when they crossed the mountains. Traces of Indian habitations have been discovered in many other parts, where it does not appear probable that they were used as mere resting-places, but yet where the land is as utterly unfit for any kind of cultivation as it is near the 'Tambillos or at the Incas' Bridge, or in the Portillo Pass, at all which places I saw ruins. In the ravine of Jajuel, near Aconcagua, where there is no pass, I heard of remains of houses situated at a great height, where it is extremely cold and sterile. At first I imagined that these buildings had been places of refuge, built by the Indians on the first arrival of the Spaniards; but I have since been inclined to speculate on the probability of a small change of climate.

In this northern part of Chile, within the Cordillera, old Indian houses are said to be especially numerous : by digging amongst the ruins, bits of woollen articles, instruments of precious metals, and heads of Indian corm are not unfrequently discovered : an arrow-head made of agate, and of precisely the same form with those now used in Tierra del Fuego, was given me. I am aware that the Peruvian Indians now frequently inhabit most lofty and bleak situations; but at Copiapó I was assured by men who had spent their lives in travelling through the Andes, that there were very many ( $m u$ chisimas) buildings at heights so great as almost to border on the perpetual snow, and in parts where there exist no passes, and where the land produces absolutely nothing, and, what is still more extraordinary, where there is no water. Nevertheless, it 
is the opinion of the people of the country (althougn they are much puzzled by the circumstance) that, from the appearance of the houses, the Indians must have used them as places of residence. In this valley, at Punta Gorda, the remains consisted of seven or eight square little rooms, which were of a similar form with those at Tambillos, but built chiefly of mud, which the present inhabitants cannot, either here, or, according to Ulloa, in Peru, imitate in durability. They were situated in the most conspicuous and defenceless position, at the bottom of the flat, broad valley. There was no water nearer than three or four leagues, and that only in very small quantity, and bad: the soil was absolutely sterile; I looked in vain even for a lichen adhering to the rocks. At the present day, with the advantage of beasts of burden, a mine, unless it were very rich, could scarcely be worked here with profit. Yet the Indians formerly chose it as a place of residence! If at the present time two or three showers of rain were to fall annually, instead of one, as now is the case, during as many years, a small rill of water would probably be formed in this great valley; and then, by irrigation (which was formerly so well understood by the Indians), the soil would easily be rendered sufficiently productive to support a few families.

I have convincing proofs that this part of the continent of South America has been elevated near the coast at least from 400 to 500 , and in some parts from 1000 to 1300 feet, since the epoch of existing shells; and further inland the rise possibly may have been greater. As the peculiarly arid character of the climate is evidently a consequence of the height of the Cordillera, we may feel almost sure that before the later elevations the atmosphere could not have been so completely drained of its 
moisture as it now is; and as the rise has been gradual, so would have been the change in climate. On this notion of a change of climate since the buildings were inhabited, the ruins must be of extreme antiquity, but I do not think their preservation under the Chilian climate any great difficulty. We must also admit, on this notion (and this, perhaps, is a greater difficulty), that man has inhabited South America for an immensely long period, inasmuch as any change of climate effected by the elevation of the land must have been extremely gradual. At Valparaiso, within the last 220 years, the rise has been somewhat less than 19 feet: at Lima a sea-beach has certainly been upheaved from 80 to 90 feet within the Indio-human period; but such small elevations could have had little power in deflecting the moisture-bringing atmospheric currents. Dr. Lund, however, found human skeletons in the caves of Brazil, the appearance of which induced him to believe that the Indian race has existed during a vast lapse of time in South America.

When at Lima, I conversed on these subjects* with Mr. Gill, a civil engineer, who had seen much of the interior country. He told me that a conjecture of a change of climate had sometimes crossed his mind, but that he thought that the greater portion of land, now incapable of cultivation, but covered with Indian ruins, had been reduced to this state by the water-conduits, which the Indians formerly constructed on so wonderful a scale, having

* Temple, in his travels through Upper Peru, or Bolivia, in going from Potosi to Oruro, says, "I saw many Indian villages or dwellings in ruins, up even to the very tops of the mountains, attesting a former population where now all is desolate." He makes similar remarks in another place; but I cannot tell whether this desolation has been caused by a want of population or by an altered condition of the land. 
been injured by neglect and by subterranean movements. I may here mention that the Peruvians actually carried their irrigating streams in tunnels through hills of solid rock. Mr. Gill told me he had been employed professionally to examine one; he found the passage low, narrow, crooked, and not of uniform breadth, but of very considerable length. Is it not most wonderful that men should have attempted such operations without the use of iron or gunpowder? Mr. Gill also mentioned to me a most interesting, and, as far as I am aware, quite unparalleled case, of a subterranean disturbance having changed the drainage of a country. Travelling from Casma to Huaraz (not very far distant from Lima), he found a plain covered with ruins and marks of ancient cultivation, but now quite barren. Near it was the dry course of a considerable river, whence the water for irrigation had formerly been conducted. There was nothing in the appearance of the water-course to indicate that the river had not flowed there a few years previously; in some parts, beds of sand and gravel were spread out; in others, the solid rock had been worn into a broad channel, which in one spot was about 40 yards in breadth and $S$ feet deep. It is self-evident that a person following up the course of a stream will always ascend at a greater or less inclination: Mr. Gill, therefore, was much astonished, when walking up the bed of this ancient river, to find himself suddenly going down hill. He imagined that the downward slope had a fall of about 40 or 50 feet perpendicular. We here have unequivocal evidence that a ridge had been uplifted right across the old bed of a stream. From the moment the river-course was thus arched, the water must necessarily have been thrown back, and a new channel formed. From that moment, also, the 
neighbouring plain must have lost its fertilizing stream, and become a desert.

June 27th.-We set out early in the morning, and by midday reached the ravine of Paypote, where there is a tiny rill of water, with a little vegetation, and even a few algarroba trees, a kind of mimosa. From having firewood, a smelting-furnace had formerly been built here: we found a solitary man in charge of it, whose sole employment was hunting guanacos. At night it froze sharply; but, having plenty of wood for our fire, we kept ourselves warm.

28th.-We continued gradually ascending, and the valley now changed into a ravine. During the day we saw several guanacos, and the track of the closely-allied species, the Vicuna: this latter ani$\mathrm{mal}$ is pre-eminently alpine in its habits; it seldom descends much below the limit of perpetual snow, and therefore haunts even a more lofty and sterile situation than the guanaco. The only other animal which we saw in any number was a small fox : I suppose this animal preys on the mice and other small rodents, which, as long as there is the least vegetation, subsist in considerable numbers in very desert places. In Patagonia, even on the borders of the salinas, where a drop of fresh water can never be found, excepting dew, these little animals swarm. Next to lizards, mice appear to be able to support existence on the smallest and driest portions of the earth, even on islets in the midst of great oceans.

The scene on all sides showed desolation, brightened and made palpable by a clear, unclouded sky. For a time such scenery is sublime, but this feeling cannot last, and then it becomes uninteresting. We bivouacked at the foot of the "primera linea," II.-L 
or the first line of the partition of the waters. 'The streams, however, on the east side do not flow to the Atlantic, but into an elevated district, in the middle of which there is a large salina, or salt lake; thus forming a little Caspian Sea at the height, perhaps, of ten thousand feet. Where we slept there were some considerable patches of snow, but they do not remain throughout the year. The winds in these lofty regions obey very regular laws: every day a fresh breeze blows up the valley, and at night, an hour or two after sunset, the air from the cold regions above descends as through a funnel. This night it blew a gale of wind, and the temperature must have been considerably below the freezing-point, for water in a vessel soon became a block of ice. No clothes seemed to oppose any obstacle to the air; I suffered very much from the cold, so that I could not sleep, and in the morning rose with my body quite dull and benumbed.

In the Cordillera further southward people lose their lives from snow-storms; here it sometimes happens from another cause. My guide, when a boy of fourteen years old, was passing the Cordillera with a party in the month of May, and while in the central parts, a furious gale of wind arose, so that the men could hardly cling on their mules, and stones were flying along the ground. The day was cloudless, and not a speck of snow fell, but the temperature was low. It is probable that the thermometer would not have stood very many degrees below the freezing-point, but the effect on their bodies, ill protected by clothing, must have been in proportion to the rapidity of the current of cold air. The gale lasted for more than a day; the men began to lose their strength, and the mules would not move onwards. My guide's brother 
tried to return, but he perished, and his body was found two years afterwards, lying by the side of his mule near the road, with the bridle still in his hand. Two other men in the party lost their fingers and toes ; and, out of two hundred mules and thirty cows, only fourteen mules escaped alive. Many years ago the whole of a large party are supposed to have perished from a similar cause, but their bodies, to this day, have never been discovered. The union of a cloudless sky, low temperature, and a furious gale of wind, must be, I should think, in all parts of the world, an unusual occurrence.

June 29th.-We gladly travelled down the valley to our former night's lodging, and thence to near the Agua amarga. On July 1st we reached the valley of Copiapó. The smell of the fresh clover was quite delightful, after the scentless air of the dry, sterile Despoblado. Whilst staying in the town, I heard an account from several of the inhabitants of a hill in the neighbourhood which they called "El Bramador," the roarer or bellower. I did not at the time pay sufficient attention to the account; but, as far as I understood, the hill was covered by sand, and the noise was produced only when people, by ascending it, put the sand in motion. The same circumstances are described in detail on the authority of Seetzen and Ehrenberg,* as the cause of the sounds which have been heard by many travellers on Mount Sinai near the Red Sea. One person with whom I conversed had himself heard the noise; le described it as very surprising; and he distinctly stated that, al-

* Edinburgh Phil. Journ., Jan., 1830, p. 74 ; and April, 1830, p. 258. Also, Daubeny on Volcanoes, p. 438 ; and Bengal Journ., vol. vii., p. 324 . 
though he could not understand how it was caused, yet it was necessary to set the sand rolling down the acclivity. A horse walking over dry and coarse sand causes a peculiar chirping noise from the friction of the particles, a circumstance which I several times noticed on the coast of Brazil.

Three days afterwards I heard of the Beagle's arrival at the Port, distant eighteen leagues from the town. There is very little land cultivated down the valley; its wide expanse supports a wretched wiry grass, which even the donkeys can hardly eat. This poorness of the vegetation is owing to the quantity of saline matter with which the soil is impregnated. The Port consists of an assemblage of miserable little hovels, situated at the foot of a sterile plain. At present, as the river contains water enough to reach the sea, the inhabitants enjoy the advantage of having fresh water within a mile and a half. On the beach there were large piles of merchandise, and the little place had an air of activity. In the evening I gave my adios, with a hearty good-will, to my companion Mariano Gonzales, with whom I had ridden so many leagues in Chile. The next morning the Beagle sailed for Iquique.

July 12th.-We anchored in the port of Iquique, in lat. $20^{\circ} 12^{\prime}$, on the coast of Peru. The town contains about a thousand inhabitants, and stands on a little plain of sand at the foot of a great wall of rock, 2000 feet in height, here forming the coast. The whole is utterly desert. A light shower of rain falls only once in very many years; and the ravines consequently are filled with detritus, and the mountain-sides covered by piles of fine white sand, even to a height of a thousand feet. During this season of the year a heavy bank of clouds, 
stretched over the ocean, seldom rises above the wall of rocks on the coast. The aspect of the place was most gloomy; the little port, with its few vessels, and small group of wretched houses, seemed overwhelmed, and out of all proportion with the rest of the scene.

The inhabitants live like persons on board a ship: every necessary comes from a distance: water is brought in boats from Pisagua, about forty miles northward, and is sold at the rate of nine reals $(4 s .6 d$.) an eighteen-gallon cask: I bought a wine-bottleful for threepence. In like manner, fire-wood, and, of course, every article of food, is imported. Very few animals can be maintained in such a place: on the ensuing morning I hired with difficulty, at the price of four pounds sterling, two mules and a guide to take me to the nitrate of soda works. These are at present the support of Iquique. This salt was first exported in 1830 : in one year an amount in value of one hundred thousand pounds sterling was sent to France and England. It is principally used as a manure and in the manufacture of nitric acid: owing to its deliquescent property, it will not serve for gunpowder. Formerly there were two exceedingly rich silver-mines in this neighbourhood, but their produce is now very small.

Our arrival in the offing caused some little apprehension. Peru was in a state of anarchy; and each party having demanded a contribution, the poor town of Iquique was in tribulation, thinking the evil hour was come. The people had also their domestic troubles; a short time before, three French carpenters had broken open, during the same night, the two churches, and stolen all the plate: one of the robbers, however, subsequently confessed, and the plate was recovered. The con- 
victs were sent to Arequipa, which, though the capital of this province, is two hundred leagues distant; the government there thought it a pity to punish such useful workmen, who could make all sorts of furniture, and accordingly liberated them. Things being in this state, the churches were again broken open, but this time the plate was not recovered. The inhabitants became dreadfully enraged, and, declaring that none but heretics would thus "eat God Almighty," proceeded to torture some Englishmen, with the intention of afterwards shooting them. At last the authorities interfered, and peace was established.

$13 t h$. - In the morning I started for the saltpetreworks, a distance of fourteen leagues. Having ascended the steep coast-mountains by a zigzag sandy track, we soon came in view of the mines of Guantajaya and St. Rosa. These two small villages are placed at the very mouths of the mines; and, being perched up on hills, they had a still more unnatural and desolate appearance than the town of Iquique. We did not reach the saltpetre-works till after sunset, having ridden all day across an undulating country, a complete and utter desert. The road was strewed with the bones and dried skins of the many beasts of burden which had perished on it from fatigue. Excepting the Vultur aura, which preys on the carcasses, I saw neither bird, quadruped, reptile, nor insect. On the coast-mountains, at the height of about 2000 feet, where during this season the clouds generally hang, a very few cacti were growing in the clefts of rock; and the loose sand was strewed over with a lichen, which lies on the surface quite unattached. This plant belongs to the genus Cladonia, and somewhat resembles the reindeer lichen. In some parts it was in sufficient quantity to tinge the sand, as seen from a 
distance, of a pale yellowish colour. Further inland, during the whole ride of fourteen leagues, I saw only one other vegetable production, and that was a most minute yellow lichen, growing on the bones of the dead mules. This was the first true desert which $I$ had seen : the effect on me was not impressive; but I believe this was owing to my having become gradually accustomed to such scenes, as I rode northward from Valparaiso, through $\mathrm{Co}$ quimbo, to Copiapó. The appearance of the country was remarkable, from being covered by a thick crust of common salt, and of a stratified saliferous alluvium, which seems to have been deposited as the land slowly rose above the level of the sea. The salt is white, very hard, and compact : it occurs in water-worn nodules projecting from the agglutinated sand, and is associated with much gypsum. The appearance of this superficial mass very closely resembled that of a country after snow, before the last dirty patches are thawed. The existence of this crust of a soluble substance over the whole face of the country shows how extraordinarily dry the climate must have been for a long period.

At night I slept at the house of the owner of one of the saltpetre-mines. The country is here as unproductive as near the coast ; but water, having rather a bitter and brackish taste, can be procured by digging wells. The well at this house was thirty-six yards deep : as scarcely any rain falls, it is evident the water is not thus derived; indeed, if it were, it could not fail to be as salt as brine, for the whole surrounding country is incrusted with various saline substances. We must therefore conclude that it percolates under ground from the Cordillera, though distant many leagues. In that direction there are a few small villages, where the inhabi- 
tants, having more water, are enabled to irrigate a little land, and raise hay, on which the mules and asses employed in carrying the saltpetre are fed. The nitrate of soda was now selling at the ship's side at fourteen shillings per hundred pounds : the chief expense is its transport to the sea-coast. The mine consists of a hard stratum, between two and three feet thick, of the nitrate, mingled with a little of the sulphate of soda, and a good deal of common salt. It lies close beneath the surface, and follows for a length of one hundred and fifty miles the margin of a grand basin or plain ; this, from its outline, manifestly must once have been a lake, or, more probably, an inland arm of the sea, as may be inferred from the presence of iodic salts in the saline stratum. The surface of the plain is 3300 feet above the Pacific.

19th. - We anchored in the Bay of Callao, the seaport of Lima, the capital of Peru. We stayed here six weeks, but, from the troubled state of public affairs, I saw very little of the country. During our whole visit the climate was far from being so delightful as it is generally represented. A dull, heavy bank of clouds constantly hung over the land, so that during the first sixteen days I had only one view of the Cordillera behind Lima. These mountains, seen in stages, one above the other, through openings in the clouds, had a very grand appearance. It is almost become a proverb, that rain never falls in the lower part of Peru. Yet this can hardly be considered correct; for during almost every day of our visit there was a thick drizzling mist, which was sufficient to make the streets muddy and one's clothes damp: this the people are pleased to call Peruvian dew. That much rain does not fall is very certain, for the houses are 
covered only with flat roofs made of hardened mud; and on the mole shiploads of wheat were piled up, being thus left for weeks together without any shelter.

I cannot say I liked the very little I saw of Peru: in summer, however, it is said that the climate is much pleasanter. In all seasons, both inhabitants and foreigners suffer from severe attacks of ague. This disease is common on the whole coast of Peru, but is unknown in the interior. The attacks of illness which arise from miasma never fail to appear most mysterious. So difficult is it to judge from the aspect of a country whether or not it is healthy, that if a person had been told to choose within the tropics a situation appearing favourable for health, very probably he would have named this coast. The plain round the outskirts of Callao is sparingly covered with a coarse grass, and in some parts there are a few stagnant, though very small, pools of water. The miasma, in all probability, arises from these; for the town of Arica is similarly circumstanced, and its healthiness was much improved by the drainage of some little pools. Miasma is not always produced by a luxuriant vegetation with an ardent climate; for many parts of Brazil, even where there are marshes and a rank vegetation, are much more healthy than this sterile coast of Peru. The densest forests in a temperate climate, as in Chiloe, do not seem in the slightest degree to affect the healthy condition of the atmosphere.

The island of St. Jago, at the Cape de Verds, offers another strongly-marked instance of a country which any one would have expected to find most healthy, being very much the contrary. I have described the bare and open plains as supporting, during a few weeks after the rainy season, II. 
a thin vegetation, which directly withers away and dries up : at this period the air appears to become quite poisonous, both natives and foreigners often being affected with violent fevers. On the other hand, the Galapagos Archipelago, in the Pacific, with a similar soil, and periodically subject to the same process of vegetation, is perfectly healthy. Humboldt has observed, that, "under the torrid zone, the smallest marshes are the most dangerous, being surrounded, as at Vera Cruz and Carthagena, with an arid and sandy soil, which raises the temperature of the ambient air." ${ }^{*}$ On the coast of Peru, however, the temperature is not hot to any excessive degree, and perhaps, in consequence, the intermittent fevers are not of the most malignant order. In all unhealthy countries, the greatest risk is run by sleeping on shore. Is this owing to the state of the body during sleep, or to a greater abundance of miasma at such times? It appears certain that those who stay on board a vessel, though anchored at only a short distance from the coast, generally suffer less than those actually on shore. On the other hand, I have heard of one remarkable case where a fever broke out among the crew of a man-of-war some hundred miles off the coast of Africa, and at the very same time that one of those fearful periods $\nmid$ of death commenced at Sierra Leone.

No state in South America, since the declaration of independence, has suffered more from anarchy than Peru. At the time of our visit, there were four chiefs in arms contending for supremacy in the

* Political Essay on the Kingdom of New Spain, vol. iv., p. 199.

+ A similar interesting case is recorded in the Madras Medical Quart. Journ., 1839, p. 340. Dr. Ferguson, in his admirable Paper (see 9th vol. of Edinburgh Royal Trans.), shows clearly that the poison is generated in the drying process; and hence that dry, hot countries are often the most unhealthy. 
government : if one succeeded in becoming for a time very powerful, the others coalesced against him ; but no sooner were they victorious, than they were again hostile to each other. The other day, at the Anniversary of the Independence, high mass was performed, the President partaking of the sacrament: during the Te Deum laudamus, instead of each regiment displaying the Peruvian flag, a black one with death's head was unfurled. Imagine a government under which such a scene could be ordered, on such an occasion, to be typical of their determination of fighting to death! This state of affairs happened at a time very unfortunately for me, as I was precluded from taking any excursions much beyond the limits of the town. The barren island of S. Lorenzo, which forms the harbour, was nearly the only place where one could walk securely. The upper part, which is upwards of 1000 feet in height, during this season of the year (winter) comes within the lower limit of the clouds; and in consequence, an abundant cryptogamic vegetation, and a few flowers, cover the summit. On the hills near Lima, at a height but little greater, the ground is carpeted with moss, and beds of beautiful yellow lilies called Amancaes. This indicates a very much greater degree of humidity than at a corresponding height at Iquique. Proceeding northward of Lima, the climate becomes damper, till on the banks of the Guyaquil, nearly under the equator, we find the most luxuriant forests. The change, however, from the sterile coast of Peru to that fertile land is described as taking place rather abruptly in the latitude of Cape Blanco, two degrees south of Guyaquil.

Callao is a filthy, ill-built, small seaport. The inhabitants, both here and at Lima, present every imaginable shade of mixture between European, 
Negro, and Indian blood. They appear a depraved, drunken set of people. The atmosphere is loaded with foul smells, and that peculiar one, which may be perceived in almost every town within the tropics, was here very strong. The fortress, which withstood Lord Cochrane's long siege, has an imposing appearance. But the President, during our stay, sold the brass guns, and proceeded to dismantle parts of it. The reason assigned was, that he had not an officer to whom he could trust so important a charge. He himself had good reasons for thinking so, as he had obtained the presidentship by rebelling while in charge of this same fortress. After we left South America, he paid the penalty in the usual manner, by being conquered, taken prisoner, and shot.

Lima stands on a plain in a valley, formed during the gradual retreat of the sea. It is seven miles from Callao, and is elevated 500 feet above it; but from the slope being very gradual, the road appears absolutely level, so that when at Lima it is difficult to believe one has ascended even one hundred feet: Humboldt has remarked on this singularly deceptive case. Steep, barren hills rise like islands from the plain, which is divided by straight mud-walls into large green fields. In these scarcely a tree grows excepting a few willows, and an occasional clump of bananas and of oranges. The city of Lima is now in a wretched state of decay : the streets are nearly unpaved; and heaps of filth are piled up in all directions, where the black gallinazos, tame as poultry, pick up bits of carrion. The houses have generally an upper story, built, on account of the earthquakes, of plastered woodwork; but some of the old ones, which are now used by several families, are immensely large, and would rival in suites of apartments the most mag- 
nificent in any place. Lima, the City of the Kings, must formerly have been a splendid town. The extraordinary number of churches gives it, even at the present day, a peculiar and striking character, especially when viewed from a short distance.

One day I went out with some merchants to hunt in the immediate vicinity of the city. Our sport was very poor; but I had an opportunity of seeing the ruins of one of the ancient Indian villages, with its mound like a natural hill in the centre. The remains of houses, enclosures, irrigating streams, and burial mounds, scattered over this plain, cannot fail to give one a high idea of the condition and number of the ancient population. When their earthenware, woollen clothes, utensils of elegant forms cut out of the hardest rocks, tools of copper, ornaments of precious stones, palaces, and hydraulic works, are considered, it is impossible not to respect the considerable advance made by them in the arts of civilization. The burial mounds, called Huacas, are really stupendous, although in some places they appear to be natural hills incased and modelled.

There is also another and very different class of ruins, which possesses some interest, namely, those of old Callao, overwhelmed by the great earthquake of 1746 , and its accompanying wave. The destruction must have been more complete even than at Talcahuano. Quantities of shingle almost conceal the foundations of the walls, and vast masses of brickwork appear to have been whirled about like pebbles by the retiring waves. It has been stated that the land subsided during this memorable shock: I could not discover any proof of this; yet it seems far from improbable, for the form of the coast must certainly have undergone some change since the foundation of the old town, as II. - M 
no people in their senses would willingly have chosen for their building-place the narrow spit of shingle on which the ruins now stand. Since our voyage, M. Tschudi has come to the conclusion, by the comparison of old and modern maps, that the coast both north and south of Lima has certainly subsided.

On the island of San Lorenzo, there are very satisfactory proofs of elevation within the recent period; this, of course, is not opposed to the belief of a small sinking of the ground having subsequently taken place. The side of this island fronting the Bay of Callao is worn into three obscure terraces, the lower one of which is covered by a bed a mile in length, almost wholly composed of shells of eighteen species, now living in the adjoining sea. The height of this bed is eighty-five feet. Many of the shells are deeply corroded, and have a much older and more decayed appearance than those at the height of 500 or 600 feet on the coast of Chile. These shells are associated with much common salt, a little sulphate of lime (both probably left by the evaporation of the spray, as the land slowly rose), together with sulphate of soda and muriate of lime. They rest on fragments of the underlying sandstone, and are covered by a few inches thick of detritus. The shells, higher up on this terrace, could be traced scaling off in flakes, and falling into an impalpable powder; and on an upper terrace, at the height of 170 feet, and likewise at some considerably higher points, I found a layer of saline powder of exactly similar appearance, and lying in the same relative position. I have no doubt that this upper layer originally existed as a bed of shells, like that on the eighty-five-feet ledge; but it does not now contain even a trace of organic structure. The powder 
has been analyzed for me by Mr. T. Reeks : it corisists of sulphates and muriates both of lime and soda, with very little carbonate of lime. It is known that common salt and carbonate of lime, left in a mass for some time together, partly decompose each other; though this does not happen with small quantities in solution. As the half-decomposed shells in the lower parts are associated with much common salt, together with some of the saline substances composing the upper saline layer, and as these shells are corroded and decayed in a remarkable manner, I strongly suspect that this double decomposition has here taken place. The resultant salts, however, ought to be carbonate of soda and muriate of lime; the latter is present, but not the carbonate of soda. Hence I am led to imagine that by some unexplained means the carbonate of soda becomes changed into the sulphate. It is obvious that the saline layer could not have been preserved in any country in which abundant rain occasionally fell : on the other hand, this very circumstance, which at first sight appears so highly favourable to the long preservation of exposed shells, has probably been the indirect means, through the common salt not having been washed away, of their decomposition and early decay.

I was much interested by finding on the terrace, at the height of eighty-five feet, embedded amidst the shells and much sea-drifted rubbish, some bits of cotton thread, plaited rush, and the head of a stalk of Indian corn. I compared these relics with similar ones taken out of the Huacas, or old Peruvian tombs, and found them identical in appearance. On the mainland in front of San Lorenzo, near Bellavista, there is an extensive and level plain about a hundred feet high, of which the lower part is formed of alternating layers of sand and 
impure clay, together with some gravel, and the surface, to the depth of from three to six feet, of a reddish loam, containing a few scattered sea-shells and numerous small fragments of coarse red earthenware, more abundant at certain spots than at others. At first I was inclined to believe that this superficial bed, from its wide extent and smoothness, must have been deposited beneath the sea; but I afterwards found in one spot that it lay on an artificial floor of round stones. It seems, therefore, most probable, that at a period when the land stood at a lower level, there was a plain very similar to that now surrounding Callao, which, being protected by a shingle beach, is raised but very little above the level of the sea. On this plain, with its underiying red-clay beds, I imagine that the Indians manufactured their earthen vessels, and that during some violent earthquake the sea broke over the beach, and converted the plain into a temporary lake, as happened round Callao in 1713 and 1746. The water would then have deposited mud, containing fragments of pottery from the kilns, more abundant at some spots than at others, and shells from the sea. This bed with fossil earthenware stands at about the same height with the shells on the lower terrace of San Lorenzo, in which the cotton thread and other relics were embedded. Hence we may safely conclude that within the Indo-human period there has been an elevation, as before alluded to, of more than eightyfive feet; for some little elevation must have been Iost by the coast having subsided since the old maps were engraved. At Valparaiso, although in the 220 years before our visit the elevation cannot have exceeded nineteen feet, yet subsequently to 1817 there has been a rise, partly insensible and partly by a start during the shock of 1822 , of ten 
or eleven feet. The antiquity of the Indo-human race here, judging by the eighty-five feet rise of the land since the relics were embedded, is the more remarkable, as on the coast of Patagonia, when the land stood about the same number of feet lower, the Macrauchenia was a living beast; but as the Patagonian coast is some way distant from the Cordillera, the rising there may have been slower than here. At Bahia Blanca, the elevation has been only a few feet since the numerous gigantic quadrupeds were there entombed; and, according to the generally received opinion, when these extinct animals were living, man did not exist. But the rising of that part of the coast of Patagonia is perhaps noways connected with the Cordillera, but rather with a line of old volcanic rocks in Banda Oriental, so that it may have been infinitely slower than on the shores of Peru. All these speculations, however, must be vague; for who will pretend to say that there may not have been several periods of subsidence intercalated between the movements of elevation? for we know that along the whole coast of Patagonia there have certainly been many and long pauses in the upward action of the elevatory forces. 


\section{CHAPTER V.}

The whole Group volcanic-Number of Craters-Leafless Bushes-Colony at Charles Island-James Island-Salt-lake in Crater-Natural History of the Group-Ornithology, curious Finches-Reptiles-Great Tortoises, Habits of-Marine Lizard, feeds on Sea-weed-Terrestrial Lizard, burrowing Habits, Herbivorous-Importance of Reptiles in the Archipelago-Fish, Shells, Insects-Botany-Americau Ty pe of Organization-Differences in the Species or Faces on different Islands-Tameness of the Birds-Fear of Man, an acquired Instinct.

\section{GALAPAGOS ARCHIPELAGO.}

September $15 t h$.- THis archipelago consists of ten principal islands, of which five exceed the others in size. They are situated under the equator,

Culpepper $I$.

Wenman I.

60 Miles.
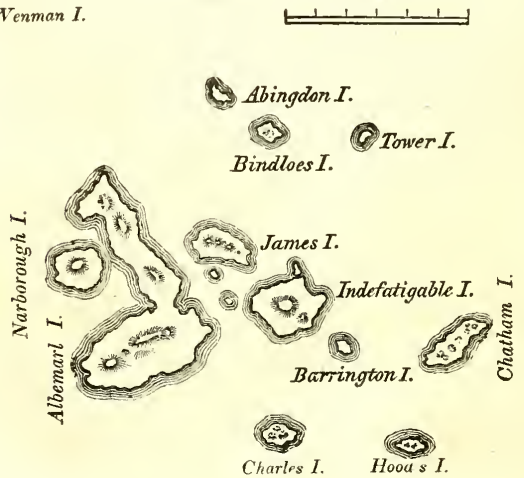
and between five and six hundred miles westward of the coast of America. They are all formed of volcanic rocks; a few fragments of granite, curiously glazed and altered by the heat, can hardly be considered as an exception. Some of the craters surmounting the larger islands are of immense size, and they rise to a height of between three and four thousand feet. Their flanks are studded by innumerable smaller orifices. I scarcely hesitate to affirm that there must be in the whole archipelago at least two thousand craters. These consist either of lava and scoria, or of finely-stratified, sandstone-like tuff. Most of the latter are beautifully symmetrical; they owe their origin to eruptions of volcanic mud without any lava: it is a remarkable circumstance that every one of the twenty-eight tuff-craters which were examined had their southern sides either much lower than the other sides, or quite broken down and removed. As all these craters apparently have been formed when standing in the sea, and as the waves from the trade-wind and the swell from the open Pacific here unite their forces on the southern coasts of all the islands, this singular uniformity in the broken state of the craters, composed of the soft and yielding tuff, is easily explained.

Considering that these islands are placed directly under the equator, the climate is far from being excessively hot. This seems chiefly caused by the singularly low temperature of the surrounding water, brought here by the great southern Polar current. Excepting during one short season very littlo rain falls, and even then it is irregular; but the clouds generally hang low. Hence, whilst the lower parts of the islands are very sterile, the upper parts, at a height of a thousand feet and upwards, possess a damp climate and a tolerably luxuriant 
vegetation. This is especially the case on the windward sides of the islands, which first receive and condense the moisture from the atmosphere.

In the morning (17th) we landed on Chatham Island, which, like the others, rises with a tame and rounded outline, broken here and there by scattered hillocks, the remains of former craters. Nothing could be less inviting than the first appearance. A broken field of black basaltic lava, thrown into the most rugged waves, and crossed by great fissures, is everywhere covered by stunted sun-burned brushwood, which shows little signs of life. The dry and parched surface, being heated by the noonday sun, gave to the air a close and sultry feeling, like that from a stove: we fancied even that the bushes smelt unpleasantly. Although I diligently tried to collect as many plants as possible, I succeeded in getting very few; and such wretched-looking little weeds would have better become an arctic than an equatorial Flora. The brushwood appears, from a short distance, as leafless as our trees during winter; and it was some time before I discovered that not only almost every plant was now in full leaf, but that the greater number were in flower. The commonest bush is one of the Euphorbiaceæ: an acacia, and a great, odd-looking cactus, are the only trees which afford any shade. After the season of heavy rains the islands are said to appear for a short time partially green. The volcanic island of Fernando Noronha, placed in many respects under nearly similar conditions, is the only other country where I have seen a vegetation at all like this of the Galapagos islands.

The Beagle sailed round Chatham Island, and anchored in several bays. One night I slept on shore on a part of the island where black truncated 
cones were extraordinarily numerous: from one small eminence I counted sixty of them, all surmounted by craters more or less perfect. The greater number consisted merely of a ring of red scorize or slags, cemented together, and their height above the plain of lava was not more than from fifty to a hundred feet: none had been very lately active. The entire surface of this part of the island seems to have been permeated, like a sieve, by the subterranean vapours : here and there the lava, whilst soft, has been blown into great bubbles, and in other parts, the tops of caverns similarly formed have fallen in, leaving circular pits with steep sides. From the regular form of the many craters, they gave to the country an artificial appearance, which vividly reminded me of those parts of Staffordshire where the great ironfoundries are most numerous. The day was glowing hot, and the scrambling over the rough surface and through the intricate thickets was very fatiguing, but I was well repaid by the strange Cyclopean scene. As I was walking along I met two large tortoises, each of which must have weighed at least two hundred pounds: one was eating a piece of cactus, and, as I approached, it stared at me and slowly stalked away; the other gave a deep hiss and drew in its head. These huge reptiles, surrounded by the black lava, the leafless shrubs, and large cacti, seemed to my fancy like some antediluvian animals. The few dull-coloured birds cared no more for me than they did for the great tortoises.

23d. - The Beagle proceeded to Charles Island. This archipelago has long been frequented, first by the Bucaniers, and latterly by whalers, but it is only within the last six years that a small colony has been established here. The inhabitants are 
between two and three hundred in number: they are nearly all people of colour, who have been banished for political crimes from the Republic of the Equador, of which Quito is the capital. The settlement is placed about four and a half miles inland, and at a height, probably, of a thousand feet. In the first part of the road we passed through leafless thickets, as in Chatham Island. Higher up the woods gradually became greener, and as soon as we crossed the ridge of the island we were cooled by a fine southerly breeze, and our sight refreshed by a green and thriving vegetation. In this upper region coarse grasses and ferns abound, but there are no tree-ferns: I saw nowhere any member of the Palm family, which is the more singular, as, 360 miles northward, Cocos Island takes its name from the number of cocoa-nuts. The houses are irregularly scattered over a flat space of ground, which is cultivated with sweet potatoes and bananas. It will not easily be imagined how pleasant the sight of black mud was to us, after having been so long accustomed to the parched soil of Peru and northern Chile. The inhabitants, although complaining of poverty, obtain, without much trouble, the means of subsistence. In the woods there are many wild pigs and goats, but the staple article of animal food is supplied by the tortoises. Their numbers have of course been greatly reduced in this island, but the people yet count on two days' lunting giving them food for the rest of the week. It is said that formerly single vessels have taken away as many as seven hundred, and that the ship's company of a frigate some years since brought down in one day two hundred tortoises to the beach.

September 29th.-We doubled the south-west extremity of Albemarle Island, and the next day. 
were nearly becalmed between it and Narborough Island. Both are covered with immense deluges of black, naked lava, which have flowed either over the rims of the great caldrons, like pitch over the rim of a pot in which it has been boiled, or have burst forth from smaller orifices on the flanks; in their descent they have spread over miles of the sea-coast. On both of these islands eruptions are known to have taken place; and in Albemarle we saw a small jet of smoke curling from the summit of one of the great craters. In the evening we anchored in Bank's Cove, in Albemarle Island. The next morning I went out walking. To the south of the broken tuff-crater in which the Beagle was anchored, there was another beautifully symmetrical one of an elliptic form; its longer axis was a little less than a mile, and its depth about 500 feet. At its bottom there was a shallow lake, in the middle of which a tiny crater formed an islet. The day was overpoweringly hot, and the lake looked clear and blue. I hurried down the cindery slope, and, choked with dust, eagerly tasted the water, but, to my sorrow, I found it salt as brine.

The rocks on the coast abounded with great black lizards between three and four feet long, and on the hills an ugly yellowish-brown species was equally common. We saw many of this latter kind, some clumsily running out of our way, and others shuffling into their burrows. I shall presently describe in more detail the habits of both these reptiles. The whole of this northern part of Albemarle Island is miserably sterile.

October Sth.-We arrived at James Island: this island, as well as Charles Island, was long since thus named after our kings of the Stuart line. Mr. Bynoe, myself, and our servants were left here for a week, with provisions and a tent, whilst the 
Beagle went for water. We found here a party of Spaniards, who had been sent from Charles Island to dry fish and to salt tortoise-meat. About six miles inland, and at the height of nearly 2000 feet, a hovel had been built, in which two men lived, who were employed in catching tortoises whilst the others were fishing on the coast. I paid this party two visits, and slept there one night. As in the other islands, the lower region was covered by nearly leafless bushes, but the trees were here of a larger growth than elsewhere, several being two feet, and some even two feet nine inches in diameter. The upper region, being kept damp by the clouds, supports a green and flourishing vegetation. So damp was the ground that there were large beds of a coarse cyperus, in which great numbers of a very small water-rail lived and bred. While staying in this upper region we lived entirely upon tortoise-meat: the breast-plate roasted (as the Gauchos do carne con cuero), with the flesh on it, is very good, and the young tortoises make excellent soup; but otherwise the meat to my taste is indifferent.

One day we accompanied a party of the Spaniards in their whale-boat to a salina, or lake from which salt is procured. After landing, we had a very rough walk over a rugged field of recent lava, which has almost surrounded a tuff-crater, at the bottom of which the salt-lake lies. The water is only three or four inches deep, and rests on a layer of beautifully crystallized white salt. The lake is quite circular, and is fringed with a border of bright green succulent plants; the almost precipitous walls of the crater are clothed with wood, so that the scene was altogether both picturesque and curious. A few years since, the sailors belonging to a sealing-vessel murdered their captain in this 
quiet spot, and we saw his skull lying among the bushes.

During the greater part of our stay of a week the sky was cloudless, and if the trade-wind failed for an hour the heat became very oppressive. On two days the thermometer within the tent stood for some hours at $93^{\circ}$, but in the open air, in the wind and sun, at only $85^{\circ}$. The sand was extremely hot; the thermometer, placed in some of a brown colour, immediately rose to $137^{\circ}$, and how much above that it would have risen I do not know, for it was not graduated any higher. The black sand felt much hotter, so that even in thick boots it was quite disagreeable to walk over it.

The natural history of these islands is eminently curious, and well deserves attention. Most of the organic productions are aboriginal creations, found nowhere else; there is even a difference between the inhabitants of the different islands; yet all show a marked relationship with those of America, though separated from that continent by an open space of ocean between 500 and 600 miles in width. The archipelago is a little world within itself, or, rather, a satellite attached to America, whence it has derived a few stray colonists, and has received the general character of its indigenous productions. Considering the small size of these islands, we feel the more astonished at the number of their aboriginal beings, and at their confined range. Seeing every height crowned with its crater, and the boundaries of most of the lava-streams still distinct, we are led to believe that within a period geologically recent the unbroken ocean was here spread out. Hence, both in space and time, we seem to be brought somewhat near to that great fact-that II,$-\mathrm{N}$ 
mystery of mysteries-the first appearance of new beings on this earth.

Of terrestrial mammals, there is only one which must be considered as indigenous, namely, a mouse (Mus Galapagoensis), and this is confined, as far as I could ascertain, to Chatham Island, the most easterly island of the group. It belongs, as I am informed by Mr. Waterhouse, to a division of the family of mice characteristic of America. At James Island there is a rat sufficiently distinct from the common kind to have been named and described by Mr. Waterhouse; but as it belongs to the old-wortd division of the family, and as this island has been frequented by ships for the last hundred and fifty years, I can hardly doubt that this rat is merely a variety, produced by the new and peculiar climate, food, and soil to which it has been subjected. Although no one has a right to speculate without distinct facts, yet even with respect to the Chatham Island mouse, it should be borne in mind that it may possibly be an American species imported here; for I have seen in a most unfrequented part of the Pampas a native mouse living in the roof of a newly-built hovel, and therefore its transportation in a vessel is not improbable: analogous facts have been observed by Dr. Richardson in North America.

Of land-birds I obtained twenty-six kinds, all peculiar to the group and found nowhere else, with the exception of one lark-like finch from North America (Dolichonyx oryzivorus), which ranges on that continent as far north as $54^{\circ}$, and generally frequents marshes. The other twenty-five birds consist, firstly, of a hawk, curiously intermediate in structure between a buzzard and the American group of carrion-feeding Polybori; and with these latter birds it agrees most closely in every habit 
and even tone of voice. Secondly, there are twr owls, representing the short-eared and white barnowls of Europe. Thirdly, a wren, three tyrant flycatchers (two of them species of Pyrocephalus, one or both of which would be ranked by some ornithologists as only varieties), and a dove-all analogous to, but distinct from, American species. Fourthly, a swallow, which, though differing from the Progne purpurea of both Americas, only in being rather duller coloured, smaller, and slenderer, is considered by Mr. Gould as specifically distinct. Fifthly, there are three species of mocking-thrusha form highly characteristic of America. The remaining land-birds form a most singular group of finches, related to each other in the structure of their beaks, short tails, form of body, and plumage: there are thirteen species, which Mr. Gould has divided into four sub-groups. All these species are peculiar to this archipelago; and so is the whole group, with the exception of one species of the subgroup Cactornis, lately brought from Bow Island, in the Low Archipelago. Of Cactornis, the two species may be often seen climbing about the flowers of the great cactus-trees; but all the other species of this group of finches, mingled together in flocks, feed on the dry and sterile ground of the lower districts. The males of all, or certainly of the greater number, are jet black, and the females (with perhaps one or two exceptions) are brown. The most curious fact is the perfect gradation in the size of the beaks in the different species of Geospiza, from one as large as that of a hawfinch to that of a chaffinch, and (if Mr. Gould is right in including his sub-group, Certhidea, in the main group), even to that of a warbler. The largest beak in the genus Geospiza is shown in Fig. 1, and the smallest in Fig. 3; but, instead of there 


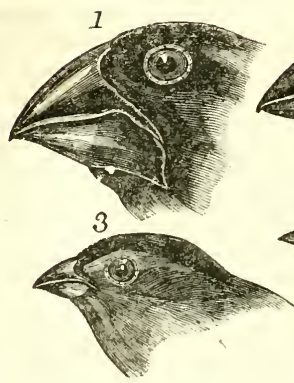

1. Geospiza magnirostris.

3. Geospizaparvula.

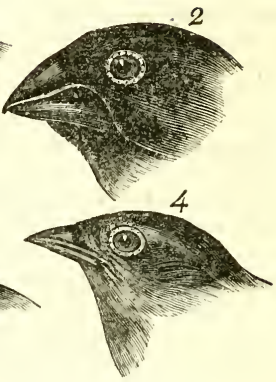

2. Geospiza fortis.

4 Certhidea olivacea.

being only one intermediate species, with a beak of the size shown in Fig. 2, there are no less than six species with insensibly graduated beaks. The beak of the sub-group Certhidea is shown in Fig. 4. The beak of Cactornis is somewhat like that of a starling; and that of the fourth sub-group, Camarhynchus, is slightly parrot-shaped. Seeing this gradation and diversity of structure in one small, intimately-related group of birds, one might really fancy that, from an original paucity of birds in this archipelago, one species had been taken and modified for different ends. In a like manner, it might be fancied that a bird originally a buzzard had been induced here to undertake the office of the carrion-feeding Polybori of the American continent.

Of waders and water-birds I was able to get only eleven kinds, and of these only three (including a rail confined to the damp summits of the islands) are new species. Considering the wandering habits of the galls, I was surprised to find that the spe. 
cies inhabiting these islands is peculiar, but allied to one from the southern parts of South America. The far greater peculiarity of the land-birds, namely, twenty-five out of twenty-six being new species, or at least new races, compared with the waders and web-footed birds, is in accordance with the greater range which these latter orders have in all parts of the world. We shall hereafter see this law of aquatic forms, whether marine or freshwater, being less peculiar at any given point of the earth's surface than the terrestrial forms of the same classes, strikingly illustrated in the shells, and in a lesser degree in the insects of this archipelago.

Two of the waders are rather smaller than the same species brought from other places: the swallow is also smaller, though it is doubtful whether or not it is distinet from its analogue. The two owls, the two tyrant flycatchers (Pyrocephalus), and the dove, are also smaller than the analogous but distinct species to which they are most nearly related; on the other hand, the gull is rather larger. The two owls, the swallow, all three species of mocking-thrush, the dove in its separate colours, though not in its whole plumage, the Totanus, and the gull, are likewise duskier coloured than their analogous species; and in the case of the mocking-thrush and Totanus, than any other species of the two genera. With the exception of a wren with a fine yellow breast, and of a tyrant flycatcher with a scarlet tuft and breast, none of the birds are brilliantly coloured, as might have been expected in an equatorial district. Hence it would appear probable that the same causes which here make the immigrants of some species smaller, make most of the peculiar Galapageian species also smaller, as well as very generally more dusky coloured. All 
the plants have a wretclied, weedy appearance, and I did not see one beautiful flower. The insects, again, are small sized and dull coloured, and, as Mr. Waterhouse informs me, there is nothing in their general appearance which would have led him to imagine that they had come from under the equator. The birds, plants, and insects have a desert character, and are not more brilliantly coloured than those from southerm Patagonia; we may, therefore, conclude that the usual gaudy colouring of the intertropical productions is not related either to the heat or light of those zones, but to some other cause, perhaps to the conditions of existence being generally favourable to life.

We will now turn to the order of reptiles, which gives the most striking character to the zoology of these islands. The species are not numerous, but the numbers of individuals of each species are extraordinarily great. There is one small lizard belonging to a South American genus, and two species (and probably more) of the Amblyrhynchusa genus confined to the Galapagos Islands. There is one snake which is numerous ; it is identical, as I am informed by M. Bibron, with the Psammophis Temminckii from Chile. Of sea-turtle I believe there is more than one species; and of tortoises there are, as we shall presently show, two or three species or races. Of toads and frogs there are none: I was surprised at this, considering how well suited for them the temperate and damp upper woods appeared to be. It recalled to my mind the remark made by Bory St. Vincent,* namely, that

* Voyage aux Quatre Iles d'A frique. With respect to the Sandwich Islands, see Tyerman and Bennett's Journal, vol. i., p. 434. For Mauritius, see Voyage par un Officier, \&c., part i., p. 170. There are no frogs in the Canary Islands (Webb et Berthelot, Hist. Nat. des Iles Canaries). I saw none at St. Jago in the Cape de Verds. There are none at St. Helena. 
none of this family are found on any of the volcanic islands in the great oceans. As far as I can ascertain from various works, this seems to hold good throughout the Pacific, and even in the large islands of the Sandwich Archipelago. Mauritius offers an apparent exception, where I saw the Rana Mascariensis in abundance: this frog is said now to inhabit the Seychelles, Madagascar, and Bourbon; but, on the other hand, Du Bois, in his voyage in 1669, states that there were no reptiles in Bourbon except tortoises; and the Officier du Roi asserts that before 1768 it had been attempted, without success, to introduce frogs into Mauritius-I presume, for the purpose of eating: hence it may be well doubted whether this frog is an aboriginal of these islands. The absence of the frog family in the oceanic islands is the more remarkable when contrasted with the case of lizards, which swarm on most of the smallest islands. Nay this difference not be caused by the greater facility with which the eggs of lizards, protected by calcareous shells, might be transported through salt water, than could the slimy spawn of frogs?

I will first describe the habits of the tortoise (Testudo nigra, formerly called Indica), which has been so frequently alluded to. These animals are found, I believe, on all the islands of the Archipelago; certainly on the greater number. They frequent in preference the high, damp parts, but they likewise live in the lower and arid districts, I have already shown, from the numbers which have been caught in a single day, how very numerous they must be. Some grow to an immense size : Mr. Lawson, an Englishman, and vice-governor of the colony, told us that he had seen several so large that it required six or eight men to lift them from the ground, and that some had afforded as much 
as two hundred pounds of meat. The old males are the largest, the females rarely growing to so great a size: the male can readily be distinguished from the female by the greater length of its tail. The tortoises which live on those islands where there is no water, or in the lower and arid parts of the others, feed chiefly on the succulent cactus. Those which frequent the higher and damp regions eat the leaves of various trees, a kind of berry (called guayavita) which is acid and austere, and likewise a pale-green filamentous lichen (Usnera plicata), that hangs in tresses from the boughs of the trees.

The tortoise is very fond of water, drinking large quantities, and wallowing in the mud. The larger islands alone possess springs, and these are always situated towards the central parts, and at a considerable height. The tortoises, therefore, which frequent the lower districts, when thirsty, are obliged to travel from a long distance. Hence broad and well-beaten paths branch off in every direction from the wells down to the sea-coast; and the Spaniards, by following them up, first discovered the watering-places. When I landed at Chatham Island, I could not imagine what animal travelled so methodically along well-chosen tracks. Near the springs it was a curious spectacle to behold many of these huge creatures, one set eagerly travelling onwards with outstretched necks, and another set returning, after having drunk their fill. When the tortoise arrives at the spring, quite regardless of any spectator, he buries his head in the water above his eyes, and greedily swallows great mouthfuls, at the rate of about ten in a minute. The inhabitants say each animal stays three or four days in the neighbourhood of the water, and then returns to the lower country; but they 
differed respecting the frequency of these visits. The animal probably regulates them according to the nature of the food on which it has lived. It is, however, certain, that tortoises can subsist even on those islands where there is no other water than what falls during a few rainy days in the year.

I believe it is well ascertained that the bladder of the frog acts as a reservoir for the moisture necessary to its existence: such seems to be the case with the tortoise. For some time after a visit to the springs, their urinary bladders are distended with fluid, which is said gradually to decrease in volume, and to become less pure. The inhabitants, when walking in the lower district, and overcome with thirst, often take advantage of this circumstance, and drink the contents of the bladder if full : in one I saw killed the fluid was quite limpid, and had only a very slightly bitter taste. The inhabitants, however, always first drink the water in the pericardium, which is described as being best.

The tortoises, when purposely moving towards any point, travel by night and day, and arrive at their journey's end much sooner than would be expected. 'The inhabitants, from observing marked individuals, consider that they travel a distance of about eight miles in two or three days. One large tortoise, which I watched, walked at the rate of sixty yards in ten minutes, that is 360 yards in the hour, or four miles a day, allowing a little time for it to eat on the road. During the breeding season, when the male and female are together, the male utters a hoarse roar or bellowing, which, it is said, can be heard at the distance of more than a hundred yards. The female never uses her voice, and the male only at these times; so that when the people hear this noise, they know that the two are together. Thev were at this time (October) laying 
their eggs. The female, where the soil is sandy, deposits them together, and covers them up with sand; but where the ground is rocky, she drops them indiscriminately in any hole: Mr. Bynoe found seven placed in a fissure. The egg is white and spherical; one which I measured was seven inches and three eighths in circumference, and therefore larger than a hen's egg. The young tortoises, as soon as they are hatched, fall a prey in great numbers to the carrion-feeding buzzard. The old ones seem generally to die from accidents, as from falling down precipices; at least several of the inhabitants told me that they had never found one dead without some evident cause.

The inhabitants believe that these animals are absolutely deaf; certainly they do not overhear a person walking close behind them. I was always amused, when overtaking one of these great monsters as it was quietly pacing along, to see how suddenly, the instant I passed, it would draw in its head and legs, and, uttering a deep hiss, fall to the ground with a heavy sound, as if struck dead. I frequently got on their backs, and then giving a few raps on the hinder part of their shells, they would rise up and walk away; but I found it very difficult to keep my balance. The flesh of this animal is largely employed, both fresh and salted, and a beautifully clear oil is prepared from the fat. When a tortoise is caught, the man makes a slit in the skin near its tail, so as to see inside its body, whether the fat under the dorsal plate is thick. If it is not, the animal is liberated, and it is said to recover soon from this strange operation. In order to secure the tortoises, it is not sufficient to turn them like turtle, for they are often able to get on their legs again.

There can be little doubt that this tortoise is an 
aboriginal inhabitant of the Galapagos ; for it is found on all, or nearly all the islands, even on some of the smaller ones where there is no water. Had it been an imported species, this would hardly have been the case in a group which has been so little frequented. Moreover, the old Bucaniers found this tortoise in greater numbers even than at present: Wood and Rogers, also, in 1708, say that it is the opinion of the Spaniards that it is found nowhere else in this quarter of the world. It is now widely distributed, but it may be questioned whether it is in any other place an aboriginal. The bones of a tortoise at Mauritius, associated with those of the extinct Dodo, have generally been considered as belonging to this tortoise. If this had been so, undoubtedly it must have been there indigenous; but M. Bibron informs me that he believes that it was distinct, as the species now living there certainly is.

The Amblyrhynchus, a remarkable genus of lizards, is confined to this archipelago: there are two species, resembling each other in general form, one being terrestrial and the other aquatic. This latter species (A. cristatus) was first characterized by $\mathrm{Mr}$. Bell, who well foresaw, from its short, broad head, and strong claws of equal length, that its habits of life would turn out very peculiar, and different from those of its nearest ally, the Iguana. It is extremely common on all the islands throughout the group, and lives exclusively on the rocky sea-beaches, being never found, at least I never saw one, even ten yards in-shore. It is a hideous-looking creature, of a dirty black colour, stupid, and sluggish in its movements. The usual length of a full-grown one is about a yard, but there are some even four feet long; a large one weighed twenty pounds : on the island of Albemarle they seem to grow to a 


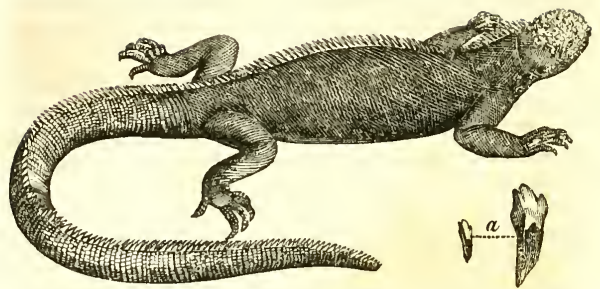

Amblyrhynchus cristatus. $a$, Tooth of natural size, and likewise magnified. greater size than elsewhere. Their tails are flattened sideways, and all four feet partially webbed. They are occasionally seen some hundred yards from the shore, swimming about ; and Captain Collnett, in his Voyage, says, "They go to sea in herds a-fishing, and sun themselves on the rocks, and may be called alligators in miniature." It must not, however; be supposed that they live on fish. When in the water this lizard swims with perfect ease and quickness, by a serpentine movement of its body and flattened tail-the legs being motionless and closely collapsed on its sides. A seaman on board sank one, with a heavy weight attached to it, thinking thus to kill it directly ; but when, an hour afterwards, he drew up the line, it was quite active. Their limbs and strong claws are admirably adapted for crawling over the rugged and fissured masses of lava which everywhere form the coast. In such situations, a group of six or seven of these hideous reptiles may oftentimes be seen on the black rocks, a few feet above the surf, basking in the sun with outstretched legs.

I opened the stomachs of several, and found them largely distended with minced sea-weed (Ulvæ), which grows in thin foliaceous expansions of a 
bright green or a dull red colour. I do not recollect having observed this sea-weed in any quantity on the tidal rocks; and I have reason to believe it grows at the bottom of the sea, at some little distance from the coast. If such be the case, the object of these animals occasionally going out to sea is explained. The stomach contained nothing but the sea-weed. Mr. Bynoe, however, found a piece of a crab in one; but this might have got in accidentally, in the same manner as I have seen a caterpillar, in the midst of some lichen, in the paunch of a tortoise. The intestines were large, as in other herbivorous animals. The nature of this lizard's food, as well as the structure of its tail and feet, and the fact of its having been seen voluntarily swimming out at sea, absolutely prove its aquatic habits; yet there is in this respect one strange anomaly, namely, that when frightened it will not enter the water. Hence it is easy to drive these lizards down to any little point overhanging the sea, where they will sooner allow a person to catch hold of their tails than jump into the water. They do not seem to have any notion of biting; but when much frightened they squirt a drop of fluid from each nostril. I threw one several times as far as I could into a deep pool left by the retiring tide, but it invariably returned in a direct line to the spot where I stood. It swam near the bottom, with a very graceful and rapid movement, and occasianally aided itself over the uneven ground with its feet. As soon as it arrived near the edge, but still being under water, it tried to conceal itself in the tufts of sea-weed, or it entered some crevice. As soon as it thought the danger was past, it crawled out on the dry rocks, and shuffled away as quickly as it could. I several times caught this same lizard by driving it down to a point; and though pos. iI. $-\mathrm{O}$ 
sessed of such perfect powers of diving and swimming, nothing would induce it to enter the water, and as often as I threw it in it returned in the manner above described. Perhaps this singular piece of apparent stupidity may be accounted for by the circumstance that this reptile has no enemy whatever on shore, whereas at sea it must often fall a prey to the numerous sharks. Hence, probably, urged by a fixed and hereditary instinct that the shore is its place of safety, whatever the emergency may be, it there takes refuge.

During our visit (in October) I saw extremely few small individuals of this species, and none, I should think, under a year old. From this circumstance, it seems probable that the breeding season had not then commenced. I asked several of the inhabitants if they knew where it laid its eggs: they said that they knew nothing of its propagation, although well acquainted with the eggs of the land kind-a fact, considering how very common this lizard is, not a little extraordinary.

We will now turn to the terrestrial species (A. Demarlii), with a round tail, and toes without webs. This lizard, instead of being found like the other on all the islands, is confined to the central part of the archipelago, namely, to Albemarle, James, Barrington, and Indefatigable islands. To the southward, in Charles, Hood, and Chatham islands, and to the northward, in Towers, Bindloes, and Abingdon, I neither saw nor heard of any. It would appear as if it had been created in the centre of the archipelago, and thence had been dispersed only to a certain distance. Some of these lizards inhabit the high and damp parts of the islands, but they are much more numerous in the lower and sterile districts near the coast. I cannot give a more forcible proof of their numbers than by stating 
that, when we were left at James Island, we could not for some time find a spot free from their burrows on which to pitch our single tent. Like their brothers the sea-kind, they are ugly animals, of a yellowish orange beneath, and of a brownish red colour above: from their low, facial angle, they have a singularly stupid appearance. They are, perhaps, of a rather less size than the marine species; but several of them weighed between ten and fifteen pounds. In their movements they are lazy and half torpid. When not frightened, they slowly crawl along with their tails and bellies dragging on the ground. They often stop, and doze for a minute or two, with closed eyes and hind legs spread out on the parched soil.

They inhabit burrows, which they sometimes make between fragments of lava, but more generally on level patches of the soft sandstone-like tuff. The holes do not appear to be very deep, and they enter the ground at a small angle; so that, when walking over these lizard-warrens, the soil is constantly giving way, much to the annoyance of the tired walker. This animal, when making its burrow, works alternately the opposite sides of its body. One front leg for a short time scratches up the soil, and throws it towards the hind foot, which is well placed so as to heave it beyond the mouth of the hole. That side of the body being tired, the other takes up the task, and so on alternately. I watched one for a long time, till half its body was buried; I then walked up and pulled it by the tail; at this it was greatly astonished, and soon shuffled up to see what was the matter; and then stared me in the face, as much as to say, "What made you pull my tail ?",

They ieed by day, and do not wander far from their burrows; if frightened, they rush to them with 
a most awkward gait. Except when running down hill, they cannot move very fast, apparently from the lateral position of their legs. 'They are not at all timorous: when attentively watching any one, they curl their tails, and, raising themselves on their front legs, nod their heads vertically, with a quick movement, and try to look very fierce; but, in reality, they are not at all so; if one just stamps on the ground, down go their tails, and off they shuffle as quickly as they can. I have frequently observed small fly-eating lizards, when watching anything, nod their heads in precisely the same manner, but I do not at all know for what purpose. If this Amblyrhynchus is held and plagued with a stick, it will bite it very severely; but I caught many by the tail, and they never tried to bite me. If two are placed on the ground and held together, they will fight and bite each other till blood is drawn.

The individuals, and they are the greater number, which inhabit the lower country, can scarcely taste a drop of water throughout the year; but they consume much of the succulent cactus, the branches of which are occasionally broken off by the wind. I several times threw a piece to two or three of them when together, and it was amusing enough to see them trying to seize and carry it away in their mouths, like so many hungry dogs with a bone. They eat very deliberately, but do not chew their food. The little birds are aware how harmless these creatures are: I have seen one of the thickbilled finches picking at one end of a piece of cactus (which is much relished by all the animals of the lower region), whilst a lizard was eating at the other end; and afterwards the little bird, with the utmost indifference, hopped on the back of the reptile.

I opened the stomachs of several, and found 
them full of vegetable fibres and leaves of different trees, especially of an acacia. In the upper region they live chiefly on the acid and astringent berries of the guayavita, under which trees I have seen these lizards and the huge tortoises feeding together. To obtain the acacia-leaves they crawl up the low, stunted trees, and it is not uncommon to see a pair quietly browsing whilst seated on a branch several feet above the ground. These lizards, when cooked, yield a white meat, which is liked by those whose stomachs soar above all prejudices. Humboldt has remarked, that in intertropical South America, all lizards which inhabit dry regions are esteemed delicacies for the table. The inhabitants state that those which inhabit the upper damp parts drink water, but that the others do not, like the tortoises, travel up for it from the lower sterile country. At the time of our visit the females had within their bodies numerous large, elongated eggs, which they lay in their burrows: the inhabitants seek them for food.

These two species of Amblyrhynchus agree, as I have already stated, in their general structure, and in many of their habits. Neither have that rapid movement so characteristic of the genera Lacerta and Iguana. They are both herbivorous, although the kind of vegetation on which they feed is so very different. Mr. Bell has given the name to the genus from the shortness of the snout; indeed, the form of the mouth may almost be compared to that of the tortoise : one is led to suppose that this is an adaptation to their herbivorous appetites. It is very interesting thus to find a well-characterized genus, having its marine and terrestrial species belonging to so confined a portion of the world. The aquatic species is by far the most remarkable, because it is the only existing lizard which lives on marine vegeII. 
table productions. As I at first observed, these islands are not so remarkable for the number of the species of reptiles as for that of the individuals; when we remember the well-beaten paths made by the thousands of huge tortoises-the many turtles-the great warrens of the terrestrial Amblyrhynchus - and the groups of the marine species basking on the coast-rocks of every island, we must admit that there is no other quarter of the world where this Order replaces the herbivorous mammalia in so extraordinary a manner. The geologist, on hearing this, will probably refer back in his mind to the Secondary epochs, when lizards, some herbivorous, some carnivorous, and of dimensions comparable only with our existing whales, swarmed on the land and in the sea. It is, therefore, worthy of his observation, that this archipelago, instead of possessing a humid climate and rank vegetation, cannot be considered otherwise than extremely arid, and, for an equatorial region, remarkably temperate.

To finish with the zoology : the fifteen kinds of sea-fish which I procured here are all new species; they belong to twelve genera, all widely distributed, with the exception of Prionotus, of which the four previously-known species live on the eastern side of America. Of land-shells I collected sixteen kinds (and two marked varieties), of which, with the exception of one Helix found at Tahiti, all are peculiar to this archipelago: a single fresh-water shell (Paludina) is common to Tahiti and Van Diemen's Land. Mr. Cuming, before our voyage, procured here ninety species of sea-shells, and this does not include several species not yet specifically examined, of Trochus, Turbo, Monodonta, and Nassa. He has been kind enough to give me the following interesting results: of the ninety shells, 
no less than forty-seven are unknown elsewhere : a wonderful fact, considering how widely distributed sea-shells generally are. Of the forty-three shells found in other parts of the world, twenty-five inhabit the western coast of America, and of these eight are distinguishable as varieties; the remaining eighteen (including one variety) were found by Mr. Cuming in the Low Archipelago, and some of them also at the Philippines. This fact of shells from islands in the central parts of the Pacific occurring here deserves notice, for not one single sea-shell is known to be common to the islands of that ocean and to the west coast of America. The space of open sea running north and south off the west coast separates two quite distinct conchological provinces; but at the Galapagos Archipelago we have a halting-place, where many new forms have been created, and whither these two great conchological provinces have each sent several colonists. The American province has also sent here representative species, for there is a Galapageian species of Monoceros, a genus only found on the west coast of America ; and there are Galapageian species of Fissurella and Cancellaria, genera common on the west coast, but not found (as I am informed by Mr. Cuming) in the central islands of the Pacific. On the other hand, there are Galapageian species of Oniscia and Stylifer, genera common to the West Indies and to the Chinese and Indian seas, but not found either on the west coast of America or in the central Pacific. I may here add, that after the comparison by Messrs. Cuming and Hinds of about 2000 shells from the eastern and western coasts of America, only one single shell was found in common, namely, the Purpura patula, which inhabits the West Indies, the coast of Panama, and the Galapagos. We have, there- 
fore, in this quarter of the world, three great conchological sea-provinces, quite distinct, though surprisingly near each other, being separated by long north and south spaces either of land or of open sea.

I took great pains in collecting the insects, but, excepting Tierra del Fuego, I never saw in this respect so poor a country. Even in the upper and damp region I procured very few, excepting some minute Diptera and Hymenoptera, mostly of common mundane forms. As before remarked, the insects, for a tropical region, are of very small size and dull colours. Of beetles I collected twentyfive species (excluding a Dermestes and Corynetes imported, wherever a ship touches); of these, two belong to the Harpalidæ, two to the Hydrophilidæ, nine to three families of the Heteromera, and the remaining twelve to as many different families. This circumstance of insects (and I may add plants), where few in number, belonging to many different families, is, I believe, very general. Mr. Waterhouse, who has published* an account of the insects of this archipelago, and to whom I am indebted for the above details, informs me that there are sereral new genera; and that of the genera not new, one or two are American, and the rest of mundane distribution. With the exception of a wood-feeding Apate, and of one or probably two water-beetles from the American continent, all the species appear to be new.

The botany of this group is fully as interesting as the zoology. Dr. J. Hooker will soon publish in the "Linnean Transactions" a full account of the Flora, and I am much indebted to him for the following details. Of flowering plants there are, as far as at present is known, 185 species, and 40

* Ann. and Mag. of Nat. Hist., vol. xvi., p. 19. 
cryptogamic species, making together 225 ; of this number I was fortunate enough to bring home 193. Of the flowering plants, 100 are new species, and are probably confined to this archipelago. Dr. Hooker conceives that, of the plants not so confined, at least 10 species found near the cultivated ground at Charles Island have been imported. It is, I think, surprising that more American species have not been introduced naturally, considering that the distance is only between 500 and 600 miles from the continent; and that (according to Collnett, p. 58) drift-wood, bamboos, canes, and the nuts of a palm, are often washed on the southeastern shores. The proportion of 100 flowering plants out of 185 (or 175 excluding the imported weeds) being new, is sufficient, I conceive, to make the Galapagos Archipelago a distinct botanical province; but this Flora is not nearly so peculiar as that of St. Helena, nor, as I am informed by Dr. Hooker, of Juan Fernandez. The peculiarity of the Galapageian Flora is best shown in certain families : thus, there are 21 species of Compositæ, of which 20 are peculiar to this archipelago; these belong to twelve genera, and of these genera no less than ten are confined to the archipelago! Dr. Hooker informs me that the Flora has an undoubted Western American character, nor can he detect in it any affinity with that of the Pacific. If, therefore, we except the eighteen marine, the one freshwater, and one land-shell, which have apparently come here as colonists from the central islands of the Pacific, and likewise the one distinct Pacific species of the Galapageian group of finches, we see that this archipelago, though standing in the Pacific Ocean, is zoologically part of America.

If this character were owing merely to immigrants from America, there would be little remark- 
able in it; but we see that a vast majority of all the land animals, and that more than half of the flowering plants, are aboriginal productions. It was most striking to be surrounded by new birds, new reptiles, new shells, new insects, new plants, and yet, by innumerable trifling details of structure, and even by the tones of voice and plumage of the birds, to have the temperate plains of Patagonia, or the hot, dry deserts of Northern Chile, vividly brought before my eyes. Why, on these small points of land, which, within a late geological period, must have been covered by the ocean, which are formed of basaltic lava, and therefore differ in geological character from the American continent, and which are placed under a peculiar climate-why were their aboriginal inhabitants associated, I may add, in different proportions, both in kind and number, from those on the continent, and therefore acting on each other in a different manner-why were they created on different types of organization? It is probable that the islands of the Cape de Verd group resemble, in all their physical conditions, far more closely the Galapagos Islands than these latter physically resemble the coast of America; yet the aboriginal inhabitants of the two groups are totally unlike, those of the Cape de Verd Islands bearing the impress of Africa, as the inhabitants of the Galapagos Archipelago are stamped with that of America.

I have not as yet noticed by far the most remarkable feature in the natural history of this archipelago; it is, that the different islands, to a considerable extent, are inhabited by a different set of beings. My attention was first called to this fact by the vice-governor, Mr. Lawson, declaring that the tortoises differed from the different islands, and 
that he could with certainty tell from which island any one was brought. I did not for some time pay sufficient attention to this statement, and I had already partially mingled together the collections from two of the islands. I never dreamed that islands about fifty or sixty miles apart, and most of them in sight of each other, formed of precisely the same rocks, placed under a quite similar climate, rising to a nearly equal height, would have been differently tenanted; but we shall soon see that this is the case. It is the fate of most voyagers, no sooner to discover what is most interesting in any locality, than they are hurried from it ; but I ought, perhaps, to be thankful that I obtained sufficient materials to establish this most remarkable fact in the distribution of organic beings.

The inhabitants, as I have said, state that they can distinguish the tortoises from the different islands, and that they differ not only in size, but in other characters. Captain Porter has described* those from Charles and from the nearest island to it, namely, Hood Island, as having their shells in front thick and turned up like a Spanish saddle, whilst the tortoises from James Island are rounder, blacker, and have a better taste when cooked. M. Bibron, moreover, informs me that he has seen what he considers two distinct species of tortoise from the Galapagos, but he does not know from which islands. The specimens that I brought from three islands were young ones, and probably owing to this cause neither Mr. Gray nor myself could find in them any specific differences. I have remarked that the marine Amblyrhynchus was larger at Albemarle Island than elsewhere; and M. Bibron informs me that he has seen two distinct aquatic species of this genus; so that the different * Voyage in the U. S. ship Essex, vol. i., p. 215. 
islands probably have their representative species or races of the Amblyrhynchus, as well as of the tortoise. My attention was first thoroughly aroused by comparing together the numerous specimens, shot by myself and several other parties on board, of the mocking-thrushes, when, to my astonishment, I discovered that all those from Charles Island belonged to one species (Mimus trifasciatus); all from Albemarle Island to M. parvulus; and all from James and Chatham Islands (between which two other islands are situated as connecting links) belonged to M. melanotis. These two latter species are closely allied, and would, by some ornithologists, be considered as only well-marked races or varieties; but the Mimus trifasciatus is very distinct. Unfortunately, most of the specimens of the finch tribe were mingled together; but I have strong reasons to suspect that some of the species of the sub-group Geospiza are confined to separate islands. If the different islands have their representatives of Geospiza, it may help to explain the singularly large number of the species of this sub-group in this one small archipelago, and as a probable consequence of their numbers, the perfectly graduated series in the size of their beaks. Two species of the sub-group Cactornis, and two of Camarhynchus, were procured in the archipelago; and of the numerous specimens of these two sub-groups shot by four collectors at James Island, all were found to belong to one species of each; whereas the numerous specimens shot either on Chatham or Charles Island (for the two sets were mingled together) all belonged to the two other species: hence we may feel almost sure that these islands possess their representative species of these two sub-groups. In land-shells this law of distribution does not appear to hold good. In my very 
small collection of insects, Mr. Waterhouse remarks that of those which were ticketed with their locality, not one was common to any two of the islands.

If we now turn to the Flora, we shall find the aboriginal plants of the different islands wonderfully different. I give all the following results on the high authority of my friend Dr.J.Hooker. I may premise that I indiscriminately collected everything in flower on the different islands, and fortunately kept my collections separate. Too much confidence, hwwever, must not be placed in the proportional results, as the small collections brought home by some other naturalists, though in some respects confirming the results, plainly show that much remains to be done in the botany of this group: the Leguminosæ, moreover, have as yet been only approximately worked out :

\begin{tabular}{|l|c|c|c|c|c|}
\hline \multicolumn{1}{|c|}{ Name of Island. } & $\begin{array}{c}\text { Total } \\
\text { No. of } \\
\text { Species. }\end{array}$ & $\begin{array}{c}\text { No of Spe- } \\
\text { cies found } \\
\text { in other } \\
\text { parts of the } \\
\text { world. }\end{array}$ & $\begin{array}{c}\text { No. of } \\
\text { Species con- } \\
\text { fined to the } \\
\text { Galapagos } \\
\text { Archipelago. }\end{array}$ & $\begin{array}{c}\text { No. } \\
\text { confined } \\
\text { to the } \\
\text { one } \\
\text { island. }\end{array}$ & $\begin{array}{c}\text { No. of Species con- } \\
\text { ined to the Galapa- } \\
\text { gos Archipelago, } \\
\text { but found on more } \\
\text { than the one island. }\end{array}$ \\
\hline James lsland & 71 & 33 & 38 & 30 & 8 \\
Albemarle lsland & 46 & 18 & 26 & 22 & 4 \\
Chatham Island & 32 & 16 & 16 & 12 & 4 \\
Charles Island & 68 & $39 *$ & 29 & 21 & 8 \\
\hline
\end{tabular}

* Or 29 , if the probably imported plants be subtracted.

Hence we have the truly wonderful fact, that in James Island, of the thirty-eight Galapageian plants, or those found in no other part of the world, thirty are exclusively confined to this one island; and in Albemarle Island, of the twenty-six aboriginal Galapageian plants, twenty-two are confined to this one island, that is, only four are at present known to grow in the other islands of the archipelago; and so on, as shown in the above table, with the plants from Chatham and Charles Islands. This fact will, perhaps, be rendered even more striking, by giving a few illustrations: thus, Scalesia, a reII.-P 
markably arborescent genus of the Compositæ, is confined to the archipelago. It has six species: one from Chatham, one from Albemarle, one from Charles Island, two from James Island, and the sixth from one of the three latter islands, but it is not known from which : not one of these six species grows on any two islands. Again, Euphorbia, a mundane or widely-distributed genus, has here eight species, of which seven are confined to the archipelago, and not one found on any two islands; Acalypha and Borreria, both mundane genera, have respectively six and seven species, none of which have the same species on two islands, with the exception of one Borreria, which does occur on two islands. The species of the Compositæ are particularly local, and Dr. Hooker has furnished me with several other most striking illustrations of the difference of the species on the different islands. He remarks that this law of distribution holds good both with those genera confined to the archipelago and those distributed in other quarters of the world: in like manner, we have seen that the different islands have their proper species of the mundane genus of tortoise, and of the widely-distributed American genus of the mocking-thrush, as well as of two of the Galapageian sub-groups of finches, and almost certainly of the Galapageian genus Amblyrhynchus.

The distribution of the tenants of this archipelago would not be nearly so wonderful, if, for instance, one island had a mocking-thrush, and a second island some other quite distinct genus; if one island had its genus of lizard, and a second island another distinct genus, or none whatever; or if the different islands were inhabited, not by representative species of the same genera of plants, but by totally different genera, as does to a certain extent 
hold good; for, to give one instance, a large berrybearing tree at James Island has no representative species in Charles Island. But it is the circumstance that several of the islands possess their own species of the tortoise, mocking-thrush, finches, and numerous plants, these species having the same general habits, occupying analogous situations, and obviously filling the same place in the natural economy of this archipelago, that strikes me with wonder. It may be suspected that some of these representative species, at least in the case of the tortoise and of some of the birds, may hereafter prove to be only well-marked races; but this would be of equally great interest to the philosophical naturalist. I have said that most of the islands are in sight of each other: I may specify that Charles Island is fifty miles from the nearest part of Chatham Island, and thirty-three miles from the nearest part of Albemarle Island. Chatham Island is sixty miles from the nearest part of James Island, but there are two intermediate islands between them which were not visited by me. James Island is only ten miles from the nearest part of Albemarle Island, but the two points where the collections were made are thirty-two miles apart. I must repeat, that neither the nature of the soil, nor height of the land, nor the climate, nor the general character of the associated beings, and therefore their action one on another, can differ much in the different islands. If there be any sensible difference in their climates, it must be between the windward group (namely, Charles and Chatham Islands) and that to leeward; but there seems to be no corresponding difference in the productions of these two halves of the archipelago.

The only light which I can throw on this remarkable difference in the inhabitants of the differ- 
ent islands is, that very strong currents of the sea, running in a westerly and W.N.W. direction, must separate, as far as transportal by the sea is concerned, the southern islands from the northern ones; and between these northern islands a strong N.W. current was observed, which must effectually separate James and Albemarle Islands. As the archipelago is free to a most remarkable degree from gales of wind, neither the birds, insects, nor lighter seeds would be blown from island to island. And lastly, the profound depth of the ocean between the islands, and their apparently recent (in a geological sense) volcanic origin, render it highly unlikely that they were ever united; and this, probably, is a far more important consideration than any other, with respect to the geographical distribution of their inlrabitants. Reviewing the facts here given, one is astonished at the amount of creative force, if such an expression may be used, displayed on these small, barren, and rocky islands, and still more so at its diverse yet analogous action on points so near each other. I have said that the Galapagos Archipelago might be called a satellite attached to America, but it should rather be called a group of satellites, physically similar, organically distinct, yet intimately related to eảch other, and all related in a marked, though much lesser degree, to the great American continent.

I will conclude my description of the natural history of these islands by giving an account of the extreme tameness of the birds.

This disposition is common to all the terrestrial species; namely, to the mocking-thrushes, the finches, wrens, tyrant flycatchers, the dove, and carrion-buzzard. All of them often approached. 
sufficiently near to be killed with a switch, and sometimes, as I myself tried, with a cap or hat. A gun is here almost superfluous; for with the muzzle I pushed a hawk off the branch of a tree. One day, whilst lying down, a mocking-thrush alighted on the edge of a pitcher, made of the shell of a tortoise, which I held in my hand, and began very quietly to sip the water; it allowed me to lift it from the ground whilst seated on the vessel: I often tried, and very nearly succeeded, in catching these birds by their legs. Formerly the birds appear to have been even tamer than at present. Cowley (in the year 1684) says, that the "turtledoves were so tame, that they would often alight upon our hats and arms, so as that we could take them alive: they not fearing man, until such time as some of our company did fire at them, whereby they were rendered more shy." Dampier also, in the same year, says that a man in a morning's walk might kill six or seven dozen of these doves. At present, although certainly very tame, they do not alight on people's arms, nor do they suffer themselves to be killed in such large numbers. It is surprising that they have not become wilder; for these islands during the last hundred and fifty years have been frequently visited by bucaniers and whalers; and the sailors, wandering through the woods in search of tortoises, always take cruel delight in knocking down the little birds.

These birds, although now still more persecuted, do not readily become wild: in Charles Island, which had then been colonized about six years, I saw a boy sitting by a well with a switch in his hand, with which he killed the doves and finches as they came to drink. He had already procured a little heap of them for his dinner; and he said that he had constantly been in the habit of waiting $\mathrm{P} 2$ 
by this well for the same purpose. It would appear that the birds of this archipelago, not having as yet learned that man is a more dangerous animal than the tortoise or the Amblyrhynchus, disregard him, in the same mamner as in England shy birds, such as magpies, disregard the cows and horses grazing in our fields.

The Falkland Islands offer a second instance of birds with a similar disposition. The extraordinary tameness of the little Opetiorhynchus has been remarked by Pernety, Lesson, and other voyagers. It is not, however, peculiar to that bird : the Polyborus, snipe, upland and lowland goose, thrush, bunting, and even some true hawks, are all more or less tame. As the birds are so tame there, where foxes, hawks, and owls occur, we may infer that the absence of all rapacious animals at the Galapagos is not the cause of their tameness here. The upland geese at the Falklands show, by the precaution they take in building on the islets, that they are aware of their danger from the foxes, but they are not, by this, rendered wild towards man. This tameness of the birds, especially of the waterfowl, is strongly contrasted with the habits of the same species in Tierra del Fuego, where for ages past they have been persecuted by the wild inlabitants. In the Falklands, the sportsman may sometimes kill more of the upland geese in one day than he can carry home, whereas in Tierra del Fuego it is nearly as difficult to kill one as it is in England to shoot the common wild goose.

In the time of Pernety (1763), all the birds there appear to have been much tamer than at present; he states that the Opetiorhynchus would almost perch on his finger, and that with a wand he killed ten in half an hour. At that period the birds must have been about as tame as they now are at the 
Galapagos. They appear to have learned caution more slowly at these latter islands than at the Falklands, where they have had proportionate means of experience ; for, besides frequent visits from vessels, those islands have been at intervals colonized during the entire period. Even formerly, when all the birds were so tame, it was impossible, by Pernety's account, to kill the black-necked swana bird of passage, which probably brought with it the wisdom learned in foreign countries.

I may add that, according to Du Bois, all the birds at Bourbon in 1571-72, with the exception of the flamingoes and geese, were so extremely tame, that they could be caught by the hand, or killed in any number with a stick. Again, at Tristan d'Acunha, in the Atlantic, Carmichael* states, that the only two land-birds, a thrush and a bunting, were "so tame as to suffer themselves to be caught with a hand-net." From these several facts, we may, I think, conclude, first, that the wildness of birds with regard to man is a particular instinct directed against him, and not dependant on any general degree of caution arising from other sources of danger; secondly, that it is not acquired by individual birds in a short time, even when much persecuted, but that in the course of successive generations it becomes hereditary. With domesticated animals we are accustomed to see new

* Linn. Trans., vol. xii., p. 496. The most anomalous fact on this subject which I have met with is the wildness of the small birds in the Arctic parts of North America (as described by Richardson, Fauna Bor., vol. ii., p. 332), where they are said never to be persecuted. This case is the more strange, because it is asserted that some of the same species in their winter-quarters in the United States are tame. There is much, as Dr. Richardson well remarks, utterly inexplicable connected with the different degrees of shyness and care with which birds conceal their nests. How strange it is that the English wood-pigeon, generally so wild a bird, should very frequently rear its young in shrubberies close to houses! 
mental habits or instincts acquired and rendered hereditary, but with animals in a state of nature it must always be most difficult to discover instances of acquired hereditary knowledge. In regard to the wildness of birds towards man, there is no way of accounting for it except as an inherited habit: comparatively few young birds, in any one year, have been injured by man in England, yet almost all, even nestlings, are afraid of him; many individuals, on the other hand, both at the Galapagos and at the Falklands, have been pursued and injured by man, but yet have not learned a salutary dread of him. We may infer from these facts what havoc the introduction of any new beast of prey must cause in a country before the instincts of the indigenous inhabitants have become adapted to the stranger's craft or power.

\section{CHAPTER VI.}

Pass through the Low Archipelago-Tahiti-Aspect-Vegetation on the Mountains-View of Eimeo-Excursion into the Interior-Profound Ravines-Succession of Waterfalls-Number of wild useful Plants-Temperance of the Inhabitants--Their Moral State-Parliament Convened-New Zealand-Bay of Islands-Hippahs-Excursion to Waimate-Missionary Establishment-English Weeds now run wild-Waiomio-Funeral of a New Zealand Woman-Sail for Australia.

TAHITI AND NEW ZEALAND.

October 20th.-The survey of the Galapagos Archipelago being concluded, we steered towards Tahiti and commenced our long passage of 3200 miles. In the course of a few days we sailed out of the gloomy and clouded ocean-district which extends during the winter far from the coast of South America. We then enjoyed bright and clear weather, while running pleasantly along at 
the rate of 150 or 160 miles a day before the steady trade-wind. The temperature in this more central part of the Pacific is higher than near the American shore. The thermometer in the poop cabin, by night and by day, ranged between $80^{\circ}$ and $83^{\circ}$, which feels very pleasant; but with one degree or two higher, the heat becomes oppressive. We passed through the Low or Dangerous Archipelago, and saw several of those most curious rings of coral land, just rising above the water's edge, which have been called Lagoon Islands. A long and brilliantly-white beach is capped by a margin of green vegetation; and the strip, looking either way, rapidly narrows away in the distance, and sinks beneath the horizon. From the mast-head a wide expanse of smooth water can be seen within the ring. These low, hollow coral islands bear no proportion to the vast ocean out of which they abruptly rise, and it seems wonderful that such weak invaders are not overwhelmed by the all-powerful and never-tiring waves of that great sea miscalled the Pacific.

November 15th.-At daylight, Tahiti, an island which must forever remain classical to the voyager in the South Sea, was in view. At a distance the appearance was not attractive. The luxuriant vegetation of the lower part could not yet be seen, and as the clouds rolled past, the wildest and most precipitous peaks showed themselves towards the centre of the island. As soon as we anchored in Matavai Bay we were surrounded by canoes. This was our Sunday, but the Monday of Tahiti : if the case had been reversed, we should not have received a single visit; for the injunction not to launch a canoe on the Sabbath is rigidly obeyed. After dinner we landed to enjoy all the delights produced by the first impressions of a new country, II. 
and that country the charming Tahiti. A crowd of men, women, and children was collected on the memorable Point $\mathrm{V}$ enus, ready to receive us with laughing, merry faces. They marshalled us towards the house of Mr. Wilson, the missionary of the district, who met us on the road, and gave us a very friendly reception. After sitting a short time in his house, we separated to walk about, but returned there in the evening.

The land capable of cultivation is scarcely in any part more than a fringe of low, alluvial soil, accumulated round the base of the mountains, and protected from the waves of the sea by a coral reef, which encircles the entire line of coast. Within the reef there is an expanse of smooth water, like that of a lake, where the canoes of the natives can ply with safety, and where ships anchor. The low land which comes down to the beach of coral-sand is covered by the most beautiful productions of the intertropical regions. In the midst of bananas, orange, cocoa-nut, and bread-fruit trees, spots are cleared where yams, sweet potatoes, the sugarcane, and pine-apples are cultivated. Even the brushwood is an imported fruit-tree, namely, the guava, which, from its abundance, has become as noxious as a weed. In Brazil I have often admired the varied beauty of the bananas, palms, and orange-trees contrasted together; and here we also have the bread-fruit, conspicuous from its large, glossy, and deeply-digitated leaf. It is admirable to behold groves of a tree, sending forth its branches with the vigour of an English oak, loaded with large and most nutritious fruit. However seldom the usefulness of an object can account for the pleasure of beholding it, in the case of these beautiful woods, the knowledge of their high productiveness no doubt enters largely into the feeling of 
admiration. The little winding paths, cool from the surrounding shade, led to the scattered houses, the owners of which everywhere gave us a cheerful and most hospitable reception.

I was pleased with nothing so much as with the inhabitants. There is a mildness in the expression of their countenances which at once banishes the idea of a savage, and an intelligence which shows that they are advancing in civilization. The common people, when working, keep the upper part of their bodies quite naked; and it is then that the Tahitians are seen to advantage. They are very tall, broad shouldered, athletic, and well proportioned. It has been remarked, that it requires little habit to make a dark skin more pleasing and natural to the eye of a European than his own colour. A white man bathing by the side of a Tahitian was like a plant bleached by the gardener's art compared with a fine, dark green one growing vigorously in the open fields. Most of the men are tattooed, and the ornaments follow the curvature of the body so gracefully, that they have a very elegant effect. One common pattern, varying in its details, is somewhat like the crown of a palm-tree. It springs from the central line of the back, and gracefully curls round both sides. The simile may be a fanciful one, but I thought the body of a man thus ornamented was like the trunk of a noble tree embraced by a delicate creeper.

Many of the elder people had their feet covered with small figures, so placed as to resemble a sock. This fashion, however, is partly gone by, and has been succeeded by others. Here, although fashion is far from immutable, every one must abide by that prevailing in his youth. An old man has thus his age forever stamped on his body, and he cannot assume the airs of a young dandy. The women 
are tattooed in the same manner as the men, and very commonly on their fingers. One unbecoming fashion is now almost universal: namely, shaving the hair from the upper part of the head, in a circular form, so as to leare only an outer ring. The missionaries have tried to persuade the people to change this lrabit; but it is the fashion, and that is a sufficient answer at Tahiti, as well as at Paris. I was much disappointed in the personal appearance of the women: they are far inferior in every respect to the men. The custom of wearing a white or scarlet flower in the back of the head, or through a small hole in each ear, is pretty. A crown of woven cocoa-nut leaves is also worn as a shade for the eyes. The women appear to be in greater want of some becoming costume even than the men.

Nearly all the natives understand a little English - that is, they know the names of common things; and by the aid of this, together with signs, a lame sort of conversation could be carried on. In returning in the evening to the boat, we stopped to witness a very pretty scene. Numbers of children were playing on the beach, and had lighted bonfires, which illumined the placid sea and surrounding trees ; others, in circles, were singing Tahitian verses. We seated ourselves on the sand, and joined their party. The songs were impromptu, and I believe related to our arrival: one little girl sang a line, which the rest took up in parts, forming a very pretty chorus. The whole scene made us unequivocally aware that we were seated on the shores of an island in the far-famed South Sea.

17th.-This day is reckoned in the log-book as Tuesday the 17th, instead of Monday the 16th, owing to our, so far, successful chase of the sun. Before breakfast the ship was hemmed in by a 
flotilla of canoes; and when the natives were allowed to come on board, I suppose there could not have been less than two hundred. It was the opinion of every one that it would have been difficult to have picked out an equal number from any other nation who would have given so little trouble. Everybody brought something for sale : shells were the main article of trade. The Tahitians now fully understand the value of money, and prefer it to old clothes or other articles. The various coins, however, of English and Spanish denomination puzzle them, and they never seemed to think the small silver quite secure until changed into dollars. Some of the chiefs have accumulated considerable sums of money. One chief, not long since, offered 800 dollars (about $£ 160$ sterling) for a small vessel; and frequently they purchase whale-boats and horses at the rate of from 50 to 100 dollars.

After breakfast I went on shore, and ascended the nearest slope to a height of between two and three thousand feet. The outer mountains are smooth and conical, but steep; and the old volcanic rocks, of which they are formed, have been cut through by many profound ravines, diverging from the central broken parts of the island to the coast. Having crossed the narrow low girt of inhabited and fertile land, I followed a smooth steep ridge between two of the deep ravines. The vegetation was singular, consisting almost exclusively of small dwarf ferns, mingled, higher up, with coarse grass; it was not very dissimilar from that on some of the Welsh hills, and this, so close above the orchard of tropical plants on the coast, was very surprising. At the highest point which I reached, trees again appeared. Of the three zones of comparative luxuriance, the lower one owes its moisture, and therefore fertility, to its flatness; for, beII. $-Q$ 
ing scarcely raised above the level of the sea, the water from the higher land drains away slowly. The intermediate zone does not, like the upper one, reach into a damp and clondy atmosphere, and therefore remains sterile. The woods in the upper zone are very pretty, tree-ferns replacing the cocoa-nuts on the coast. It must not, however, be supposed that these woods at all equal in splendour the forests of Brazil. The vast number of productions which characterize a continent cannot be expected to occur in an island.

From tho highest point which I attained there was a good view of the distant island of Eimeo, dependant on the same sovereign with Tahiti. On the lofty and broken pinnacles, white massive clouds were piled up, which formed an island in the blue sky, as Eimeo itself did in the blue ocean. The island, with the exception of one small gateway, is completely encircled by a reef. At this distance, a narrow but well-defined brilliantly white line was alone visible, where the waves first encountered the wall of coral. The mountains rose abruptly out of the glassy expanse of the lagoon included within this narrow white line, outside which the heaving waters of the ocean were dark coloured. The view was striking: it may aptly be compared to a framed engraving, where the frame represents the breakers, the marginal paper the smooth lagoon, and the drawing the island itself. When in the evening I descended from the mountain, a man, whom I had pleased with a trifling gift, met me, bringing with him hot roasted bananas, a pineapple, and cocoa-nuts. After walking under a burning sun, I do not know anything more delicious than the milk of a young cocoa-nut. Pineapples are here so abundant that the people eat them in the same wasteful manner as we might 
turnips. They are of an excellent flavour-perhaps even better than those cultivated in England; and this, I believe, is the highest compliment which can be paid to any fruit. Before going on board, $\mathrm{Mr}$. Wilson interpreted for me to the Tahitian who had paid me so adroit an attention, that I wanted him and another man to accompany me on a short excursion into the mountains.

18th.- In the morning I came on shore early, bringing with me some provisions in a bag, and two blankets for myself and servant. These were lashed to each end of a long pole, which was alterternately carried by my Tahitian companions on their shoulders. These men are accustomed thus to carry, for a whole day, as much as fifty pounds at each end of their poles. I told my guides to provide themselves with food and clothing; but they said that there was plenty of food in the mountains, and for clothing, that their skins were sufficient. Our line of march was the valley of Tia-auru, down which a river flows into the sea by Point Venus. This is one of the principa! streams in the island, and its source lies at the base of the loftiest central pinnacles, which rise to a height of about 7000 feet. The whole island is so mountainous that the only way to penetrate into the interior is to follow up the valleys. Our road, at first, lay through woods which bordered each side of the river; and the glimpses of the lofty central peaks, seen as through an avenue, with here and there a waving cocoa-nut tree on one side, were extremely picturesque. The valley soon began to narrow, and the sides to grow lofty and more precipitous. After having walked between three and four hours, we found the width of the ravine scarcely exceeded that of the bed of the stream. On each hand the walls were nearly 
vertical; yet, from the soft nature of the volcanic strata, trees and a rank vegetation sprung from every projecting ledge. These precipices must have been some thousand feet high; and the whole formed a mountain gorge far more magnificent than anything which I had ever before beheld. Until the midday sun stood vertically over the ravine, the air felt cool and damp, but now it became very sultry. Shaded by a ledge of rock, beneath a façade of columnar lava, we ate our dinner. My guides had already procured a dish of small fish and fresh-water prawns. They carried with them a small net stretched on a hoop; and where the water was deep and in eddies, they dived, and, like otters, with their eyes open, followed the fish into holes and corners, and thus caught them.

The Tahitians have the dexterity of amphibious animals in the water. An anecdote mentioned by Ellis shows how much they feel at home in this element. When a horse was landing for Pomarre in 1817 , the slings broke, and it fell into the water: immediately the natives jumped overboard, and by their cries and vain efforts at assistance almost drowned it. As soon, however, as it reached the shore, the whole population took to flight, and tried to hide themselves from the man-carrying pig, as they christened the horse.

A little higher up, the river divided itself into three little streams. The two northern ones were impracticable, owing to a succession of waterfalls which descended from the jagged summit of the highest mountain; the other, to all appearance, was equally inaccessible, but we managed to ascend it by a most extraordinary road. The sides of the valley were here nearly precipitous; but, as frequently happens with stratified rocks, small ledges 
projected, which were thickly covered by wild bananas, liliaceous plants, and other luxuriant productions of the tropics. The Tahitians, by climbing amongst these ledges, searching for fruit, had discovered a track by which the whole precipice could be scaled. The first ascent from the valley was very dangerous, for it was necessary to pass a steeply-inclined face of naked rock by the aid of ropes which we brought with us. How any person discovered that this formidable spot was the only point where the side of the mountain was practicable, I cannot imagine. We then cautiously walked along one of the ledges till we came to one of the three streams. This ledge formed a flat spot, above which a beautiful cascade, some hundred feet in height, poured down its waters, and beneath, another high cascade fell into the main stream in the valley below. From this cool and shady recess we made a circuit to avoid the overhanging waterfall. As before, we followed little projecting ledges, the danger being partly concealed by the thickness of the vegetation. In passing from one of the ledges to another, there was a vertical wall of rock. One of the Tahitians, a fine, active man, placed the trunk of a tree against this, climbed up it, and then, by the aid of crevices, reached the summit. He fixed the ropes to a projecting point, and lowered them for our dog and luggage, and then we clambered up ourselves. Beneath the ledge on which the dead tree was placed, the precipice must have been five or six hundred feet deep; and if the abyss had not been partly concealed by the overhanging ferns and lilies, my head would have turned giddy, and nothing should have induced me to have attempted it. We continued to ascend, sometimes along ledges, and sometimes along knife-edged ridges, having 
on each hand profound ravines. In the Cordillera I have seen mountains on a far grander scale, but for abruptness nothing at all comparable with this. In the evening we reached a flat little spot on the banks of the same stream, which we had continued to follow, and which descends in a chain of waterfalls : here we bivouacked for the night. On each side of the ravine there were great beds of the mountain-banana, covered with ripe fruit. Many of these plants were from twenty to twenty-five feet high, and from three to four in circumference. By the aid of strips of bark for rope, the stems of bamboos for rafters, and the large leaf of the banana for a thatch, the Tahitians in a few minutes built us an excellent house, and with withered leaves made a soft bed.

They then proceeded to make a fire and cook our evening meal. A light was procured by rubbing a blunt-pointed stick in a groove made in another, as if with intention of deepening it, until by the friction the dust became ignited. A peculiarly white and very light wood (the Hibiscus tiliaceus) is alone used for this purpose : it is the same which serves for poles to carry any burden, and for the floating outriggers to their canoes. The fire was produced in a few seconds: but to a person who does not understand the art, it requires, as I found, the greatest exertion; but at last, to my great pride, I succeeded in igniting the dust. The Gaucho in the Pampas uses a different method: taking an elastic stick about eighteen inches long, he presses one end on his breast, and the other pointed end into a hole in a piece of wood, and then rapidly turns the curved part, like a carpenter's centre-bit. The Tahitians, having made a small fire of sticks, placed a score of stones, of about the size of cricket-balls, on the burning wood. In about teu min- 
utes the sticks were consumed and the stones hot. They had previously folded up in small parcels of leaves pieces of beef, fish, ripe and unripe bananas, and the tops of the wild arum. These green parcels were laid in a layer between two layers of the hot stones, and the whole then covered up with earth, so that no smoke or steam could escape. In about a quarter of an hour the whole was most deliciously cooked. The choice green parcels were now laid on a cloth of banana leaves, and with a cocoa-nut shell we drank the cool water of the running stream; and thus we enjoyed our rustic meal.

I could not look on the surrounding plants without admiration. On every side were forests of banana, the fruit of which, though serving for food in various ways, lay in heaps decaying on the ground. In front of us there was an extensive brake of wild sugar-cane, and the stream was shaded by the dark green knotted stem of the Ava-so famous in former days for its powerful intoxicating effects. I chewed a piece, and found that it had an acrid and unpleasant taste, which would have induced any one at once to have pronounced it poisonous. Thanks to the missionaries, this plant now thrives only in these deep ravines, innocuous to every one. Close by I saw the wild arum, the roots of which, when well baked, are good to eat, and the young leaves better than spinach. There was the wild yam, and a liliaceous plant called $\mathrm{Ti}$, which grows in abundance, and has a soft brown root, in shape and size like a huge log of wood: this served us for dessert, for it is as sweet as treacle, and with a pleasant taste. There were, moreover, several other wild fruits, and useful vegetables. The little stream, besides its cool water, produced eels and cray-fish. I did indeed admire this scene, when I compared it with an un- 
cultivated one in the temperate zones. I felt the force of the remark, that man, at least savage man, with his reasoning powers only partly developed, is the child of the tropies.

As the evening drew to a close, I strolled beneath the gloomy shade of the bananas up the course of the stream. My walk was soon brought to a close, by coming to a waterfall between two and three hundred feet high; and, again, above this there was another. I mention all these waterfalls in this one brook, to give a general idea of the inclination of the land. In the little recess where the water fell, it did not appear that a breath of wind had ever blown. The thin edges of the great leaves of the banana, damp with spray, were unbroken, instead of being, as is so generally the case, split into a thousand shreds. From our position, almost suspended on the mountain-side, there were glimpses into the depths of the neighbouring valleys; and the lofty points of the central mountains, towering up within sixty degrees of the zenith, hid half the evening sky. Thus seated, it was a sublime spectacle to watch the shades of night gradually obscuring the last and highest pinnacles.

Before we laid ourselves down to sleep, the elder Tahitian fell on his knees, and with closed eyes repeated a long prayer in his native tongue. $\mathrm{He}$ prayed as a Christian should do, with fitting reverence, and without the fear of ridicule or any ostentation of piety. A tour meals, neither of the men would taste food without saying beforehand a short grace. Those travellers who think that a Tahitian prays only when the eyes of the missionary are fixed on him, should have slept with us that night on the mountain-side. Before morning it rained very heavily, but the good thatch of banana leaves kept us dry. 
November 19th.-At daylight my friends, after their morning prayer, prepared an excellent breakfast in the same manner as in the evening. They themselves certainly partook of it largely; indeed, I never saw any men eat near so much. I suppose such enormously capacious stomachs must be the effect of a large part of their diet consisting of fruit and vegetables, which contain, in a given bulk, a comparatively smali portion of nutriment. Unwittingly, I was the means of my companions breaking, as I afterwards learned, one of their own laws and resolutions: I took with me a flask of spirits, which they could not refuse to partake of; but, as often as they drank a little, they put their fingers before their mouths, and uttered the word "Missionary." About two years ago, although the use of the ava was prevented, drunkenness from the introduction of spirits became very prevalent. The missionaries prevailed on a few good men, who saw that their country was rapidly going to ruin, to join with them in a 'Temperance Society. From good sense or shame, all the chiefs and the queen were at last persuaded to join. Immediately a law was passed that no spirits should be allowed to be introduced into the island, and that he who sold and he who bought the forbidden article should be punished by a fine. With remarkable justice, a certain period was allowed for stock in hand to be sold before the law came into effect. But when it did, a general search was made, in which even the houses of the missionaries were not exempted, and all the ava (as the natives call all ardent spirits) was poured on the ground. When one reflects on the effect of intemperance on the aborigines of the two Americas, I think it will be acknowledged that every well-wisher of Tahiti owes no common debt of gratitude to the missionaries. As long as the 
little island of St. Helena remained under the government of the East India Company, spirits, owing to the great injury they had produced, were not allowed to be imported; but wine was supplied from the Cape of Good Hope. It is rather a striking, and not very gratifying fact, that in the same year that spirits were allowed to be sold in St. Helena, their use was banished from Tahiti by the free will of the people.

After breakfast we proceeded on our journey. As my object was merely to see a little of the interior scenery, we returned by another track, which descended into the main valley lower down. For some distance we wound, by a most intricate path, along the side of the mountain which formed the valley. In the less precipitous parts we passed through extensive groves of the wild banana. The Tahitians, with their naked, tattooed bodies, their heads ornamented with flowers, and seen in the dark shade of these groves, would have formed a fine picture of man inhabiting some primeval land. In our descent we followed the line of ridges; these were exceedingly narrow, and for considerable lengths steep as a ladder, but all clothed with vegetation. The extreme care necessary in poising each step rendered the walk fatiguing. I did not cease to wonder at these ravines and precipices: when viewing the country from one of the knife-edged ridges, the point of support was so small, that the effect was nearly the same as it must be from a balloon. In this descent we had occasion to use the ropes only once, at the point where we entered the main valley. We slept under the same ledge of rock where we had dined the day before: the night was fine, but, from the depth and narrowness of the gorge, profoundly dark.

Before actually seeing this country, I found it 
difficult to understand two facts mentioned by El. lis, namely, that after the murderous battles of former times, the survivers on the conquered side retired into the mountains, where a handful of men could resist a multitude. Certainly, half a dozen men, at the spot where the Tahitian reared the old tree, could easily have repulsed thousands. Secondly, that after the introduction of Christianity there were wild men who lived in the mountains, and whose retreats were unknown to the more civilized inhabitants.

November 20th.-In the morning we started early, and reached Matavai at noon. On the road we met a large party of noble, athletic men going for wild bananas. I found that the ship, on account of the difficulty in watering, had moved to the harbour of Papawa, to which place I immediately walked. This is a very pretty spot. The cove is surrounded by reefs, and the water as smooth as in a lake. The cultivated ground, with its beautiful productions, interspersed with cottages, comes close down to the water's edge.

From the varying accounts which I had read before reaching these islands, I was very anxious to form, from my own observation, a judgment of their moral state, although such judgment would necessarily be very imperfect. First impressions at all times very much depend on one's previouslyacquired ideas. My notions were drawn from Ellis's "Polynesian Researches," an admirable and most interesting work, but naturally looking at everything under a favourable point of view ; from Beechey's Voyage, and from that of Kotzebue, which is strongly adverse to the whole missionary system. He who compares these three accounts will, I think, form a tolerably accurate conception of the present state of Tahiti. One of my impres- 
sions, which I took from the two last authorities, was decidedly incorrect, viz., that the Tahitians had become a gloomy race, and lived in fear of the missionaries. Of the latter feeling I saw no trace, unless, indeed, fear and respect be confounded under one name. Instead of discontent being a common feeling, it would be difficult in Europe to pick out of a crowd half so many merry and happy faces. The prohibition of the flute and dancing is inveighed against as wrong and foolish; the more than Presbyterian manner of keeping the Sabbath is looked at in a similar light. On these points I will not pretend to offer any opinion in opposition to men who have resided as many years as I was days on the island.

On the whole, it appears to me that the morality and religion of the inhabitants are highly creditable. There are many who attack, even more acrimoniously than Kotzebue, both the missionaries, their system, and the effects produced by it. Such reasoners never compare the present state with that of the island only twenty years ago, nor even with that of Europe at the present day; but they compare it with the high standard of Gospel perfection. They expect the missionaries to effect that which the Apostles themselves failed to do. Inasmuch as the condition of the people falls short of this high standard, blame is attached to the missionary, instead of credit for that which he has effected. They forget, or will not remember, that human sacrifices and the power of an idolatrous priesthood-a system of profligacy unparalleled in any other part of the world-infanticide, a consequence of that system-bloody wars, where the conquerors spared neither women nor children-that all these have been abolished, and that dishonesty, intemperance, and licentiousness have been greatly reduced by 
the introduction of Christianity. In a voyager to forget these things is base ingratitude, for should he chance to be at the point of shipwreck on some unknown coast, he will most devoutly pray that the lesson of the missionary may have extended thus far.

In point of morality, the virtue of the women, it has been often said, is most open to exception. But, before they are blamed too severely, it will be well distinctly to call to mind the scenes described by Captain Cook and Mr. Banks, in which the grandmothers and mothers of the present race played a part. Those who are most severe should consider how much of the morality of the women in Europe is owing to the system early impressed by mothers on their daughters, and how much in each individual case to the precepts of religion. But it is useless to argue against such reasoners : I believe that, disappointed in not finding the field of licentiousness quite so open as formerly, they will not give credit to a morality which they do not wish to practise, or to a religion which they undervalue, if not despise.

Sunday, 22d.-The harbour of Papiéte, where the queen resides, may be considered as the capital of the island: it is also the seat of government and the chief resort of shipping. Captain Fitz Roy took a party there this day to hear divine service, first in the Tahitian language, and afterwards in our own. Mr. Pritchard, the leading missionary in the island, performed the service. The chapel consisted of a large, airy framew ork of wood, and it was filled to excess by tidy, clean people, of all ages and both sexes. I was rather disappointed in the apparent degree of attention, but I believe my expectations were raised too high. At all events, the appearance was quite equal to that in a counII. 
try church in England. 'The singing of the hymns was decidedly very pleasing; but the language from the pulpit, although fluently delivered, did not sound well: a constant repetition of words, like "tata ta, mata mai," rendered it monotonous. After English service, a party returned on foot to Matavai. It was a pleasant walk, sometimes along the sea-beach, and sometimes under the shade of the many beautiful trees.

About two year's ago, a small vessel under English colours was plundered by some of the inhabitants of the Low Islands, which were then under the dominion of the Queen of Tahiti. It was believed that the perpetrators were instigated to this act by some indiscreet laws issued by her majesty. The British government demanded compensation, which was acceded to, and a sum of nearly three thousand dollars was agreed to be paid on the first of last September. The Commodore at Lima ordered Captain Fitz Roy to inquire concerning this debt, and to demand satisfaction if it were not paid. Captain Fitz Roy accordingly requested an interview with the Queen Pomarre, since famous from the ill treatment she has received from the French, and a parliament was held to consider the question, at which all the principal chiefs of the island and the queen were assembled. I will not attempt to describe what took place, after the interesting account given by Captain Fitz Roy. The money, it appeared, had not been paid; perhaps the alleged reasons were rather equivocal; but otherwise, I cannot sufficiently express our general surprise at the extreme good sense, the reasoning powers, moderation, candour, and prompt resolution, which were displayed on all sides. I believe we all left the meeting with a very different opinion of the Tahitians from what we entertained when we entered. 
The chiefs and people resolved to subscribe and complete the sum which was wanting: Captain Fitz Roy urged that it was hard that their private property should be sacrificed for the crimes of distant islanders. 'They replied that they were grateful for his consideration, but that Pomarre was their queen, and that they were determined to help her in this her difficulty. This resolution and its prompt execution, for a book was opened early the next morning, made a perfect conclusion to this very remarkable scene of loyalty and good feeling.

After the main discussion was ended, several of the chiefs took the opportunity of asking Captain Fitz Roy many intelligent questions on international customs and laws relating to the treatment of ships and foreigners. On some points, as soon as the docision was made, the law was issued verbally on the spot. This 'Tahitian parliament lasted for several hours, and when it was over Captain Fitz Roy invited Queen Pomarre to pay the Beagle a visit.

November 25th. - In the evening four boats were sent for her majesty; the ship was dressed with flags, and the yards manned on her coming on board. She was accompanied by most of the chiefs. The behaviour of all was very proper: they begged for nothing, and seemed much pleased with Captain Fitz Roy's presents. The queen is a large, awkward woman, without any beauty, grace, or dignity. She has only one royal attribute, a perfect immoveability of expression under all circumstances, and that rather a sullen one. The rockets were most admired; and a deep "Oh!" could be heard from the shore, all round the dark bay, after each explosion. 'The sailors' songs were also much admired, and the queen said she thought 
that one of the most boisterous ones eertainly could not be a hymn! The royal party did not return on shore till past midnight.

26th.-In the evening, with a gentle land-breeze, a course was steered for New Zealand; and as the sun set, we had a farewell view of the mountains of Tahiti, the island to which every voyager has offered up his tribute of admiration.

December 19th.- In the evening we saw in the distance New Zealand. We may now consider that we have nearly crossed the Pacific. It is necessary to sail over this great ocean to comprehend its immensity. Moving quickly onwards for weeks together, we meet with nothing but the same blue, profoundly deep ocean. Even within the archi. pelagoes, the islands are mere specks, and far distant one from the other. Accustomed to look at maps drawn on a small scale, where dots, shading, and names are crowded together, we do not rightly judge how infinitely small the proportion of dry land is to the water of this vast expanse. The meridian of the Antipodes has likewise been passed; and now every league, it made us happy to think, was one league nearer to England. These Antipodes call to one's mind old recollections of childish doubt and wonder. Only the other day I looked forward to this airy barrier as a definite point in our voyage homeward; but now I find that it and all such resting-places for the imagination are like shadows, which a man moving onward cannot catch. A gale of wind, lasting for some days, has lately given us full leisure to measure the future stages in our long homeward voyage, and to wish most earnestly for its termination.

December 21st.-Early in the morning we entered the Bay of Islands, and being becalmed for some hours near the mouth, we did not reach the 
anchorage till the middle of the day. The country is hilly, with a smooth outline, and is deeply intersected by numerous arms of the sea extending from the bay. The surface appears from a distance as if clothed with coarse pasture, but this, in truth, is nothing but fern. On the more distant hills, as well as in parts of the valleys, there is a good deal of woodland. The general tint of the landscape is not a bright green; and it resembles the country a short distance to the south of Concepcion in Chile. In several parts of the bay, little villages of square, tidy-looking houses are scattered close down to the water's edge. Three whaling-ships were lying at anchor, and a canoe every now and then crossed from shore to shore; with these exceptions, an air of extreme quietness reigned over the whole district. Only a single canoe came alongside. This, and the aspect of the whole scene, afforded a remarkable, though not very pleasing contrast with our joyful and boisterous welcome at Tahití.

In the afternoon we went on shore to one of the larger groups of houses, which yet hardly deserves the title of a village. Its name is Pahia : it is the residence of the missionaries; and there are no native residents except servants and labourers. In the vicinity of the Bay of Islands, the number of Englishmen, including their families, amounts to between two and three hundred. All the cottages, many of which are white-washed and look very neat, are the property of the English. The hovels of the natives are so diminutive and paltry that they can scarcely be perceived from a distance. At Pahia, it was quite pleasing to behold the English flowers in the gardens before the houses; there were roses of several kinds, honeysuckle, jasmine, stocks, and whole hedges of sweetbrier. 
December 22d.-In the morning I went out walking, but I soon found that the country was very impracticasle. All the hills are thickly covered with tall fern, together with a low bush which grows like a cypress; and very little ground has been cleared or cultivated. I then tried the sea-beach; but, proceeding towards either hand, my walk was soon stopped by salt-water creeks and deep brooks. The communication between the inhabitants of the different parts of the bay is (as in Chiloe) almost entirely kept up by boats. I was surprised to find that almost every hill which I ascended had been at some former time more or less fortified. The summits were cut into steps or successive terraces, and frequently they had been protected by deep trenches. I afterwards observed that the principal hills inland in like manner showed an artificial outline. These are the Pas, so frequently mentioned by Captain Cook under the name of "hippah;" the difference of sound being owing to the prefixed article.

That the Pas had formerly been much used, was evident from the piles of shells, and the pits in which, as I was informed, sweet potatoes used to be kept as a reserve. As there was no water on these hills, the defenders could never have anticipated a long siege, but only a hurried attack for plunder, against which the successive terraces would have afforded good protection. The general introduction of fire-arms has changed the whole system of warfare; and an exposed situation on the top of a hill is now worse than useless. The Pas in consequence are, at the present day, always built on a level piece of ground. They consist of a double stockade of thick and tall posts, placed in a zigzag line, so that every part can be flanked. Within the stockade a mound of earth is thrown 
up, behind which the defenders can rest in safety, or use their fire-arms over it. On the level of the ground little archways sometimes pass through this breastwork, by which means the defenders can crawl out to the stockade to reconnoitre their enemies. The Rev. W. Williams, who gave me this account, added, that in one Pas he had noticed spurs or buttresses projecting on the inner and protected side of the mound of earth. On asking the chief the use of them, he replied, that if two or three of his men were shot, their neighbours would not see the bodies, and so be discouraged.

These Pas are considered by the New Zealanders as very perfect means of defence: for the attacking force is never so well disciplined as to rush in a body to the stockade, cut it down, and effect their entry. When a tribe goes to war, the chief cannot order one party to go here and another there, but every man fights in a manner which best pleases himself; and to each separate individual to approach a stockade defended by fire-arms must appear certain death. I should think a more warlike race of inhabitants could not be found in any part of the world than the New Zealanders. Their conduct on first seeing a ship, as described by Captain Cook, strongly illustrates this: the act of throwing volleys of stones at so great and novel an object, and their defiance of "Come on shore and we will kill and eat you all," shows uncommon boldness. This warlike spirit is evident in many of their customs, and even in their smallest actions. If a New Zealander is struck, although but in joke, the blow must be returned; and of this I saw an instance with one of our officers.

At the present day, from the progress of civilization, there is much less warfare, except among some of the southern trihes. I heard a character- 
istic anecdote of what took place some time ago in the south. A missionary found a chief and his tribe in preparation for war-their muskets clean and bright, and their ammunition ready. He reasoned long on the inutility of the war, and the little provocation which had been given for it. The chief was much shaken in his resolution, and seemed in doubt; but at length it occurred to him that a barrel of his gumpowder was in a bad state, and that it would not keep much longer. This was brought forward as an unanswerable argument for the necessity of immediately declaring war: the idea of allowing so much good gunpowder to spoil was not to be thought of, and this settled the point. I was told by the missionaries that in the life of Shongi, the chief who visited England, the love of war was the one and lasting spring of every action. The tribe in which he was a principal chief had at one time been much oppressed by another tribe from the Thames River. A solemn oath was taken by the men, that when their boys should grow up, and they should be powerful enough, they would never forget or forgive these injuries. To fulfil this oath appears to have been Shongi's chief motive for going to England, and when there it was his sole object. Presents were valued only as they could be converted into arms; of the arts, those alone interested him which were connected with the manufacture of arms. When at Sydney, Shongi, by a strange coincidence, met the hostile chief of the Thames River at the house of Mr. Marsden : their conduct was civil to each other; but Shongi told him that, when again in New Zealand, he would never cease to carry war into his country. The challenge was accepted, and Shongi, on his return, fulfilled the threat to the utmost letter. The tribe on the Thames River 
was utterly overthrown, and the chief to whom the challenge had been given was himself killed. Shongi, although harbouring such deep feelings of hatred and revenge, is described as having been a good-natured person.

In the evening I went with Captain Fitz Roy and Mr. Baker, one of the missionaries, to pay a visit to Kororadika : we wandered about the village, and saw and conversed with many of the people, both men, women, and children. Looking at the New Zealander, one naturally compares him with the Tahitian, both belonging to the same family of mankind. The comparison, however, tells heavily against the New Zealander. He may, perhaps, be superior in energy, but in every other respect his character is of a much lower order. One glance at their respective expressions brings conviction to the mind that one is a savage, the other a civilized man. It would be vain to seek in the whole of New Zealand a person with the face and mien of the old Tahitian chief Utamme. No doubt the extraordinary manner in which tattooing is here practised gives a disagreeable expression to their countenances. The complicated but symmetrical figures covering the whole face puzzle and mislead an unaccustomed eye : it is, moreover, probable that the deep incisions, by destroying the play of the superficial muscles, give an air of rigid inflexibility; but, besides this, there is a twinkling in the eye which cannot indicate anything but cunning and ferocity. Their figures are tall and bulky, but not comparable in elegance with those of the working-classes in Tahiti.

Both their persons and houses are filthily dirty and offensive: the idea of washing either their bodies or their clothes never seems to enter their heads. I saw a chief, who was wearing a shirt 
black and matted with filth, and when asked how it eame to be so dirty, he replied, with surprise, "Do not you see it is an old one?" Some of the men have shirts; but the common dress is one or two large blankets, generally black with dirt, which are thrown over their shoulders in a very ineonvenient and awkward fashion. A few of the principal chiefs have deeent suits of English clothes, but these are only worn on great oceasions.

December 23d.-At a place called Waimate, about fifteen miles from the Bay of Islands, and midway between the eastern and western eoasts, the missionaries have purchased some land for agricultural purposes. I had been introduced to the Rev. W. Williams, who, upon my expressing a wish, invited me to pay him a visit there. Mr. Bushby, the British resident, offered to take me in his boat by a ereek, where I should see a pretty waterfall, and by which means my walk would be shortened. He likewise procured for me a guide. Upon asking a neighbouring chicf to reeommend a man, the chief himself offered to go; but his ignorance of the value of money was so eomplete, that at first he asked how many pounds I would give him, but afterwards was well contented with two dollars. When I showed the chicf a very small bundle which I wanted earried, it became absolutely neeessary for him to take a slave. These feelings of pride are beginning to wear away; but formerly a leading man would sooner have died than undergone the indignity of carrying the smallest burden. My companion was a light, active man, dressed in a dirty blanket, and with his face completely tattooed. He had formerly been a great warrior. $\mathrm{He}$ appeared to be on very cordial terms with Mr. Bushby, but at various times they had quarrelled violently. Mr. Bushly remarked that a little quiet 
irony would frequently silence any one of these natives in their most blustering moments. This chief has come and harangued Mr. Bushby in a hectoring manner, saying, "A great chief, a great man, a firiend of mine, has come to pay me a visit-you must give him something good to eat, some fine presents," \&c. Mr. Bushby has allowed him to finish his discourse, and then has quietly replied by some such answer as, "What else shall your slave do for you ?" The man would then instantly, with a very comical expression, cease his braggadocio.

Some time ago, Mr. Bushby suffered a far more serious attack. A chief and a party of men tried to break into his house in the middle of the night, and not finding this so easy, commenced a brisk firing with their muskets. Mr. Bushby was slightly wounded, but the party was at length driven away. Shortly afterwards it was discovered who was the aggressor, and a general meeting of the chiefs was convened to consider the case. It was considered by the New Zealanders as very atrocious, inasmuch as it was a night attack, and that Mrs. Busbby was lying ill in the house: this latter circumstance, much to their honour, being considered in all cases as a protection. The chiefs agreed to confiscate the land of the aggressor to the King of England. The whole proceeding, however, in thus trying and punishing a chief, was entirely without precedent. 'The aggressor, moreover, lost caste in the estimation of his equals; and this was considered by the British as of more consequence than the confiscation of his land.

As the boat was shoving off, a second chief stepped into her, who only wanted the amusement of the passage up and down the creek. I never saw a more horrid and ferocious expression than this man had. It immediately struck me I had somo. 
where seen his likeness: it will be found in Retzch's outlines to Schiller's ballad of Fridolin, where two men are pushing Robert into the burning iron furnace. It is the man who has his arm on Robert's breast. Physiognomy here spoke the truth; this chief had been a notorious murderer, and was an arrant cowart to boot. At the point where the boat landed, Mr. Busliby accompanied me a few hundred yards on the road: I could not help admiring the cool impudence of the hoary old villain, whom we left lying in the boat, when he shouted to Mr. Bushby, "Do not you stay long; I shall be tired of waiting here."

We now commenced our walk. The road lay along a well-beaten path, bordered on each side by the tall fern which covers the whole country. After travelling some miles, we came to a little country village, where a few hovels were collected together and some patches of ground cultivated with potatoes. The introduction of the potato has been the most essential benefit to the island: it is now much more used than any native vegetable. New Zealand is favoured by one great natural advantage, namely, that the inhabitants can never perish from famine. The whole country abounds with fern; and the roots of this plant, if not very palatable, yet contain much nutriment. A native can always subsist on these, and on the shell-fish, which are abundant on all parts of the sea-coast. The villages are chiefly conspicuous by the platforms, which are raised on four posts ten or twelve feet above the ground, and on which the produce of the fields is kept secure from all accidents.

On coming near one of the huts, I was much amused by seeing in due form the ceremony of rubbing, or, as it ought to be called, pressing noses. The women, on our first approach, began 
uttering something in a most dolorous voice; they then squatted themselves down and held up their faces; my companion standing over them, one after another, placed the bridge of his nose at right angles to theirs, and commenced pressing. This lasted rather longer than a cordial shake of the hand with us; and as we vary the force of the grasp of the hand in shaking, so do they in pressing. During the process they uttered comfortable little grunts, very much in the same manner as two pigs do when rubbing against each other. I noticed that the slave would press noses with any one he met, indifferently either before or after his master the chief. Although among these savages the chief has absolute power of life and death over his slave, yet there is an entire absence of ceremony between them. Mr. Burchell has remarked the same thing in Southern Africa with the rude Bachapins. Where civilization has arrived at a certain point, complex formalities soon arise between the different grades of society: thus, at Tahiti, all were formally obliged to uncover themselves as low as the waist in presence of the king.

The ceremony of pressing noses having been duly completed with all present, we seated ourselves in a circle in front of one of the hovels, and rested there half an hour. All the hovels have nearly the same form and dimensions, and all agree in being filthily dirty. They resemble a cow-shed with one end open, but having a partition a little way within, with a square hole in it, making a small, gloomy chamber. In this the inhabitants keep all their property, and when the weather is cold they sleep there. They eat, however, and pass their time in the open part in front. My guides having finished their pipes, we continued our walk. The path led through the same II. $\rightarrow \mathrm{S}$ 
undulating country, the whole uniformly clothed as before with fern. On our right hand we had a serpentine river, the banks of which were fringed with trees, and here and there on the hill sides there was a clump of wood. The whole scene, in spite of its green colour, had rather a desolate aspect. The sight of so much fern impresses the mind with an idea of sterility: this, however, is not correct; for, wherever the fern grows thick and breast-high, the land, by tillage, becomes productive. Some of the residents think that all this extensive open country originally was covered with forests, and that it has been cleared by fire. It is said that, by digging in the barest spots, lumps of the kind of resin which flows from the kauri pine are frequently found. The natives had an evident motive in clearing the country; for the fern, formerly a staple article of food, flourishes only in the open, cleared tracks. The almost entire absence of associated grasses, which forms so remarkable a feature in the vegetation of this island, may perhaps be accounted for by the land having been aboriginally covered with forest-trees.

The soil is volcanic: in several parts we passed over slaggy lavas, and craters could clearly be distinguished on several of the neighbouring hills. Although the scenery is nowhere beautiful, and only occasionally pretty, I enjoyed my walk. I should have enjoyed it more if my companion the chief had not possessed extraordinary conversational powers. I knew only three words, " good," "bad," and "yes," and with these I answered all his remarks, without, of course, having understood one word he said. This, however, was quite sufficient: I was a good listener, an agreeable person, and he never ceased talking to me.

At length we reached Waimate. After having 
passed over so many miles of an uninhabited, useless country, the sudden appearance of an English farm-house, and its well-dressed fields, placed there as if by an enchanter's wand, was exceedingly pleasant. Mr. Williams not being at home, I received in Mr. Davies's house a cordial welcome. After drirking tea with his family party, we took a stroll about the farm. At Waimate there are three large houses, where the missionary gentlemen, Messrs. Williams, Davies, and Clarke, reside, and near them are the huts of the native labourers. On an adjoining slope, fine crops of barley and wheat were standing in full ear, and in another part fields of potatoes and clover; but I cannot attempt to describe all I saw. There were large gardens, with every fruit and vegetable which England produces, and many belonging to a warmer clime. I may instance asparagus, kidney-beans, cucumbers, rhubarb, apples, pears, figs, peaches, apricots, grapes, olives, gooseberries, currants, hops, gorse for fences, and English oaks; also many kinds of flowers. Around the farm-yard there were stables, a threshing-barn with its winnowing machine, a blacksmith's forge, and on the ground ploughshares and other tools. In the middle was that happy mixture of pigs and poultry, lying comfortably together, as in every English farm-yard. At the distance of a few hundred yards, where the water of a little rill had been dammed up into a pool, there was a large and substantial water-mill.

All this is very surprising, when it is considered that five years ago nothing but the fern flourished here. Noreover, native workmanship, taught by the missionaries, has effected this change; the lesson of the missionary is the enchanter's wand. The house had been built, the windows framed, 
the fields ploughed, and even the trees grafted, by the New Zealander. At the mill a New Zealander was seen powdered white with flour, like his brother miller in England. When I looked at this whole scene I thought it admirable. It was not merely that England was brought vividly before my mind; yet, as the evening drew to a close, the domestic sounds, the fields of corn, the distant undulating country with its trees, might well have been mistaken for our father-land. Nor was it the triumphant feeling at seeing what Englishmen could effect, but rather the high hopes thus inspired for the future progress of this fine island.

Several young men, redeemed by the missionaries from slavery, were employed on the farm. They were dressed in a shirt, jacket, and trousers, and had a respectable appearance. Judging from one trifling anecdote, I should think they must be honest. When walking in the fields, a young labourer came up to Mr. Davies and gave him a knife and gimlet, saying that he had found them on the road, and did not know to whom they belonged! These young men and boys appeared very merry and good-humoured. In the evening I saw a party of them at cricket: when I thought of the austerity of which the missionaries have been accused, I was amused by observing one of their own sons taking an active part in the game. A more decided and pleasing change was manifested in the young women, who acted as servants within the houses. Their clean, tidy, and healthy appearance, like that of dairy-maids in England, formed a wonderful contrast with the women of the filthy hovels in Kororadika. The wives of the missionaries tried to persuade them not to be tattooed; but a famous operator having arrived from the south, they said, "We really must just have a 
few lines on our lips, else when we grow old our lips will shrivel, and we shall be so very ugly." There is not nearly so much tattooing as formerly ; but as it is a badge of distinction between the chief and the slave, it will probably long be practised. So soon does any train of ideas become habitual, that the missionaries told me that even in their eyes a plain face looked mean, and not like that of a New Zealand gentleman.

Late in the evening I went to Mr. Williams's house, where I passed the night. I found there a large party of children, collected together for Christmas-day, and all sitting round a table at tea. I never saw a nicer or more merry group; and to think that this was in the centre of the land of cannibalism, murder, and all atrocious crimes! The cordiality and happiness so plainly pictured in the faces of the little circle, appeared equally felt by the older persons of the mission.

December 24th.-In the morning prayers were read in the native tongue to the whole family. After breakfast I rambled about the gardens and farm. This was a market-day, when the natives of the surrounding hamlets bring their potatoes, Indian corn, or pigs, to exchange for blankets, tobacco, and sometimes, through the persuasions of the missionaries, for soap. Mr. Davies's eldest son, who manages a farm of his own, is the man of business in the market. The children of the missionaries, who came while young to the island, understand the language better than their parents, and can get anything more readily done by the natives.

A little before noon, Messrs. Williams and Davies walked with me to part of a neighbouring forest to show me the famous kauri pine. I measured one of these noble trees, and found it thirtyII. 
one feet in circumference above the roots. There was another close by, which I did not see, thirtythree feet; and I heard of one no less than forty feet. These trees are remarkable for their smooth, cylindrical bolls, which run up to a height of sixty, and even ninety feet, with a nearly equal diameter, and without a single branch. The crown of branches at the summit is out of all proportion small to the trunk, and the leaves are likewise small compared with the branches. The forest was here almost composed of the kauri; and the largest trees, from the parallelism of their sides, stood up like gigantic columns of wood. The timber of the kauri is the most valuable production of the islant; moreover, a quantity of resin oozes from the bark, which is sold at a pemny a pound to the Americans, but its use was then unknown. Some of the New Zealand forests must be impenetrable to an extraordinary degree. Mr. Matthews informed me that one forest, only thirty-four miles in width, and separating two inhabited districts, had only lately, for the first time, been crossed. $\mathrm{He}$ and another missionary, each with a party of about fifty men, undertook to open a road; but it cost them more than a fortnight's labour! In the woods I saw very few birds. With regard to animals, it is a most remarkable fact, that so large an island, extending over more than 700 miles in latitude, and in many parts ninety broad, with varied stations, a fine climate, and land of all heights, from 14,000 feet downwards, with the exception of a small rat, did not possess one indigenous animal. The several species of that gigantic genus of birds, the Deinornis, seem here to have replaced mammiferous quadrupeds, in the same manner as the reptiles still do at the Galapagns Archipelago. It is said that the common Norway rat, in the short space of two years, 
annihilated, in this northern end of the island, the New Zealand species. In many places I noticed several sorts of weeds, which, like the rats, I was forced to own as countrymen. A leek has overrun whole districts, and will prove very troublesome, but it was imported as a favour by a French vessel. The common dock is also widely disseminated, and will, I fear, forever remain a proof of the rascality of an Englishman, who sold the seeds for those of the tobacco plant.

On returning from our pleasant walk to the house, I dined with Mr. Williams, and then, a horse being lent me, I returned to the Bay of Islands. I took leave of the missionaries with thankfulness for their kind welcome, and with feelings of high respect for their gentlemanlike, useful, and upright characters. I think it would be difficult to find a body of men better adapted for the high office which they fulfil.

Christmas Day.-In a few more days the fourth year of our absence from England will be completed. Our first Christmas day was spent at Plymouth; the second at St. Martin's Cove, near Cape Horn; the third at Port Desire, in Patagonia; the fourth at anchor in a wild harbour in the peninsula of Tres Montes: the fifth here; and the next, I trust in Providence, will be in England. We attended divine worship in the chapel of Pahia, part of the service being read in English and part in the native language. Whilst at New Zealand we did not hear of any recent acts of cannibalism, but Mr. Stokes found burned human bones strewed round a fire-place on a small island near the anchorage; but these remains of a comfortable banquet might have been lying there for several years. It is probable that the moral state of the people will rapidly improve. Mr. Bushby mentioned one pleasing an- 
ecdute as a proof of the sincerity of some, at least, of those who profess Christianity. One of his young men left him who had been accustomed to read prayers to the rest of the servants. Some weeks afterwards, happening to pass late in the evening by an outhouse, he saw and heard one of his men reading the Bible with difficulty, by the light of the fire, to the others. After this, the party knelt and prayed : in their prayers they mentioned Mr. Bushby and his family, and the missionaries, each separately in his respective district.

December 26th.-Nr. Bushby offered to take Mr. Sulivan and myself in his boat some miles up the river to Cawa-Cawa, and proposed afterwards to walk on to the village of $\mathrm{W}$ aiomio, where there are some curious rocks. Following one of the arms of the bay, we enjoyed a pleasant row, and passed through pretty scenery until we came to a village, beyond which the boat could not pass. From this place a chief and a party of men volunteered to walk with us to Waiomio, a distance of four miles. The chief was at this time rather notorious from having lately hung one of his wives and a slave for adultery. When one of the missionaries remonstrated with him, he seemed surprised, and said he thought he was exactly following the English method. Old Shongi, who happened to be in England during the Qucen's trial, expressed great disapprobation at the whole proceeding : he said he had five wives, and he would rather cut off all their heads than be so much troubled about one. Leaving this village, we crossed over to another, seated on a hill side at a little distance. The daughter of a chief, who was still a heathen, had died there five days before. The hovel in which she had expired had been burned to the ground; her body, being enclosed between two small canoes, was placed up- 
right on the ground, and protected by an enclosure bearing wooden images of their gods, and the whole was painted bright red, so as to be conspicuous from afar. Her gown was fastened to the coffir, and her hair being cut off, was cast at its foot. The relatives of the family had torn the flesh of their arms, bodies, and faces, so that they were covered with clotted blood, and the old women looked most filthy, disgusting objects. On the following day some of the officers visited this place, and found the women still howling and cutting themselves.

We continued our walk, and soon reached Waiomio. Here there are some singular masses of limestone, resembling ruined castles. These rocks have long served for burial-places, and, in consequence, are held too sacred to be approached. One of the young men, however, cried out, "Let us all be brave," and ran on ahead; but when within a hundred yards, the whole party thought better of it, and stopped short. With perfect indifference, however, they allowed us to examine the whole place. At this village we rested some hours, during which time there was a long discussion with Mr. Bushby concerning the right of sale of certain lands. One old man, who appeared a perfect genealogist, illustrated the successive possessors by bits of stick driven into the ground. Before leaving the houses, a little basketful of roasted sweet potatoes was given to each of our party, and we all, according to the custom, carried them away to eat on the road. I noticed that among the women employed in cooking there was a man slave: it must be a humiliating thing for a man in this warlike country to be employed in doing that which is considered as the lowest woman's work. Slaves are not allowed to go to war; but this, perhaps, can hardly be considered as a hardship. I heard of 
one poor wretch, who, during hostilities, ran away to the opposite party; being met by two men, he was immediately seized, but as they could not agree to whom he should belong, each stood over him with a stone hatchet, and seemed determined that the other, at least, should not take him away alive. The poor man, almost dead with fright, was only saved by the address of a chief's wife. We afterwards enjoyed a pleasant walk back to the boat, but did not reach the ship till late in the evening.

December $30 t h$. - In the afternoon we stood out of the Bay of Islands, on our course to Sydney. I believe we were all glad to leave New Zealand. It is not a pleasant place. Amongst the natives there is absent that charming simplicity which is found at Tahiti, and the greater part of the English are the very refuse of society. Neither is the comntry itself attractive. I look back but to one bright spot, and that is IVaimate, with its Christian inhabitants.

\section{CHAPTER VII.}

Sydney-Excursion to Bathurst-Aspect of the Woods-Party of

Natives-Gradual Extinction of the Aborigines-Infection generated by associated Men in Health-Blue Mountains-View of the grand gulf-like Valleys-Their Origin and FormationBathurst, general Civility of the lower Orders-State of Society-Van Diemen's Land-Hobart Town-Aborigines all banished-Mount Wellington-King George's Sound-Cheerless Aspect of the Country-Bald Head, calcareous Casts of Branches of Trees-Party of Natives-Leave Australia.

AUSTRALIA.

January 12th, 1836.-EARLY in the morning a light air carried us towards the entrance of Port Jackson. Instead of beholding a verdant country, interspersed with fine houses, a straight line of 
yellowish cliff brought to our minds the coast of Patagonia. A solitary lighthouse, built of white stone, alone told us that we were near a great and populous city. Having entered the harbour, it appears fine and spacious, with cliff-formed shores of horizontally stratified sandstone. The nearly level country is covered with thin, scrubby trees, bespeaking the curse of sterility. Proceeding further inland, the country improves: beautiful villas and nice cottages are here and there scattered along the beach. In the distance, stone houses, two and three stories high, and windmills standing on the edge of a bank, pointed out to us the neighbourhood of the capital of Australia.

At last we anchored within Sydney Cove. We found the little basin occupied by many large ships, and surrounded by warehouses. In the evening I walked through the town, and returned full of admiration at the whole scene. It is a most magnificent testimony to the power of the British nation. Here, in a less promising country, scores of years have done many times more than an equal number of centuries have effected in South America. My first feeling was to congratulate myself that I was born an Englishman. Upon seeing more of the town afterwards, perhaps my admiration fell a little; but yet it is a fine town. The streets are regular, broad, clean, and kept in excellent order; the houses are of a good size, and the shops well furnished. It may be faithfully compared to the large suburbs which stretch out from London and a few other great towns in England; but not even near London or Birmingham is there an appearance of such rapid growth. The number of large houses and other buildings just finished was truly surprising; nevertheless, every one complained of the high rents and difficulty in procuring a house. 
Coming from South America, where in the towns every man of property is known, no one thing surprised me more than not being able to ascertain at once to whom this or that carriage belonged.

I hired a man and two horses to take me to Bathurst, a village about one hundred and twenty miles in the interior, and the centre of a great pastoral district. By this means I hoped to gain a general idea of the appearance of the country. On the morning of the 16 th (January) I set out on my excursion. The first stage took us to Paramatta, a small country town, next to Sydney in importance. The roads were excellent, and made upon the MacAdam principle, whinstone having been brought for the purpose from the distance of several miles. In all respects there was a close resemblance to England: perhaps the alehouses here were more numerous. The iron gangs, or parties of convicts who have committed here some offence, appeared the least like England: they were working in chains, under the charge of sentries with loaded arms. The power which the government possesses, by means of forced labour, of at once opening good roads throughout the country, has becn, I believe, one main cause of the early prosperity of this colony. I slept at night at a very comfortable inn at Emu ferry, thirty-five miles from Sydney, and near the ascent of the Blue Mountains. This line of road is the most frequented, and has been the longest inhabited of any in the colony. The whole land is enclosed with high railings, for the farmers have not succeeded in rearing hedges. There are many substantial houses and good cottages scattered about; but, although considerable pieces of land are under cultivation, the greater part yet remains as when first discovered.

The extreme uniformity of the vegetation is the 
most remarkable feature in the landscape of the greater part of New South Wales. Everywhere we have an open woodland, the ground being partially covered with a very thin pasture, with little appearance of verdure. The trees nearly all belong to one family, and mostly have their leaves placed in a vertical, instead of, as in Europe, in a nearly horizontal position: the foliage is scanty, and of a peculiar pale green tint, without any gloss. Hence the woods appear light and shadowless : this, although a loss of comfort to the traveller under the scorching rays of summer, is of importance to the farmer, as it allows grass to grow where it otherwise would not. The leaves are not shed periodically : this character appears common to the entire southern hemisphere, namely, South America, Australia, and the Cape of Good Hope. The inhabitants of this hemisphere and of the intertropical regions thus lose, perhaps, one of the most glorious, though, to our eyes, common spectacles in the world - the first bursting into full foliage of the leafless tree. They may, however, say that we pay dearly for this by having the land covered with mere naked skeletons for so many months. This is too true; but our senses thus acquire a keen relish for the exquisite green of the spring, which the eyes of those living within the tropics, sated during the long year with the gorgeous productions of those glowing climates, can never experience. The greater number of the trees, with the exception of some of the Blue-gums, do not attain a large size, but they grow tall and tolerably straight, and stand well apart. The bark of some of the Eucalypti falls annually, or hangs dead in long shreds, which swing about with the wind, and give to the woods a desolate and untidy appearance. I cannot imagine a more complete II.-T 
contrast in every respect than between the forests of Valdivia or Chiloe and the woods of Australia.

At sunset, a party of a score of the black aborigines passed by, each carrying, in their accustomed manner, a bundle of spears and other weapons. By giving a leading young man a shilling they were easily detained, and threw their spears for my amusement. They were all partly clothed, and several could speak a little English: their countenances were good-humoured and pleasant, and they appeared far from being such utterly degraded beings as they have usually been represented. In their own arts they are admirable. A cap being fixed at thirty yards' distance, they transfixed it with a spear, delivered by the throwing-stick with the rapidity of an arrow from the bow of a practised archer. In tracking animals or men they show most wonderful sagacity; and I heard of several of their remarks which manifested considerable acuteness. They will not, however, cultivate the ground, or build houses and remain stationary, or even take the trouble of tending a flock of sheep when given to them. On the whole, they appear to me to stand some few degrees higher in the scale of civilization than the Fuegians.

It is very curious thus to see, in the midst of a civilized people, a set of harmless savages wandering about without knowing where they shall sleep at night, and gaining their livelihood by hunting in the woods. As the white man has travelled onwards, he has spread over the country belonging to several tribes. These, although thus enclosed by one common people, keep up their ancient distinctions, and sometimes go to war with each other. In an engagement which took place lately, the two parties most singularly chose the centre of the village of Bathurst for the field of battle. This was 
of service to the defeated side, for the runaway warriors took refuge in the barracks.

The number of aborigines is rapidly decreasing. In my whole ride, with the exception of some boys brought up by Englishmen, I saw only one other party. This decrease, no doubt, must be partly owing to the introduction of spirits, to European diseases (even the milder ones of which, such as the measles, ${ }^{*}$ prove very destructive), and to the gradual extinction of the wild animals. It is said that numbers of their children invariably perish in very early infancy from the effects of their wandering life; and as the difficulty of procuring food increases, so must their wandering habits increase; and hence the population, without any apparent deaths from famine, is repressed in a manner extremely sudden compared to what happens in civilized countries, where the father, though in adding to his labour he may injure himself, does not destroy his offspring.

Besides these several evident causes of destruction, there appears to be some more mysterious agency generally at work. Wherever the European has trod, death seems to pursue the aboriginal. We may look to the wide extent of the Americas, Polynesia, the Cape of Good Hope, and Australia, and we find the same result. Nor is it the white man alone that thus acts the destroyer; the Polynesian of Malay extraction has, in parts of the East Indian Archipelago, thus driven before him the dark-coloured native. The varieties of

* It is remarkable how the same disease is modified in different climates. At the little island of St. Helena, the introduction of scarlet fever is dreaded as a plague. In some countries, foreigners and natives are as differently affected by certain contagious disorders as if they had been different animals; of which fact some instances have occurred in Chile, and, according to Humboldt, in Mexico. (Polit. Essay, New Spain, vol. iv.) 
man seern to act on each other in the same way as different species of animals-the stronger always extirpating the weaker. It was melancholy at New Zealand to hear the fine, energetic natives saying that they knew the land was doomed to pass from their children. Every one has heard of the inexplicable reduction of the population in the beautiful and healthy island of Tahiti since the date of Captain Cook's voyages, although in that case we might have expected that it would have been increased; for infanticide, which formerly prevailed to so extraordinary a degree, has ceased, profligacy has greatly diminished, and the murderous wars become less frequent.

The Rev. J. Williams, in his interesting work, * says, that the first intercourse between natives and Europeans " is invariably attended with the introduction of fever, dysentery, or some other disease, which carries off numbers of the people." Again he affirms, "It is certainly a fact, which cannot be controverted, that most of the diseases which have raged in the islands during my residence there have been introduced by ships; $t$ and what renders

* Narrative of Missionary Enterprise, p. 282.

$\dagger$ Captain Beechey (chap. iv., vol. i.) states that the inhabitants of Pitcairn Island are firmly convinced that after the arrival of every ship they suffer cutaneous and other disorders. Captain Beechey attributes this to the change of diet during the time of the visit. Dr. Macculloch (Western Isles, vol. ii., p. 32) says, "It is asserted, that on the arrival of a stranger (at St. Kilda) all the inhabitants, in the common phraseology, catch a cold." Dr. Macculloch considers the whole case, although often previously affirmed, as ludicrous. He adds, however, that "the question was put by us to the inhabitants, who unanimously agreed in the story." In Vancouver's Voyage, there is a somewhat similar statement with respect to Otaheite. Dr. Dieffenbach, in a note to his translation of this Journal, states that the same fact is universally believed by the inhabitants of the Chatham Islands, and in parts of New Zealand. It is impossible that such a belief shonld have become universal in the northern hemisphere, at the Antipodes, and in the Pacific, without some good foundation. Humboldt (Polit. Essay on King. of New Spain, vol. iv.) says, 
this fact remarkable is, that there might be no appearance of disease among the crew of the ship which conveyed this destructive importation." This statement is not quite so extraordinary as it at first appears; for several cases are on record of the most malignant fevers having broken out, although the parties themselves, who were the cause, were not affected. In the early part of the reign of George III., a prisoner who had been confined in a dungeon was taken in a coach, with four constables, before a magistrate; and, although the man himself was not ill, the four constables died from a short putrid fever; but the contagion extended to no others. From these facts it would almost appear as if the effluvium of one set of men shut up for some time together was poisonous when inhaled by others, and possibly more so, if the men be of different races. Mysterious as this circumstance appears to be, it is not more surprising than that the body of one's fellow-creature, directly after death, and before putrefaction has commenced, should often be of so deleterious a quality, that the mere puncture from an instrument used in its dissection should prove fatal.

17th.-Early in the morning we passed the Nepean in a ferry-boat. The river, although at this spot both broad and deep, had a very small body of running water. Having crossed a low piece of land on the opposite side, we reached the slope of the Blue Mountains. The ascent is not steep, the road having been cut with much care on

that the great epidemics at Panama and Callao are "marked" by the arrival of ships from Chile, because the people from that temperate region first experience the fatal effects of the torrid zones. $I$ may add, that I have heard it stated in Shropshire, that sheep, which have been imported from vessels, although themselves in a healthy condition, if placed in the same fold with others, frequently produce sickness in the flock. 
the side of a sandstone cliff. On the summit an almost level plain extends, which, rising imperceptibly to the westward, at last attains a height of more than 3000 feet. From so grand a title as Blue Mountains, and from their absolute altitude, I expected to have seen a bold chain of mountains crossing the country; but, instead of this, a sloping plain presents merely an inconsiderable front to the low land near the coast. From this first slope, the view of the extensive woodland to the east was striking, and the surrounding trees grew bold and lofty. But when once on the sandstone platform, the scenery becomes exceedingly monotonous; each side of the road is bordered by scrubby trees of the never-failing Eucalyptus family; and with the exception of two or three small inns, there are no houses or cultivated land: the road, moreover, is solitary; the most frequent object being a bullock-wagon, piled up with bales of wool.

In the middle of the day we baited our horses at a little inn called the Weatherboard. The country here is elevated 2800 feet above the sea. About a mile and a half from this place there is a view exceedingly well worth visiting. Following down a little valley and its tiny rill of water, an immense gulf unexpectedly opens through the trees which border the pathway, at the depth of perhaps 1500 feet. Walking on a few yards, one stands on the brink of a vast precipicc, and below one sees a grand bay or gulf, for I know not what other name to give it, thickly covered with forest. The point of view is situated as if at the head of a bay, the line of cliff diverging on each side, and showing headland behind headland, as on a bold sea-coast. These cliffs are composed of horizontal strata of whitish sandstone, and are so absolutely vertical, that in many places a person standing on the edge 
and throwing down a stone can see it strike the trees in the abyss below. So unbroken is the line of cliff, that in order to reach the foot of the waterfall, formed by this little stream, it is said to be necessary to go sixteen miles round. About five miles distant in front, another line of cliff extends, which thus appears completely to encircle the valley; and hence the name of bay is justified, as applied to this grand amphitheatrical depression. If we imagine a winding harbour, with its deep water surrounded by bold cliff-like shores, to be laid dry, and a forest to spring up on its sandy bottom, we should then have the appearance and structure here exhibited. This kind of view was to me quite novel and extremely magnificent.

In the evening we-reached the Blackheath. The sandstone plateau has here attained the height of 3400 feet, and is covered, as before, with the same scrubby woods. From the road, there were occasional glimpses into a profound valley, of the same character as the one described; but from the steepness and depth of its sides, the bottom was scarcely ever to be seen. The Blackheath is a very comfortable inn, kept by an old soldier; and it reminded me of the small inns in North Wales.

18th.-Very early in the morning I walked about three miles to see Govett's Leap : a view of a similar character with that near the Weatherboard, but perhaps even more stupendous. So early in the day the gulf was filled with a thin blue haze, which, although destroying the general effect of the view, added to the apparent depth at which the forest was stretched out beneath our feet. These valleys, which so long presented an insuperable barrier to the attempts of the most enterprising of the colonists to reach the interior, are most remarkable. Great arm-like bays, expanding 
at their upper ends, often branch from the main valleys and penetrate the sandstone platform; on the other hand, the platform often sends promontories into the valleys, and even leaves in them great, almost insulated, masses. To descend into some of these valleys, it is necessary to go round twenty miles; and into others, the surveyors have only lately penetrated, and the colonists have not yet been able to drive in their cattle. But the most remarkable feature in their structure is, that although several miles wide at their heads, they generally contract towards their mouths to such a degree as to become impassable. The surveyorgeneral, Sir T. Mitchell,* endeavoured in vain, first walking, and then by crawling between the great, fallen fragments of sandstone, to ascend through the gorge by which the river Grose joins the Nepean; yet the valley of the Grose in its upper part, as I saw, forms a magnificent level basin some miles in width, and is on all sides surrounded by cliffs, the summits of which are believed to be nowhere less than 3000 feet above the level of the sea. When cattle are driven into the valley of the Wolgan by a path (which I descended), partly natural and partly made by the owner of the land, they cannot escape; for this valley is in every other part surrounded by perpendicular cliffs, and eight miles lower down it contracts from an average width of half a mile to a mere chasm, impassable to man or beast. Sir T. Mitchell states that the great valley of the Cox river, with all its branches, contracts, where it unites with the Nepean, into a gorge twenty-two hundred yards in width, and

* Travels in Australia, vol. i., p. 154. I must express my obligation to Sir T. Mitchell for several interesting personal communications on the subject of these great valleys of New South Wales. 
about one thousand feet in depth. Other similar cases might have been added.

The first impression on seeing the correspondence of the horizontal strata on each side of these valleys and great amphitheatrical depressions is, that they have been hollowed out, like other valleys, by the action of water; but when one reflects on the enormous amount of stone which, on this view, must have been removed through mere gorges or chasms, one is led to ask whether these spaces may not have subsided; but, considering the form of the irregularly branching valleys, and of the narrow promontories projecting into them from the platforms, we are compelled to abandon this notion. To attribute these hollows to the present alluvial action would be preposterous ; nor does the drainage from the summit-level always fall, as I remarked near the Weatherboard, into the head of these valleys, but into one side of their bay-like recesses. Some of the inhabitants remarked to me that they never viewed one of those bay-like recesses, with the headlands receding on both hands, without being struck with their resemblance to a bold sea-coast. This is certainly the case; moreover, on the present coast of New South Wales, the numerous fine, widely-branching harbours, which are generally connected with the sea by a narrow mouth worn through the sandstone coast-cliffs, varying from one mile in width to a quarter of a mile, present a likeness, though on a miniature scale, to the great valleys of the interior. But then immediately occurs the startling difficulty, why has the sea worn out these great, though circumscribed depressions on a wide platform, and left mere gorges at the openings, through which the whole vast amount of triturated matter must have been carried away? The only light I II. 
can throw upon this enigma is by remarking, that banks of the most irregular forms appear to be now forming in some seas, as in parts of the West Indies and in the Red Sea, and that their sides are exceedingly steep. Such banks, I have been led to suppose, have been formed by sediment heaped by strong currents on an irregular bottom. That in some cases the sea, instead of spreading out sediment in a uniform sheet, heaps it round submarine rocks and islands, it is hardly possible to doubt, after examining the charts of the IVest Indies; and that the waves have power to form high and precipitous cliffs, even in land-locked harbours, I have noticed in many parts of South America. To apply these ideas to the sandstone platforms of New South WVales, I imagine that the strata were heaped by the action of strong currents, and of the undulations of an open sea, on an irregular bottom; and that the valley-like spaces thus left unfilled had their steeply sloping flanks worn into cliffs during a slow elevation of the land; the worn-down sandstone being removed, either at the time when the narrow gorges were cut by the retreating sea, or subsequently by alluvial action.

Soon after leaving the Blackheath, we descended from the sandstone platform by the pass of Mount Victoria. To effect this pass, an enormous quantity of stone has been cut through; the design, and its manner of execution, being worthy of any line of road in England. We now entered upon a country less elevated by nearly a thousand feet, and consisting of granite. With the change of rock the vegetation improved; the trees were both finer and stood farther apart; and the pasture between them was a little greener and more plentiful. At Hassan's Walls I left the high road, and 
made a short détour to a farm called Walerawang, to the superintendent of which I had a letter of introduction from the owner in Sydney. Mr. Browne had the kindness to ask me to stay the ensuing day, which I had much pleasure in doing. This place offers an example of one of the large farming, or, rather, sheep-grazing establishments of the colony. Cattle and horses are, however, in this case rather more numerous than usual, owing to some of the valleys being swampy and producing a coarser pasture. Two or three flat pieces of ground near the house were cleared and cultivated with corn, which the harvest-men were now reaping; but no more wheat is sown than sufficient for the annual support of the labourers employed on the establishment. The usual number of assigned convict-servants here is about forty, but at the present time there were rather-more. Although the farm was well stocked with every necessary, there was an apparent absence of comfort, and not one single woman resided here. The sunset of a fine day will generally cast an air of happy contentment on any scene; but here, at this retired farm-house, the brightest tints on the surrounding woods could not make me forget that forty hardened, profligate men were ceasing from their daily labours, like the slaves from Africa, yet without their holy claim for compassion.

Early on the next morning, Mr. Archer, the joint superintendent, had the kindness to take me out kangaroo-hunting. We continued riding the greater part of the day, but had very bad sport, not seeing a kangaroo, or even a wild dog. The greyhounds pursued a kangaroo rat into a hollow tree, out of which we dragged it: it is an animal as large as a rabbit, but with the figure of a kangaroo. A few years since this country abounded 
with wild animals; but now the emu is banished to a long distance, and the kangaroo is become scarce: to both the English greyhound has been highly destructive. It may be long before these animals are altogether exterminated, but their doom is fixed. The aborigines are always anxious to borrow the dogs from the farm-houses : the use of them, the offal when an animal is killed, and some milk from the cows, are the peace-offerings of the settlers, who push farther and farther towards the interior: The thoughtless aboriginal, blinded by these trifling advantages, is delighted at the approach of the white man, who seems predestined to inberit the country of his children.

Although having poor sport, we enjoyed a pleasant ride. The woodland is generally so open that a person on horseback can gallop through it. It is traversed by a few flat-bottomed valleys, which are green and free from trees: in such spots the scenery was pretty, like that of a park. In the whole country I scarcely saw a place without the marks of a fire; whether these had been more or less recent-whether the stumps were more or less black-was the greatest change which varied the uniformity, so wearisome to the traveller's eye. In these woods there are not many birds; I saw, however, some large flocks of the white cockatoo feeding in a corn-field, and a few most beautiful parrots; crows like our jackdaws were not uncommon, and another bird something like the magpie. In the dusk of the evening 1 took a stroll along a chain of ponds, which in this dry country represented the course of a river, and had the good fortune to see several of the famous Ornithorhynchus paradoxus. They were diving and playing about the surface of the water, but showed so little of their bodies that they might easily have 
been mistaken for water-rats. Mr. Browne shot one: certainly it is a most extraordinary animal; a stuffed specimen does not at all give a good idea of the appearance of the head and beak when fresh, the latter becoming hard and contracted.*

20th.-A long day's ride to Bathurst. Before joining the high road we followed a mere path through the forest, and the country, with the exception of a few squatters' huts, was very solitary. IVe experienced this day the sirocco-like wind of Australia, which comes from the parched deserts of the interior. Clouds of dust were travelling in every direction, and the wind felt as if it had passed over a fire. I afterwards heard that the thermometer out of doors had stood at $119^{\circ}$, and in a closed room at $96^{\circ}$. In the afternoon we came in view of the downs of Bathurst. These undulating but nearly smooth plains are very remarkable in this country, from being absolutely destitute of trees. They support only a thin, brown pasture. We rode some miles over this country, and then reached the township of Bathurst, seated in the middle of what may be called either a very broad valley or narrow plain. I was told at Sydney not to form too bad an opinion of Australia by judging of the country from the road-side, nor too good a one from Bathurst; in this latter respect I did not feel myself in the least danger of being prejudiced.

* I was interested by finding here the hollow, conical pitfall of the lion-ant, or some other insect: first a fly fell down the treacherous slope and immediately disappeared; then came a large but unwary ant; its struggles to escape being very violent, those curious little jets of sand, described by Kirby and Spence (Entomol., vol. i., p. 425) as being flirted by the insect's tail, were promptly directed against the expected victim. But the ant enjoyed a better fate than the fly, and escaped the fatal jaws which lay concealed at the base of the conical hollow. This Australian pitfall was only about half the size of that made by the European lionant.

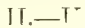


The season, it must be owned, had been one of great drought, and the country did not wear a favourable aspect, although I understand it was incomparably worse two or three months before. The secret of the rapidly-growing prosperity of Bathurst is, that the brown pasture, which appears to the stranger's eye so wretched, is excellent for sheep-grazing. The town stands, at the height of 2200 feet above the sea, on the banks of the Macquarie: this is one of the rivers flowing into the vast and scarcely-known interior. The line of water-shed, which divides the inland streams from those on the coast, has a height of about 3000 feet, and runs in a north and south direction at the distance of from eighty to a hundred miles from the sea-side. The Macquarie figures in the map as a respectable river, and it is the largest of those draining this part of the water-shed; yet, to my surprise, I found it a mere chain of ponds, separated from each other by spaces almost dry. Generally a small stream is running, and sometimes there are high and impetuous floods. Scanty as the supply of the water is throughout this district, it becomes still scantier further inland.

$22 d$.- I commenced my return, and followed a new road called Lockyer's Line, along which the country is rather more hilly and picturesque. This was a long day's ride, and the house where I wished to sleep was some way off the road, and not easily found. I met on this occasion, and indeed on all others, a very general and ready civility among the lower orders, which, when one considers what they are and what they have been, would scarcely have been expected. The farm where I passed the night was owned by two young men who had only lately come out, and were beginning a settler's life. The total want of almost every 
comfurt was not very attractive; but future and certain prosperity was before their eyes, and that not far distant.

The next day we passed through large tracts of country in flames, volumes of smoke sweeping across the road. Before noon we joined our former road, and ascended Mount Victoria. I slept at the Weatherboard, and before dark took another walk to the amphitheatre. On the road to Sydney I spent a very pleasant evening with Captain King at Dunheved, and thus ended my little excursion in the colony of New South Wales.

Before arriving here, the three things which interested me most were, the state of society amongst the higher classes, the condition of the convicts, and the degree of attraction sufficient to induce persons to emigrate. Of course, after so very short a visit, one's opinion is worth scarcely anything; but it is as difficult not to form some opinion as it is to form a correct judgment. On the whole, from what I heard more than from what I saw, I was disappointed in the state of society. The whole community is rancorously divided into parties on almost every subject. Amongst those who, from their station in life, ought to be the best, many live in such open profligacy that respectable people cannot associate with them. There is much jealousy between the children of the rich emancipist and the free settlers, the former being pleased to consider honest men as interlopers. The whole population, poor and rich, are bent on acquiring wealth: amongst the higher orders, wool and sheep-grazing form the constant subject of conversation. There are many serious drawbacks to the comforts of a family, the chief of which, perhaps, is being surrounded by convict servants. How thoroughly odious to every feeling to be waited on by a man 
who the day before, perhaps, was flogged, from your representation, for some trifling misdemeanour. The female servants are, of course, much worse: hence children learn the vilest expressions, and it is fortunate if not equally vile ideas.

On the other hand, the capital of a person, without any trouble on his part, produces him treble interest to what it would in England, and with care he is sure to grow rich. The luxuries of life are in abundance, and very little dearer than in England, and most articles of food are cheaper. The climate is splendid and perfectly healthy ; but, to my mind, its charms are lost by the uninviting aspect of the country. Settlers possess a great advantage in finding their sons of service when very young. At the age of from sixteen to twenty, they frequently take charge of distant farming stations. This, however, must happen at the expense of their boys associating entirely with convict servants. I am not aware that the tone of society has assumed any peculiar character; but with such habits, and without intellectual pursuits, it can hardly fail to deteriorate. My opinion is such, that nothing but rather sharp necessity should compel me to emigrate.

The rapid prosperity and future prospects of this colony are to me, not understanding these subjects, very puzzling. The two main exports are wool and whale-oil, and to both of these productions there is a limit. The country is totally unfit for canals; therefore there is a not very distant point, beyond which the land-carriage of wool will not repay the expense of shearing and tending sheep. Pasture everywhere is so thin that settlers liave already pushed far into the interior: moreover, the country further inland becomes extremely poor. Agriculture, on account of the droughts, can never 
succeed on an extended scale; therefore, so far as I can see, Australia must ultimately depend upon being the centre of commerce for the southern hemisphere, and perhaps on her future manufactories. Possessing coal, she always has the moving power at hand. From the habitable country extending along the coast, and from her English extraction, she is sure to be a maritime nation. I formerly imagined that Australia would rise to be as grand and powerful a country as North America, but now it appears to me that such future grandeur is rather problematical.

With respect to the state of the convicts, I had still fewer opportunities of judging than on the other points. The first question is, whether their condition is at all one of punishment: no one will maintain that it is a very severe one. This, however, I suppose, is of little consequence as long as it continues to be an object of dread to criminals at home. The corporeal wants of the convicts are tolerably well supplied: their prospect of future liberty and comfort is not distant, and, after good conduct, certain. A "ticket of leave," which, as long as a man keeps clear of suspicion as well as of crime, makes him fiee within a certain district, is given upon good conduct, after years proportional to the length of the sentence; yet with all this, and overlooking the previous imprisonment and wretched passage out, I believe the years of assignment are passed away with discontent and unhappiness. As an intelligent man remarked to me, the convicts know no pleasure beyond sensuality, and in this they are not gratified. The enormous bribe which government possesses in offering free pardons, together with the deep horror of the secluded penal settlements, destroys confidence between the convicts, and so prevents crime. As to a sense of shame, 
such a feeling does not appear to be known, and of this I witnessed some vory singular proofs. Though it is a curious fact, I was universally told that the character of the convict population is one of arrant cowardice: not unfrequently some become desperate, and quite indifferent as to life, yet a plan requiring cool or continued courage is seldom put into execution. The worst feature in the whole case is, that although there exists what may be called a legal reform, and comparatively little is committed which the law can touch, yet that any moral reform should take place appears to be quite out of the question. I was assured by well-informed people that a man who should try to improve could not, while living with other assigned servants; his life would be one of intolerable misery and persecution. Nor must the contamination of the convict-ships and prisons, both here and in England, be forgotten. On the whole, as a place of punishment, the object is scarcely gained; as a real system of reform it has failed, as perhaps would every other plan; but as a means of making men outwardly honest, of converting vagabonds, most useless in one hemisphere, into active citizens of another, and thus giving birth to a new and splendid country - a grand centre of civilization - it has succeeded to a degree perhaps unparalleled in history.

30th-The Beagle sailed for Hobart Town in Van Diemen's Land. On the 5th of February, after a. six days' passage, of which the first part was fine, and the latter very cold and squally, we entered the mouth of Storm Bay: the weather justified this awful name. The bay should rather be called an estuary, for it receives at its head the waters of the Derwent. Near the mouth there are 
some extensive basaltic platforms, but higher up the land becomes mountainous, and is covered by a light wood. The lower parts of the hills which skirt the bay are cleared, and the bright yellow fields of corn, and dark green ones of potatoes, appeared very luxuriant. Late in the evening we anchored in the snug cove, on the shores of which stands the capital of Tasmania. The first aspect of the place was very inferior to that of Sydney; the latter might be called a city, this only a town. It stands at the base of Mount Wellington, a mountain 3100 feet high, but of little picturesque beauty : from this source, however, it receives a good supply of water. Round the cove there are some fine warehouses, and on one side a small fort. Coming from the Spanish settlements, where such magnificent care has generally been paid to the fortifications, the means of defence in these colonies appeared very contemptible. Comparing the town with Sydney, I was chiefly struck with the comparative fewness of the large houses, either built or building. Hobart Town, from the census of 1835 , contained 13,826 inhabitants, and the whole of Tasmania 36,505.

All the aborigines have been removed to an island in Bass's Straits, so that Van Diemen's Land enjoys the great advantage of being free from a native population. This most cruel step seems to have been quite unavoidable, as the only means of stopping a fearful succession of robberies, burnings, and murders committed by the blacks, and which sooner or later would have ended in their utter destruction. I fear there is no doubt that this train of evil and its consequences originated in the infamous conduct of some of our countrymen. Thirty years is a short period in which to have banished the last aboriginal from his native 
island, and that island nearly as large as Ireland. The correspondence on this subject, which took place between the government at home and that of Van Diemen's Land, is very interesting. Although numbers of natives were shot and taken prisoners in the skirmishing, which was going on at intervals for several years, nothing seems fully to have impressed them with the idea of our overwhelming power, until the whole island, in 1830, was put under martial law, and by proclamation the whole population commanded to assist in one great attempt to secure the entire race. The plan adopted was nearly similar to that of the great hunting-matches in India : a line was formed reaching across the island, with the intention of driving the natives into a cul-de-sac on Tasman's peninsula. The attempt failed; the natives, having tied up their dogs, stole during one night through the lines. This is far from surprising when their practised senses and usual manner of crawling after wild animals is considered. I have been assured that they can conceal themselves on almost bare ground, in a manner which, until witnessed, is scarcely credible, their dusky bodies being easily mistaken for the blackened stumps which are scattered all over the country. I was told of a trial between a party of Englishmen and a native, who was to stand in full view on the side of a bare hill ; if the Englishmen closed their eyes for less than a minute, he would squat down, and then they were never able to distinguish him from the surrounding stumps. But to return to the hunting-match: the natives, understanding this kind of warfare, were terribly alarmed, for they at once perceived the power and numbers of the whites. Shortly afterwards a party of thirteen, belonging to two tribes, came in, and, conscious of their unprotected condition, delivered 
themselves up in despair. Subsequently, by the intrepid exertions of Mr. Robinson, an active and benevolent man, who fearlessly visited by himself the most hostile of the natives, the whole were induced to act in a similar manner. They were then removed to an island, where food and clothes were provided them. Count Strzelecki states,* that, "at the epoch of their deportation in 1835 , the number of natives amounted to 210 . In 1842 , that is, after the interval of seven years, they mustered only fifty-four individuals; and, while each family of the interior of New South Wales, uncontaminated by contact with the whites, swarms with children, those of Flinders' Island had, during eight years, an accession of only fourteen in number!"”

The Beagle stayed here ten days, and in this time I made several pleasant little excursions, chiefly with the object of examining the geological structure of the immediate neighbourhood. The main points of interest consist, first, in some highly fossiliferous strata, belonging to the Devonian or Carboniferous period; secondly, in proofs of a late small rise of the land; and lastly, in a solitary and superficial patch of yellowish limestone or travertin, which contains numerous impressions of leaves of trees, together with land-shells, not now existing. It is not improbable that this one small quarry includes the only remaining record of the vegetation of Van Diemen's Land during one former epoch.

The climate here is damper than in New South Wales, and hence the land is more fertile. Agriculture flourishes: the cultivated fields look well, and the gardens abound with thriving vegetables and fruit-trees. Some of the farm-houses, situated

* Physical Description of New South Wales and Van Diemen's Land, p. 354. 
in retired spots, had a very attractive appearance. 'The general aspect of the vegetation is similar to that of Australia; perhaps it is a little more green and cheerful, and the pasture between the trees rather more abundant. One day I took a long walk on the side of the bay opposite to the town; 1 crossed in a steamboat, two of which are constantly plying backwarls and forwards. The machinery of one of these ressels was entirely manufactured in this colony, which, from its very foundation, then numbered only three-and-thirty years! Another day I ascended Mount Wellington; I took with me a guide, for I failed in a first attempt, fiom the thickness of the wood. Our guide, however, was a stupid fellow, and conducted us to the sonthern and damp' side of the mountain, where the vegetation was very luxuriant, and where the labour of the ascent, from the number of rotten trunks, was almost as great as on a mountain in Tierra del Fuego or in Chiloe. It cost us five and a half hours of hard climbing before we reacherl the summit. In many parts the Encalypti grew to a great size, and composed a noble forest. In some of the dampest ravines tree-ferns flourished in an extraordinary mamner; I saw one which must have boen at least twenty feet high to the base of the fronds, and was in girth exactly six feet. The fronds, forming the most elegant parasols, produced a gloomy shade, like that of the first hour of night. The summit of the mountain is broad and flat, and is composed of huge angular masses of naked greenstone. Its elevation is 3100 feet above the level of the sea. The day was splendidly clear, and we enjoyed a most extensive view; to the north, the country appeared a mass of wooded mountains, of about the same height with that on which we were standing, and with an equally tame outline; to the 
south, the broken land and water, forming many intricate bays, was mapped with clearness before us. After staying some hours on the summit, we found a better way to descend, but did not reach the Beagle till eight o'clock, after a severe day's work.

February 7th.-The Beagle sailed from Tasmania, and, on the 6th of the ensuing month, reached King George's Sound, situated close to the S.W. corner of Australia. We stayed there eight days, and we did not, during our voyage, pass a more dull and uninteresting time. The country, viewed from an eminence, appears a woody plain, with here and there rounded and partly bare hills of granite protruding. One day I went out with a party, in hopes of seeing a kangaroo-hunt, and walked over a good many miles of country. Everywhere we found the soil sandy and very poor: it supported either a coarse vegetation of thin, low brushwood and wiry grass, or a forest of stunted trees. The scenery resembled that of the high sandstone platform of the Blue Mountains ; the Casuarina (a tree somewhat resembling a Scotch fir) is, however, here in greater number, and the Eucalyptus in rather less. In the open parts there were many grass-treesa plant which, in appearance, has some affinity with the palm; but, instead of being surmounted by a crown of noble fronds, it can boast merely of a tuft of very coarse grass-like leaves. The general bright green colour of the brushwood and other plants, viewed from a distance, seemed to promise fertility. A single walk, however, was enough to dispel such an illusion; and he who thinks with me will never wish to walk again in so uninviting a country.

One day I accompanied Captain Fitz Roy to Bald Head, the place mentioned by so many navigators, where some imagined that they saw corals, and 
others that they saw petrified trees, standing in the position in which they had grown. According to our view, the beds have been formed by the wind having heaped up fine sand, composed of minute rounded particles of shells and corals, during which process branches and roots of trees, together with many land-shells, became enclosed. The whole then became consolidated by the percolation of calcareous matter; and the cylindrical cavities left by the decaying of the wood were thus also filled up with a hard pseudo-stalactitical stone. The weather is now wearing away the softer parts, and, in consequence, the hard casts of the roots and branches of the trees project above the surface, and in a singularly deceptive manner resemble the stumps of a dead thicket.

$\Lambda$ large tribe of natives, called the White Cockatoo men, happened to pay the settlement a visit while we were there. These men, as well as those of the tribe belonging to King George's Sound, being tempted by the offer of some tubs of rice and sugar, were persuaded to hold a "corrobery," or great dancing party. As soon as it grew dark, small fires were lighted, and the men commenced their toilet, which consisted in painting themselves white in spots and lines. As soon as all was ready, large fires were kept blazing, round which the women and children were collected as spectators; the Cockatoo and King George's men formed two distinct parties, and generally danced in answer to each other. 'The dancing consisted in their running either sideways or in Indian file into an open space, and stamping the ground with great force as they marched together. Their heavy footsteps were accompanied by a kind of grunt, by beating their clubs and spears together, and by various other gesticulations, such as extending their arms and wriggling 
their bodies. It vras a most rude, barbarous scene, and, to our ideas, without any sort of meaning; but we observed that the black women and children watched it with the greatest pleasure. Perhaps these dances originally represented actions, such as wars and victories; there was one called the Emu dance, in which each man extended his arm in a bent manner, like the neck of that bird. In another dance, one man imitated the movements of a kangaroo grazing in the woods, whilst a second crawled up and pretended to spear him. When both tribes mingled in the dance, the ground trembled with the heaviness of their steps, and the air resounded with their wild cries. Every one appeared in high spirits, and the group of nearly naked figures, viewed by the light of the blazing fires, all moving in hideous harmony, formed a perfect display of a festival amongst the lowest barbarians. In Tierra del Fuego, we have beheld many curious scenes in savage life, but never, I think, one where the natives were in such high spirits, and so perfectly at their ease. After the dancing was over, the whole party formed a great circle on the gromnd, and the boiled rice and sugar was distributed, to the delight of all.

After several tedious delays from clouded weather, on the 14th of March we gladly stood ont of King George's Sound on our course to Keeling Island. Farewell, Australia ! you are a rising child, and doubtless some day will reign a great princess in the South; but you are too great and ambitious for affection, yet not great enough for respect. I leave your shores without sorrow or regret. II. 


\section{CHAPTER VIII.}

Keeling Island-Singular A ppearance-Scanty Flora-Transport of seeds-Birds and Insects-Fbbing and Flowing SpringsFields of dearl Coral - Stones transported in the Roots of T'rees _Cireat Crab_-stiuging Corals-Coral-eating Fish-Coral Formations-Lagoon Islands or Atolls-Depth at which reef-buildmig Corals can live- Vast Areas interspersed with low Coral Islands-subsidence of their Foundations-Barrier ReefsFringing Reefs-Conversion of Fringing Reefs into Barrier Reets and into Atolls-Evidence of Changes in Level-Breaches iu Barrier Reefs-Maldiva Atolls; their peculiar StructureDead and submerged Reefs-Areas of Subsidence and Elevation-Distribution of Volcanoes-Subsidence Slow, and vast in Amount.

KEELING ISLAND-CORAL FORMATIONS.

April 1st.- $W_{\mathrm{E}}$ arrived in view of the Keeling or Crcos Islands, situated in the Indian Ocean, and about six hundred miles distant from the coast of Sumatra. This is one of the lagoon-islands (or atolls) of coral formation, similar to those in the Low Archipelago which we passed near. When the ship was in the chanuel at the entrance, Mr. Liesk, an English resident, came off in his boat. The history of the inhabitants of this place, in as few words as possible, is as follows. About nine years ago, Mr. Hare, a worthless cliaracter, brought from the East Indian Archipelago a number of Malay slaves, which now, including children, amount to more than a hundred. Shortly afterwards, Captain Ross, who had before visited these islands in his merchant-ship, arrived from England, bringing with him his family and goods for settlement : along with him came Mr. Liesk, who had been a mate in his vessel. The Malay slaves soon ran away from the islet on which Mr. Hare was settled, and join- 
ed Captain Ross's party. Mr. Hare, upon this, was ultimately obliged to leave the place.

The Malays are now nominally in a state of freedom, and certainly are so, as far as regards their personal treatment; but in most other points they are considered as slaves. From their discontented state, from the repeated removals from islet to islet, and perhaps also from a little mismanagement, things are not very prosperous. The island has no domestic quadruped excepting the pig, and the main vegetable production is the cocoa-nut. The whole prosperity of the place depends on this tree: the only exports being oil from the nut, and the nuts themselres, which are taken to Singapore and Mauritius, where they are chiefly used, when grated, in making curries. On the cocoa-nut, also, the pigs, which are loaded with fat, almost entirely subsist, as do the ducks and poultry. Even a liuge land-crab is furnished by nature with the means to open and feed on this most useful production.

The ring-formed reef of the lagoon-island is surmounted in the greater part of its length by linear islets. On the northern or leeward side there is an opening through which vessels can pass to the anchorage within. On entering, the scene was very curious and rather pretty; its beauty, however, entirely depended on the brilliancy of the surrounding colours. The shallow, clear, and still water of the lagoon, resting in its greater part on white sand, is, when illumined by a vertical sun, of the most vivid green. This brilliant expanse, several miles in width, is on all sides divided, either by a line of snow-white breakers from the dark heaving waters of the ocean, or from the blue vault of heaven by the strips of land, crowned by the level tops of the cocoa-nut trees. As a white cloud here and 
there affords a pleasing contrast with the azure sky, so in the lagoon, bands of living coral darken the emerald green water.

The next morning, after anchoring, I went on shore on Direction Island. The strip of dry land is only a few hundred yards in width; on the lagoon side there is a white calcareous beach, the radiation from which under this sultry climate was very oppressive; and on the outer coast, a solid, broad flat of coral-rock served to break the violence of the open sea. Excepting near the lagoon, where there is some sand, the land is entirely composed of rounded fragments of coral. In such a loose, dry, stony soil, the climate of the intertropical regions alone could produce a vigorous vegetation. On some of the smaller islets, nothing could be more elegant than the manner in which the young and full-grown cocoa-nut trees, without destroying each other's symmetry, were mingled into one wood. A beach of glittering white sand formed a border to these fairy spots.

I will now give a sketch of the natural history of these islands, which, from its very paucity, possesses a peculiar interest. The cocoa-nut tree, at the first glance, seems to compose the whole wood; there are, however, five or six other trees. One of these grows to a very large size, but, from the extreme softness of its wood, is useless; another sort affords excellent timber for ship-building. Besides the trees, the number of plants is exceedingly limited, and consists of insignificant weeds. In my collection, which includes, I believe, nearly the perfect Flora, there are twenty species, without reckoning a moss, lichen, and fungus. To this number two trees must be added, one of which was not in flower, and the other I only heard of. The latter is a solitary tree of its kind, and grows 
near the beach, where, without doubt, the one seed was thrown up by the waves. A Guilandina also grows on only one of the islets. I do not include in the above list the sugar-cane, banana, some other vegetables, fruit-trees, and imported grasses. As the islands consist entirely of coral, and at one time must have existed as mere water-washed reefs, all their terrestrial productions must have been transported here by the waves of the sea. In accordance with this, the Florula has quite the character of a refuge for the destitute: Professor Henslow informs me, that of the twenty species, nineteen belong to different genera, and these, again, to no less than sixteen families!*

In Holman's† Travels an account is given, on the authority of Mr. A. S. Keating, who resided twelve months on these islands, of the various seeds and other bodies which have been known to have been washed on shore. "Seeds and plants from Sumatra and Java have been driven up by the surf on the windward side of the islands. Among them have been found the Kimiri, native of Sumatra and the peninsula of Malacca; the cocoa-nut of Balci, known by its shape and size; the Dadass, which is planted by the Malays with the pepper-vine, the latter intwining round its trunk, and supporting itself by the prickles on its stem; the soap-tree; the castor-oil plant; trunks of the sago palm; and various kinds of seeds unknown to the Malays settled on the islands. These are all supposed to have been driven by the N.W. monsoon to the coast of New Holland, and thence to these islands by the S.E. trade-wind. Large masses of Java teak and Yellow wood have also been found, besides im-

* These plants are described in the Annals of Nat. Hist., vol. i., 1838 , p. 337 .

† Holman's Travels, vol. iv., p. 378. 
mense trees of red and white cedar, and the blue gum-wood of New Holland, in a perfectly sound condition. All the hardy seeds, such as creepers, retain their germinating power, but the softer kinds, among which is the mangostin, are destroyed in the passage. Fishing-canoes, apparently from Java, have at times been washed on shore." It is interesting thus to discover how numerous the seeds are, which, coming from several countries, are drifted over the wide ocean. Professor Henslow telis me, he believes that nearly all the plants which I brought from these islands are common littoral species in the East Indian Archipelago. From the direction, however, of the winds and currents, it seems scarcely possible that they could have come here in a direct line. If, as suggested with much probability by Mr. Keating, they were first carried towards the coast of New Holland, and thence drifted back together with the productions of that country, the seeds, before germinating, must have travelled between 1800 and 2400 miles.

Chamisso, ${ }^{*}$ when describing the Radack Archipelago, situated in the western part of the Pacific, states that "the sea brings to these islands the seeds and fruits of many trees, most of which have yet not grown here. The greater part of these seeds appear to have not yet lost the capability of growing." It is also said that palms and bamboos from somewhere in the torrid zone, and trunks of northern firs, are washed on shore: these firs must have come from an immense distance. These facts are highly interesting. It cannot be doubted that if there were land-birds to pick up the seeds when first cast on shore, and a soil better adapted for their growth than the loose blocks of coral, that the most isolated of the lagoon-islands would in time possess a far more abundant Flora than they now have.

* Kotzebue's Frrst Voyage, rol. nii., v. 155. 
The list of land animals is even poorer than that of the plants. Some of the islets are inhabited by rats, which were brought in a ship from the Mauritius, wrecked here. These rats are considered by Mr. Waterhouse as identical with the English kind, but they are smaller, and more brightly coloured. There are no true land-birds; for a snipe and a rail (Rallus Phillippensis), though living entirely in the dry herbage, belong to the order of Waders. Birds of this order are said to occur on several of the small low islands in the Pacific. At Ascension, where there is no land-bird, a rail (Porphyrio simplex) was shot near the summit of the mountain, and it was evidently a solitary straggler. At 'Tristan d'Acunha, where, according to Carmichael, there are only two land-birds, there is a coot. From these facts, I believe that the Waders, after the innumerable web-footed species, are generally the first colonists of small isolated islands. I may add, that whenever I noticed birds, not of oceanic species, very far out at sea, they always belonged to this order, and hence they would naturally become the earliest colonists of any remote point of land.

Of reptiles I saw only one small lizard. Of insects I took pains to collect every kind. Exclusive of spiders, which were numerous, there were thirteen species.* Of these, one only was a beetle. A small ant swarmed by thousands under the loose dry blocks of coral, and was the only true insect which was abundant. Although the productions of the land are thus scanty, if we look to the waters of the surrounding sea, the number of organic beings

* The thirteen species belong to the following orders: In the Coleoptera, a minute Elater; Orthoptera, a Gryllus and a Blatta; Hemiptera, one species ; Homoptera, two; Neuroptera, a Chrysopa ; Hymenoptera, two ants; Lepidoptera nocturna, a Diopæa and a Pterophorus (?); Diptera, two species. 
is indeed infinite. Chamisso has described* the natural history of a lagoon-island in the Radack Archipelago, and it is remarkable how closely its inhabitants, in number and kind, resemble those of Keeling Island. There is one lizard and two waders, namely, a snipe and curlew. Of plants there are nineteen species, including a fern; and some of these are the same with those growing here, thongh on a spot so immensely remote, and in a different ocean.

The long strips of land, forming the linear islets, have been raised only to that height to which the surf can throw fragments of coral, and the wind heap up calcareous sand. The solid flat of coral rock on the outside, by its breadth, breaks the first violence of the waves, which otherwise, in a day, would sweep away these islets and all their productions. The ocean and the land seem here struggling for mastery : although terra firma has obtained a footing, the denizens of the water think their claim at least equally good. In every part one meets hermit-crabs of more than one species, $\dagger$ carrying on their backs the shells which they have stolen from the neighbouring beach. Overhead, numerous gannets, frigate-birds, and terns, rest on the trees; and the wood, from the many nests and from the smell of the atmosphere, might be called a sea-rookery. The gannets, sitting on their rude nests, gaze at one with a stupid yet angry air. The noddies, as their name expresses, are silly litthe creatures. But there is one charming bird: it

* Kotzebue's First Voyage, vol. iii., p. 222.

t The large claws or pincers of some of these crabs are most beautifully adapted, when drawn back, to form an operculum to the shell, nearly as perfect as the proper one originally belonging to the molluscous animal. I was assured, and, as far as my observation went, I found it so, that certain species of the hermitcrabs always use certain species of shells. 
is a small snow-white tern, which smoothly hovers at the distance of a few feet above one's head, its large black eye scanning, with quiet curiosity, your expression. Little imagination is required to fancy that so light and delicate a body must be tenanted by some wandering fairy spirit.

Sunday, April 3d.-After service I accompanied Captain Fitz Roy to the settlement, situated at the distance of some miles, on the point of an islet thickly covered with tall cocoa-nut trees. Captain Ross and Mr. Liesk live in a large barn-like house, open at both ends, and lined with mats made of woven bark. The houses of the Malays are arranged along the shore of the lagoon. The whole place had rather a desolate aspect, for there were no gardens to show the signs of care and cultivation. The natives belong to different islands in the East Indian Archipelago, but all speak the same language : we saw the inhabitants of Borneo, Celebes, Java, and Sumatra. In colour they resemble the Tahitians, from whom they do not widely differ in features. Some of the women, however, show a good deal of the Chinese character. I liked both their general expressions and the sound of their voices. They appeared poor, and their houses were destitute of furniture; but it was evident, from the plumpness of the little children, that cocoa-nuts and turtle afford no bad sustenance.

On this island the wells are situated from which ships obtain water. At first sight it appears not a little remarkable that the fresh water should regularly ebb and flow with the tides; and it has even been imagined that sand has the power of filtering the salt from the sea-water. These ebbing wells are common on some of the low islands in the West Indies. The compressed sand, or porous coral rock, is permeated like a sponge with the 
salt water; but the rain which falls on the surface must sink to the level of the surrounding sea, and must accumulate there, lisplacing an equal bulk of the salt water. As the water in the lower part of the great sponge-like coral mass rises and falls with the tides, so will the water near the surface; and this will keep fresh, if the mass be sufficiently compact to prevent much mechanical admixture; but where the land consists of great loose blocks of coral with open interstices, if a well be dug, the water, as I have seen, is brackish.

After dimner we stayed to see a curious halfsimerstitious scene acted by the Malay women. A large wooden spoon dressed in garments, and which had been carried to the grave of a dead man, they pretend becomes inspired at the full of the moon, and will dance and jump about. After the proper preparations, the spoon, held by two women, became convulsed, and danced in good time to the song of the surrounding children and women. It was a most foolish spectacle ; but Mr. Liesk maintained that many of the Malays believed in its spiritual movements. The dance did not commence till the moon had risen, and it was well worth remaining to behold her bright orb so quietly shining through the long arms of the cocoa-nut trees as they waved in the evening breeze. These scenes of the tropics are in themselves so delicious, that they almost equal those dearer ones at home, to which we are bound by each best feeling of the mind.

The next day I employed myself in examining the very interesting, yet simple structure and origin of these islands. The water being unusually smooth, I waded over the outer flat of dead rock as far as the living mounds of coral, on which the swell of the open sea breaks. In some of the gul- 
leys and hollows there were beautiful green and other coloured fishes, and the forms and tints of many of the zoophytes were admirable. It is excusable to grow enthusiastic over the infinite numbers of organic beings with which the sea of the tropics, so prodigal of life, teems; yet I must confess I think those naturalists who have described, in well-known words, the submarine grottoes decked with a thousand beauties, have indulged in rather exuberant language.

April 6th.-I accompanied Captain Fitz Roy to an island at the head of the lagoon: the channel was exceedingly intricate, winding through fields of delicately-branched corals. We saw several turtle, and two boats were then employed in catching them. The water was so clear and shallow, that although at first a turtle quickly dives out of sight, yet in a canoe or boat under sail, the pursuers, after no very long chase, come up to it. A man, standing ready in the bow, at this moment dashes through the water upon the turtle's back; then clinging with both hands by the shell of its neck, he is carried away till the animal becomes exhausted and is secured. It was quite an interesting chase to see the two boats thus doubling about, and the men dashing head foremost into the water trying to seize their prey. Captain Moresby informs me that in the Chagos Archipelago, in this same ocean, the natives, by a horrible process, take the shell from the back of the living turtle. "It is covered with burning charcoal, which causes the outer shell to curl upwards; it is then forced off with a knife, and, before it becomes cold, flattened between boards. After this barbarous process the animal is suffered to regain its native element, where, after a certain time, a new shell is form$\mathrm{ed}$; it is, however, too thin to be of any service, 
and the animal always appears languishing and sickly."

When we arrived at the head of the lagoon, we crossed a narrow islet, and found a great surf breaking on the windward coast. I can hardly explain the reason, but there is, to my mind, much grandeur in the view of the outer shores of these lagoon-islands. There is a simplicity in the barrier-like beach, the margin of green bushes and tall cocoa-nuts, the solid flat of dead coral-rock, strewed here and there with great loose fragments, and the line of furious breakers, all rounding away towards either hand. The ocean, throwing its waters over the broad reef, appears an invincible, all-powerful enemy; yet we see it resisted, and even conquered, by means which at first seem most weak and inefficient. It is not that the ocean spares the rock of coral; the great fragments scattered over the reef, and heaped on the beach, whence the tall cocoa-nut, springs, plainly bespeak the unrelenting power of the waves. Nor are any periods of repose granted. The long swell caused by the gentle but steady action of the trade-wind, always blowing in one direction over a wide area, causes breakers, almost equaling in force those during a gale of wind in the temperate regions, and which never cease to rage. It is impossible to behold these waves without feeling a conviction that an island, though built of the hardest rock, let it be porphyry, granite, or quartz, would ultimately yield, and be demolished by such an irresistible power. Yet these low, insignificant coral islets stand and are victorious; for here another power, as an antagonist, takes part in the contest. The organic forces separate the atoms of carbonate of lime, one by one, from the foaming breakers, and unite them into a symmetrical structure. Let the 
hurricane tear up its thousand huge fragments; yet what will that tell against the accumulated labour of myriads of architects at work night and day, month after month? Thus do we see the soft and gelatinous body of a polypus, through the agency of the vital laws, conquering the great mechanical power of the waves of an ocean which neither the art of man nor the inanimate works of nature could successfully resist.

We did not return on board till late in the evening, for we stayed a long time in the lagoon, examining the fields of coral and the gigantic shells of the chama, into which, if a man were to put his hand, he would not, as long as the animal lived, be able to withdraw it. Near the head of the lagoon, I was much surprised to find a wide area, considerably more than a mile square, covered with a forest of delicately branching corals, which, though standing upright, were all dead and rotten. At first I was quite at a loss to understand the cause; afterwards it occurred to me that it was owing to the following rather curious combination of circumstances. It should, however, first be stated, that corals are not able to survive even a short exposure in the air to the sun's rays, so that their upward limit of growth is determined by that of lowest water at spring tides. It appears, from some old charts, that the long island to windward was formerly separated by wide channels into sereral islets; this fact is likewise indicated by the trees being younger on these portions. Under the former condition of the reef, a strong breeze, by throwing more water over the barrier, would tend to raise the level of the lagoon. Now it acts in a directly contrary manner; for the water within the lagoon not only is not increased by currents from the outside, but is itself blown outwards by the IJ.- $\mathrm{I}^{2}$ 
force of the wind. Hence it is observed that the tide near the head of the lagoon does not rise so high during a strong breeze as it does when it is calm. This difference of level, although no doubt very small, has, I believe, cansed the death of those coral groves which, under the former and more open condition of the outer reef, had attained the utmost possible limit of upward growth.

A few miles north of Keeling there is another small atoll, the lagoon of which is nearly filled up with coral mud. Captain Ross found embedded in the conglomerate on the outer coast a wellrounded fragment of greenstone, rather larger than a man's head: he, and the men with him, were so much surprised at this, that they brought it away and preserved it as a curiosity. The occurrence of this one stone, where every other particle of matter is calcareous, certainly is very puzzling. The island has scarcely ever been visited, nor is it probable that a ship had been wrecked there. From the absence of any better explanation, I came to the conclusion that it must have come entangled in the roots of some large tree; when, however, I considered the great distance from the nearest land, the combination of chances against a stone thus being entangled, the tree washed into the sea, floated so far, then landed safely, and the stone, finally, so embedded as to allow of its discovery, I was almost afraid of imagining a means of transport apparently so improbable. It was therefore with great interest that I found Chamisso, the justly distinguished naturalist who accompanied Kotzebue, stating that the inhabitants of the Radack Archipelago, a group of lagoon-islands in the midst of the Pacific, obtained stones for sharpening their instruments by searching the roots of trees which are cast upon the beach. It will be evident that this 
must have happened several times, since laws have been established that such stones belong to the chief, and a punishment is inflicted on any one who attempts to steal them. When the isolated position of these small islands in the midst of a vast ocean-their great distance from any land excepting that of coral formation, attested by the value which the inhabitants, who are such bold navigators, attach to a stone of any kind, ${ }^{*}$ and the slowness of the currents of the open sea, are all considered, the occurrence of pebbles thus transported does appear wonderful. Stones may often be thus carried; and if the island on which they are stranded is constructed of any other substance besides coral, they would scarcely attract attention, and their origin, at least, would never be guessed. Moreover, this agency may long escape discovery, from the probability of trees, especially those loaded with stones, floating beneath the surface. In the channels of Tierra del Fuego large quantities of drift timber are cast upon the beach, yet it is extremely rare to meet a tree swimming on the water. These facts may possibly throw light on single stones, whether angular or rounded, occasionally found embedded in fine sedimentary masses.

During another day I visited West Islet, on which the vegetation was perhaps more luxuriant than on any other. The cocoa-nut trees generally grow separate, but here the young ones flourished beneath their tall parents, and formed, with their long and curved fronds, the most shady arbours. Those alone who have tried it know how delicious it is to be seated in such shade, and drink the cool, pleasant fluid of the cocoa-nut. In this island there

* Some natives carried by Kotzebue to Kamtschatka collected stones to take back to their country. 
is a large bay-like space, composed of the finest white sand: it is quite level, and is only covered by the tide at high water; from this large bay smaller creeks penetrate the surrounding woods. To see a field of glittering white sand, representing water, with the cocoa-nut trees extending their tall and waving trunks round the margin, formed a singular and very pretty view.

I have before alluded to a crab which lives on the cocoa-nuts: it is very common on all parts of the dry land, and grows to a monstrous size : it is closely allied or identical with the Birgos latro. The front pair of legs terminate in very strong and heavy pincers, and the last pair are fitted with others weaker and much narrower. It would, at first, be thought quite impossible for a crab to open a strong cocoa-nut covered with the husk; but Mr. Liesk assures me that he has repeatedly seen this effected. The crab begins by tearing the husk, fibre by fibre, and always from that end under which the three eye-holes are situated; when this is completed, the crab commences hammering with its heavy claws on one of the eye-holes till an opening is made. Then turning round its body, by the aid of its posterior and narrow pair of pincers it extracts the white albuminous substance. I think this is as curious a case of instinct as ever I heard of, and likewise of adaptation in structure between two objects apparently so remote from each other in the scheme of nature as a crab and a cocoa-nut tree. The Birgos is diurnal in its habits; but every night it is said to pay a visit to the sea, no doubt for the purpose of moistening its branchiæ. The young are likewise hatched, and live for some time, on the coast. These crabs inhabit deep burrows, which they hollow out beneath the roots of trees, and where they accumulate sur- 
prising quantities of the picked fibres of the cocoanut husk, on which they rest as on a bed. The Malays sometimes take advantage of this, and collect the fibrous mass to use as junk. These crabs are very good to eat; moreover, under the tail of the larger ones there is a great mass of fat, which, when melted, sometimes yields as much as a quart bottle full of limpid oil. It has been stated by some authors that the Birgos crawls up the cocoanut trees for the purpose of stealing the nuts: I very much doubt the possibility of this; but with the Pandanus* the task would be very much easier. I was told by Mr. Liesk that on these islands the Birgos lives only on the nuts which have fallen to the ground.

Captain Moresby informs me that this crab inhabits the Chagos and Seychelle groups, but not the neighbouring Maldiva Archipelago. It formerly abounded at Mauritius, but only a few small ones are now found there. In the Pacific, this species, or one with closely-allied habits, is said $\dagger$ to inhabit a single coral island north of the Society group. To show the wonderful strength of the front pair of pincers, I may mention that Captain Moresby confined one in a strong tin box, which had held biscuits, the lid being secured with wire; but the crab turned down the edges and escaped. In turning down the edges, it actually punched many small holes quite through the tin!

I was a good deal surprised by finding two species of coral, of the genus Millepora (M. complanata and alcicornis), possessed of the power of stinging. The stony branches or plates, when taken fresh from the water, have a harsh feel and are not slimy, although possessing a strong and

* See Proceedings of Zoological Society, 1832, p. 17. † Tyerman and Bennett. Voyage, \&c., vol. ii., p. 33.

II. 
disagreeable smell. The stinging property seems to vary in different specimens. When a piece was pressed or rubbed on the tender skin of the face or arm, a pricking sensation was usually caused, which came on after the interval of a second, and lasted only for a few minutes. One day, however, by merely touching my face with one of the branches, pain was instantaneously caused; it increased, as usual, after a few seconds, and remaining sharp for some minutes, was perceptible for half an hour afterwards. The sensation was as bad as that from a nettle, but more like that caused by the Physalia, or Portuguese man-of-war. Little red spots were produced on the tender skin of the arm, which appeared as if they would have formed watery pustules, but did not. MI. Quoy mentions this case of the Millepora, and I have heard of stinging corals in the West Indies. Many marine animals seem to have this power of stinging: besides the Portuguese man-of-war, many jelly-fish, and the Aplysia, or" sea-slug of the Cape de Verd Islands, it is stated in the royage of the Astrolabe that an Actinia, or sea-anemone, as well as a flexible coralline allied to Sertularia, both possess this means of offence or defence. In the East Indian sea a stinging sea-weed is said to be found.

Two species of fish, of the genus Scarus, which are common here, exclusively feed on coral : both are coloured of a splendid bluish-green, one living invariably in the lagoon, and the other amongst the outer breakers. Mr. Liesk assured us that he had repeatedly seen whole shoals grazing with their strong bony jaws on the tops of the coral branches. I opened the intestines of several, and found them distended with yellowish, calcareous, sandy mud. The slimy, disgusting Holuthuriæ (allied to our star-fish), which the Chinese gourmands are so 
fond of, also feed largely, as I am informed by Dr. Allan, on corals; and the bony apparatus within their bodies seems well adapted for this end. These holuthuriæ, the fish, the numerous burrowing shells and nereidous worms which perforate every block of dead coral, must be very efficient agents in producing the fine white mud which lies at the bottom and on the shores of the lagoon. A portion, however, of this mud, which, when wet, strikingly resembled pounded chalk, was found by Professor Ehrenberg to be partly composed of siliceous-shielded infusoria.

April 12th.-In the morning we stood out of the lagoon on our passage to the Isle of France. I am glad we have visited these islands: such formations surely rank high amongst the wonderful objects of this world. Captain Fitz Roy found no bottom with a line 7200 feet in length, at the distance of only 2200 yards from the shore; hence this island forms a lofty sub-marine mountain, with sides steeper even than those of the most abrupt volcanic cone. The saucer-shaped summit is nearly ten miles across; and every single atom, ${ }^{*}$ from the least particle to the largest fragment of rock, in this great pile, which, however, is small compared with very many other lagoon-islands, bears the stamp of having been subjected to organic arrangement. We feel surprise when travellers tell us of the vast dimensions of the Pyramids and other great ruins, but how utterly insignificant are the greatest of these when compared to these mountains of stone, accumulated by the agency of various minute and tender animals! This is a wonder

* I exclude, of course, some soil which has been imported here in vessels from Malacca and Java, and likewise some small fragments of pumice, drifted here by the waves. The one block of greenstone, moreover, on the northern island, must be ex cepted. 
which does not at first strike the eye of the body, but, after reflection, the eye of reason.

I will now give a very brief account of the three great classes of coral-reefs, namely, Atolls, Barrier, and Fringing reefs, and will explain my views* on their formation. Almost every voyager who has crossed the Pacific has expressed his unbounded astonishment at the lagoon-islands, or atolls, as I shall for the future call them by their Indian name, and has attempted some explanation. Even as long ago as the year 1605, Pyrard de Laval well exclaimed, "C'est une meruille de voir chacun de ces atollons, enuironné d'un grand banc de pierre tout autour, n'y ayant point d'artifice humain." The accompanying sketch of Whitsunday Island in the Pacific, copied from Captain Beechey's admirable Voyage, gives but a faint idea of the singular aspect of an atoll : it is one of the

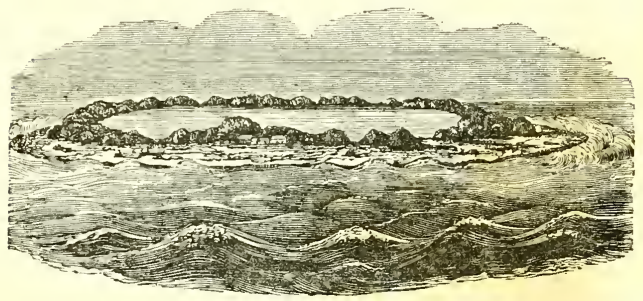

smallest size, and has its narrow islets united together in a ring. The immensity of the ocean, the fury of the breakers, contrasted with the lowness

* These were first read before the Geological Society in May, 1837 , and have since been developed in a separate volume on the "Structure and Distribution of Coral Reefs." 
of the land and the smoothness of the bright green water within the lagoon, can hardly be imagined without having been seen.

The earlier voyagers fancied that the coralbuilding animals instinctively built up their great circles to afford themselves protection in the inner parts; but so far is this from the truth, that those massive kinds, to whose growth on the exposed outer shores the very existence of the reef depends, cannot live within the lagoon, where other delicately-branching kinds flourish. Moreover, on this view, many species of distinct genera and families are supposed to combine for one end, and of such a combination not a single instance can be found in the whole of nature. The theory that has been most generally received is, that atolls are based on submarine craters; but when we consider the form and size of some, the number, proximity, and relative positions of others, this idea loses its plausible character: thus, Suadiva atoll is 44 geographical miles in diameter in one line, by 34 miles in another line; Rimsky is 54 by 20 miles across, and it has a strangely sinuous margin; Bow atoll is 30 miles long, and, on an average, only six in width; Menchicoff atoll consists of three atolls united or tied together. This theory, moreover, is totally inapplicable to the northern Maldiva atolls in the Indian Ocean (one of which is 88 miles in length, and between 10 and 20 in breadth), for they are not bounded, like ordinary atolls, by narrow reefs, but by a vast number of separate little atolls; other little atolls rising out of the great central lagoon-like spaces. A third and better theory was advanced by Chamisso, who thought that, from the corals growing more vigorously where exposed to the open sea, as undoubtedly is the case, the outer edges would grow up from the 
general foundation before any other part, and that this would account for the ring or cup-shaped structure; but we shall immediately see that in this, as well as in the crater-theory, a most important consideration has been overlooked, namely, on what lave the reef-building corals, which cannot live at a great depth, based their massive structures?

Numerous soundings were carefully taken by Captain Fitz Roy on the steep outside of Keeling atoll, and it was found that within ten fathoms the prepared tallow at the bottom of the lead invariably came up marked with the impressions of living corals, but as perfectly clean as if it had been dropped on a carpet of turf; as the depth increased, the impressions became less numerous, but the adhering particles of sand more and more numerous, until, at last, it was evident that the bottom consisted of a smooth sandy layer: to carry on the analogy of the turf, the blades of grass grew thinner and thinner, till at last the soil was so sterile that nothing sprang from it. From these observations, confirmed by many others, it may be safely inferred that the utmost depth at which corals can construct reefs is between 20 and 30 fathoms. Now there are enormous areas in the Pacific and Indian Oceans, in which every single island is of coral formation, and is raised ouly to that height to which the waves can throw up fragments and the winds pile up sand. Thus the Radack group of atolls is an irregular square, 520 miles long and 240 broad; the Low Archipelago is elliptic-formed, 840 miles in its longer, and 420 in its shorter axis: there are other small groups and single low islands between these two archipelagoes, making a linear space of ocean actually more than 4000 miles in length, in which not one single island rises above 
the specified height. Again, in the Indian Ocean, there is a space of ocean 1500 miles in length, including three archipelagoes, in which every island is low and of coral formation. From the fact of the reef-building corals not living at great depths, it is absolutely certain that throughout these vast areas, wherever there is now an atoll, a foundation must have originally existed within a depth of from 20 to 30 fathoms from the surface. It is improbable in the highest degree that broad, lofty, isolated, steep-sided banks of sediment, arranged in groups and lines hundreds of leagues in length, could have been deposited in the central and profoundest parts of the Pacific and Indian Oceans, at an immense distance from any continent, and where the water is perfectly limpid. It is equally improbable that the elevatory forces should have uplifted, throughout the above vast areas, innumerable great rocky banks within 20 to 30 fathoms, or 120 to 180 feet, of the surface of the sea, and not one single point above that level; for where, on the whole face of the globe, can we find a single chain of mountains, even a few hundred miles in length, with their many summits rising within a few feet of a given level, and not one pinnacle above it? If, then, the foundations, whence the atoll-building corals sprang, were not formed of sediment, and if they were not lifted up to the required level, they must, of necessity, have subsided into it, and this at once solves the difficulty; for as mountain after mountain, and island after island, slowly sank beneath the water, fresh bases would be successively afforded for the growth of the corals. It is impossible here to enter into all the necessary details, but I venture to defy* any one to explain in any other man-

* It is remarkable that Mr. Lyell, even in the first edition of his "Principles of Geology," inferred that the amount of subsidence 
ner how it is possible that numerous islands should be distributed throughout vast areas-all the islands being low-all being built of corals, absolutely requiring a foundation within a limited depth from the surface.

Before explaining how atoll-formed reefs acquire their peculiar structure, we must turn to the second great class, namely, Barrier-reefs. These either extend in straight lines in front of the shores of a continent or of a large island, or they encircle smaller islands; in both cases being separated from the land by a broad and rather deep channel of water, analogous to the lagoon within an atoll. It is remarkable how little attention has been paid to encircling barrier-reefs, yet they are truly wonderful structures. The following sketch represents part of the barrier encircling the island of Bolabola in the Pacific, as seen from one of the central peaks.

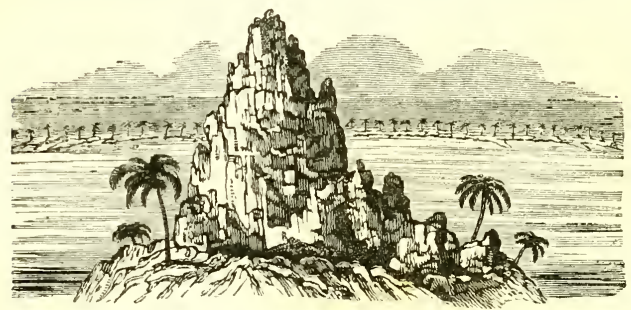

In this instance the whole line of reef has been converted into land; but usually a snow-white line of great breakers, with only here and there a single low islet, crowned with cocoa-nut trees, divides the

in the Pacific must have exceeded that of elevation, from the area of land being very small relatively to the agents there tending to form it, namely, the growth of coral and volcanic action. 
dark, heaving waters of the ocean from the lightgreen expanse of the Jagoon-channel. And the quiet waters of this channel generally bathe a fringe of low alluvial soil, loaded with the most beautiful productions of the tropics, and lying at the foot of the wild, abrupt, central mountains.

Encircling barrier-reefs are of all sizes, from three miles to no less than forty-four miles in diameter; and that, which fronts one side, and encircles both ends of New Caledonia, is 400 miles long. Each reef includes one, two, or several rocky islands of various heights; and, in one instance, even as many as twelve separate islands. The reef runs at a greater or less distance from the included land; in the Society Archipelago, generally from one to three or four miles; but at Hogoleu the reef is 20 miles on the southern side, and 14 miles on the opposite or northern side, from the included islands. The depth within the lagoon-channel also varies much; from 10 to 30 fathoms may be taken as an average; but at Vanikoro there are spaces no less than 56 fathoms, or 336 feet deep. Internally the reef either slopes gently into the lagoonchannel, or ends in a perpendicular wall sometimes between two and three hundred feet under water in height: externally, the reef rises, like an atoll, with extreme abruptness out of the profound depths of the ocean. What can be more singular than these structures? We see an island, which may be compared to a castle situated on the summit of a lofty submarine mountain, protected by a great wall of coral-rock, always steep externally and sometimes internally, with a broad level summit, here and there breached by narrow gateways, through which the largest ships can enter the wide and deep encircling moat.

As far as the actual reef of coral is concerned, II. - Z 
there is not the smallest difference in general size, outline, grouping, and even in quite trifling details of structure between a barrier and an atoll. The geographer Balbi has well remarked, that an encircled island is an atoll with high land rising out of its lagoon; remove the land from within, and a perfect atoll is left.

But what has caused these reefs to spring up at such great distances from the shores of the included islands? It cannot be that the corals will not grow close to the land, for the shores within the lagoon-channel, when not surrounded by alluvial soil, are often fringed by living reefs; and we shall presently see that there is a whole class, which I have called Fringing Reefs, from their close attachment to the shores both of continents and of islands. Again, on what have the reef-building corals, which cannot live at great depths, based their encircling structures? This is a great apparent difficulty, analogous to that in the case of atolls, which has generally been overlonked. It will be perceived more clearly by inspecting the following sections,

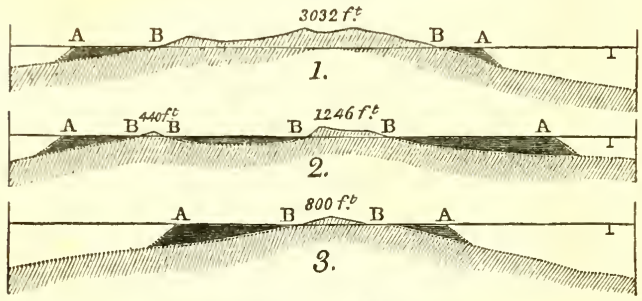

1. Vanikoro. 2. Gambier Islands, 3. Maurua.

The horizontal shading shows the barrier-reefs and lagoon-channels. The inclined shading above the level of the sea (A A) shows the actual form of the land; the inclined shading below this line shows its probable prolongation under water. 
which are real ones, taken in north and south lines through the islands, with their barrier-reefs, of Vanikoro, Gambier, and Maurua; and they are laid down, both vertically and horizontally, on the scale of three sixteenths of an inch to a mile.

It should be observed that the sections might have been taken in any direction through these islands, or through many other encircled islands, and the general features would have been the same. Now, bearing in mind that reef-building coral cannot live at a greater depth than from 20 to 30 fathoms, and that the scale is so small that the plummets on the right hand show a depth of 200 fathoms, on what are these barrier-reefs based ? Are we to suppose that each island is surrounded by a collar-like submarine ledge of rock, or by a great bank of sediment, ending abruptly where the reef ends? If the sea had formerly eaten deeply into the islands, before they were protected by the reefs, thus having left a shallow ledge round them under water, the present shores would have been invariably bounded by great precipices; but this is most rarely the case. Moreover, on this notion, it is not possible to explain why the corals should have sprung up, like a wall, from the extreme outer margin of the ledge, often leaving a broad space of water within too deep for the growth of corals. The accumulation of a wide bank of sediment all round these islands, and generally widest where the included islands are smallest, is highly improbable, considering their exposed positions in the central and deepest parts of the ocean. In the case of the barrier-reef of New Caledonia, which extends for 150 miles beyond the northem point of the island, in the same straight line with which it fronts the west coast, it is hardly possible to believe that a bank of sediment could thus have 
been straightly deposited in front of a lofty island, and so far beyond its termination in the open sea. Finally, if we look to other oceanic islands of about the same height and of similar geological constitution, but not encircled by coral-reefs, we may in vain search for so trifling a circumambient depth as 30 fathoms, except quite near to their shores; for usually land that rises abruptly out of water, as do most of the encircled and non-encircled oceanic islands, plunges abruptly under it. On what, then, I repeat, are these barrier-reefs based? Why, with their wide and deep moatlike channels, do they stand so far from the included land? We shall soon see how easily these difficulties disappear.

We come now to our third class of Fringing Reefs, which will require a very short notice. Where the land slopes abruptly under water, these reefs are only a few yards in width, forming a mere riband or fringe round the shores: where the land slopes gently under the water, the reef extends further, sometimes even as much as a mile from the land; but in such cases the soundings outside the reef always show that the submarine prolongation of the land is gently inclined. In fact, the reefs extend only to that distance from the shore at which a foundation within the requisite depth from 20 to 30 fathoms is found. As far as the actual reef is concerned, there is no essential difference between it and that forming a barrier or an atoll : it is, however, generally of less width, and consequently few islets have been formed on it. From the corals growing more vigorously on the outside, and from the noxious effect of the sediment washed inwards, the outer edge of the reef is the highest part, and between it and the land there is generally a shallow sandy channel a few 
feet in depth. Where banks of sediment have accumulated near to the surface, as in parts of the West Indies, they sometimes become fringed with corals, and hence, in some degree, resemble lagoonislands or atolls; in the same manner as fringingreefs, surrounding gently-sloping islands, in some degree resemble barrier-reefs.

No theory on the formation of coral-reefs can be considered satisfactory which does not include the three great classes. We have seen that we are driven to believe in the subsidence of those vast areas, interspersed with low islands, of which not one rises above the height to which the wind and waves can throw up matter, and yet are constructed by animals requiring a foundation, and that foundation to lie at no great depth. Let us, then, take an island surrounded by fringing-reefs, which offer no difficulty in their structure; and let this island with its reef, represented by the unbroken lines in the woodcut, slowly subside. Now, as the island, sinks down, either a few feet at a time or quite insensibly, we may safely infer, from what is known

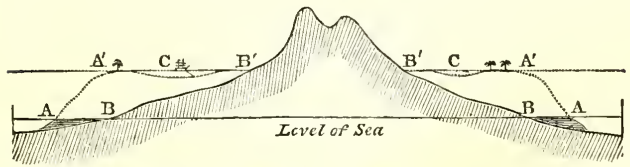

A A. Outer edges of the fringing-reef, at the level of the sea. B B. The shores of the fringed island.

$\mathrm{A}^{\prime} \mathrm{A}^{\prime}$. Outer edges of the reef, after its upward growth during a period of subsidence, now converted into a barrier, with islets on it. $\mathbf{B}^{\prime} \mathrm{B}^{\prime}$. The shores of the now encircled island. C C. Lagoon-channel.

N.B. In this and the following woodcut, the subsidence of the land could be represented only by an apparent rise in the level of the sea.

of the conditions favourable to the growth of coral, that the living masses, bathed by the surf on the 
margin of the reef, will soon regain the surfaces. The water, however, will encroach little by litue on the shore, the island becoming lower and smaller, and the space between the inner edge of the reef and the beach proportionally broader. A section of the reef and island in this state, after a subsidence of several hundred feet, is given by the dotted lines. Coral islets are supposed to have been formed on the reef; and a ship is anchored in the lagoon-chamel. This channel will be more or less deep, according to the rate of subsidence, to the amount of sediment accumulated in it, and to the growth of the delicately branched corals which can live there. The section in this state resembles in every respect one drawn through an encircled island: in fact, it is a real section (on the scale of 388 of an inch to a mile) through Bolabola in the Pacific. We can now at once see why encircling barrier-reefs stand so far from the shores which they front. We can also perceive that a line drawn perpendicularly down from the outer edge of the new reef to the foundation of solid rock beneath the old fringing-reef, will exceed by as many feet as there have been feet of subsidence that small limit of depth at which the effective corals can live; the little architects having built up their great wall-like mass, as the whole sank down, upon a basis formed of other corals and their consolidated fragments. Thus the difficulty on this head, which appeared so great, disappears.

If, instead of an island, we had taken the shore of a continent fringed with reefs, and had imagined it to have subsided, a great straight barrier, like that of Australia or New Caledonia, separated from the land by a wide and deep channel, would evidently have been the result.

Let us take our new encircling barrier-reef, of 
which the section is now represented by unbroken lines, and which, as I have said, is a real section through Bolabola, and let it go on subsiding. As the barrier-reef slowly sinks down, the corals will

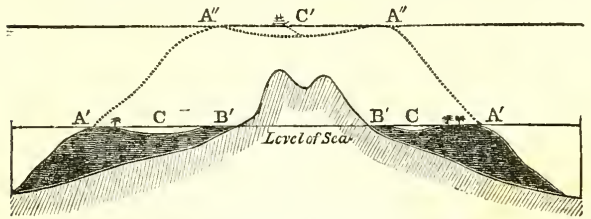

$\mathrm{A}^{\prime} \mathrm{A}^{\prime}$. Outer edges of the barrier-reef at the level of the sea, with islets on it. B'B'. The shores of the included island. C C. The lagoon-channel.

$\mathrm{A}^{\prime \prime} \mathrm{A}^{\prime \prime}$. Outer edges of the reef, now converted into an atoll. C'. The lagoon of the new atoll.

N.B. According to the true scale, the depths of the lagoon-channel and lagoon are much exaggerated.

go on vigorously growing upwards; but as the island sinks, the water will gain inch by inch on the shore, the separate mountains first forming separate islands within one great reef, and, finally, the last and highest pinnacle disappearing. The instant this takes place a perfect atoll is formed: I have said, remove the high land from within an encircling barrier-reef, and an atoll is left, and the land has been removed. We can now perceive how it comes that atolls, having sprung from encircling barrier-reefs, resemble them in general size, form, in the manner in which they are grouped together, and in their arrangement in single or double lines; for they may be called rude outline charts of the sunken islands over which they stand. We can further see how it arises that the atolls in the Pacific and Indian Oceans extend in lines parallel to the generally prevailing strike of the high islands and great coast-lines of those oceans. I venture, therefore, to affirm, that on the theory 
of the upward growth of the corals during the sinking of the land,* all the leading features in those wonderful structures, the lagoon islands or atolls, which have so long excited the attention of voyagers, as well as in the no less wonderful barrierreefs, whether encircling small islands or stretching for hundreds of miles along the shores of a continent, are simply explained.

It may be asked whether I can offer any direct evidence of the subsidence of barrier-reefs or atolls; but it must be borne in mind how difficult it must ever be to detect a movement the tendency of which is to hide under water the part affected. Nevertheless, at Keeling atoll I observed on all sides of the lagoon old cocoa-nut trees undermined and falling; and in one place the foundation-posts of a shed, which the inhabitants asserted had stood seven years before just above high-water mark, but now was daily washed by every tide: on inquiry, I found that three earthiquakes, one of them severe, had been felt here during the last ten years. At Vanikoro, the lagoon-channel is remarkably deep, scarcely any alluvial soil has accumulated at the foot of the lofty included mountains, and remarkably few islets have been formed by the heaping of fragments and sand on the wall-like barrierreef; these facts, and some analogous ones, led me to believe that this island must lately have subsided and the reef grown upwards: here, again, earthquakes are frequent and very severe. In the

* It has been highly satisfactory to me to find the following passage in a pamphlet by Mr. Couthouy, one of the naturalists in the great Antarctic Expedition of the United States: "Having personally examined a large number of coral-islands, and resided eight months among the volcanic class having shore and partially encircling reefs, I may be permitted to state that my own observations have impressed a conviction of the correctness of the theory of Mr. Darwin." The naturalists, however, of this expedition differ with me on some points respecting coral formations. 
Society Archipelago, on the other hand, where the lagoon channels are almost choked up, where much low alluvial land has accumulated, and where, in some cases, long islets have been formed on the barrier-reefs-facts all showing that the islands have not very lately subsided-only feeble shocks are most rarely felt. In these coral formations, whore the land and water seem struggling for mastery, it must be ever difficult to decide between the effects of a change in the set of the tides and of a slight subsidence: that many of these reefs and atolls are subject to changes of some kind is certain; on some atolls the islets appear to have increased greatly within a late period; on others they have been partially or wholly washed away. The inhabitants of parts of the Maldiva Archipelago know the date of the first formation of some islets; in other parts, the corals are now flourishing on water-washed reefs, where holes made for graves attest the former existence of inhabited land. It is difficult to believe in frequent changes in the tidal currents of an open ocean; whereas we have, in the earthquakes recorded by the natives on some atolls, and in the great fissures observed on other atolls, plain evidence of changes and disturbances in progress in the subterranean regions.

It is evident, on our theory, that coasts merely fringed by reefs cannot bave subsided to any perceptible amount; and therefore they must, since the growtl of their corals, either have remained stationary or have been upheaved. Now it is remarkable how generally it can be shown, by the presence of upraised organic remains, that the fringed islands have been elevated; and so far, this is indirect evidence in farour of our theory. I was particularly struck with this fact, when I found, to my surprise, that the descriptions given II, 
by MM. Quoy and Gaimard were applicable, not to reefs in general, as implied by them, but only to those of the fringing-class; my surprise, however, ceased when I afterwards found that, by a strange chance, all the several islands visited by these eminent naturalists could be shown, by their own statements, to have been elevated within a recent geological era.

Not only the grand featmes in the structure of barrier-reefs and of atolls, and of their likeness to each other in form, size, and other characters, are explained on the theory of subsidence-which theory we are independently forced to admit in the very areas in question, from the necessity of finding bases for the corals within the requisite depth-but many details in structure and exceptional cases can thus also be simply explained. I will give only a few instances. In barrier-reefs it has long been remarked with surprise, that the passages through the reef exactly face valleys in the included land, even in cases where the reef is separated from the land by a lagoon-channel so wide and so much deeper than the actual passage itself, that it seems hardly possible that the very small quantity of water or sediment bronght down could injure the corals on the reef. Now, every reef of the fringing-class is breached by a narrow gateway in front of the smallest rivulet, even if dry during the greater part of the year, for the mud, sand, or gravel, occasionally washed down, kills the corals on whicl it is deposited. Consequently, when an island thus fringed subsides, though most of the narrow gateways will probably become closed by the outward and upward growth of the corals, yet any that are not closed (and some must always be kept open by the sediment and impure water flowing out of the lagoon-channel) will still con- 
tinue to front exactly the upper part of those valleys, at the mouths of which the original basal fringing-reef was breached.

We can easily see how an island fronted only on one side, or on one side with one end or both ends encircled by barrier-reefs, might, after longcontinued subsidence, be converted either into a single wall-like reef, or into an atoll with a great straight spur projecting from it, or into two or three atolls tied together by straight reefs-all of which exceptional cases actually occur. As the reef-building corals require food, are preyed upon by other animals, are killed by sediment, cannot adhere to a loose bottom, and may be easily carried down to a depth whence they cannot spring up again, we need feel no surprise at the reefs both of atolls and barriers becoming in parts imperfect. The great barrier of New Caledonia is thus imperfect and broken in many parts; hence, after long subsidence, this great reef would not produce one great atoll 400 miles in length, but a chain or archipelago of atolls, of very nearly the same dimensions with those in the Maldiva Archipelago. Moreover, in an atoll once breached on opposite sides, from the likelihood of the oceanic and tidal currents passing straight through the breaches, it is extremely improbable that the corals, especially during continued subsidence, would ever be able again to unite the rim; if they did not, as the whole sank downwards, one atoll would be divided into two or more. In the Maldiva Archipelago there are distinct atolls so related to each other in position, and separated by channels either unfathomable or very deep (the channel between Ross and Ari atolls is 150 fathoms, and that between the north and south Nillandoo atolls is 200 fathoms in depth), that it is impossible to look at 
a map of them without believing that they were once more intimately related; and in this same archipelago, Mahlos-Mahdoo atoll is divided by a bifurcating channel, from 100 to 132 fathoms in depth, in such a manner that it is scarcely possible to say whether it ought strictly to be called three separate atolls, or one great atoll not yet finally divided.

I will not enter on many more details; but I must remark that the curious structure of the northern Maldiva atolls receives (taking into consideration the free entrance of the sea through their broken margins) a simple explanation in the upward and outward growth of the corals, originally based both on small detached reefs in their lagoons, such as occur in common atolls, and on broken portions of the linear marginal reef, such as bounds every atoll of the ordinary form. I cannot refrain from once again remarking on the singularity of these complex structures-a great sandy and generally concave disk rises abruptly from the unfathomable ocean, with its central expanse studded, and its edge symmetrically bordered with oval basins of coral-rock just lipping the surface of the sea, sometimes clothed with vegetation, and each containing a lake of clear water!

One more point in detail: as in two neighbouring archipelagoes corals flourish in one and not in the other, and as so many conditions before enumerated must affect their existence, it would be an inexplicable fact if, during the changes to which earth, air, and water are subjected, the reef-building corals were to keep alive for perpetuity on any one spot or area. And as by our theory the areas including atolls and barrier-reefs are subsiding, we ought occasionally to find reefs both dead and submerged. In all reefs, owing to the sediment being 
washed out of the lagoon or lagoon-channel to leeward, that side is least favourable to the long-continued vigorous growth of the corals; hence dead portions of reef not unfrequently occur on the leeward side; and these, though still retaining their proper wall-like form, are now, in several instances, sunk several fathoms beneath the surface. The Chagos group appears from some cause, possibly from the subsidence having been too rapid, at present to be much less favourably circumstanced for the growth of reefs than formerly: one atoll has a portion of its marginal reef, nine miles in length, dead and submerged; a second has only a few quite small living points which rise to the surface; a third and fourth are entirely dead and submerged; a fifth is a mere wreck, with its structure almost obliterated. It is remarkable that in all these cases the dead reefs and portions of reef lie at nearly the same depth, namely, from six to eight fathoms beneath the surface, as if they had been carried down by one uniform movement. One of these " half-drowned atolls," so called by Captain Moresby (to whom I am indebted for much invaluable information), is of vast size, namely, ninety nautical miles across in one direction, and seventy miles in another line, and is in many respects eminently curious. As by our theory it follows that new atolls will generally be formed in each new area of subsidence, two weighty objections might have been raised, namely, that atolls must be increasing indefinitely in number; and, secondly, that in old areas of subsidence each separate atoll must be increasing indefinitely in thickness, if proofs of their occasional destruction could not have been adduced. Thus have we traced the history of these great rings of coral rock, from their first origin through their normal changes, and II.-A A 
through the occasional accidents of their existence, to their death and final obliteration.

In my volume on "Coral Formations" I have published a map, in which $I$ have coloured all the atolls dark-blue, the barrier-reefs pale-blue, and the fringing-reefs red. These latter reefs have been formed whilst the land has been stationary, or, as appears from the frequent presence of up raised organic remains, whilst it has been slowly rising: atolls and barrier-reefs, on the other hand, have grown up during the directly opposite movement of subsidence, which movement must have been very gradual, and in the case of atolls so vast in amount as to have buried every mountain-summit over wide ocean-spaces. Now in this map we see that the reefs tinted pale and dark blue, which have been produced by the same order of movement, as a general rule, manifestly stand near each vther. Again, we see that the areas with the two blue tints are of wide extent, and that they lie separate from extensive lines of coast coloured red, both of which circumstances might naturally have been inferred, on the theory of the nature of the reefs having been governed by the nature of the earth's movement. It deserves notice, that in more than one instance where single red and blue circles approach near each other, I can show that there have been oscillations of level; for, in such cases, the red or fringed circles consist of atolls, originally, by our theory, formed during subsidence, but subsequently upheaved; and, on the other hand, some of the pale-blue or encircled islands are composed of coral-rock, which must have been uplifted to its present height before that subsidence took place, during which the existing barrier-reefs grew upwards. 
Authors have noticed with surprise that although atolls are the commonest coral-structures throughout some enormous oceanic tracts, they are entirely absent in other seas, as in the West Indies: we can now at once perceive the cause, for where there has not been subsidence, atolls cannot have been formed; and in the case of the West Indies and parts of the East Indies, these tracts are known to have been rising within the recent period. The larger areas, coloured red and blue, are all elongated; and between the two colours there is a degree of rude alternation, as if the rising of one had balanced the sinking of the other. Taking into consideration the proofs of recent elevation, both on the fringed coasts and on some others (for instance, in South America) where there are no reefs, we are led to conclude that the great continents are, for the most part, rising areas; and from the nature of the coral-reefs, that the central parts of the great oceans are sinking areas. The East Indian Archipelago, the most broken land in the world, is, in most parts, an area of elevation, but surrounded and penetrated, probably in more lines than one, by narrow areas of subsidence.

I have marked with vermilion spots all the many known active volcanoes within the limits of this same map. Their entire absence from every one of the great subsiding areas, coloured either pale or dark blue, is most striking; and not less so is the coincidence of the chief volcanic chains with the parts coloured red, which, we are led to conclude, have either long remained stationary, or more generally have been recently upraised. Although a few of the vermilion spots occur within no great distance of single circles tinted blue, yet not one single active volcano is situated within sereral hundred miles of an archipelago, or even small groups 
of atolls. It is, therefore, a striking fact, that in the Friendly Archipelago, which consists of a group of atolls upheaved and since partially worn down, two volcanoes, and perhaps more, are historically known to have been in action. On the other hand, although most of the islands in the Pacific which are encircled by barrier-reefs are of volcanic origin, often with the remnants of craters still distinguishable, not one of them is known to have ever been in eruption. Hence, in these cases, it would appear that volcanoes burst forth into action and become extinguished on the same spots accordingly as elevatory or subsiding movements prevail there. Numberless facts could be adduced to prove that upraised organic remains are common wherever there are active volcanoes; but until it could be shown that in areas of subsidence volcanoes were either absent or inactive, the inference, however probable in itself, that their distribution depended on the rising or falling of the earth's surface, would have been hazardous. But now, I think, we may freely admit this important deduction.

Taking a final view of the map, and bearing in mind the statements made with respect to the upraised organic remains, we must feel astonished at the vastness of the areas which have suffered changes in level either downwards or upwards, within a period not geologically remote. It would appear, also, that the elevatory and subsiding movements follow nearly the same laws. Throughout the spaces interspersed with atolls, where not a single peak of high land has been left above the level of the sea, the sinking must have been immense in amount. The sinking, moreover, whether continuous, or recurrent with intervals sufficiently long for the corals again to bring up their living edifices to the surface, must necessarily have been extreme- 
ly slow. This conclusion is probably the most important one which can be deduced from the study of coral formations, and it is one which it is difficult to imagine how otherwise could ever have been arrived at. Nor can I quite pass over the probability of the former existence of large archipelagoes of lofty islands, where now only rings of coral-rock scarcely break the open expanse of the sea, throwing some light on the distribution of the inhabitants of the other high islands, now left standing so immensely remote from each other in the midst of the great oceans. The reef-constructing corals have indeed reared and preserved wonderful memorials of the subterranean oscillations of level; we see in each barrier-reef a proof that the land has there subsided, and in each atoll a monument over an island now lost. We may thus, like unto a geologist who had lived his ten thousand years and kept a record of the passing changes, gain some insight into the great system by which the surface of this globe has been broken up, and land and water interchanged.

\section{CHAPTER IX.}

Mauritius, beautiful Appearance of-Great crateriform Ring of Mountains-Hindoos-St. Helena-History of the Changes in the Vegetation-Cause of the Extinction of Land-shells-Ascension-Variation in the imported Rats-Volcanic BombsBeds of Infusoria-Bahia-Brazil-Splendour of tropical Scenery-Pernambuco-Singular Reef-Slavery-Return to England-Retrospect on our Voyage.

MAURITIUS TO ENGLAND.

April 29th.-IN the morning we passed round the northern end of Mauritius, or the Isle of France. From this point of view the aspect of the island equalled the expectations raised by the A 2 
many well-known descriptions of its beautiful scenery. The sloping plain of the Pamplemonsses, interspersed with houses, and coloured by the large fields of sugar-cane of a bright green, composed the foreground. The brilliancy of the green was the more remarkable, because it is a colour which generally is conspicuous only from a very short distance. Towards the centre of the island groups of wooded mountains rose out of this highly-cultivated plain; their summits, as so commonly happens with ancient volcanic rocks, being jagged into the sharpest points. Masses of white clouds were collected around these pinnacles, as if for the sake of pleasing the stranger's eye. The whole island, with its sloping border and central mountains, was adorned with an air of perfect elegance; the scenery, if I may use such an expression, appeared to the sight harmonious.

I spent the greater part of the next day in walking about the town and visiting different people. The town is of considerable size, and is said to contain 20,000 inhabitants; the streets are very clean and regular. Although the island has been so many years under the English government, the general character of the place is quite French: Englishmen speak to their servants in French, and the shops are all French; indeed, I should think that Calais or Boulogne was much more Anglified. There is a very pretty little theatre, in which operas are excellently performed. We were also surprised at seeing large booksellers' shops, with well-stored shelves. Music and reading bespeak our approach to the old world of civilization; for in truth, both Australia and America are new worlds.

The various races of men walking in the streets afford the most interesting spectacle in Port Louis. 
Convicts from India are banished here for life; at present there are about 800 , and they are employed in various public works. Before seeing these people, I had no idea that the inhabitants of India were such noble-looking figures. Their skin is extremely dark, and many of the older men had large mustaches and beards of a snow-white colour ; this, together with the fire of their expression, gave them quite an imposing aspect. The greater number had been banished for murder and the worst crimes; others for causes which can scarcely be considered as moral faults, such as for not obeying, from superstitious motives, the English laws. These men are generally quiet and wellconducted; from their outward conduct, their cleanliness, and faithful observance of their strange religious rites, it was impossible to look at them with the same eyes as on our wretched convicts in New South Wales.

May 1st.-Sunday. I took a quiet walk along the sea-coast to the north of the town. The plain in this part is quite uncultivated: it consists of a field of black lava, smoothed over with coarse grass and bushes, the latter being chiefly Mimosas. The scenery may be described as intermediate in character between that of the Galapagos and of Tahiti; but this will convey a definite idea to very few persons. It is a very pleasant country, but it has not the charms of Tahiti, or the grandeur of Brazil. The next day I ascended La Pouce, a mountain so called from a thumb-like projection, which rises close behind the town to a height of 2600 feet. The centre of the island consists of a great platform, surrounded by old, broken basaltic mountains, with their strata dipping seawards. The central platform, formed of comparatively recent streams of lava, is of an oval shape, thirteen 
geographical miles across, in the line of its shorter axis. The exterior bounding mountains come into that class of structures called Craters of Elevation, which are supposed to have been formed, not like ordinary craters, but by a great and sudden upheaval. There appears to me to be insuperable objections to this view : on the other hand, I can hardly believe, in this and some other cases, that these marginal crateriform mountains are merely the basal remnants of immense volcanoes, of which the summits either have been blown off, or swallowed up in subterranean abysses.

From our elevated position we enjoyed an excellent view over the island. The country on this side appears pretty well cultivated, being divided into fields, and studded with farm-houses. I was, however, assured, that of the whole land, not more than half is yet in a productive state; if such be the case, considering the present large export of sugar, this island, at some future period, when thickly peopled, will be of great value. Since England has taken possession of it, a period of only twenty-five years, the export of sugar is said to have increased seventy-five fold. One great cause of its prosperity is the excellent state of the roads. In the neighbouring Isle of Bourbon, which remains under the French goverument, the roads are still in the same miserable state as they were here only a few years ago. Although the French residents must have largely profited by the increased prosperity of their island, yet the English government is far from popular.

3d.-In the evening, Captain Lloyd, the Surveyor-general, so well known from his examination of the Isthmus of Panama, invited Mr. Stokes and myself to his country-house, which is situated on the edge of Wilheim Plains, and about six miles 
from the Port. We stayed at this delightful place two days: standing nearly 800 feet above the sea, the air was cool and fresh, and on every side there were delightful walks. Close by, a grand ravine has been worn to a depth of about 500 feet through the slightly-inclined streams of lava which have flowed from the central platform.

5th.-Captain Lloyd took us to the Rivière Noire, which is several miles to the suuthward, that I might examine some rocks of elevated coral. We passed through pleasant gardens and fine fields of sugar-cane growing amidst huge blocks of lava. The roads were bordered by hedges of Mimosa, and near many of the houses there were avenues of the mango. Some of the views, where the peaked hills and the cultivated farms were seen together, were exceedingly picturesque, and we were constantly tempted to exclaim, "How pleasant it would be to pass one's life in such quiet abodes!" Captain Lloyd possessed an elephant, and he sent it half way with us, that we might enjoy a ride in true Indian fashion. The circumstance which surprised me most was its quite noiseless step. This elephant is the only one at present on the island, but it is said others will be sent for.

May 9th.-We sailed from Port Louis, and, calling at the Cape of Good Hope, on the 8th of July we arrived off St. Helena. This island, the forbidding aspect of which has been so often described, rises abruptly, like a luge black castle, from the ocean. Near the town, as if to complete nature's defence, small forts and guns fill up every gap in the rugged rocks. The town runs up a flat and narrow valley; the houses look respecta$\mathrm{ble}$, and are interspersed with a very few green 
trees. When approaching the anchorage there was one striking view : an imegular castle perched on the summit of a lofty hill, and surrounded by a few scattered fir-trees, boldly projected against the sky.

'The next day I obtained lodgings within a stone's throw of Napoleon's tomb:* it was a capital central situation, whence I could make excursions in every direction. During the four days I stayed here, I wandered over the island from morning to night, and examined its geological history. My lodgings were situated at a height of about 2000 feet; here the weather was cold and boisterous, with constant showers of rain; and every now and then the whole scene was veiled in thick clouds.

Near the coast the rough lava is quite bare: in the central and higher parts, feldspathic rocks, by their decomposition, have produced a clayey soil, which, where not covered by vegetation, is stained in broad bands of many bright colours. At this season the land, moistened by constant showers, produces a singularly bright green pasture, which, lower and lower down, gradually fades away and at last disappears. In latitude $16^{\circ}$, and at the trifling elevation of 1500 feet, it is surprising to behold a vegetation possessing a character decidedly British. The hills are crowned with irregular plantations of Scotch firs, and the sloping banks are thickly scattered over with thickets of gorse, covered with its bright yellow flowers. Weeping willows are common on the banks of the rivulets, and the hedges are made of the blackberry, producing its well-known fruit. When we consider

* After the volumes of eloquence which have poured forth on this subject, it is dangerous even to mention the tomb. A modern traveller, in twelve lines, burdens the poor little island with the following titles-it is a grave, tomb, pyramid, cemetery, sepulchre, catacomb, sarcophagus, minaret, and mausoleum! 
that the number of plants now found on the island is 746, and that out of these fifty-two alone are indigenous species, the rest having been imported, and most of them from England, we see the reason of the British character of the vegetation. Many of these English plants appear to flourish better than in their native country; some also from the opposite quarter of Australia succeed remarkably well. The many imported species must have destroyed some of the native kinds, and it is only on the highest and steepest ridges that the indigenous Flora is now predominant.

The English, or, rather, Welsh character of the scenery is kept up by the numerous cottages and small white houses, some buried at the bottom of the deepest valleys, and others mounted on the crests of the lofty hills. Some of the views are striking ; for instance, that from near Sir W. Doveton's house, where the bold peak called Lot is seen over a dark wood of firs, the whole being backed by the red water-worn mountains of the southern coast. On viewing the island from an eminence, the first circumstance which strikes one is the number of the roads and forts: the labour bestowed on the public works, if one forgets its character as a prison, seems out of all proportion to its extent or value. There is so little level or useful land, that it seems surprising how so many people, about 5000, can subsist here. The lower orders, or the emancipated slaves, are, I believe, extremely poor: they complain of the want of work. From the reduction in the number of public servants, owing to the island having been given up by the East India Company, and the consequent emigration of many of the richer people, the poverty probably will increase. The chief food of the working class is rice, with a little salt meat: as 
neither of these articles are the products of the island, but must be purchased with money, the low wages tell heavily on the poor people. Now that the people are blessed with freedom, a right which I believe they value fully, it seems probable that their numbers will quickly increase: if so, what is to become of the little state of St. Helena?

My guide was an elderly man, who had been a goatherd when a boy, and knew every step amongst the rocks. He was of a race many times crossed, and although with a dusky skin, he had not the disagreeable expression of a mulatto. He was a very civil, quiet old man, and such appears the character of the greater number of the lower classes. It was strange to my ears to hear a man, nearly white, and respectably dressed, talking with indifference of the times when he was a slave. With my companion, who carried our dinners and a horn of water, which is quite necessary, as all the water in the lower valleys is saline, I every day took long walks.

Beneath the upper and central green circle, the wild valleys are quite desolate and untenanted. Here, to the geologist, there were scenes of high interest, showing successive changes and complicated disturbances. According to my views, St. Helena has existed as an island from a very remote epoch: some obscure proofs, however, of the elevation of the land are still extant. I believe that the central and highest peaks form parts of the rim of a great crater, the southern half of which has been entirely removed by the waves of the sea : there is, moreover, an external wall of black basaltic rocks, like the coast-mountains of Mauritius, which are older than the central volcanic streams. On the higher parts of the island, considerable numbers of a shell, long thought a marine 
species, occur embedded in the soil. It proves to be a Cochlogena, or land-shell of a very peculiar form ;* with it I found six other kinds; and in another spot an eighth species. It is remarkable that none of them are now found living. Their extinction has probably been caused by the entire destruction of the woods, and the consequent loss of food and shelter, which occurred during the early part of the last century.

The history of the changes which the elevated plains of Longwood and Deadwood have undergone, as given in General Beatson's account of the island, is extremely curious. Both plains, it is said, in former times were covered with wood, and were therefore called the Great Wood. So late as the year 1716 there were many trees, but in 1724 the old trees had mostly fallen; and as goats and hogs had been suffered to range about, all the young trees had been killed. It appears also from the official records that the trees were unexpectedly, some years afterwards, succeeded by a wire grass, which spread over the whole surface. $\dagger$ General Beatson adds, that now this plain " is covered with fine sward, and is become the finest piece of pasture on the island." - The extent of surface, probably covered by wood at a former period, is estimated at no less than two thousand acres; at the present day scarcely a single tree can be found there. It is also said that in 1709 there were quantities of dead trees in Sandy Bay; this place is now so utterly desert, that nothing but so well attested an account could have made me believe that they could ever have grown there. The fact that the goats and hogs destroyed all the young * It deserves notice, that all the many specimens of this shell found by me in one spot differ, as a marked variety, from another set of specimens procured from a different spot.

† Beatson's St. Helena. Introductory chapter, p. 4.

II. 19 
trees as they sprang up, and that in the course of time the old ones, which were safe from their attacks, perished from age, seems clearly made out. Goats were introduced in the year 1502 ; eightysix years afterwards, in the time of Cavendish, it is kuown that they were exceedingly numerous. More than a century afterwards, in 1731, when the evil was complete and irretrievable, an order was issued that all stray animals should be destroyed. $1 \mathrm{t}$ is very interesting thus to find that the arrival of animals at St. Helena in 1501 did not change the whole aspect of the island until a period of two hundred and twenty years had elapsed; for the goats were introduced in 1502 , and in 1724 it is said "the old trees had mostly fallen." There can be little doubt that this great change in the vegetation affected not only the landshells, causing eight species to become extinct, but likewise a multitude of insects.

St. Helena, situated so remote from any continent. in the midst of a great ocean, and possessing a unique Flora, excites our curiosity. 'The eight land-shells, though now extinct, and one living Succinea, are peculiar species found nowhere else. Mr. Cuming, however, informs me that an English Helix is common here, its eggs no doubt having been imported in some of the many introduced plants. Mr. Cuming collected on the coast sixteen species of sea-shells, of which seven, as far as he knows, are confined to this island. Birds and insects, ${ }^{*}$ as might have been expected, are very few

* Among these few insects, I was surprised to find a small Aphodius (nov. spec.) and an Oryctes, both extremely numerous under dung. When the island was discovered it certainly possessed no quadruped, excepting, perhaps, a mouse : it becomes, therefore, a difficuit point to ascertain whether these stercovorous insects have since been imported by accident, or, if aborigines, on what food they formerly subsisted. On the banks of the Plata, where, from the vast number of cattle and horses, the fine plains 
in number; indeed, I believe all the birds have been introduced within late years. Partridges and pheasants are tolerably abundant: the island is much too English not to be subject to strict gamelaws. I was told of a more unjust sacrifice to such ordinances than I ever heard of even in England. The poor people formerly used to burn a plant, which grows on the coast-rocks, and export the soda from its ashes; but a peremptory order came out prohibiting this practice, and giving as a reason that the partridges would have nowhere to build!

In my walks I passed more than once over the grassy plain, bounded by deep valleys, on which Longwood stands. Viewed from a short distance, of turf are richly manured, it is vain to seek the many kinds of dung-feeding beetles, which occur so abundantly in Europe. I observed only an Oryctes (the insects of this genus in Europe generally feed on decayed vegetable matter) and two species of Phanæus, common in such situations. On the opposite side of the Cordillera in Chiloe, another species of Phanæus is exceedingly abundant, and it buries the dung of the cattle in large earthen balls beneath the ground. There is reason to believe that the genus Phanæus, before the introduction of cattle, acted as scavengers to man. In Europe, beetles, which find support in the matter which has already contributed towards the life of other and larger animals, are so numerous, that there must be considerably more than one hundred different species. Considering this, and observing what a quantity of food of this kind is lost on the plains of La Plata, I imagined I saw an instance where man had disturbed that cbain, by which so many animals are linked together in their native country. In Van Diemen's Land, however, I found four species of Onthophagus, two of Aphodius, and one of a third genus, very abundant under the dung of cows; yet these latter animals had been then introduced only thïry-three years. Previously to that time, the Kangaroo and some other small animals were the only quadrupeds; and their dung is of a very different quality from that of their successors introduced by man. In Eng. land the greater number of stercovorous beetles are confined in their appetites; that is, they do not depend indifferently on any quadruped for the means of subsistence. The change, therefore, in habits, which must have taken place in Van Diemen's Land, is highly remarkable. I am indebted to the Rev. F. W. Hope, who, I hope, will permit me to call him my master in Entomology, for giving me the names of the foregoing insects. 
it appears like a respectable gentleman's countryseat. In front there are a few cultivated fields, and beyond them the smooth hill of coloured rocks called the Flagstaff, and the rugged, square black mass of the Barn. On the whole, the view was rather bleak and uninteresting. The only inconvenience I suffered during my walks was from the impetuous winds. One day I noticed a curious circumstance: standing on the edge of a plain, terminated by a great clifl of about a thousand feet in depth, I saw, at the distance of a few yards right to windward, some tern, struggling against a very strong loreeze, whilst where 1 stood the air was quite calm. Approaching close to the brink, where the current seemed to be deflected upwards from the face of the cliff, I stretched out my arm, and inmediately felt the full force of the wind: an invisible barrier, two yards in widtll, separated perfectly calm air from a strong blast.

I so much enjoyed my rambles among the rocks and mountains of St. Helena, that I felt almost sorry, on the morning of the 14th, to descend to the town. Before noon I was on board, and the Beagle made sail.

On the 19th of July we reached Ascension. Those who have beheld a volcanic island situated under an arid climate will at once be able to picture to themselves the appearance of Ascension. They will imagine smooth conical hills of a bright red colour, with their summits generally truncated, rising separately out of a level surface of black, rugged lava. A principal mound in the centre of the island seems the father of the lesser cones. It is called Green Hill; its name being taken from the faintest tinge of that colour, which at this time of the year is barely perceptible from the anchor- 
age. To complete the desolate scene, the black rocks on the coast are lashed by a wild and turbulent sea.

The settlement is near the beach : it consists of several houses and barracks placed irregularly, but well built of white freestone. The only inhabitants are marines, and some negroes liberated from slaveships, who are paid and victualled by government. There is not a private person on the island. Many of the marines appeared well contented with their situation; they think it better to serve their oneand-twenty years on shore, let it be what it may, than in a ship: in this choice, if I were a marine, I should most heartily agree.

The next morning I ascended Green Hill, 2840 feet high, and thence walked across the island to the windward point. A good cart-road leads from the coast-settlement to the houses, gardens, and fields, placed near the summit of the central mountain. On the roadside there are milestones, and likewise cisterns, where each thirsty passer-by can drink some good water. Similar care is displayed in each part of the establishment, and especially in the management of the springs, so that a single drop of water may not be lost: indeed, the whole island may be compared to a huge ship kept in first-rate order. I could not help, when admiring the active industry which had created such effects out of such means, at the same time regretting that it had been wasted on so poor and trifling an end. M. Lesson has remarked with justice, that the English nation alone would have thought of making the island of Ascension a productive spot; any other people would have held it as a mere fortress in the ocean.

Near this coast nothing grows; further inland, an occasional green castor-oil plant, and a few $\mathrm{B}$ в 2 
grasshoppers, true friends of the desert, may be met with. Some grass is scattered over the surface of the central elevated region, and the whole much resembles the worse parts of the Welsh mountains; but scanty as the pasture appears, about six hundred sheep, many goats, a few cows and horses, all thrive well on it. Of native animals, land-crabs and rats swarm in numbers. Whether the rat is really indigenous may well be doubted: there are two varieties, as described by Mr. Waterhouse; one is of a black colour, with fine glossy fur, and lives on the grassy summit; the other is brown-coloured and less glossy, with longer hairs, and lives near the settlement on the coast. Both these varieties are one third smaller than the common black rat (M. rattus), and they differ from it both in the colour and character of their fur, but in no other essential respect. I can hardly doubt that these rats (like the common mouse, which has also run wild) have been imported, and, as at the Galapagos, have varied from the effect of the new conditions to which they have been exposed: hence the variety on the summit of the island differs from that on the coast. Of native birds there are none; but the guinea-fowl, imported from the Cape de Verd Islands, is abundant, and the common fowl has likewise run wild. Some cats, which were originally turned out to destroy the rats and mice, have increased so as to become a great plague. The island is entirely withont trees, in which, and in every other respect, it is very far inferior to St. Helena.

One of my excursions took me towards the S.W. extremity of the island. The day was clear and hot, and I saw the island, not smiling with beauty, but staring with naked hideousness. The lavastreams are covered with hummocks, and are rng- 
ged to a degree which, geologically speaking, is not of easy explanation. The intervening spaces are concealed with layers of pumice, ashes, and volcanic tuff. Whilst passing this end of the island at sea, I could not imagine what the white patches were with which the whole plain was mottled; I now found that they were seafowl, sleeping in such full confidence, that even in midday a man could walk up and seize hold of them. These birds were the only living creatures I saw during the whole day. On the beach a great surf, although the breeze was light, came tumbling over the broken lava rocks.

The geology of this island is in many respects interesting. In several places I noticed volcanic bombs, that is, masses of lava which have been shot through the air whilst fluid, and have consequently assumed a spherical or pear shape. Not only their external form, but, in several cases, their internal structure, shows in a very curious manner that they have revolved in their aerial course. The internal structure of one of these bombs, when broken, is represented very accurately in the woodcut on the next page. The central part is coarsely cellular, the cells decreasing in size towards the exterior, where there is a shell-like case about the third of an inch in thickness, of compact stone, which again is overlaid by the outside crust of finely cellular lava. I think there can be little doubt, first, that the external crust cooled rapidly in the state in which we now see it; secondly, that the still fluid lava within was packed by the centrifugal force, generated by the revolving of the bomb, against the external cooled crust, and so produced the solid shell of stone; and, lastly, that the centrifugal force, by relieving the pressure in the more central parts of the bomb, allowed the heated va. 


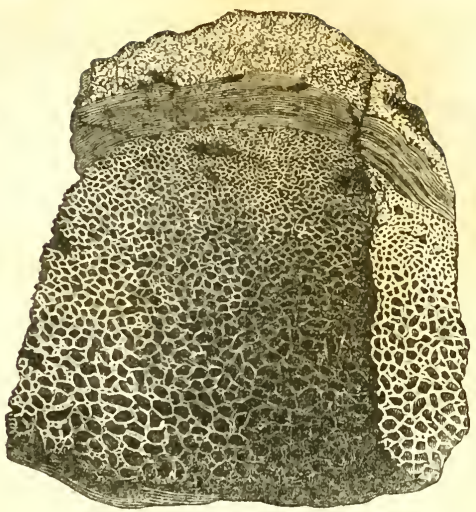

pours to expand their cells, thus forming the coarsely cellular mass of the centre.

A hill, formed of the older series of volcanic rocks, and which has been incorrectly considered as the crater of a volcano, is remarkable from its broad, slightly hollowed, and circular summit having been filled up with many successive layers of ashes and fine scoriæ. These saucer-shaped layers crop out on the margin, forming perfect rings of many different colours, giving to the summit a most fantastic appearance; one of these rings is white and broad, and resembles a course round which horses have been exercised; hence the hill has been called the Devil's Riding School. I brought away specimens of one of the tufaceous layers of a pinkish colour; and it is a most extraordiuary fact that Professor Ehrenberg* finds it almost wholly com* Monats. der König. Akad. d. Wiss. zu Berlin. Vom A pril, 1845, 
posed of matter which has been organized: he detects in it some siliceous-shielded, fresh-water infusoria, and no less than twenty-five different kinds of the siliceous tissue of plants, chiefly of grasses. From the absence of all carbonaceous matter, Professor Ehrenberg believes that these organic bodies have passed through the volcanic fire, and have been erupted in the state in which we now see them. The appearance of the layers induced me to believe that they had been deposited under water, though, from the extreme dryness of the climate, I was forced to imagine that torrents of rain had probably fallen during some great eruption, and that thus a temporary lake had been formed into which the ashes fell. But it may now be suspected that the lake was not a temporary one. Anyhow, we may feel sure that at some former epoch the climate and productions of Ascension were very different from what they now are. Where on the face of the earth can we find a spot on which close investigation will not discover signs of that endless cycle of change to which this earth has been, is, and will be subjected?

Un leaving Ascension we sailed for Bahia, on the coast of Brazil, in order to complete the chronometrical measurement of the world. We arrived. there on August 1st, and stayed four days, during which I took several long walks. I was glad to find my enjoyment in tropical scenery had not decreased from the want of novelty, even in the slightest degree. The elements of the scenery are so simple, that they are worth mentioning, as a proof on what trifling circumstances exquisite natural beauty depends.

The country may be described as a level plain of about three hundred feet in elevation, which in all parts has been worn into flat-bottomed valleys. 
This structure is remarkable in a granitic land, but is nearly universal in all those softer formations of which plaius are usually composed. The whole surface is covered by various kinds of stately trees, interspersed with patches of cultivated ground, out of which houses, convents, and chapels arise. It must be remembered that within the tropics the wild luxuriance of nature is not lost even in the vicinity of large cities; for the natural vegetation of the hedges and hillsides overpowers in picturesque effect the artificial labour of man. Hence there are only a few spots where the bright red soil affords a strong contrast with the universal clothing of green. From the edges of the plain there are distant views either of the ocean, or of the great Bay with its low-wooded shores, and on which numerous boats and canoes show their white sails. Excepting from these points, the scene is extremely limited; following the level pathways on each hand, only glimpses into the wooded valleys below can he obtained. The houses, I may add, and especially the sacred edifices, are built in a peculiar and rather fantastic style of architecture. They are all whitewashed; so that when illumined by the brilliant sun of midday, and as seen against the pale blue sky of the horizon, they stand out more like shadows than real buildings.

Such are the elements of the scenery, but it is a hopeless attempt to paint the general effect. Learned naturalists describe these scenes of the tropics by naming a multitude of objects, and mentioning some characteristic feature of each. To a learned traveller this possibly may communicate some definite ideas : but who else, from seeing a plant in an herbarium, can imagine its appearance when growing in its native soil? Who, from seeing choice plants in a hot-house, can magnify some 
into the dimensions of forest-trees, and crowd others into an entangled jungle? Who, when examining in the cabinet of the entomologist the gay exotic butterflies and singular cicadas, will associate with these lifeless objects the ceaseless harsh music of the latter, and the lazy flight of the former, the sure accompaniments of the still, glowing noonday of the tropics? It is when the sun has attained its greatest height that such scenes should be viewed: then the dense, splendid foliage of the mango hides the ground with its darkest shade, whilst the upper branches are rendered, from the profusion of light, of the most brilliant green. In the temperate zones the case is different; the vegetation there is not so dark or so rich, and hence the rays of the declining sun, tinged of a red, purple, or bright yellow colour, add most to the beauties of those climes.

When quietly walking along the shady pathways, and admiring each successive view, I wished to find language to express my ideas. Epithet after epithet was found too weak to convey to those who have not visited the intertropical regions the sensation of delight which the mind experiences. I have said that the plants in a hothouse fail to communicate a just idea of the vegetation, yet I must recur to it. The land is one great wild, untidy, luxuriant hot-house, made by Nature for herself, but taken possession of by man, who has studded it with gay houses and formal gardens. How great would be the desire in every admirer of nature to behold, if such were possible, the scenery of another planet! yet to every person in Europe it may be truly said, that at the distance of only a few degrees from his native soil the glories of another world are opened to him. In my last walk I stopped again and again to gaze on $\mathrm{R}$ 
these beauties, and endeavoured to fix in my mind forever an impression which at the time I knew sooner or later must fail. The form of the orangetree, the cocoa-nut, the palm, the mango, the treefern, the banana, will remain clear and separate; but the thousand beauties which unite these into one perfect scene must fade away; yet they will leave, like a tale heard in childhood, a picture full of indistinct but most beautiful figures.

August 6th.-In the afternoon we stood out to sea, with the intention of making a direct course to the Cape de Verd Islands. Unfavourable winds, however, delayed us, and on the 12 th we ran into Pernambuco, a large city on the coast of Brazil, in latitude $8^{\circ}$ south. We anchored outside the reef; but in a short time a pilot came on board and took us into the inner harbour, where we lay close to the town.

Pernambuco is built on some narrow and low sand-banks, which are separated from each other by shoal channels of salt water. The three parts of the town are connected together by two long bridges built on wooden piles. The town is in all parts disgusting, the streets being narrow, ill paved, and filthy; the louses tall and gloomy. The season of heavy rains had hardly come to an end, and hence the surrounding country, which is scarcely raised above the level of the sea, was flooded with water, and I failed in all my attempts to take long walks.

The flat, swampy land on which Pernambuco stands is surrounded, at the distance of a few miles, by a semicircle of low hills, or rather by the edge of a country elevated perhaps two hundred feet above the sea. The old city of Olinda stands on one extremity of this range. One day 1 took a canoe, and proceeded up one of the channels to visit it; 
I found the old town, from its situation, both sweeter and cleaner than that of Pernambuco. I must here commemorate what happened for the first time during our nearly five years' wandering, namely, having met with a want of politeness : I was refused in a sullen manner at two different houses, and obtained with difficulty from a third permission to pass through their gardens to an uncultivated hill, for the purpose of viewing the country. I feel glad that this happened in the land of the Brazilians, for I bear them no good will-a land also of slavery, and therefore of moral debasement. A Spaniard would have felt ashamed at the very thought of refusing such a request, or of behaving to a stranger with rudeness. The channel by which we went to and returned from Olinda was bordered on each side by mangroves, which sprang like a miniature forest out of the greasy mud-banks. The bright green colour of these bushes always reminded me of the rank grass in a churchyard: both are nourished by putrid exhalations; the one speaks of death past, and the other too often of death to come.

The most curious object which I saw in this neighbourhood was the reef that forms the harbour. I doubt whether in the whole world any other natural structure has so artificial an appearance.* It runs for a length of several miles in an absolutely straight line, parallel to, and not far distant from, the shore. It varies in width from thirty to sixty yards, and its surface is level and smooth; it is composed of obscurely-stratified hard sandstone. At high water the waves break over it; at low water its summit is left dry, and it might then be mistaken for a breakwater erected by Cyclope-

* I have described this Bar in detail in the Lond. and Edin. Phil. Mag., vol. xix. (1841), p. 257.

$$
\text { II. - C c }
$$


an workmen. On this coast the currents of the sea tend to throw up in front of the land long spits and bars of loose sand, and on one of these part of the town of Permambuco stands. In former times, a long spit of this nature seems to have become consolidated by the percolation of calcareous matter, and afterwards to have been gradually upheaved, the outer and loose parts during this process having been wom away by the action of the sea, and the solid nucleus left as we now see it. Although night and day the waves of the open Atlantic, turbid with sediment, are driven against the steep outside edges of this wall of stone, yet the oldest pilots know of no tradition of any change in its appearance. This durability is much the most curious fact in its history : it is due to a tough layer, a few inches thick, of calcareous matter, wholly formed by the successive growth and death of the small shells of Serpulæ, together with some few barnacles and nulliporæ. These nullipora, which are hard, very simply-organized sea-plants, play an analogous and important part in protecting the upper surfaces of coral-reefs, behind and within the breakers, where the true corals, luring the outward growth of the mass, become killed by exposure to the sun and air. These insignificant organic beings, especially the Serpulæ, have done good service to the people of Pernambuco; for without their protective aid the bar of sandstone would inevitably have been long ago worn away, and without the bar there would have been no harbour.

On the 19th of August we finally left the shores of Brazil. I thank God I shall never again visit a slave-country. To this day, if I hear a distant scream, it recalls with painful vividness my feelings, when, passing a house near Pernambuco, I heard the most pitiable moans, and could not but 
suspect that some poor slave was being tortured, yet knew that I was as powerless as a child even to remonstrate. I suspected that these moans were from a tortured slave, for I was told that this was the case in another instance. Near Rio de Janeiro I lived opposite to an old lady who kept screws to crush the fingers of her female slaves. I have stayed in a house where a young household mulatto daily and hourly was reviled, beaten, and persecuted enough to break the spirit of the lowest animal. I have seen a little boy, six or seven years old, struck thrice with a horsewhip (before I could interfere) on his naked head for having handed me a glass of water not quite clean; I saw his father tremble at a mere glance from his master's eye. These latter cruelties were witnessed by me in a Spanish colony, in which it has always been said that slaves are better treated than by the Portuguese, English, or other European nations. I have seen at Rio Janeiro a powerful negro afraid to ward off a blow directed, as he thought, at his face. I was present when a kind-hearted man was on the point of separating forever the men, women, and little children of a large number of families who had long lived together. I will not even allude to the many heart-sickening atrocities which I authentically heard of; nor would I have mentioned the above revolting details had I not met with several people so blinded by the constitutional gayety of the negro as to speak of slavery as a tolerable evil. Such people have generally visited at the houses of the upper classes, where the domestic slaves are usually well treated; and they have not, like myself, lived amongst the lower classes. Such enquirers will ask slaves about their condition; they forget that the slave must indeed be dull who does not calculate on the chance of his answer reaching his master's ear's. 
It is argued that self-interest will prevent excessive cruelty; as if self-interest protected our domestic animals, which are far less likely than degraded slaves to stir up the rage of their savage masters. It is an argument long since protested against with noble feeling, and strikingly exemplified, by the ever illustrious Humboldt. It is often attempted to palliate slavery by comparing the state of slaves with our poorer countrymen: if the misery of our poor be caused, not by the laws of nature, but by our institutions, great is our sin; but how this bears on slavery I cannot see; as well might the use of the thumb-screw be defended in one land, by showing that men in another land suffered from some dreadful disease. Those who look tenderly at the slave-owner, and with a cold heart at the slave, never scem to put themselves into the position of the latter-what a cheerless prospect, with not even a hope of change! Picture to yourself the chance, ever hanging over you, of your wife and your little children-those objects which nature urges even the slave to call his own -being torn from you and sold like beasts to the first bidder! And these deeds are done and palliated by men who profess to love their neighbours as themselves; who believe in God, and pray that his will be done on eartl!! It makes one's blood boil, yet heart tremble, to think that we Englishmen and our American descendants, with their boastful cry of liberty, have been and are so guilty: but it is a consolation to reflect that we, at least, have made a greater sacrifice than ever made by any nation to expiate our sin.

On the last day of August we anchored for the second time at Porto Praya, in the Cape de Verd Archipelago; thence we proceeded to the Azores, 
where we stayed six days. On the $2 d$ of October we made the shores of England, and at Falmouth I left the Beagle, having lived on board the good little vessel nearly five years.

Our voyage having come to an end, I will take a short retrospect of the advantages and disadvantages, the pains and pleasures, of our circumnavigation of the world. If a person asked my advice before undertaking a long voyage, my answer would depend upon his possessing a decided taste for some branch of knowledge, which could by this means be advanced. No doubt it is a ligh satisfaction to behold various countries and the many races of mankind, but the pleasures gained at the time do not counterbalance the evils. It is necessary to look forward to a harvest, however distant that may be, when some fruit will be reaped, some good effected.

Many of the losses which must be experienced are obvious, such as that of the society of every old friend, and of the sight of those places with which every dearest remembrance is so intimately connected. These losses, however, are at the time partly relieved by the exhaustless delight of anticipating the long-wished-for day of return. If, as poets say, life is a dream, I am sure, in a voyage, these are the visions which best serve to pass a way the long night. Other losses, although not at first felt, tell heavily after a period: these are the want of room, of seclusion, of rest; the jading feeling of constant hurry ; the privation of small luxuries, the loss of domestic society, and even of music and the other pleasures of imagination. When such trifles are mentioned, it is evident that the real grievances, excepting from accidents, of a sea-life are at an end. The short space of sixty years has II. 
made an astonishing difference in the facility of distant navigation. Even in the time of Cook, a man who left his fireside for such expeditions underwent severe privations. A yacht now, with every luxury of life, can circumnavigate the globe. Besides the vast improvements in ships and naval resources, the whole western shores of America are thrown open, and Australia has become the capital of a rising continent. How different are the circumstances to a man shipwrecked at the present day in the Pacific, to what they were in the time of Cook! Since his voyage a hemisphere has been added to the civilized world.

If a person suffer much from sea-sickness, let him weigh it heavily in the balance. I speak from experience : it is no trifling evil, cured in a week. If, on the other hand, he take pleasure in naval tactics, he will assuredly have full scope for his taste; but it must be borne in mind how large a proportion of the time during a long voyage is spent on the water as compared with the days in harbour. And what are the boasted glories of the illimitable ocean? A tedious waste, a desert of water, as the Arabian calls it. No doubt there are some delightful scenes. A moonlight night, with the clear heavens and the dark glittering sea, and the white sails filled by the soft air of a gentlyblowing trade-wind; a dead calm, with the heaving surface polished like a mirror, and all still except the occasional flapping of the canvass. It is well once to behold a squall with its rising arch and coming fury, or the heavy gale of wind and mountainous waves. I confess, however, my imagination had painted something more grand, more terrific in the full-grown storm. It is an incomparably finer spectacle when beheld on shore, where the waving trees, the wild flight of the birds, the dark 
shadows and bright lights, the rushing of the torrents, all proclaim the strife of the unloosed elements. At sea the albatross and little petrel fly as if the storm were their proper sphere, the water rises and sinks as if fulfilling its usual task, the ship alone and its inhabitants seem the objects of wrath. On a forlorn and weather-beaten coast, the scene is indeed different, but the feelings partake more of horror than of wild delight.

Let us now look at the brighter side of the past time. The pleasure derived from beholding the scenery, and the general aspect of the various countries we have visited, has decidedly been the most constant and highest source of enjoyment. It is probable that the picturesque beauty of many parts of Europe exceeds anything which we beheld. But there is a growing pleasure in comparing the character of the scenery in different countries, which, to a certain degree, is distinct from merely admiring its beauty. It depends chiefly on an acquaintance with the individual parts of each view : $I$ am strongly induced to believe that, as in music, the person who understands every note will, if he also possesses a proper taste, more thoroughly enjoy the whole, so he who examines each part of a fine view may also thoroughly comprehend the full and combined effect. Hence a traveller should be a botanist, for in all views plants form the chief embellishment. Group masses of naked rock even in the wildest forms, and they may for a time afford a sublime spectacle, but they will soon grow monotonous. Paint them with bright and varied colours, as in Northern Chile, they will become fantastic; clothe them with vegetation, they must form a decent, if not a beautiful picture.

When I say that the scenery of parts of Europe is probably superior to anything which we beheld, 
I except, as a class by itself, that of the intertropical zomes. The two classes camnot be compared together; but I have already often enlarged on the grande ur of those regions. As the force of impressions generally depends on preconceived ideas, I may add, that mine were taken from the vivid descriptions in the Personal Narrative of Humboldt, which far exceed in merit anything else which I have read. Yet, with these high-wrought ideas, my feelings were far from partaking of a tinge of disappointment on my first and final landing on the shores of Brazil.

Among the scenes which are deeply impressed on my mind, none excecd in sublimity the primeval forests undefaced by the hand of man; whether those of Brazil, where the powers of Life are predominant, or those of Tierra del Fuego, where Death and Decay prevail. Both are temples filled with the varied productions of the God of Nature: no one can stand in these solitudes ummoved, and not feel that there is more in man than the mere breath of his body. In calling up images of the past, I find that the plains of Patagonia frequently cross before my eyes; yet these plains are pronounced by all wretched and useless. They can be described only by negative characters; without habitations, without water, without trees, without mountains, they support merely a few dwarf plants. Why, then, and the case is not peculiar to myself, have these arid wastes taken so firm a hold on my memory? Why have not the still more level, the greener and more fertile Pampas, which are serviceable to mankind, produced an equal impression? I can scarcely analyze these feelings; but it must be partly owing to the free scope given to the imagination. The plains of Patagonia are boundless, for they are scarcely passable, and hence un- 
known : they bear the stamp of having lasted, as they are now, for ages, and there appears no limit to their duration through future time. If, as the ancients supposed, the flat earth was surrounded by an impassable breadth of water, or by deserts heated to an intolerable excess, who would not look at these last boundaries to man's knowledge with deep but ill-defined sensations?

Lastly, of natural scenery, the views from lofty mountains, though certainly in one sense not beautiful, are very memorable. When looking down from the highest crest of the Cordillera, the mind, undisturbed by minute details, was filled with the stupendous dimensions of the surrounding masses.

Of individual objects, perhaps nothing is more certain to create astonishment than the first sight in his native haunt of a barbarian-of man in his lowest and most savage state. One's mind hurries back over past centuries, and then asks, could our progenitors have been men like these? men, whose very signs and expressions are less intelligible to us than those of the domesticated animals; men who do not possess the instinct of those animals, nor yet appear to boast of human reason, or at least of arts consequent on that reason. I do not believe it is possible to describe or paint the difference between savage and civilized man. It is the difference between a wild and tame animal; and part of the interest in beholding a savage is the same which would lead every one to desire to see the lion in his desert, the tiger tearing his prey in the jungle, or the rhinoceros wandering over the wild plains of Africa.

Among the other most remarkable spectacles which we have beheld, may be ranked the Southern Cross, the cloud of Magellan, and the other constellations of the southern hemisphere-the wa- 
ter-spout-the glacier leading its blue stream of ice, overhanging the sea in a bold precipice - a lagoon-island raised by the reef-building coralsan active volcano-and the overwhelming effects of a violent earthquake. These latter phenomena, perhaps, possess for me a peculiar interest, from their intimate connexion with the geological structure of the world. The earthquake, however, must be to every one a most impressive event: the earth, considered from our earliest childhood as the type of solidity, has oscillated like a thin crust beneath our feet; and in seeing the laboured works of man in a moment overtlurown, we feel the insignificance of his boasted power.

It has been said that the love of the chase is an inherent delight in man-a relic of an instinctive passion. If so, 1 am sure the pleasure of living in the open air, with the sky for a roof and the ground for a table, is part of the same feeling; it is the savage returning to his wild and native habits. I always look back to our boat cruises, and my land journeys, when through unfrequented countries, with an extreme delight, which no scenes of civilization could have created. I do not doubt that every traveller must remember the glowing sense of happiness which he experienced when lhe first breathed in a foreign clime, where the civilized man had seldom or never trod.

There are several other sources of enjoyment in a long voyage which are of a more reasonable nature. The map of the world ceases to be a blank; it becomes a picture full of the most varied and animated figures. Each part assumes its proper dimensions : continents are not looked at in the light of islands, or islands considered as mere specks, which ars, in truth, larger than many kingdoms of Europe. Africa, or North and South America, 
are well-sounding names, and easily pronounced; but it is not until having sailed for weeks along small portions of their shores that one is thoroughly convinced what vast spaces on our immense world these names imply.

From seeing the present state, it is impossible not to look forward with high expectations to the future progress of nearly an entire hemisphere. The march of improvement, consequent on the introduction of Christianity throughout the South Sea, probably stands by itself in the records of history. It is the more striking when we remember that only sixty years since, Cook, whose excellent judgment none will dispute, could foresee no prospect of a change. Yet these changes have now been effected by the philanthropic spirit of the British nation.

In the same quarter of the globe Australia is rising, or, indeed, may be said to have risen, into a grand centre of civilization, which, at some not very remote period, will rule as empress over the southern hemisphere. It is impossible for an Englishman to behold these distant colonies without a high pride and satisfaction. To hoist the British flag seems to draw with it as a certain consequence, wealth, prosperity, and civilization.

In conclusion, it appears to me that nothing can , be more improving to a young naturalist than a journey in distant countries. It both sharpens, and partly allays that want and craving which, as Sir J. Herschel remarks, a man experiences although every corporeal sense be fully satisfied. The excitement from the novelty of objects, and the chance of success, stimulate him to increased activity. Moreover, as a number of isolated facts soon become uninteresting, the habit of comparison leads to generalization. On the other hand, 
as the traveller stays but a short time in each place, his descriptions inust generally consist of mere sketches instead of detailed observations. Hence arises, as I have found to my cost, a constant tendency to fill up the wide gaps of knowledge by inaccurate and superficial hypotheses.

But I have too deeply enjoyed the voyage not to recommend any naturalist, although he must not expect to be so fortunate in his companions as I have been, to take all chances, and to start, on travels by land if possible, if otherwise on a long voyage. He may feel assured he will meet with no difficulties or dangers, excepting in rare cases, nearly so bad as he beforehand anticipates. In a moral point of view, the effect ought to be, to teach him good-humoured patience, freedom from selfishness, the habit of acting for himself, and of making the best of every occurrence. In short, he ought to partake of the characteristic qualities of most sailors. Travelling ought also to teach him distrust; but, at the same time, he will discover how many truly kind-hearted people there are with whom he never before had, or ever again will have, any further communication, who yet are ready to offer him the most disinterested assistance.

Note.-The snake, described at page 123, vol. i., with the curious habit of vibrating its tail, is a new species of Trigonoceph. alus, which M. Bibron proposes to call T. crepitans. 


\section{N D E X.}

Abbott, Mr., on spiders, i., 45. Aborigines banished from Van Diemen's Land, ii., 235.

Abrolhos, i., 18. of Australia, ii., 218-239.

Absence of trees in Pampas, i., 58.

Aconcagua, volcano of, i., 325, ii., 32 .

Actinia, stinging species, ii., 258.

Africa, Southern part desert, yet supports large animals, i., 108.

Agouti, habits of, i., 89.

Ague, common in Peru, ii., 129.

Albemarle Island, ii., I43.

Allan, Dr, on Diodon, i., 18.

259.

Alluvium, saliferous, in Peru, ii., 127.

Amblyrhynchus, ii., 155, 168.

Anas, species of, i., 257.

Animaleule, see lnfusoria.

Antarctic Islands, i., 319.

Antipodes, ii., 196.

Ants at Keeling Island, ii., 247.

- in Brazil, i., 44.

Apires, or miners, ii., 96.

Aplysia, i., 8.

Apple-trees, ij., 39.

Aptenodytes demersa, i., 256.

Areas of alternate movements in the

Pacific and Indian Oceans, ii., 279.

Armadilloes, habits of, i., 122.

i., 165,198 .

Arrow-heads, ancient, i., 134, ii. 117.

Ascension, ii., 292.

A spalax, blindness of, i., 66.

Athene, i., 89, 159.

Atolls, ii., 260.

Attagis, i., 121.

Atwater, Mr., on the prairies, i., 152.

Audubon, M., on smelling-power of carrion-hawks, i., 236, $23 \pi$.

Australia, ii., 214.

Australian barrier, ii., 270.

Azara on spiders, i., $45,48$.

- on rain in La Plata, i., 59.

75 .

on range of carrion-hawks, i.,

$$
\text { II.-D D }
$$

Azara on habits of carrion-hawks, i., 72.

- on a thunder-storm, i., 79 .

- on ostrich-eggs, i., 117 .

- on bows and arrows, i., 135.

i., 152 .

i., on great droughts, i., 170.

on hyàrophobia, ii., 113.

Bachman, Mr., on carrion-hawks, i., 237.

Bahia Blanca, i., 97-135.

Bahia, Brazil, i., 14.

--, scenery of, ii., 297.

Balbi on coral reefs, ii., 266.

Bald Head, A ustralia, ii., 239

Ballenar, Chile, ii., 107.

Banda Oriental, i., 49, 181.

Banks's Hill, i., 270.

Barking-bird, ii., 28.

Basaltic platform of Santa Cruz, 3 231.

Bathurst, Australia, ii., 229.

Bat, vampire, i., 27 .

Bay of lslands, New Zealand, ii., 196.

Beads, hill of, i., 190.

Beagle Channel, Tierra del Fuego, i., 280.

Beech-trees, i., 303, ii., 18.

Betles alive in sea, i., 203.

-, dung-feeders, ii., 290, 291.

—_ at St. Julian, i., 218.

- in brackish water, i., 27.

- on a fungus, i., 41 .

Behring's Straits, fossils of, i., 168.

Bell of Quillota, i., 329.

Benchuca, ii., 82.

Berkeley Sound, i., 241.

- Rev.J., on Confervæ, i., 18

Bibron, N1., ii., 150, 155.

Bien-te-veo, i., 69.

Birds of the Gallapagos Archipelago, ii., $146,168$.

Birds, tameness of, ii., 172.

Burgos latro, ji., 256.

Bizcacha, habits of, i., 89, 158.

Blackwall, Mr., on spiders, i., 207. 
Blindness of tucutuco, i., 65.

Body, frozen, i., 113, 320.

Bolabola, is., 264, 270.

Bulas, manner of using, j., 56, 142.

Bombs, volcanic, ii., 295.

Bones of the guanaco collected in certain spots, i., 215.

--., fire made of, i., 250.

---, recent in Pampas, i., 171.

- - , fossil, i., 104, 162, 165, 198,

Bory St. Vincent on frogs, ii., 150.

Boulders, i., 240, 318.

Bramador, E1, ii., 123.

Brazil, great area of granitc, i., 15.

Breaches in coral reefs, ii., 274.

Breakwater of sea-weed, i., 308.

Brewster, Sir D., on a calcareous deposit, i., 12.

Bridge of hide, i., 338.

Brincas, ii., 88, 89, 117.

Buckland, Dr., on fossils, i., 168.

Buenos Ayres, i., 154.

Buffon on American animals, i., 222, 223.

Bug of Pampas, ii., 82.

Buildings, Indian, ii., 116-120, 133.

Bulimus on desert places, ii., 105.

Burchell, Mr., on food of quadrupeds, i., 111.

116.
i., 345 .

Butterflies, flocks of, i., 202, 203

Butterfly producing clicking sound, i., 42 .

Button, Jemmy, i., 266.

Byron's account of fox of Falklands, i., 249.

on an Indian killing his child, i., 2 \%.

Cacti, i., 212, 336, ii., 140.

Cactornis, 1i., 147, 168.

Calasoma on wing out at sea, i., 203.

Calcareous casts of branches and roots of trees at King George's Sound, ii., 240.

Ascension, i., 11.

Callao, ii., 128.

Calodera, i., 159.

Calomys bizcacha, i., 158.

Camarhynchus, ii., 148, 168.

Camelidie, fossil animal allied to, i., 221.

Canjs antarcticus, i., 249.

Canis fulvipes, ii., 17.
Capybira, or carpincho, i., 63, ii., 26.

- - , fossil allied to, i., 105.

Cape Horn, i., 272.

Cape of Good Hope, i., 109.

Caracara, or Carrancha, i., 70, 71.

Cardoon, heds of, J., 153, 189.

Carmichael, Capt., i1., 175, 247.

Carrion-hawks, i., 70, 153, 236.

Casarita, j., 122.

Castro, Chiloe, ii., 13, 34.

Casts of trees, ii., 240.

Casucbas, ii., 89.

Cathartes, i., 75, 237, ii., 22.

Cats run wild, i., 153, it., 294

- good to eat, 1., 149.

- scratch trees, i., 173.

, cruelty to mice, i., 256.

Cattle, effects of their grazing on the vegetation, i., 152.

- killed by great droughts, i., 170,187 .

-

$-\cdots$, curious breed of, i., $185,186$.

-

wild at the Falkland Islands, i., 213-24\%.

Cauquenes, hot springs of, i., 339.

Causes of extinction of species among mammalia, i., 223.

- of discoloured sea, i., 18.

Cavia Patagonica, i, 89.

Cervus campestris, i., 61.

Ceryle Americana, i., 176.

Chacao, Chiloe, ii., 9 .

Chargos atolls, i1., $2 \% 7$.

Chalk-like mud, ii., 259.

Chamisso on drifted seeds and trees, ii., $246,254$.

- on coral reefs, ii., 261.

Changes in vegetation of Painpas, $i$., 153.

ii., 289.

Charles Island, Galapagos Archipelago, ii., 141.

Cheese, salt required for, i., 84 .

Cheucau, ii., 14, 27.

Chile, i., 325, ii., 91 .

$\overline{ }$, features of country, i., 328

Chiloe, ii., 7 .

-

$\longrightarrow$, roads of, ij., 9, 33 .

- inhabitants of, ii., $8,11$.

Chionis, i., 121.

Chonos Archipelago, ii., 18.

313. cliniate of, i.,

ii., 27. 
Chupat, Rio, i., 136.

Cladonia, ii., 126.

Clearness of atmosphere within Andes, in Chile, i., 330.

Climate of Tierra del Fuego and Falkland 1slands, i., 312.

Antarctic Islands, i., 319. Galapagos, ii $, 139,145$.

118,119 .

Clouds of vapour after rain, i., 30 .

- on Corcovado, i., 36. hanging low, ii., 131.

Coleoptera in Tropics, i., 43. ont at sea, i., 203 . of St. Julian, i., 218.

Colias edusa, flocks of, i., 203.

Collnett,Capt., on spawn in sea, i.,22.

ii., 156 .

ii., 165 .

Colonia del Sacramiento, i., 183.

Colorado Rio, i., 89.

Compound animals, i., 258, 259.

Concepcion, Chile, ii., 46.

Condor, habits of, i., 234, 238, 348.

Confervæ, pelagic, i., 18.

Conglomerate on the Ventana, i., 139.

Conurus, i, 176. iu Cordillera, ii., 69.

Convicts of Nauritius, ii., 283.

Wales, ii., 233.

Cook, Capt., on kelp, i., 308.

Copiapó, river and valley of, ii., 108.

C, town of, ii., 114.

Coquimbo, ii., 98.

Coral formations, ij., 1\%, 242-281.

-, stinging species of, ii., 257.

- , dead, ii., 253, $27 \%$.

Corallines, i., 259.

Corcovado, clouds on, i., 36

-_-, volcano, ii., 31 .

Cordillera, appearance of, i., 332, ii., $10,66,6 \%$.

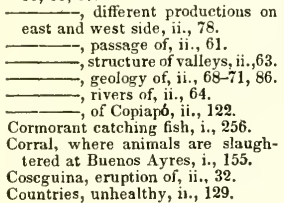

Couthouy, Mr., on coral-reefs, ii., 272.

Crabs, hernit species of, ii., 248. at Keelıng Island, ii., 256. at St. Paul's, i., 13.

Craters, numher of at the Galapagos A rchipelago, ii., 139.

- of Elevation, ii., 284.

Crisia, i., 260.

Cruelty to animals, i., 195.

Crustacea, pelagic, i., 207.

Ctenomys Braziliensis, 1., 64.

- , fossil species of, i., 105.

Cucao, Chiloe, ii., 35.

Cuckoo-like habits of Molothrus, i., 67.

Cuentas, Sierra de, i., 190.

Cumbre of Cordillera, ii., 89.

Cuming, Mr., on shells, ii., 162, 290.

Cuttle-fish, habits of, i., 8, il., 27.

Cuvier on Diodon, i., 17 .

Cynara, i., 152.

Cyttaria Darwinii, i., 303.

Dacelo Iagoensis, i., 2.

Dasypus, three species of, i., 122.

Deer, i., 61, 62, 169.

Degradation of tertiary formations, ii., 101.

Deinornis, ii., 210.

Deserts, ii., 107, 126.

Desmodus i., 27.

Despoblado, valley of, ii., 115.

Dieffenbach on Auckland Island, i., 314 , ii., 220.

Diodon, habits of, i., 16.

Discoloured sea, i., 18.

Diseases from miasma, ii., 129, 219.

Distribution of mamnalia in America, i., $16 \pi$.

sides of Cordillera, ii., 78 .

-

ii., 165.

Dobrizhoffer on ostriches, i., 120.

Docks, imported, ii., 211.

Dogs, shepherd, i., 191.

D'Orligny, Travels in South America, i., 100, 119, 153, 165, 191, 215.

Doris, eggs of, i., 258.

Donbleday, Mr., on a noise made by a butterfly, i., 42 .

Drigg, lightning tubes at, i., 76 .

Droughts, great, in Pampas, i., 169

Dryness of St. Jago, i., 5.

D... of winds in Tierra deI Fuego, i., 298. 
Dryness of air in Cordillera, ii., 77.

Du Bois, ii., 151, 175.

Dung-feeding bectles, ii., 290, 291.

Dust, falling from atmusphere, $j ., 6$.

Earthenware fossil,ii., 136.

Earthquake, accompanicd by an elevation of the coast, ii., 56 . ii., 110.

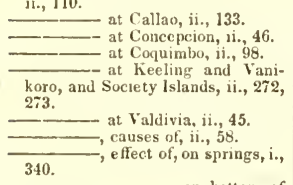
sea, ii., 52. on bottom of $\frac{331}{3}$, ii, 47 . 48, effects of, on sea, ii., 46 , $48,50$.

bed, 1i., 120.

52.

, on S.W. coast, i., 316.
the ground, i., 254 . ji., 54 .

Eggs of Doris, i., 258.

Ehrenberg, Prof, on Atlantic dust, i., 6 .

i. 0 on infusoria in

Pampas, i., 105, 165.

the open sea, i., 208.

Patagonia, i., 219.

Fuegian paint, i., 284.

coral mud, ii., 259.

tuff at Ascension, ii., 296, 297.

- - on phosphorescence of the sea, i., 209.

hill, ii., 123.

Eimeo, view of, ii., 182.

Elater, springing powers of, i., 39.

Electricity of atmosphere within Andes, ii., 77 .

Elephant, weight of, i., 111.
Elevated shells, j., 108, 165, 219, 327. ii., $39,56, \mathrm{~J} 00,134$.

Elevation of coasts of Chile, i, 32\%, ii.. $39,53,56,92,100,118$.

$$
\begin{aligned}
& \text { B. Blanca, i., } 106 . \\
& 137 .
\end{aligned} \text { Patagonia, i., 220, ii., }
$$

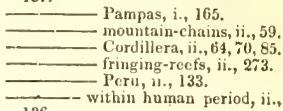

136.

Entomology of the Galapagos Archipelago, 1i., 150, 164, 166.

\begin{tabular}{l}
- Brazil, i., 43, \\
\hline 79. \\
\hline $306,30 \%$.
\end{tabular}

Entre Rios, geology of, i., 164.

Epeira, habits of, i., 46, 48.

Erratic blocks, how transported, i., 317 .

cal countries, i., 319 .

Cruz, i., 240.

i., 317 .

Estancia, value of, j., 185.

Extermination of species and races, i., 224, 1i., 219, 228, 237.

Extinction of shells at St. Helena, ii., 289.

- - of species, causes of,i.,224.

Wales, ii., $219,237$.

Eyes of tucutuco and mole, i., 66 .

Falconer, Dr., on the Sivatherium, i., 187.

- Jesuit, on the Indians, i., 133.

pas, i., 136. , on rivers in Pam, on natural enclosures, i., 149 .

Falkland lslands, i., 241.

172.

$\frac{172 \text { i., } 60,61 .}{\text { i., } 73 .}$, carrion-hawks of, 
Falkland 1slands, wild cattle and horses of, i., 243-247.

- $\ldots$, climate of, i., 312.

Fat, quantity eaten, i., 150 .

Fear an acquired instinct, ii., 175.

Februa, i., 42.

Fenuel, run wild, i., 152.

Ferguson, Dr., on miasma, ii., 130.

Fern-trees, i., 314, ii., 238.

Fernando Noronha, i., 14, ii., 140.

Fields of dead coral, ii., 253.

Fire, art of making, i., 251, ii., 186.

Fish, eating coral, ni., 258.

— of Galapagos, ii., 162.

- emitting harsh sound, i., 174 .

Flamingoes, i., 85 .

Fleas, ii., 102, 103.

Floods after droughts, i., 171. clear after snow, ii., 68.

Flora of the Galapagos, if., 140, 164 , 169.

of Keeling Island, ii., 244.

of St. Helena, ii., 286, 287.

Flustraceæ, i., 258, 309.

Forests, absence of, in La Plata,i.,59. of Tierra del Fuego, i., 271,

313 , ii., 24. of Chiloe, i.,313,ii.,17, 24,33. of Valdivia, ii., 40, 44. of New Zealand, ii., 209,210. of A ustralia, ii., 217.

Fossil Mammalia, i., 104, 162, 165, $198,222$.

-- earthenware, ii., 136.

Fox of the Falkland Islands, i., 249.

-- of Chiloe, ii., 17.

Friendly Archipelago, ii., 280.

Frogs, noises of, i., 37 .

- , bladders of, ii., 153.

- and toads, not found on oceanic islands, ii., 150 .

Frozen soil, 1., 113, 319.

Frust-trees, southern limit of, i., 313.

Fucus gigante us, i., 308 .

Fuegians, i., 262-302.

Fulgurites, i., 76 .

Fungus, edible, i., 303

Furnarius, i., 122 .

Galapagos Archipelago, ii., 138; natural history of, ii., 145 . belongs to American Zoology, ii., 145, 166 .

Gale of wind, i., 279 , ii., 18.

Gallegos River, fossil bones at,i.,215.

Gallinazo, $i_{*}, 71$.

Gauchos, i., 54, 200.

- character of, i., 200.
Gauchos live on meat, i., 150.

Gay, M., on floating islands, $i ., 342$. i., 26 .

Geese at the Falkland Islands, i.,257.

Geographical distribution of American animals, i., 167, ii., 78 .

ii 150 .

na of Galapagos, $\mathrm{ii}, 165$.

of frogs, of Fau-

Geology of Cordillera, ii., 68,86 .

- of Patagonia, i., 219, 233.

- of St. Jago, i., 7.

of St, Paul, i., 10.

of B. Blanca, i., 104.

of Pampas, i., 164.

of Brazil, i., 15.

Georgia, climate of, i., 320 .

Geospiza, ii., 14\%, 168 .

Gill, Mr., ou an upheaved river-bed, ii., 120.

Gillies, Dr., on the Cordillera, ii., 73.

Glaciers in Tierra del Fuego, i., 289, 316.

- in Cordillera, ii., 75.

Glow-worms, i., 38 .

Goats, destructive to vegetation at

St. Helena, ii., 289.

-, bones of, i. 215.

Goitre, ii., 61.

Gold-washing, i, 343.

Good Success Bay, i., 262.

Gossamer spider, i., 204.

Gould, Mr., on the Calodera, i., 159.

ii., 146.

Granite mountains, Tres Montes, i., 21.

Graspus, i., 13.

Gravel, how far transported, i., 138

- of Patagonia, i., 96, 219.

Greenstone, fragments of, i., 331 .

Gryllus migratorius, it., 82.

Guanaco, habits of, i., 213-215.

- , fossil allied genus, i., 221.

Guantajaya, mines of, ii., 126.

Guardia del Monte, i., 151 .

Guasco, ii., 106.

Guasos of Chile, i, 332.

Guava, imported into Tahiti, ii., 178.

Guinea-fowl, i., 4, ji., 294.

Gunnera scabra, if., 16 .

Gypsun, great bells of, ii., 68.

- in salt-lake, i., 83.

- in Patagonian tertiary-

beds, j,, 219. 
Gypsum at Iquique with salt, ii., 127. at Lima witl shells, ii., 134

Flachette, M., on lightning-tubes, i., 77.

Hailstorm, i., 147.

Hall, Capt., Basil, on terraces of Coquimbo, 1i., 99.

Hare, Varying, i., 58.

Ilead, Capt., on thistle-beds, i., I52, 157.

Height of snow-line on Cordillera, $i$., 315.

Henslow, Prof,, on potatoes, ii., 23. Island, ii., 245

IJeruit crabs, ii., 248.

Hill, emitting a nuse, ii., 123.

Ilinıantopus, i., 146.

Hugoleu barrier-reef, ii., 265.

Iloles made by a bird, 1., 122 .

Holman on drifted seeds, ii., 245.

Holuthurie feeding on coral, il., 259.

IIooker, Sir J, on the Cardoon,i.,152.

-, Dr. J. D., on the Kelp,i.,307.

plants, ii., 164, $165,169$.

Horn, Cape, i., 272.

Horner, Mr., on a calcareous deposit, i., 12 .

Horse-fly, i., 218.

Horses difficult to drive, i., 141. 152. $1 \% 0$.

killed by great droughts, i.,

170. multiplication of, i., 299.

broken in, j., 193.

Horse, powers of swimming of, i., 182.

wild at the Falkland Islands, i., 245.

- fossil, i., 104, 165.

Horscinanship of the Gauchos, i., $195,251$.

Hot springs of Canquenes, i., 339 .

Huacas, ii., 133, 135.

Humboldt on burnished roeks, i., 16.

- on the atmosphere in tropjes, i., 40.

on frozen soil, i., 113.

- on hybernation, i., 125.

___ on potatoes, ji., 23.

ii., 110 , on earthquakes and rain,

-

IIumming-birds of Rio de Janeiro, i., 40.

of Chile, i., 350.

Hybernation of animals, j., 125.
IIydrochærus capybara, i., 63.

$11 y$ drophobia, ii., 113.

Hyla, i., 37 .

llymenophallus, i., 41.

Jackson, Col., on frozen snow, ii., 75 .

Jaguar, habits of, i., 172.

Jajuel, mines of, i., 334 .

James Island, Galapagos Archipelago, ii., 143 .

Juan Fernandez, volcano of, ii., $5 \pi$.

-, flora of, ii., 165.

lbis melanops, i., 212.

lce, prismatic structure of, ii., 75 .

lcebergs, i., 240, 289, 316-324.

Incas' bridge, ii., 88, 117.

Incrustations on coast rocks, i., 12, 16.

Indian fossil remains, ii., 135 .

Indians, attacks of, i., 81, 98, 164.

-., Patagunans, i., 298.

--, Araucarians, ii., 42.

$\longrightarrow$ of the Pampas, i., 129.

- of Valdıvia, ii., 42.

345. perforated stones used by, $i$. ,

- powers of tracking, ii., 79 .

, grave of, i., 217, 240.

-, ruins of houses of, in Cordillera, ii., 116, 133.

$\longrightarrow$, antiquities of, in La Plata, i., $58,134$.

-, decrease in numbers, i., 133.

Infection, i1., 220.

Infusoria in dust in the Atlantic, i., 6.

- in the sea, 1., 18, 208.

- in Pampas, i., 105, 165.

- in Patagonia, i., 219.

- in white paint, i., 284.

- in coral mud, ii., 259.

- at Ascension, ii., 297.

Insects, first colonists of St. Paul's rocks, i., 13.

- blown ont to sea, i., 204.

of Patagona, 1., 218, ii , 79.

$30 \%$.

169. of Galapagos, ii., 150, 164,

of Keeling Island, ii., 247.

- of St. Heleua, ii., $290,291$.

Instincts of birds, j., 122, ii., 172.

lodine with salt at lquique, ii., 128.

Iquique, ii., 124.

lron, oxide of, on rocks, i., 16.

lslands, vceanıc, volcanic, i., 10

- floating, i., 342.

-, Antarctic, i., 319 .

low, ii., 17\%, 262. 
Kater's peak, i., 272.

Kauri pine, 1i., 209, 210.

Keeling lsland, ii., 242.

$$
2 \tau 2 \text {. }
$$

247.

\begin{tabular}{l}
$2 \tau 2$. \\
\hline $24 \%$
\end{tabular}

Kelp, or sea-weed, i., 307.

Kendall, Lieut., on a frozen body, i., 320.

Kingfishers, i., 2, 176.

King George's Sound, ii., 239.

Lahonrers, condition of, in Chile, 3., 344.

Lagoon-islauds, ii., 170, 243, 260.

Lagostomus, i., 158.

Lake, brackish, near Rio, i., 26.

- with floating islands, i., 342. 136. formed during earthquake, ii.,

Lanarck on acquired blindness, i.,66.

Lampyris, i., $3 \pi$.

L ancaster, Capt., on a sea-tree,i., 128.

Land-shells, ii., 105, 288, 289, 290.

Lazo, i., 56, 196, 243.

Leaves, fall of, i., 302.

L-, fossil, ii., 23\%.

Leeks in New Zealand, imported, ii , 211.

Lepns Magellanicns, i., 248.

I.esson, M., on the scissor-beak, i., 176.

lands, i., 248.

Lichen on loose sand, ii., 126.

Lichtenstein on ostriches, i., 117 .

Lightning storms, i., 79.

- tubes, i., 76 .

Lima, ii., 128, 132.

$\longrightarrow$, elevation of a river near,ii.,119.

Lime, ehanged by lava into crystalline rock, i., 7 .

limuæa in brackish water, i., 26.

Iion-ant, ii., 229.

Lizard, 1., 125.

- , marme species of, ii., 155.

Lizards, transport of, ii., 151.

Llama or Guanaco, habits of, i., 213215.

Loensts, ji., 81 .

Longevity of species in Mollusca, 1., 106.

Lorenzo, San, island of, ii., 134.

Low Archipelago, ii., 177.

Lund, M, , on antiquity of man, ii., 119.
Lund and Clausen on tossils of Braz11, i., 166, 222 .

Luxan, 1i., 81.

Luxuriant vegetation not necessary to support large animals, i., 108.

Lycosa, i., 45.

Lyell, Mr., on terraces of Coquimbo, i1., 99.

i., 106.

1., 106 . cific, ii., $263,264$.

-, on change in vegetation, i , 153 .

1, 153 , , on fossil horses' teeth, i., 166. mals, ii., 78 .

mals, il., 78 , on frozen snow, ii., 75 .

ice-period, i., 223. i., 203 .
earthquakes, ii., 54 .

MacCulloch on infection, ii., 220 .

Macquarie river, ii., 230.

Macrauchenia, i., 104, 221.

Macrocystis, i., $30 \%$.

Madrina, or godmother of a troop of mules, ii., 62.

Magdalen Channel, i., 310.

Magellan, Strait of, i., 297.

Malcolmson, Dr., on hail, i., 148.

Maldiva atolls, ii., 261, 273, 276.

Maldonado, i., 49.

Mammalıa, fossil, i., 104, 162, 165, 198,222 , ii., 137.

Man, antiquity of, ii., 119.

Man, fossil remains of, ii., 135.

—

_- fear of, an acquired instinct, ii., 175.

-, extinction of races, ii., 219, 237.

Mares killed for their hides, i., 197 .

Mare's flesh eaten by troops, i, 130.

Mastodon, i., 162, 165.

IIatter, granular, movements in, i., 128.

Mauritius, ii., 281.

Maypu River, ii., 64.

Megalonyx, i., 104, 167.

Megatherıum, i., 104, 106, 167.

Mendoza, climate of, ii., 74 .

- $, \mathrm{ii}_{2}, 83$.

Mexico, elevation of, i., 168.

Miasmata, ii., 128, 220.

Mice inhabit sterile places, ii, 121. 
Mice, number of, in America, i., 62.

$\longrightarrow$, how transported, ii., 27, 146.

- different on opposite sides of Andes, ii., 78 .

- of the Galapagos, ii., 146.

- of Ascensiont, ii., 294.

Millepora, ii., 257.

Mills for grinding ores, i., 343.

Mumosie, i., 32.

Mimus, i., 69, ii., 168, 173.

Miners, condition of, i., 336, 342, ii., $94,103$.

Mmes, i., 335, ii., 95, 103.

--, how discovered, ii., 66.

Missionaries at New Zealand, ii.,20\%.

Mitchell, Sir T., on valleys of Australia, il., 224.

Mocking-bird, i., 69, ii.. I68, 173.

Molina, omits description of certain birds, i., 350.

Molothrus, habits of, i., 66 .

Monkeys with prehensile tails, i., 35.

Monte Vıdeo, i., 50, 181.

Moresby, Capt.,on a great crab,ii.,257. $2 \pi \%$.

Mount Sarmiento, i., 300, 310.

- Tarn, i., 301 .

Mountains, elevation of, ii., 59.

Movements in granularmatter,i,,128.

Mud, chalk-lıke, ti., 259.

dist urbed by earthquake, ii.,52.

Mules, ii., 62.

Muniz, Sig,, on niata cattle, i., 186.

Murray, Mr., on spiders, i., 206.

Mylodon, i., 104, 167, 198.

Myopotamus Coipus, ii., 26.

Negress with goitre, ii., 61 .

Negro, Rio, i., 80, 190.

lieutenant, i., 96.

New Caledonia, reef of, ii., 265, 26\%, $2 \tau 5$.

- Zealand, ii., 196.

Niata cattle, i., 185, 186.

Noises from a hill, ii., I23.

Noses, ceremony of pressing, ii., 204, 205.

Nothura, i., 57.

Notopod, crustacean, i., $20 \%$.

Nulliporæ, incrustations like, i., 11. 302.

Octopus, habits of, i., 8 .

Oily coating on sea, i., 22.

Olfersia, i., 13.

Opetiorhynchus, ii., 28.

Opuntia Galapageia, ii., 140.
Opuntia Darwinii, i., 212.

$\longrightarrow$, i., 336.

Orange-trees, self-sown, i., 154.

Ores, gold, i., 343.

Ornithorhynchus, ii., 228.

Ornithology of Galapagos, ii., 146, 168.

Osorno, volcano of, P., 8, 10, 31 .

Ostrich, habits of, i., $54,114$.

Ostrich's eggs, i., 144.

Otaheite, ii., 177 .

Otter, ii., 26.

Ova in sea, i., 21.

Oven-bird, i., 121.

Owen, (apt., on a drought in Africa, i., 169 .

---, Professor, on the Capybara, j., 63 .

peds, i., 104-107, 166.

Gallinazo, i., 237.

Owl of Pampas, i., 89, 159.

Oxyurus, i., 305, ii., 28.

Oysters, gigantic, i., 219.

Paint, white, i., 284.

Pallas on Siberia, i., 85.

Palm-trees in La Plata, i., 59.

- in Chile, i., 329, 330.

$\longrightarrow$, south limit of, i., 314.

Palms absent at Galapagos, ii., 142.

Pampas, number of embedded remains in, i., 199.

- $\mathrm{S}$. limit of, i., 95.

-_, changes in, i., 153.

183. not quite level, i., 157, 161,

- geology of, i., 164, 199.

ii., 79. view, of, from the Andes,

Papilio feronia, i., 42.

Parana, Rio, i., I60, 1\%7, 188.

- _-, islands in, i., 171 .

Parish, Sir W., on the great drought, i., 170.

Park, Mungo, on eating salt, i., 141.

Parrots, i., 176, 315.

Partridges, i., 57.

Pas, fortresses of New Zealand, ii., 198.

Passes in Cordillera, ii., 88.

Pasture, altered from grazing of cattle, i., 152.

Patagones, i., 82.

Patagonia, geology of, i., 219, ii., 81. 230.

Patagonian Indians, i., 298. 
Peach-trees self sown, i., 154.

Peat, formation of, ji., 25.

Pebbles perforated, i., 190, 345. ii., 254.

Pelagic animals in southern ocean, i., $20 \%$.

Penas, Gulf of, i., 318.

Penguin, habits of, i., 256.

Pepsis, habits of, i., 45.

Pernambuco, reef of, ii., 301, 302.

Pernety on hill of ruins, i., 252.

- on tame birds, ii., 174.

Peru, ii., 124-137.

$\longrightarrow$, dry valleys of, ii., 119, 124.

Petrels, habits of, ii., 29.

Peuquenes, pass of, ii., 68.

Phonolite at F. Noronha, i., 14.

Phosphorescence of the sea, i., 208.

260.

of land insects and

sea animals, i., 37, 38 .

Phryniscus, i., 124.

Pine of New Zealand, it., 209, 210.

Plains at foot of Andes in Chile, i., 338 , ii., 63 .

__ almost horizonta] near St. Fé, i., 161 .

เanariæ, terrestrial species of, i., 33 .

Plants of the Galapagos, ii., 140, 164, 169.

-

-.. of St. Helena, ii., 287.

-- fossil in Australia, ii., 237.

Plata, Rio, i., 49.

—— , thunderstorms of, i., 79.

Plover, long-legged, i., 146.

Polished rocks, Brazil, j., 16.

Polyborus chimango, i., 73 .

- - Novæ Zelandiæ, i., 73. Braziliensis, i., 70 .

Ponsonby Sound, i., 285.

Porpoises, i., 49.

Port Desire, i., 211.

, river of, i., 136, 215.

St. Julian, i., 218.

Famine, i., 300.

Portillo pass, ii., 68, 76 .

Porto Praya, i., 1.

Potato, wild, ii., 23.

Potrero Seco, ii., 108.

Pricies, vegetation of, i., 152.

Prevast, M., on cuckoos, i., 68.

Priestley, Dr., on lightuing-tubes, i., 76 .

Procellaria gigantea, habits of, ii.,29.

Proctotretus, i., 125.

Proteus, blindness of, i., 66 .

$$
11-91
$$

Protococcus nivalis, ii., 73 .

Pteroptochos, two species of, i., 348 .

, species of, ii.,I4, 27,28.

Puente del Inca, ii., 88, 117 .

Puffinus cinereus, ii., 29.

Puffinuria Bermardii, ii., 30.

Puma, habits of, i., 173, 235, 347.

$\longrightarrow$, flesh of, i, 149.

Puna, or short respiration, ii., 71 .

Punta Alta, Bahia Blanca, i., I04.

- - Gorda, i., 165, ii., 116.

Pyrophorus luminosus, i., 38.

Quadrupeds, fossil, i., 104, 162, 165, 198, 222.

- large, da not require luxuriant vegetation, i., 108.

Quart -, weight of, i.,111.

Quartz of the Ventana, i., 139.

of Tapalguen, i., 148.

$\longrightarrow$ of Falkland Island, j., 252.

Quedius, i., 13.

Quillota, valley of, i., 327.

Quintero, i., 32\%.

Quiriquina 1sland, ii., 46.

Quoy and Grimard on stinging corals, ii., 258.

274. on coral-reefs, ii.,

Rabbit, wild, at the Falkland Islands, i., 248.

Rain at Coquimbo, ii., 92, 104, 106.

- at Rio, i., 36.

— and earthquakes, ii., 110.

- in Pert, ii., 127, 128.

- in Chile, formerly more abundant, ii., 118.

ii., 93.

Rani Mascariensis, ii., 151.

Rat, only aboriginal animal of New Zealand, ii., 210.

Rats at Galapagos, ii., 146.

— at Ascension, ii., 294.

- at Keeling Island, ii., 247.

Rattle-snake, species with allied halit, i., 123.

Red snow, ii., 73 .

Reduvius, ii., 82.

Reef at Pernambuco of sandstone, ii., $301,302$.

Reefs of coral, ii., 260-281.

--, Barrier, ii., 264, 274.

--, Fringing, ii., 268.

Reeks, Mr., analysis of salt, i., 83. bones, i., I98.

ii, 135. salt and shells, 
Remains, human elevated, ii., 135.

Remedies of the Gauchos, i., 163.

Rengger on the horse, i., 299.

Reptiles absent in Tierra del Fuego i., 306 .

Respiration diflicult in Andes, ii., $\approx 2$.

Retrospect, i., 65.

Revolutions at Buenos Ayres, i., 179. $\mathrm{R}$ hinoceroses live in desert coun. tries, i., 109.

(tres, i., frozen, i., 114, 322.

Rhyochons nigra, i., 1\%4.

Richardson, Dr., on mice of North America, ii., 146.

\begin{tabular}{l} 
i., 324 . \\
$113,320$. \\
\hline
\end{tabular} 150.

distribution, i., 166 geogruphical

Rimsky atoll, ii., 261.

R1o de Janeiro, i., 23.

- Plata, i., 49.

-- Negro, i., 80, 190.

- Colorado, i., 89.

- S. Cruz, i., $22 \%$.

-- Sauce, i., 136.

- Sulado, i., 151.

Rivers, power of, in wearing channels, i., 233, ii., 69 .

River-bed, arched, ii., 120.

River-courses dry in America, i., 13 .

Rocks burnished with ferruginous matter, i., 16.

Rulents, number of in America, i., 62,230 .

-., fossil species of, i., 104.

Rosas, General, i., 90, 132, 179.

Ruins of Callao, ii., 133 .

- of Indian buildings in Cordil-

lera, ii., 116, 133.

S. Cruz, i., 22\%.

Salado, Rio, i., 151

Salinas at the Galapagos Archipelago, ii., 144 .

in Patagonia, i., 83, 218.

Saline efflorescences, i, $99,100$.

Salt with vegetable food, i., 141 .

-.-, superficial crust of, ii., 127.

-.-, with elevated shells, ii., 134.

Salt-lakes, i., 83, 218 , ii., 144.

Sandwich Archipelago, no frogs at, ii., 151 .

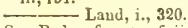

San Pedro, forests of, ii., 17,
Sand-dunes, i., 96.

Sand, hot from sun's rays, at Galapagos Archupelago, ii., 145.

-- , noise from friction of, ii., 123.

Sandstone of New South Wales, ii., $222,223$.

$\longrightarrow$, reef of, ii., 301, 302.

Santa Cruz, river of, i., $22 \%$.

Santiago, Chile, i., 338.

Sarmiento, Mount, i., 300, 310.

Sauce, Rio, i., 136.

Saurophagus sulphureus, i., 68.

Searus eating corals, ii., 258.

Scelidotherium, i., 104.

Scenery of Andes, ii., 67.

Scissor-tail, i., 177.

Scissor-beak, habits of, i., $1 \% 4$.

Scorpions, canuibals, i., 212.

Scoresby, Mr., on effects of snow on rocks, ii., 67 .

Scrope, Mr., on earthquakes, ii., 111.

Seytalopus fuscus, i., 305, ii., 29.

Sea, open, inhabitants of, i., 208.

-.., phosphorescence of, i., 208.

--, distant noise of, ii., 37 .

Sea-pen, habits of, i., 127, 260.

Sea-weed, growth of, i., 308 .

Seals, number of, ii., 22.

Seeds transported by sea, ii., 165,24 J.

Serpule, protecting reef, ii., 302

Shark killed by Diodun, i., 18.

Shaw, Dr., on lion's flesh, i., 149

Sheep, infeeted, ii., 221.

Shelley, lines on Mont Blanc, i., 216.

Sliells, land, in great numbers, ii., 105.

289.

Shells, fossil, of Cordillera, ii., 70 .

of Galapagos, ii., 162.

- elevated, i., $106,165,220$, $32 \%$, ii., $100,134$.

i., 313 .

i., decomposition of, with salt, ii., 134.

Shepherd's dogs, i., 191.

Shingle-bed of Patagonia, i., 96, 219.

Siberia compared with Patagonia, i., 85.

- zoology of, related to North America, i., 168.

Siberian animals, how preserved in ice, i., 322.

ring their existence, $i,, 113$.

Silicified trees, ii., 86, 112 .

Silurian formations at Falkland Is?. ands, i., 252. 
Silurus, habits of, 1., 174 .

Skunks, i., 103.

Slavery, i., 24, 30, ii., 302.

Snake, venomous, i., 123.

Snow-line on Cordillera, i., 315.

Snow, effects of on rocks, ii., 67 .

- prismatic structure of, ii., 75 . , red, ii., 73 .

Society, state of, in La Plata, i., 52.

-, state of, in Australia, ii.,231.

- Archipelago, ii., 177.

Soda, nitrate of, ii., 125.

-., sulphate of, i., 100.

Soil, frozen, i., 113, 319.

Spawn on surface of sea, i., 21.

Species, distribution of, i., $16 \%$.

- , extinction of, i., 224.

Spiders, habits of, i., 45-48.

-, gossamer, i., 204.

- - on Keeling lsland, ii., 247.

- on St. Paul's, i., 13.

Springs, hot, i., 339.

Stinging animals, ii., 285.

St. Helena, ii., 285.

- Fè, i., 164.

- Jago, Chile, i., 338.

- Maria, elevated, ii., 53, 56.

- Paul's rocks, i., 10.

Stones, perforated, i., 190, 345.

- transported in roots, ii., 254.

Storm, i., 279, ii., 18.

- in Cordillera, ii., 74, 122.

Streams of stones at Falkland Islands, i., 253.

Strongylus, i., 41.

Struthio Rhea, i., 54, 114.

Darwinii, i., 119.

Strzelecki, Count, ii., 237 .

Suadiva atoll, ii., 261.

Subsidence of coral reefs, i., 262-281. of Keeling Island, ii., 272 . of Patagonia, i., 221. of coast of Peru, ii., 133. of Cordillera, ii., 70, 86 . of coasts of Chile, ii., 101 . of Vanikoro, ii., 272 .

Sulphate of lime, i., 81, 219, ji., 134. Swainson, Mr., on cuckoos, i., 67 . Sydney, ii., 215.

Tabanus, i., 218.

Tahiti (Otaheite), ii., 17\%.

Talcabuano, ii., 46.

Tambillos, Ruinas de, ii., 116.

Tameness of birds, ii., 172.

Tapacolo and Turco, i., 348, 349.

Tarn, Mount, i., 301.

Tasmania, ii., 235.

Tattooing, ii., 179, 180, 208, 209.
Temperance of the Tahitians, ii.,189.

Temperature of Tierra del Fuego and Falkland lslands, i., 312. of Galapagos, ii., 139.

Tercero, Rio, fossils, i., 162 .

Terraces of Cordillera, ii., 63. of Coquimbo, ii., 99. of Patagonia, i., 220, 232.

Tertiary formations of the Pampas, i., 104, 164, 199.

$\frac{219, \text { ii., } 81 .}{\text { of, ii., 101. }}$ in Chile, epochs

Teru-tero, habits of, i., 146.

Testudo, habits of, ii., $151,166,16 \%$.

Theory of lagoon-islands, ii., 269.

Theristicus, 1., 212.

Thistle-beds, i., 153, 157, 189.

Thuuder-storms, i., 79.

Tierra del Fuego, i., 262-324.

tation of, i., 312 .

306,307 .

Tinamus rufescens, i., 144.

Tınochorus Eschscholtzii, i., 120.

Toad, habits of, i., 124.

Torrents in Cordillera, ji., 64, 71 .

Tortoise, habits of, ii., 151, 166, 167 .

Toxodon, i., 105, 162, 165, 198.

Transparency of air in Andes, ii., 77.

Transport of seeds, ii, , 165, 245. of boulders, i., 240,318 . of stones, ii., 254 . of fragments of rock on

banks of the St. Cruz River, 1., 233.

Travertin with leaves of trees, Van

Diemen's Land, ii., 23\%.

Tree-ferns, southern limits of, i., 314.

ii, 238.

Trees, absence of, in Pampas, i., 58.

—..., silicified, vertical, ii., 85 .

—_, size of, ii., 112.

--., time required to rot, ii., 45.

Tres Montes, ii., 19.

Trichodesmium, i., 18.

Trigonocephalus, i, 123.

Tristan d'Acunha, ii., 175, 247.

Trochilus, i., 350 .

Tropical scenery, ii., $29 \%$.

Tschudi, M., on subsidence, ii., 134.

Tubes, siliceous, formed by lightning, i., 76 .

Tucutuco, habits of, i., 64.

Tuff, craters of, ii., 139. 
Tuff, infusoria in, ii., 297.

Tupungato, volcano of, $\mathrm{ii}, \mathrm{F}$.

Turco, El, i., 348.

Turkey buzzard, i., 74, 237, ii., 22.

Turtle, manner of catching, ii., 251.

Type of organization in Galapagos lslands, Ainerican, ii., 166 .

Types of organization in different countries, constant, i., 222.

Tyranuas, i., 177.

Ulloz on liydrophobia, ii., 113. on Indian buildings, ii., 118.

Unanùe, Dr., on hydrophobia, ii.,113. Uruguay, Rio, i., 177, 187.

Bizcacha, i., 158.

Uspallata range and pass, ii., 84.

Vacas, Rio, ii., 87.

Valdivia, ii., 39.

- forests of, ii., 40, 44.

Valley of St. Cruz, how excavated, i., 233.

, dry, at Copiapo, ii., 115.

Valleys, excavation of, in Chile, ii., 63,115 .

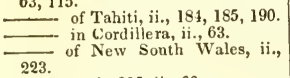

Valparaiso, i., 325, ii., 60.

Vampire bat, i., 27 .

Vapour from forests, i., 30.

Van Diemen's Land, ii., 234.

Vanellus Cayanus, i., 146.

Vanessa, flocks of, j., 203.

Vanikoro, ii., 265, 266, 272.

Ventana, Sierra, i., 137 .

Verbena melindres, i., 51 .

Villa Vicencio, ii., 84 .

Virgularia Patagonica, i., 127, 260.

Volcanic bombs, ii., 295.

islands, i., 10.

phenomena, ij., 58.

Volcanoes near Chiloe, ii., 8, 10, 31 .

- their presence determinea

by elevation or subsidence, ii., 279.

Vultur aura, i., 74, 237, ii., 22.

Waimate, New Zealand, ii., 202.
Walckenaer on spiders, i., 48.

Walleechn-tree, i., 87 .

Water-hog, i., 63 .

Water, sold at Iquique, ii., 125.

Watesh, floating on salt, i., 50 .

Waves, caused by fall of ice, i., 289. from earthquakes, ii., 50,54 .

Weather, connection with earthquakes, ii., 110.

Weatherboard, N.S. Wales, ii., 222.

Weeds in New Zealand, imported, ii., $165,211$.

Weight of quadrupeds, i., 111.

Wellington, Mount, ii., 238.

Wells, ebbing and flowing, ii., 249.

- at lquique, ii., 127 .

West Indies, banks of, ii., 226 . , coral reefs of, ii., 269. -, zoology of, i., 168.

Whales, oil from, i., 22.

leaping ont of water, i., 288.

White, Mr., on spiders, i., 45.

Wigwams of Fuegians, i., 272, 273.

Williams, Rev. J., on infectious disorders, ii., 220.

Winds, dry, in Tierra del Fuego, i., 298.

298. at the Cape Verds, i., 4.

—, cold, on Cordillera, ii., 122.

- on Cordillera, ii., 73.

Winter's Bark, i., 303, ii., 17.

Wolf at the Falklands, i., 249.

Wood, Capt., on the Agouti, i., 89.

Woollya, i., 285.

Yaquil, i., 342.

Yeso, Valle del, ii., 68.

York, Minster, i., 266.

Zonotrichia, i., 67.

Zoological provinces of $\mathbf{N}$. and $\mathbf{S}$.

America, i., 167.

Zoology of Galapagos, ii., 145.

-

— of Tierra del Fuego, i., 304.

of Chonos Islands, i., 26 .

- of St. Helena, ii., 290, 291.

Zoophytes, i., 127.

$258,259$.

Zorillo, or skunk, i., 103. 


\section{VALUABLE B00KS 0F TRAVEL}

PUBLISHED BY

\section{IIARPER \& BROTIIERS, NEW-YORK.}

\section{I.}

\section{DR, DURBIN'S OBSERVATIONS IN THE EAST.}

Observations in the East, chiefly in Egypt, the Desert, Palestine, Syria, Asia Minor, and Constantinople. By John P. Durbin, D.D. 2 vols. 12mo. Engravings. Muslin gilt. $\$ 200$.

It is a most rich, intellectual feast.-Buffalo Advocate.

The volumes are, without exaggeration, equal in interest and graphic effect to the best books of modern travel with which we are acquainted. There is an off-hand frankness and spirit about the sketches, which are always marked by cantion and discrimination, so that the statements are as reliable as they are attractively interesting.-Spirit of the Times.

Th1s book is curious, attractive, and instructive ; the author has avoided all uselcss lumber, and recorded in simple, nnaffected language, his observations ppon what met his eye. His book shows the scholar, the Christian, the philosophical observer, and the American patriot, but not a bit of the pedant or the bore; a more agreeable companion or guide could scarcely be found than Dr. Durbin.-Buffalo Com. Advertiser.

\section{II.}

\section{DR. DURBIN'S OBSERVATIONS IN EUROPE.}

Observations in Europe, principally in France and Great Britain. By John P. Durbin, D.D. 2 vols. 12mo. Engravings. Muslin gilt. \$200.

Few productions of the kind have been published of late years, in v/hich so many valuable truths have been set forth in so attractive a form.-Afethodist Quarterly Review.

III.

\section{DR, OLIN'S TRAVELS IN THE HOLY LAND, \&C.}

Travels in Egypt, Arabia Petræa, and the Holy Land. By Stephen Olin, D.D. 2 vols. $12 \mathrm{mo}$. Engravings. Eighth Edition. Muslin gilt. \$2 50 .

Dr. Olin's excellent volumes convey a great amount of information, also remarkably accurate ; his volume contains the best account of Egypt that has appeared in this country - perhaps in the langnage.-Dr. DURBIN.

This work, from the pen of the distinguished President of the Wesleyan University, is among the latest on the subject. It is rich in information, pervaded by a lofty spirit, and entitled to entire confidence.-Dr. POTTER's Hond-book.

We can most confidently and cordially recommend this book to our readers, as a production which does honour to the author.-Methodist Quarterly Review. 
IV.

\section{DR, WOLFF'S MISSION TO BOKHARA.}

Narrative of a Mission to Bokhara, in the Years 18431845 , to ascertain the Fate of Colonel Stoddart and Captain Conolly. By Rev. Joseph Wolff, D.D., LL.D. 8vo. Engravings. Muslin gilt. $\$ 200$.

This is a most interesting and instructive*work, containing a sketch of the distinguished author's life, and a rich treasury of Oriental missionary information, interspersed with incidents of thrilling interest. The community are alrealy familiar with the name of the Rev. Joseph Wolff, one of the most remarkable men of the present age--Christian Intel.

A work of great interest, and full of the most curious information and thrilling details. It will be seen to be the work of an eccentric man, but even this rather adds to its interest thandetracts from it.-Albany Spectator.

V.

\section{HUMBOLDT'S COSMOS.}

Cosmos: a General Survey of the Physical Phenomena of the Universe. By Alexander Von Humboldt. From the Fourth German Edition. 8vo. Muslin gilt. To be completed in Four Numbers. Two now published.

The work contains the latest results of the sciences and the last conclusions drawn from them upon the mind and understanding of a great philosopher. 'The work is one of the finest and most finished blossoms which the caltivation of natural sciences has ever produced.-Broadvay Journal.

This work, therefore, will be henceforth the text-book of all who would learn how nature has herself unfolded the story of her birth, and how those sle nourished by her truths have recorded what she taught.-London Critic.

VI.

\section{TRAVELS OF ALEXANDER VON HUMBOLDT.}

Travels and Researches of Alexander Von Humboldt ; being a condensed Narrative of his Journeys in the Equinoctial Regions of America, and in Asiatic Russia ; together with Analyses of his more important Investigations. By W. Macgillivray, A.M. $18 \mathrm{mo}$. Engravings. 45 cents.

Humboldt is the most illustrious traveller of his day. Nothing seems too vast, too varied, too wonderful, or too minute for the keen eye, penetrating intellect, and unwearied exertions of this extraordinary man. A botanist, zoologist, statist, and philosopher, the genius of this great writer seems to have been peculiarly fitted for surveying the varietics and immensity of the physical world ; and he accordingly takes the foremost rank of all travellers, dead or living.-Dibden.

This work has been justly called by a competent judge, " a work of gigantic extent and richness, to which the modern literature of Europe can hardly offer a parallel."-Encyclopadia Americana. 
VIl.

\section{TRAVELS OF MARCO POLO.}

Travels of Mareo Polo, greatly amended and enlarged from valuable early Manuscripts recently published by the French Society of Geography, and in Italy by Count Baldelli Boni. With copious Notes, illustrating the Routes and Observations of the Author, and comparing them with those of more recent Travellers. By Hugh Murray, P.R.S.E. 18mo. Two Maps and a Vignette. Muslin gilt. 45 cents.

Thr best edition of the travels of Marco Polo that we have ever seen. This famons old traveller, after so long labouring under a cloud of suspicion as to the verity of his statements, has lately, by the industry of modern commentators, been rubbed bright, in some degree, and his narratives, always interesting, are now read with a degree of faith which hitherto was not exercised in their perusal. The volume before us contains maps, copious notes, and illustrations by the editor, and is every way a most interesting buok.-Post.

A work hitherto inaccessible, though much renowned in the world of letters. This is another of the great literary performances that originated within the walls of a dungeon, Marcu Polo being, at the time of its composition, imprisoned at Pisa. This enterprising traveller explored nore in the very heart of the Chinese Empire, and acquired more intimate knowledge of the wandering Tartars of Asia, than any of his predecessors, and, indeed, we might add, his successors, for in the 13 th century he enjoyed the immunity, since denied, of visiting Pekin with his eyes open; his description, therefore, cannot but be interesting and valuable, - New-York Commercial Advertiser.

VIII.

\section{DR, PARROT'S JOURNEY TO MOUNT ARARAT,}

Journey to Mount Ararat. By Dr. Friedrich Parrot. Translated by W. D. Cooley. 18mo. Map and Engravingś. Muslin gilt. 50 cents.

This book is a desideratum in English literature. There is a popular interest attached to the mountain, which the traditions both of Christian and Mohammedan nations associate with one of the most impressive events in the earlicst records of our race.-London Spectator,

IX.

\section{BUCKINGHAM'S TRAVELS IN AMERICA,}

America: Historical, Statistical, and Descriptive. By J. S. Buckingham. 2 vols. 8 vo. Engravings. Muslin gilt. $\$ 350$.

"A work of great value, as comprising a vast amount of curious stav tistical information, criticisms on art," \&c. 
$\mathrm{X}$.

\section{GENERAL GREEN'S TEXIAN EXPEDITION AGAINST MIER.}

Journal of the Texian Expedition against Mier; subsequent Imprisonment of the Author; his Sufferings, and final Escape from the Castle of Perote, with Reflections upon the present Political and probable future Relations of Texas, Mexico, and the United States. By General Thomas J. Green. Illustrated by Drawings taken from Life by Charles M'Laughlin, a Fellow-prisoner. 8vo. Muslin gilt. \$200.

This work is one of startling and most absorbing interest; besides beng very graphic in description, it gives examples of personal and moral courage and of fightiug, such as brings back the remembrance of the fields of Cressy and Agincourt, for odds in the encounters.-AngloAmericon.

The history of the most thrilling incidents in the affairs of Texas, from the pen of the leading actor, and iu a style spirited, strong, and exciting. It will be read with great avidity.-Evening Post.

A volume of romantic interest ; it contains scenes and incidents connected with the well-known expedition, inrolving a bloody struggle, and gives us an insight into the character and conduct of men, which we read with no little interest.-Evangelist.

$\mathrm{XI}$.

\section{DARWIN'S VOYAGE ROUND THE WORLD.}

Journal of Researches into the Natural History and Geology of the Countries visited during the Voyage of H. M Ship Beagle round the World, under the Command of Capt Fitz Roy, R.N. By Charles Darwin, M.A., F.R.S. 2 vols. 12mo. Muslin gilt. $\$ 100$.

This is a first-rate work, combining popular interest with scientific ability and value, better than any similar book we have seen. It is written in a graceful and popular style,-Nero-York Courier and Enquirer.

XII.

\section{DR. MOTT'S TRAVELS IN EUROPE AND THE EAST,}

Travels in Europe and the East. By Valentine Mott, M.D. 8vo. Muslin gilt. \$1 90 .

The learned professor has judiciously abstained from the more common and familiar topics described by formcr tourists, and has introduced us to the most distinguished schools of medicine and surgery, and to a familiar acquaintance with the character, manners, \&c., of the most disting uished foreign unembers of the faculty. The author has evidently observed whatever came under his notice with a critical eye, and has given some new and striking views, particularly in regard to the Pythian Oracle, the Temple of Apollo at Delphis, and the religion of the ancient Egyptians. -Methodist Quarterly Review. 


\section{XIII.}

\section{LESTER'S GLORY AND SHAME OF ENGLAND.}

The Glory and Shame of England. By C. Edwards Lester. 2vols. 12mo. Engravings. Muslin gilt. \$1 50.

The bold and romantic spirit of this work has already procured it no small share of attention both in this country and Great Britain. The derelopments here made of the condition of the noor in England, making ciue allowance for the luxuriance of the author's fancy, are of a most fearful character. - Methodist Quarterly Review.

XIV.

\section{PARRY'S VOYAGES TO THE POLAR SEAS.}

Three Voyages for the Discovery of a Northwest Passage from the Atlantic to the Pacific, and Narrative of an Attempt to reach the North Pole. By Sir W. E. Parry, R.N. 2 vols. $18 \mathrm{mo}$. Portrait. Muslin gilt. 90 cents.

The history of these enterprises will be found exceedingly interesting ; much curious and valuable information is also given in relation to the dreary and inhospitable regions of northern Siberia, and the various tribes that inhabit them. -Methodist Quarterly Review.

$\mathrm{XV}$.

KENDALL'S SANTA FE EXPEDITION.

Narrative of the Texan Santa Fé Expedition, comprising a Description of a Tour through Texas, and across the great Southwestern Prairies, the Camanche and Caygüa Hunting-grounds, \&c. By George Wilkins Kendall. 2 vols. 12mo. Map and Engravings. New Edition. Muslin gilt. $\$ 250$.

It has seldom fallen to our lot to read a narrative of so interesting and touching incidents of travel as abound in these volumes; we were not prepared to find in them reading so very attractive, nor could we form any idea that such a narrative of toils and sufferings as are here detailed by the sufferer himself, would present so many points of instruction to the general reader.-Methodist Quarterly Review.

XVI.

\section{ANTHON'S PILGRIMAGE TO TREVES,}

A Pilgrimage to Treves, through the Valley of the Meuse and the Forest of Ardennes, in the Year 1844. By Charles Edward Anthon. 12mo. Muslin gilt. 75 cents.

This book is a modest, carefully-written narrative of facts, with few reflections, and those generally marked with good sense and proper feeling.- Buffalo Commercial Advertiser.

If this at'ractive volume possessed no other claim to attention, it has the charm of novelty about it, the author having chosen no beaten track for his route, although one of great interest. $-\mathbf{N}$. Y. Com. Advertiser. 
XVII.

MISS SEDGWICK'S LETTERS.

Letters from Abroad to Kindred at Home. By Miss C. M. Sedgwick. 2 vols. $12 \mathrm{mo}$. Muslin gilt. $\$ 190$.

Miss Sedgwick has far exceeded her predecessors; for they only described characters and scenes, while she has carried her researches into the parlours, nay, into the very pantries of private individuals. Miss Sedgwick occupies a high position in America, not merely as an ornament of its world of light literature, but as a moral teacher.-London Athenaum.

XVill.

\section{VOYAGES ROUND THE WORLD.}

Voyages round the World, from the Death of Captain Cook to the present Time; including Remarks on the Social Condition of the Inhabitants in the recently-discovered Countries; their Progress in the Arts; and more especially their Advancement in Religious Knowledge. 18mo. Muslin gilt. 45 cents.

This volume, containing the researches of the latest navigators, is admirably written, presenting in every page matter of the most interesting and valuable kind.-New-Orleans Eulletin

\section{XIX.}

STEPHENS'S CENTRAL AMERICA.

Incidents of Travel in Central America, Chiapas, and Yucatan. By John L. Stephens. 2 vols. 8vo. Map and 80 Engravings. Muslin gilt. $\$ 500$.

$$
\mathrm{xx} \text {. }
$$

STEPHENS'S YUCATAN.

Incidents of Travel in Yueatan. By John L. Stephens. 2 vols. 8 vo. 120 Engravings, from Drawings by F. Catherwood, Esq. Muslin gilt. $\$ 500$.

XXI.

STEPHENS'S TRAVELS IN EGYPT,

Incidents of Travel in Egypt, Arabia Petræa, and the Holy Land. By John L. Stephens. 2 vols. $12 \mathrm{mo}$. Engravings. Muslin gilt. $\$ 175$.

XXII.

STEPHENS'S TRAVELS IN GREECE.

Incidents of Travel in Greecc, Turkey, Russia, and Poland. By John L. Stephens. 2 vols, 12mo. Engravings. Muslin gilt. $\$ 175$. 
XXIII.

DR, FISK'S TRAVELS IN EUROPE.

Travels in Europe ; viz., in England, Ireland, Scotland, France, Italy, Switzerland, some Parts of Germany, and the Netherlands. By W. Fisk, D.D. 8vo. Engravings. Sheep extra. $\$ 325$.

XXIV.

DR. HUMPHREY'S TOUR.

Great Britain, France, and Belgium. A short Tour in 1835. By H. Humphrey, D.D. 2 vols. 12mo. Muslin gilt. $\$ 175$.

$\mathrm{XXV}$.

MRS, HAIGHT'S LETTERS FROM THE OLD WORLD,

Letters from the Old World. By Mrs. Haight. 2 vols. $12 \mathrm{mo}$. Muslin gilt. $\$ 175$.

\section{XXVI.}

KAY'S RESEARCHES IN CAFFRARIA.

Travels and Researches in Caffraria; describing the Character, Customs, and Moral Condition of the Tribes inhabiting that Portion of Southern Africa. By Stephen Kay. 12mo. Engravings. Muslin. 85 cents.

XXVII.

\section{LANDERS' TRAVELS TO THE NIGER.}

Journal of an Expedition to Explore the Course and Termination of the Niger. With a Narrative of a Voyage down that River to its Termination. By Richard and John Lander. 2 vols. $18 \mathrm{mo}$. Engravings. Muslin gilt. 90 cents.

\section{XXVIII.}

OWEN'S VOYAGES TO THE AFRICAN COAST.

Narrative of Voyages to explore the Shores of Africa, Arabia, and Madagascar; performed under the Direction of Captain W. F. W. Owen, R.N. 2 vols. 12mo. Muslin. $\$ 112 \frac{1}{2}$.

XXIX.

REYNOLDS'S VOYAGE OF THE FRIGATE POTOMAC.

Voyage of the United States Frigate Potomac, during the Circumnavigation of the Globe, in the Years 1831-1834. By James N. Reynolds. 8vo. Engravings. Muslin gilt. $\$ 325$. 
$\mathrm{XxX}$

CIRCUMNAVIGATION OF THE GLOBE.

An Historical Account of the Circumnavigation of the Globe, and of the Progress of Discovery in the Pacific Ocean, from the Voyage of Magellan to the Death of Cook. $18 \mathrm{mo}$. Engravings. Muslin gilt. 45 cents.

XXXI.

EMERSON'S LETTERS FROM THE FGEAN.

Letters from the Egean. By James Emerson. 8vo. 75 cents.

XXXII.

JACOBS'S ADVENTURES IN THE PACIFIC OCEAN.

Scenes, Incidents, and Adventures in the Pacific Ocean, or the Islands of the Australasian Seas, during the Cruise of the Clipper Margaret Oakley, under Captain Benjamin Morrell. By Thomas Jefferson Jacobs. 12mo. Muslin gilt. $\$ 125$.

XXIII.

ROBERTS'S EMBASSY TO SIAM, COCHIN-CHINA, \&C.

Embassy to the Eastern Courts of Siam, Cochin-China, and Muscat. By E. Roberts. 8vo. Muslin. \$1 75.

XXXIV.

TASISTRO'S RANDOM SHOTS AND SOUTHERN BREEZES.

Random Shots and Southern Breezes. By Louis Fitzgerald Tasistro. 2 vols. 12mo. Muslin. \$1 50.

XXXV.

MACKENZIE'S YEAR IN SPAIN.

A Year in Spain. By Alexander Slidell Mackenzie. 3 vols. 12mo. Muslin gilt. $\$ 225$.

XXXVI.

MACKENZIE'S SPAIN REVISITED.

Spain Revisited. By Alexander Slidell Mackenzie. 2 vols. $12 \mathrm{mo}$. Muslin gilt. $\$ 1 \% 5$.

XXXVII.

MACKENZIE'S AMERICAN IN ENGLAND.

The American in England. By Alexander Slidell Mackenzie. 2 vols. $12 \mathrm{mo}$. Muslin gilt. \$150. 


\section{IMPORTANT THEOLOGICAL WORKS \\ PUBBISHED BY}

IIAPER \& BROTHERS, NEW-YORE.

I.

MILMAN'S HISTORY OF CHRISTIANITY.

The History of Christianity, from the Birth of Christ to the Abolition of Paganism in the Roman Empire. By Rev. H. H. Milman. With Notes, \&c., by James Murdock, D.D. 8vo. Muslin gilt. $\$ 190$.

II.

MILMAN'S HISTORY OF THE JEWS.

History of the Jews. By Rev. H. H. Milman. 3 vols. $18 \mathrm{mo}$. Maps, \&c. Muslin gilt. \$1 20.

III.

PALEY'S EVIDENCES OF CHRISTIANITY.

A View of the Evidences of Christianity. By William Paley, D.D. $18 \mathrm{mo}$. Half bound. 38 cents.

IV.

PALEY'S NATURAL THEOLOGY.

Paley's Natural Theology. With Illustrative Notes, \&c. By Henry Lord Brougham, F.R.S., and Sir Charles Bell, F.R.S. To which are added, Preliminary Observations and Notes, by Alonzo Potter, D.D. 2 vols. $18 \mathrm{mo}$. Engravings. Muslin gilt. 90 cents.

$\mathrm{v}$.

MACLAINE'S MOSHEIM'S ECCLESIASTICAL HISTORY.

Ecclesiastical History, Ancient and Modern; in which the Rise, Progress, and Variations of Church Power are considered in their Connexion with the State of Learning and Philosophy, and the Political History of Europe during that Period. By J. L. Mosheim, D.D. Translated, with Notes, \&c., by Archibald Maclaine, D. D. A new Edition, continued to 1826 , by Charies Coote, LL.D. 2 vols. 8 vo. Sheep extra. $\$ 350$. 
VI.

MURDOCK'S EDITION OF MOSHEIM.

Mosheim's Institutes of Ecclesiastieal History, \&c. By James Murdoek, D.D. 3 vols. 8 vo. Sheep. $\$ 750$.

VII.

NEAL'S HISTORY OF THE PURITANS.

The History of the Puritans, or Protestant Nonconformists; from the Reformation in 1517 to the Revolution in 1688 : comprising an Account of their Principles, their Attempts for a farther Reformation in the Church, their Sufferings, and the Lives and Characters of their most eonsiderable Divines. By Daniel Neal, M.A. A new Edition, with very copious additional Notes, by Rev. J. O. Choules. 2 vols. 8vo. Portraits. Muslin gilt. $\$ 350$.

VIII.

JARVIS'S NEW CHRONOLOGICAL INTRODUCTION.

A Chronological Introduction to the History of the Church, being a new Inquiry into the True Dates of the Birth and Death of Christ, with a Harmony of the Gospels, \&c. By Rev. S. F. Jarvis, D.D. 1 vol. 8vo. Muslin extra. $\$ 300$.

\section{IX.}

TURNER'S SACRED HISTORY OF THE WORLD.

The Sacred History of the World, attempted to be pinilosophically considered, in a Series of Letters to a Son. By Sharon Turner, F.S.A. 3 vols. i 8 mo. Muslin gilt. \$1 35 .

$x$.

\section{HUNTER'S SACRED BIOGRAPHY.}

Sacred Biography; or, the History of the Patriarclis. To which is added, the History of Deborah, Ruth, and Hannah, and also the History of Jesus Christ. By Henry Hunter. 8vo. Muslin gilt. $\$ 175$.

XI.

WADDINGTON'S CHURCH HISTORY.

A History of the Church, from the Earliest Ages to the Reformation. By Rev. George Waddington, M.A. 8 vo. Muslin gilt. $\$ 175$. 
XII.

REV, ROBERT HALL'S WORKS.

The complete Works of Rev. Rohert Hall, A.M. With a brief Memoir of his Life, by Dr. Gregory, and Observations on his Character as a Preacher, by Rev. John Foster. Edited by Olinthus Gregory, LL.D., and Rev. Joseph Belcher. 4 vols. 8vo. Portrait. Sheep extra. \$600.

XII.

KEITH'S DEMONSTRATION.

Demonstration of the Truth of the Christian Religion. By Alexander Keith, D.D. 12mo. Engravings. Muslin gilt. $\$ 137 \frac{1}{2}$.

$\mathrm{X} 1 \mathrm{~V}$.

KEITH'S LAND OF ISRAEL.

The Land of Israel, according to the Covenant with Abraham, with Isaac, and with Jacob. By Alexander Keith, D.D. 12mo. Plates. Muslin gilt. \$1 25.

XV.

KEITH ON PROPHECY.

Evidence of the Truth of the Christian Religion, derived from the Literal Fulfilment of Prophecy. By Alexander Keith, D.D. $12 \mathrm{mo}$. Muslin. 60 cents.

XVI.

REV. WILLIAM JAY'S WORKS.

The complete Works of Rev. William Jay. Author's enlarged Edition, revised, comprising Morning and Evening Exercises, short Discourses for Family Reading, the Christian contemplated, selected Sermons, Lives of Winter, Clark, \&c. 3 vols. 8 vo. Sheep extra. $\$ 500$.

\section{xVIl.}

\section{PRIDEAUX'S CONNECTION.}

The Old and New Testaments connected, in the History of the Jews and neighbouring Nations, from the Declension of the Kingdoms of Judah and Israel to the Time of Christ. By Humphrey Prideaux, D.D. 2 vols. 8 vo. Maps and Engravings. Sheep extra. $\$ 375$. 
XVIII.

SAURIN'S SERMONS.

Sermons of Rev. James Saurin. A new Edition, witl additional Sermons. Revised and corrected by Rev. Samuei Burder, A.M. With a Preface by Rev. J. P. K. Henshaw, D.D. 2 vols. 8 vo. Portrait. Sheep extra. $\$ 375$.

XIX.

SUMMERFIELD'S SERMONS.

Sermons and Sketches of Sermons. By Rev. John Summerfield, A.M. With an Introduction, by Rev. Thomas E. Bond, M.D. 8vo. Muslin gilt. \$1 75.

XX.

BROWN'S BIBLE DICTIONARY.

A Dictionary of the Holy Bible. Containing an Account of the Persons, Places, \&c., mentioned in the Old and New 'Testaments. By Rev. John Brown. With a Life of the Author, and an Essay on the Evidences of Christianity. 8vo. Sheep extra. $\$ 175$.

\section{XXI.}

\section{LEWIS'S PLATONIC THEOLOGY.}

Plato against the Atheists; or, the Tenth Book of the Dialogue on Laws, accompanied with Notes, Critical and Philosophical, and extended Dissertations on the main Points of the Platonic Theology as compared with the Holy Scriptures. By Tayler Lewis, LL.D. 1 vol. $12 \mathrm{mo.}$ Muslin gilt. \$1 50 .

We earnestly recommerid this great work to every educated man in the country; it opens up a field of reflection almost entirely new.-Truc Sun.

One of the most remarkable works of the season, if not of the age.New York Courier and Enquirer.

\section{XXII.}

\section{SHUTTLEWORTH'S CONSISTENCY OF REVELATION.}

The Consistency of Revelation with Itself and with Human Reason. By Plilip Nicholas Shuttleworth. $18 \mathrm{mo}$. Muslin. 45 cents. 






2.0.

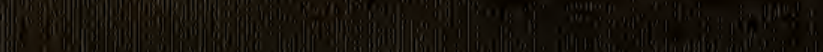
(1)

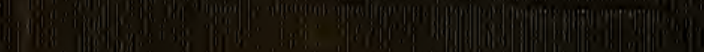

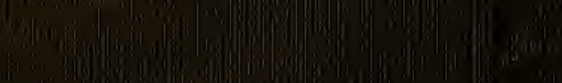
a. 